Collection of Research Papers in Conjunction with the $6^{\text {th }}$ International Scientific Conference of the Faculty of Law of the University of Latvia

\title{
Constitutional Values \\ in Contemporary \\ Legal Space II
}

16-17 November, 2016 
This publication presents the second collection of research papers in conjunction with the $6^{\text {th }}$ International Scientific Conference of the Faculty of Law of the University of Latvia "Constitutional Values in Contemporary Legal Space", Riga, 16-17 November, 2016, 294 pages.

Conference proceedings are supported by JSC "Latvijas Gāze”.

\section{GlatVisas Gäze}

Editorial Board for the Collection "Constitutional Values in Contemporary Legal Space II"

\section{Chair}

Prof. Dr. habil. iur. Kalvis Torgans, University of Latvia, Latvia

\section{Vice Chair}

Assist. Prof. Dr. iur. Vadim Mantrov, University of Latvia, Latvia

\section{Committee Members:}

Prof. Dr. iur. Carlo Amatucci, University of Naples Federico II, Italy

Prof. Dr. iur. Gracienne Lauwers, University of Antwerp, Belgium

Prof. Dr. iur. Jaap de Zwaan, Erasmus University Rotterdam, The Netherlands

Prof. Dr. iur. Arne Mavcic, European Law School, Slovenia

Prof. Tanel Kerikmae, Tallinn University of Technology, Estonia

Prof. Dr. iur. Peeter Jarvelaid, Tallinn University, Estonia

Prof. Dr. iur. Aleksei Kelli, Tartu University, Estonia

Prof. Dr. iur. Eivind Smith, University of Oslo, Norway

Prof. Dr. iur. Lali Papiashvili, Tbilisi State University, Georgia

Prof. Dr. iur. Ramunas Birstonas, Mykolas Romeris University, Lithuania

Prof. Dr. iur. Edita Gruodyte, Vytautas Magnus University, Lithuania

Assoc. Prof. Dr. iur. Timour Sysouev, Belarusian State University, Belarus

Assoc. Prof. Dr. iur. Vaidotas A. Vaicaitis, Vilnius University, Lithuania

Assoc. Prof. Dr. iur. Yanka Tyankova, University of Veliko Turnovo, Bulgaria

Assoc. Prof. Dr. iur. Krzysztof Prokop, Lomza State University of Applied Sciences, Poland

Postdoctoral Scholar Dr. iur. Begum Bulak, University of Geneva, Switzerland

Prof. Dr. iur. Janis Rozenfelds, University of Latvia, Latvia

Prof. Dr. iur. Kristine Strada-Rozenberga, University of Latvia, Latvia

Prof. Dr. iur. Daiga Rezevska, University of Latvia, Latvia

Prof. Dr. iur. Jautrite Briede, University of Latvia, Latvia

Prof. Dr. iur. Ringolds Balodis, University of Latvia, Latvia

Assoc. Guest Prof. Dr. iur. Christoph Schewe, University of Latvia, Latvia

Assoc. Prof. Dr. iur. Janis Karklins, University of Latvia, Latvia

Assoc. Prof. Dr. iur. Anita Rodina, University of Latvia, Latvia

Assoc. Prof. Dr. iur. Arturs Kucs, University of Latvia, Latvia

Assoc. Prof. Dr. iur. Kristine Dupate, University of Latvia, Latvia

Assist. Prof. Dr. iur. Janis Pleps, University of Latvia, Latvia

All contributions have been double-blind peer reviewed.

Layout: Andra Liepina

English language editor: Andra Damberga 


\section{Table of Contents}

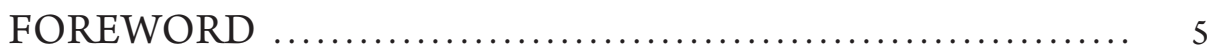

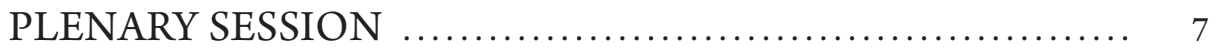

Jaap W. de Zwaan

The European Union in Crisis: Is There a Need

to Change Its Constitutional Structures? ......................... 7

Frank L. Schaefer

Human Dignity: Key Principle of the German Constitution? .............. 18

SECTION 1 ....................................... 29

Janis Lazdins

Aspects of the Denationalisation of Land Property in the Republic

of Latvia after the Restoration of Independence de facto ............... 30

\section{Eduards Bruno Deksnis}

The Legacy of Public Diplomacy by the Latvian Exile Community

During Restoration of Latvian Independence ...................... 43

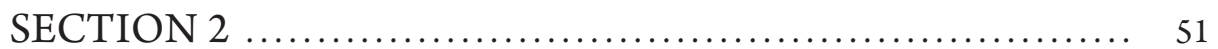

Lali Papiashvili

Modern Perspectives of Statutory Interpretation: In Search of

a New Paradigm for the Constitutional Adjudication in Georgia ............. 52

Daiga Rezevska

Ideology, Values, Legal Norms and Constitutional Court .............. 72

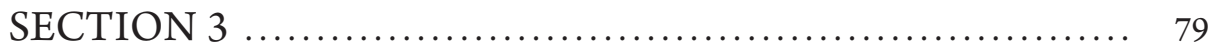

Andrejs Vilks

Legal Protection of Victims of Crime in the Context of

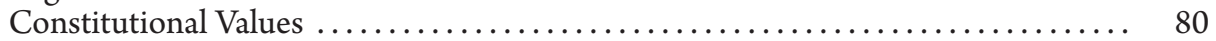

Julija Kolomijceva

Protection of the Right to Property of bona fide Persons Within

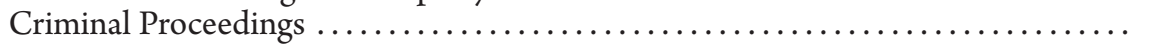

Jan Provaznik

Borders of the Landscape of Criminal Procedure Erected by the ECHR .

SECTION 4

Inga Kudinaviciute-Michailoviene, Ausra Maslauskaite

Enforcement of Parental Obligations: Legal and Sociological Aspects

of Contact and Maintenance Arrangements

Aleksei Kelli, Kadri Vider, Heiki Pisuke, Triin Siil

Constitutional Values as a Basis for the Limitation of Copyright Within

the Context of Digitalisation of the Estonian Language 


\section{Kalvis Torgans}

Fair Judgment in Civil Cases as a Manifestation of Implementing

Provisions of the Satversme

\section{Kaspars Balodis}

Case Law of the Constitutional Court and Private Law $\ldots \ldots \ldots \ldots \ldots \ldots \ldots . . \ldots$

\section{Carlo Amatucci}

Local Authorities, Credit Derivatives and Art. 117, 119

of the Italian Constitution

Inese Libina-Egnere

Property Rights, Expropriation of Real Estate for Public Needs, and Balancing of the Mortgage Creditor's and Real Estate Owner's Interests in the Process of Expropriation

\section{Eduardo Zampella}

Over-Indebtedness Crises Settlement Agreements and the Constitutional

Protection of the Rights of Citizens and Business Enterprises in Italy

SECTION 5

\section{Klara Drlickova}

Public Policy under the Article V(2)(b) of the New York Convention as an Instrument Protecting Constitutional Values

\section{Inga Kacevska}

Scrutiny of the Arbitration Law's Rules by the Constitutional Court

of the Republic of Latvia ..

\section{Arnis Buka, Lolita Berzina}

Application of the EU Directives in the Latvian Courts: Tendencies and Challenges

\section{Christoph Schewe}

Is the TTIP an Assault on the Rule of Law?

\section{Kristine Dupate}

The Impact of the International Law on the Concepts of 'Marriage' and 'Family' Under the Constitution of the Republic of Latvia and Obligation of Their Support and Protection

\section{Emese Szilagyi}

The Value of Political Equality - Comparing the Practices of the ECtHR and the Supreme Court of the United States ...

\section{Janis Grasis}

Compliance of the Latvian Personal Income Tax System to Preamble of the Satversme (Constitution) of the Republic of Latvia and International Obligations of the Republic of Latvia

SECTION 6

Edvins Danovskis

The Concept of Fault in Latvian Administrative Law

\section{Vadim Mantrov}

Regulation of recourse claim grounds in Latvian motor insurance law .. 


\section{Foreword}

The proposal to organise an international conference dedicated to constitutional values in contemporary legal space made by the Faculty of Law of the University of Latvia gained widespread support. The conference was held on November 16 and 17, 2016, involving legal scholars from 19 countries, whose presentations provided extensive insight into the impact of constitutional norms and principles upon rather ramified legal regulation of public life, as well as the existing contradictions and issues, and possible solutions to them. A part of the conference presentations has already been published in a sizeable printed edition in Latvian and English. ${ }^{1}$ This second electronic publication of conference materials in English comprises particularly selected presentations, recognised as significant by independent reviewers and the editorial board of this publication. These materials were not included in the first collection, and this collection will provide an opportunity for a broader circle of interested persons around the world to familiarize themselves with the presentations.

In the circumstances of globalisation, the number of legal acts in various fields of law is growing rapidly, the importance of international conventions, EU regulations and other supranational legal acts is constantly increasing. However, the constitution of each country still retains its stability as the basic law, which enshrines the most important rights, freedoms, principles, and safeguards their exercise. This causes conflicts, and, as repeatedly noted during the conference, constitutional courts that exist in many countries quite frequently have to deal with disputes regarding compliance of newly created or existing norms with the letter and the spirit of constitutions, as well as have to request a preliminary ruling on the particular issue from the Court of Justice of the European Union. Jurisdictional institutions have a number of possibilities: to recognise a statutory law as being incompatible with the constitution, to provide an interpretation of a constitutional norm, to interpret a contested statutory norm in a way that would not be incompatible with the constitution, to develop concepts on the impact of international law upon national law, to point to the need to amend the constitution, and to urge competent authorities to draft such amendments. In such cases, the state has an obligation to create new instruments and mechanism of legal protection.

We are living in turbulent times, when public order and security are threatened both by crime, which has become cross-border in its nature, as well as by terrorism

${ }^{1}$ Collection of Research Papers in Conjunction with the $6^{\text {th }}$ International Scientific Conference of the Faculty of Law of the University of Latvia "Constitutional Values in Contemporary Legal Space I”, Rīga, 16-17 November 2016. - University of Latvia Press, 2016, 640 p. 
and economic struggles, banking fraud and jolts in the financial system, intellectual property infringements, refugee problems. Society's perception of things that used to be treated unequivocally change, for example, marriage, family, protection of the rights of a child, and human dignity are viewed differently. A certain part of these developments is reflected in the articles of this collection, without claiming to provide the final resolution. However, one peculiarity should be noted. The majority of authors represent a narrower field of law and in their everyday work are not connected to issues and nuances of constitutional law, and, thus, are dealing with their problems from the relatively narrow perspective of laws that already exist or have to be drafted. Therefore, a benefit that the conference has brought both to the particular authors and to the legal science in general is the incentive given by the conference to seek solutions, keeping in mind constitutional norms and principles as guidelines on the way towards fair regulation of all legal issues. Experts of constitutional law, in turn, will become more aware of the diversity of elements within the contemporary legal space and of the necessity to improve and diversify the ways of embodying and protecting constitutional values.

The non-violent way in which Latvia, Lithuania, and Estonia regained their independence after 50 years of being incorporated in the USSR, using, inter alia, the doctrine of state continuity, has gained extensive global interest and recognition. On the basis of validity of 1922 Constitution of the Republic of Latvia that followed from this doctrine, the issue of citizenship was resolved in the state, immoveable property was denationalised, land reform was implemented, and other measures were taken. The Constitutional Court recently celebrated its $20^{\text {th }}$ anniversary. These processes are more extensively reflected in the aforementioned first collection of conference materials - Collection, Part I, as well as in other publications. Additionally, some articles (J. Lazdiňš, E. B. Deksnis, and K. Balodis) are also included in the current publication - Collection II.

I thank all the authors of articles included in this Collection for their contribution to successful conference proceedings.

Kalvis Torgans

Dr. habil. iur., Professor of the University of Latvia, Full member of the Latvian Academy of Sciences Riga, January 7, 2017 


\title{
PLENARY SESSION
}

Jaap W. de Zwaan, Dr. iur.

Erasmus University Rotterdam, The Netherlands

\section{THE EUROPEAN UNION IN CRISIS: IS THERE A NEED TO CHANGE ITS CONSTITUTIONAL STRUCTURES?}

\begin{abstract}
Summary
This contribution discusses the need for differentiated cooperation and simplification in the European Union as a response to several external and internal problems faced by the Union these days. In this light, several models for differentiation and simplification are proposed.

Keywords: European Union law and policy, general principles, unity and uniformity, threats and challenges, differentiated cooperation, enhanced cooperation, simplification, treaty amendment procedure.
\end{abstract}

\section{Introduction}

In light of the threats and challenges presently faced by the European Union (EU) both internally and externally, this contribution proposes a number of variants for differentiated cooperation to enable the EU to achieve its present treaty objectives on the one hand, and on the other, to allow the EU to advance further in the future. In order to apply these new ideas in practice, some fundamental constitutional principles in which the EU cooperation is presently based, have to be reconsidered. ${ }^{1}$

\footnotetext{
This contribution is based on a series of proposals developed by the author in a recent article about differentiation, flexibility and simplification of the overall European Union cooperation: Flexibility, Differentiation and Simplification in the European Union: Remedies for the Future? In: Governance and Security Issues of the European Union, Challenges ahead, De Zwaan J. W., Lak M., Makinwa A., Willems P. (eds.). Asser Press/Springer 2016. ISBN 978-94-6265-143-2, pp. 331-353.
} 


\section{Threats and challenges}

The EU has been a stable organisation for a long time. However, it is currently under a serious threat.

External challenges affect the stability and unity of the Union. To mention a few: the migration crisis, the tensions at our eastern boarders (Russia/Ukraine), the situation in Turkey, the continuing conflicts around the Mediterranean (Syria, Israel/Palestine, Libya) and terrorism. The maintenance of a good relationship with the United States should also be considered since Donald Trump has been elected as the $45^{\text {th }}$ President in November 2016.

The Union's cohesion is also challenged from the inside. The economic crisis is not yet over; several Member States are suffering disproportionally from the influx of migrants; populism is progressing in many Member States; governments of some Member States are involved in discussions about the violation of fundamental EU values and principles; and the citizens of the United Kingdom have voted in favour of a withdrawal of their Member State from the Union ('Brexit').

The discussions how to organize the EU's future agenda have started during the Summit meeting of the EU Heads of State and Government of 15 September 2016 in Bratislava. ${ }^{2}$

\section{Unity and uniformity as leading principles}

The European Union is supposed to act as an entity: every Member State participates in the process of policy making and decision making regarding given proposals. Once a decision has been taken, all Member States are bound to that same text and the implementation deadlines concerned.

Respect for the unity dogma has been justified from the outset by the necessity to build a common market: a common level playing field had to be established, in the context of which the same rules and principles - for example, with regard to mutual recognition and non-discrimination - had to be applied and enforced. An independent arbitrator - the European Commission - had to check the implementation of adopted decisions, and the rules had to be interpreted in a uniform manner by one exclusive authority, in our case, the Court of Justice in Luxembourg. ${ }^{3}$

Certainly, we have experienced deviations from those principles in practice. In a number of cases, for example, certain Member States have been granted derogations to participate in some policy domains:

- the United Kingdom and Denmark with regard to the Euro cooperation;

2 The United Kingdom's Prime Minister was not invited to attend that meeting.

3 The principle of uniform interpretation is embedded in the several elements of Article 267 of the Treaty on the Functioning of the European Union (TFEU). 
- the United Kingdom, Ireland and Denmark in relation to the Area of Freedom, Security and Justice cooperation; and, in that context

- the United Kingdom and Ireland with regard to the Schengen cooperation.

In other domains, specific conditions have to be fulfilled in order to be able to join a policy field, the Euro cooperation once more being an example.

The Amsterdam Treaty (entered into force in May 1999) introduced the principle of enhanced cooperation. ${ }^{4}$ This principle allows at least nine Member States to further the objectives of the Union, protect its interests and reinforce the integration process. ${ }^{5}$ It is a means of 'last resort', and can be triggered once it is established that the objectives of such cooperation cannot be attained within a reasonable period of time by the Union as a whole. ${ }^{6}$ Whereas the initial group can be considered as a sort of forerunner group, other Member States can join later. ${ }^{7}$

Nonetheless, unity and uniformity remain fundamental - not to say the most fundamental - principles of the EU cooperation.

\section{The need for more flexibility and differentiation}

However, in view of the threats and challenges referred to earlier, ${ }^{8}$ the question arises whether or not more flexibility is needed. This question deserves an answer in the affirmative.

Firstly, the number of Member States has increased significantly over the time. As such that is a great achievement. However, we have to recognize that the group of Member States is not that homogeneous anymore as it was in the early days. Furthermore, there are still a number of new members to come, such as the remaining successor states of the former Socialist Yugoslav Republic. In that respect, we must realize that important substantive differences do exist between these states and the present Member States, particularly with regard to their level of economic development. Secondly, the scope of EU objectives and competences has been substantially enlarged over the last decades. European cooperation started in the economic domain, with the internal market as its core business. Policies directly related to the working of the internal market, such as agriculture, transport and common commercial policy, were also included in the first version of the EEC Treaty. ${ }^{9}$ At a later stage - for example, when the European Single Act entered into force in July 1987 - domains like environmental policy and research were added to the list of European competences. Since the entry into force of the Maastricht Treaty in November 1993, crucial - but politically highly sensitive - complementary domains

\footnotetext{
See the present treaty texts: Article 20 TEU and Articles 326 to 334 TFEU.

Article 20(1), second sub-paragraph, of the Treaty on European Union (TEU).

Article 20(2) TEU.

Article 331(2) TFEU.

Supra, Paragraph 2.

The Treaty establishing the European Economic Community, entered into force on 1 January 1958.
} 
such as common foreign and security policy, as well as justice and home affairs belong to the responsibilities of the Union. In the economic domain, the Maastricht Treaty also introduced the concept of the Economic and Monetary Union, and other domains of policy, i.e., education, consumer protection and culture.

Thirdly, practice shows that not all Member States are prepared to cooperate in all policy domains they have signed up for. At any rate, it is becoming more and more difficult to come to common conclusions in quite a number of files. To mention a few: coordination - let alone approximation - of national economic policies, asylum and immigration.

A fourth reason, connected to the foregoing, is related to 'Euroscepticism': an increasing number of citizens believes that the integration process has advanced too fast, that its scope has become too wide, and that time has come to review the appropriateness to hand over more competences to the EU.

In its turn, 'Euroscepticism' has been given a new dimension by the activities of Eurosceptic political parties in Member States and, in relation to that tendency, by the emergence even of Eurosceptic governments in a number of Member States. Finally, since the outcome of the British referendum of 23 June 2016 we are confronted with 'Brexit', the situation of a Member State - the United Kingdom whose population prefers its country to withdraw from the Union.

Hence, it seems that there is a need to look for more options of flexibility and differentiation.

In that context, we should also refer to the fact - admittedly, a consideration of a different nature and characteristic than the earlier ones - that the European Union has its own interest to be enabled to achieve its present treaty objectives subscribed to by every single Member State, respectively, to develop further in future.

Therefore, two proposals will be put forward:

- The first one regarding the principle of enhanced cooperation;

- The second one concerns the procedure of treaty amendment.

\section{Enhanced cooperation}

As to the first proposal, time has come to revisit the appropriateness of the conditions for the application of enhanced cooperation. ${ }^{10}$

10 Regarding this discussion, and further materials, see also: De Zwaan J., Flexibility, Differentiation and Simplification in the European Union: Remedies for the Future? In: Governance and Security Issues of the European Union, Challenges ahead, already cited, pp. 338-341. Some recent contributions are: AIV (Advisory Council on International Affairs of the Dutch Minister of Foreign Affairs), Differentiated Integration: Different Routes to EU cooperation), No. 98, October 2015. Available at http://aiv-advies.nl/download/f8c9ecb6-798e-4a4c-856e-22005cf6d05d.pdf [last viewed March 8, 2017]; Kroll D. and Leuffen D., Enhanced cooperation in practise. An analysis of differentiated integration in EU secondary law, Journal of European Public Policy, 2015, Vol. 22. No. 3, pp. 353373; Piris J-Cl, The acceleration of differentiated integration and enhanced cooperation, Fondation 
Practice shows that the principle is difficult to apply. For example is an explicit mandate of the Council is required - to be decided upon by qualified majority, on a proposal from the Commission and with the consent of the European Parliament to allow the group of at least nine Member States to advance. ${ }^{11}$

Moreover, conditions have been set in the treaties to prevent the undermining of the working of the internal market as well as economic, social and territorial cohesion. Furthermore, enhanced cooperation must not constitute a barrier to or discrimination in trade between the Member States, nor shall it distort competition between them. ${ }^{12}$

Certainly, such conditions have been set for good reasons, namely, to avoid the core business of the EU being negatively affected by unilateral approaches of groups of individual Member States. Moreover, practising enhanced cooperation runs counter to the principles of unity and uniformity.

Be that as it may, since the entry into force of the relevant treaty provisions in May 1999, enhanced cooperation has been applied only three times, in the following domains: divorce law as a dimension of European family law, ${ }^{13}$ the European patent ${ }^{14}$ and the international financial tax. ${ }^{15}$

The question therefore arises, whether the procedural rules on how to apply enhanced cooperation, should not be simplified. For example, the requirement concerning an explicit approval of the Council could be replaced by the simple rule that enhanced cooperation can be started once a number of Member States representing a 'substantial' part of the EU population is willing to do so. In that respect, one could think of 'three quarter of the number of Member States' as a criterion, so in the present state of play 21 out of 28 Member States. In so doing, a substantive 'critical mass' of Member States supporting the amendments is ensured.

An important side effect of such a new scenario is that a blocking minority of Member States within the Council ${ }^{16}$ would not be able to prevent enhanced cooperation from being applied.

Another issue that has to be reviewed is related to the fact that, in order to apply enhanced cooperation, the Commission has to submit a formal proposal to

Robert Schuman/European Issues No. 328 of 13 October 2014, pp. 1-5; and Piris J.-Cl., The Future of Europe, Towards a Two-Speed EU, Cambridge University Press, 2012, ISBN 978-1-107-02137-2.

11 Articles 20(2) TEU, to be read in conjunction with Article 329(1) TFEU.

12 Article 326, second sub-paragraph, TFEU.

13 Council Regulation 1259/2010 of 20 December 2010 implementing enhanced cooperation in the area of the law applicable to divorce and legal separation, OJ L 343 of 29 December 2010, pp. 10-16.

14 Council Decision 2011/167 of 10 March 2011 authorising enhanced cooperation in the area of the creation of unitary patent protection, OJ L 76 of 22 March 2011, pp. 53-55.

15 Council Decision 2013/52 of 22 January 2013 authorising enhanced cooperation in the area of financial transaction tax, OJ L 22 of 25 January 2013, pp. 11-12.

16 Including at least four Council members, see the elements mentioned in Article 16(4), second subparagraph, TEU. 
the Council. ${ }^{17}$ In fact, this is a strange condition in a situation where the Commission in the earlier stage of the negotiations - already put a (policy) proposal on the table that, however, could not be adopted within a reasonable period of time because the required majority was lacking in the Council. ${ }^{18}$ Hence, and considering that enhanced cooperation essentially aims to further the objectives of the Union and to reinforce the integration process, ${ }^{19}$ a 'confirmation' by the Commission of an initiative taken by the group of Member States as a solution 'of last resort' ${ }^{20}$ should suffice. In this regard, the involvement of the Commission is clearly indicated in view of its mission to protect the general interest of the $\mathrm{EU}^{21}$

Therefore, the appropriate scenario could be that an initiative of a group of at least 21 Member States - tabled after a period of intensive negotiations in the Council without the (full) Council being able to come to an agreement - aiming to start enhanced cooperation only has to be 'confirmed' by the Commission. ${ }^{22}$

Finally, and as prescribed in the text of the Treaty on European Union as it stands, acts adopted in the framework of enhanced cooperation shall only bind the participating Member States. ${ }^{23}$ On the contrary, and unlike the situation at present, ${ }^{24}$ decisions adopted by applying the principle of enhanced cooperation should be regarded as part of the acquis to be accepted by future Member States. The main reason for such an alternative approach is that, as already mentioned, the principle of enhanced cooperation essentially aims to further the objectives of the Union, subscribed to and agreed to by all Member States.

To conclude, instead of raising obstacles in the process of implementation of the treaty objectives, we rather create opportunities to facilitate that process. Enhanced cooperation is an important instrument to further such a purpose.

17 Article 20(2) TEU, to be read in conjunction with Article 329(1) TFEU. In the last provision it is said, that in the event the Commission will not submit a proposal, it shall inform the Member States concerned of the reasons for not doing so.

18 This finding follows implicitly from the wording of Article 20(2) TEU.

19 Article 20(1), second sub-paragraph, TEU.

20 See, once more, the wording of Article 20(2) TEU.

21 See the reference to such a mission in Article 17(1) TEU.

22 Such new arrangements, once applied in practice, would have similar effects compared to some specific procedures in the Area of Freedom, Security and Justice context (Title V, Part Three, TFEU). Indeed, there it is said that, in case of disagreement in the Council and the European Council about certain files - all related to the areas of criminal law and police cooperation - the authorization to start enhance cooperation 'shall be deemed to be granted': see the Articles 82(3), 83(3), 86(1) and 87(3), TFEU.

23 Article 20(4), the first sentence, TEU.

24 Article 20(4), the second sentence, TEU. 


\section{Treaty amendment procedure}

The second proposal concerns the procedure for treaty amendment. ${ }^{25}$

The present rules and procedures for treaty amendment are embedded in Article 48 of the Treaty on European Union. Inherent to these rules and procedures is that all stages of the process are governed by the principle of consensus: the outcome of the negotiations has to be accepted by all Member States; the text of an agreement has to be signed by all Member States; and the agreement has to be approved, at national level, by the parliaments of all the Member States.

Therefore, in practice, each individual Member State possesses a right of veto in all stages mentioned. Since the EU cooperation is a gradual process, this means that each substantive new step not only has to be accompanied by treaty change but also has to be approved by all Member States, none excluded, alternative and lighter instruments not being available.

In the given circumstances the question arises whether possibilities for simplification should not be examined. Or, in other words, whether the principle that each individual Member State can veto new developments in the integration process should not be reconsidered.

At the present state of EU law, there are two existing variants of a so-called simplified revision procedure, both of them introduced by the Lisbon Treaty:

- Amendment of all or part of the provisions of Part Three TFEU relating to the internal policies and action of the Union. ${ }^{26}$ According to this procedure, it is up to the European Council to take a unanimous decision, after having consulted the European Parliament and the Commission; ${ }^{27}$

- Amendment of the modalities of decision making in a given area: from unanimity to qualified majority voting, and from the application of the 'special' legislative procedure to the 'ordinary' one. ${ }^{28}$ According to this - second procedure, the European Council can act by unanimity after having obtained the consent of the European Parliament.

Certainly, these options do represent progress, however, (only) with regard to treaty amendments of a relatively low importance. Moreover, the application of both procedures still requires a formal approval by all Member States before the amendments concerned can enter into force. Indeed, in case of amendments to Part III TFEU, the first option, an approval by all Member States has to be provided in accordance with their respective constitutional requirements, which in practice refers to approval by national parliaments. ${ }^{29}$ Once applying the second option,

25 Regarding this discussion, and further materials, see also: De Zwaan, J., Flexibility, Differentiation and Simplification in the European Union: Remedies for the Future? In: Governance and Security Issues of the European Union, Challenges Ahead, already cited, pp. 349-351.

26 Article 48(6) TEU.

27 Also the European Central Bank will be consulted in case of institutional changes in the monetary area: Article 48(6), second sub-paragraph, TEU.

28 Article 48(7) TEU.

29 Article 48(6), second sub-paragraph, TEU. 
related to institutional rearrangements, the amending decision has to be notified to national parliaments. In case (only) one national parliament makes known its opposition, the decision concerned cannot be adopted. ${ }^{30}$

Therefore, in order to bring Union cooperation really forward, a more far-reaching formula has to be considered. ${ }^{31}$

In that context, 'representative' groups of Member States should be allowed to start negotiations to amend existing treaty provisions and, once adopted and approved, to apply them in their mutual relations. In that respect, one can imagine that treaty amendments thus concluded should become binding once - as, by the way, has been proposed for the 'triggering' of the principle of enhanced cooperation ${ }^{32}$ - at least three quarter of the number of Member States has approved them. Again, that means in the present situation 21 out of $28 .{ }^{33}$

Equally - and that also would imply an important deviation of the present rules such treaty amendments should no longer be formally approved at national level by all 28 national parliaments. On the other hand, national parliaments should be entitled to reject the treaty amendments within a certain period - for instance, nine months - after the adoption of the texts concerned. At any rate, the treaty amendments would enter into force when (at least) 21 national parliaments do not object to the amendments.

Consequently, the Member State whose national parliament has objected to the amendments, shall not be bound thereby. Furthermore, such a Member State can always subscribe to the new treaty texts later.

Moreover, and that would be the logic of the new construction, the contents of the amendments adopted through the application of the simplified procedure should be regarded a part of the European Union acquis to be negotiated with candidate

30 Article 48(7), third sub-paragraph, TEU.

31 Also the former ECSC Treaty contained a formula for a simplified treaty amendment procedure: in Article 95, third and fourth sub-paragraph, ECSC it was stated that, when an adaptation of the rules for the Commission's exercise of its powers was felt necessary, appropriate amendments could be proposed jointly by the Commission and the Council, acting by twelve-fifteenths majority of its members. Such proposals had to be submitted to the Court for its opinion. Once the Court had ruled that the proposals were compatible with the conditions set, they were forwarded to the European Parliament and could enter into force if approved by a majority of three quarters of the votes cast and two thirds of the members of the Parliament.

32 Supra, Paragraph 5.

33 In a study of the Spinelli Group called "A Fundamental Law of the European Union", 2013. Verlag Bertelsmann Stiftung, Gütersloh, ISBN 978-3-86793-537-1, the possibility of amending the treaties without all Member States agreeing to it has also been dealt with. According to their proposal, no Member State is entitled to block a treaty amendment, whereas for the adoption of such an amendment a majority of three quarters of the Member States is required. According to the same proposal, a treaty amendment may enter into force once the ratification by four fifths of the number of Member States representing half of the overall population of the Union has been completed, or after having obtained a majority in a referendum held at the same time in all Member States: pp. 85 and 89-91. However, unlike the proposals in the present contribution, the Spinelli option allows for outvoting one or more Member States. Such an outcome is difficult to accept in the context of primary law amendments. Regarding the consequences of voting in the Council, see also below, Paragraph 8. 
Member States. That said, new Member States should not be obliged to respect such new obligations already at the outset of their membership. Like the present Member States not participating, they can 'opt in' once they are prepared and willing to do so. An important consequence of such an alternative scenario would be that individual Member States no longer possess a right to veto new developments, as the situation is now. On the other hand, because a non-willing Member State shall not be bound to such new reforms, it may be concluded that this new approach is legitimate and democratically justified.

\section{Stability and EU institutional framework}

In all this, we have to remember that the stability of the overall EU construction will not endangered by the non-participation of individual Member States in certain policy areas. The idea is also that, when applying models of differentiated cooperation, use will be made of the ordinary institutional framework of the Union. Consequently, the institutions can play their ordinary role, whereas the traditional decision making procedures remain of application.

Indeed, practising differentiated cooperation should not result in negative consequences for the characteristics, the quality and the coherence of the overall integration process.

In that context, individual Member States should not be allowed to escape from a set of fundamental obligations. To put it differently, a basic and solid framework of cooperation composed of crucial policies and principles must be respected by all Member States at all times. The internal market cooperation, traditionally looked at as the 'core business' of the European Union, is a first point of reference in that respect.

Also the values of peace and stability, that we have been able to enjoy for a long time on (the greatest part of) our European continent, should not be put in danger. Indeed, political stability and peace in Europe are served by the availability of substantive and disciplinary mechanisms assuring that vital issues having a cross-boundary effect are discussed and decided upon at the European level, at the negotiation table.

\section{Fundamental changes}

Certainly, the proposals regarding differentiation and simplification presented in this contribution are far-reaching and fundamental in nature. Are they justified, and are they appropriate?

Clearly, there may - and will - be different opinions in that respect. Moreover, in order to have the proposed changes accepted, they first have to be approved according to the ordinary procedure for treaty amendment. That means, by going through all stages and steps already mentioned and, more importantly, after being 
accepted, signed and approved by all Member States. ${ }^{34}$ This certainly is a difficult hurdle to overcome.

On the other hand, the perspective of the proposals made is a broad one: the interests of the European Union, the ambitions of 'willing' Member States, as well as the expectations of their citizens. How to enable the Union to achieve its treaty objectives, subscribed to by all of its Member States? And, with regard to our future cooperation, how to enable the Union to advance further by setting new goals? But, also, how to facilitate Member States - and their citizens - willing to go forward and to take new steps in the process of European integration?

All these questions deserve a clear but fair answer. In this light, it is also important to rethink the merits of fundamental 'constitutional' principles, such as unity and uniformity of the EU structures, in the interest of the overall EU cooperation itself. In this discussion, the idea is that it is better to develop forms of differentiated cooperation than to introduce more possibilities for (qualified) majority voting to be applied during the negotiations in the Council regarding (new stages of) common policies.

In this respect, it should be realized that once a vote has taken place in the Council, also the outvoted Member States will be bound by the decision concerned. There was a logic to apply such a principle in the earlier stages of the integration process. Here, again, and as recalled earlier, the establishment of the internal market can serve as the first example. Indeed, in order to achieve an area without internal frontiers, in which the free movement of goods, persons, services and capital is ensured, ${ }^{35}$ the application of principles like unity and uniformity was essential. However, since the process of integration presently covers practically all the policy domains and, by doing so, touches upon the roots of national society - think of politically sensitive areas like justice and home affairs, as well as foreign policy and defence - a more flexible approach is indicated.

Therefore, the Member States who do not want to be involved in new policy developments should better not be forced, by outvoting them in the ordinary decision-making process, to implement decisions which they do not actively support. Anyhow, no Member State will ultimately be bound against its will.

\section{Conclusions}

Models of flexibility should not replace the traditional principles of unity and uniformity. On the contrary, as a starting point, every Member State has to be allowed to join - and to participate in - all operational activities of the Union. However, to the extent that in individual files such an objective cannot be achieved, we have to be realistic. Hence, the idea presented in this contribution is to allow smaller groups of

34 Regarding the different steps, see: Article 48 (2-5) TEU.

35 See the definition in Article 26(2) TFEU. 
Member States to advance, whereas the others can join later, once they are ready and willing to do so.

Therefore, models of differentiated cooperation aim to make it easier for the Union and the Member States willing to participate in a continuous process of cooperation to achieve their objectives.

Due to the aforementioned reasons, models of flexibility are rather to be considered as positive tools to help the integration process to advance and proceed. The alternative being that the process can easily come to a standstill, a result that neither satisfies the interest of any Member State and its citizens nor the interest of the EU as a whole.

\section{BIBLIOGRAPHY}

\section{Literature}

1. AIV (Advisory Council on International Affairs of the Dutch Minister of Foreign Affairs), Differentiated Integration: Different Routes to EU cooperation), No. 98, October 2015. Available at http://aiv-advies.nl/download/f8c9ecb6-798e-4a4c-856e-22005cf6d05d.pdf [last viewed March 8, 2016].

2. De Zwaan J. W., Flexibility, Differentiation and Simplification in the European Union: Remedies for the Future? In: Governance and Security Issues of the European Union, Challenges Ahead. De Zwaan J. W., Lak M., Makinwa A., Willems P. (eds.). Asser Press/Springer 2016, ISBN 978-94-6265-143-2, pp. 331-353.

3. Kroll D. and Leuffen D., Enhanced cooperation in practise. An analysis of differentiated integration in EU secondary law, Journal of European Public Policy, 2015, Vol. 22. No. 3, pp. 353-373.

4. Piris J.-Cl. The Future of Europe, Towards a Two-Speed EU, Cambridge University Press, 2012, ISBN 978-1-107-02137-2

5. Piris J.-Cl. The acceleration of differentiated integration and enhanced cooperation, Foundation Robert Schuman/European Issues No. 328 of 13 October 2014, pp. 1-5.

6. Spinelli Group, A Fundamental Law of the European Union, 2013, Verlag Bertelsmann Stiftung, Gütersloh, ISBN 978-3-86793-537-1. 
Frank L. Schaefer, Dr. iur. LL.M. (Cambridge)

Institute for Legal History and Comparative Legal History,

Freiburg University, Germany

\title{
HUMAN DIGNITY: KEY PRINCIPLE OF THE GERMAN CONSTITUTION?
}

\begin{abstract}
Summary
The aim of this article is to challenge the German mainstream view on human dignity and to narrow the scope of application of human dignity. According to the established view, the principle of human dignity in Article 1 of the German Federal Constitution serves as an omnipotent formula, as some kind of magic wand. Politicians and the judiciary use the principle in an excessive manner to create new claims for social welfare and extensive access to the German welfare system for migrants from the European Union and beyond. To do so, they alter the nature of Article 1 from a principle to a concrete rule and even bypass European law to promote a political agenda, instead of adhering to the Constitution. The judiciary also mixes up the concept of human dignity with private autonomy, which is the fundamental principle of private law. This very wide understanding of human dignity shifts the power to create law from the Federal Parliament to the Federal Constitutional Court and other Federal Courts. In order to correct this unconstitutional development and to preserve freedom, one must cut back human dignity to its classic core, which is nothing more than a principle of last resort to prevent public infringement of basic rights.
\end{abstract}

Keywords: Constitution, human dignity, immigration, private autonomy, social welfare.

\section{Introduction: The Magic Wand}

For the German Federal Courts, the concept of human dignity is some kind of a deus ex machina. Whenever statutory law or constitutional basic rights fail to achieve the favoured result, human dignity in Article 1(1) of the Federal Constitution fills the gap and steps in to justify the verdict. ${ }^{1}$ The same is true for German politics. Whenever Federal Chancellor Angela Merkel tried to justify her immigration policy and the distribution of refugees throughout the European Union against reservations in Eastern Europe in late 2015 and early 2016, she relied on human dignity. ${ }^{2}$ Very much to the contrary, this study will challenge the mainstream view on human dignity in order to preserve the balance of power between parliament and the judiciary. It will rely on a broad set of perspectives (from history to philosophy)

1 See, for example Federal Constitutional Court, 9.2.2010 - 1 BvL 1, 3, 4/09, BVerfGE, Vol. 125, p. 175; 18.7.2012 - 1 BvL 10/10 and 2/11, BVerfGE, Vol. 132, p. 134, each on social welfare; Federal Constitutional Court, 29.5.1990 - 1 BvL 20, 26/84, 4/86, BVerfGE, Vol. 82, p. 60, on taxation.

2 See for example Exner U. "Menschenwürde endet nicht, wenn dieser Mensch kein Christ ist". WELT Online. 16 October 2015. Available at http://www.welt.de [last viewed September 1, 2016], during the debate between Merkel and Orbán; also Frenz W. Menschenwürde in der Flüchtlingskrise. ZAR, Vol. 2016, p. 223. 
to highlight the fact that the established view on human dignity is not a one-way road, but merely one of the possible ways of interpreting the Constitution. Therefore, the study chooses an interdisciplinary approach, which also includes the legal theory of private law.

Why is human dignity some kind of magic wand in Germany? One cannot blame the Federal Constitution itself for any pathetic or quasi-religious gesture. The official English translation of Article 1(1) simply reads, as follows: "Human dignity shall be inviolable. To respect and protect it shall be the duty of all state authority." ${ }^{3}$ The wording and system of the two sentences reveal some fundamental decisions with regard to human dignity, but other topics are left for the judiciary and legal scholarship to interpret and to develop. Sentence 1 lays down that human dignity has a special status. Since human dignity is ranked ahead of the following basic rights (Articles 2-19, Federal Constitution) and ahead of all other constitutional provisions, it is also clear that human dignity itself is no basic right, but somehow exists beside any basic right and any other constitutional provision. Therefore, the prohibition in Article 79(3) of the Federal Constitution (known as "eternity guarantee") to modify Article 1(1) has insofar only a descriptive function. Sentence 2 partially enlarges the protective range of human dignity. The word "respect" repeats the prohibition of any public intervention in Sentence 1. The word "protect" goes beyond Sentence 1 and establishes the public duty to actively protect human dignity. Other aspects of human dignity remain unsolved. The Federal Constitution neither hints at any philosophical foundation of human dignity, nor defines the concept of human dignity itself or its normative substance. Moreover, it remains an open question whether the state has the duty to perform social services for the sake of human dignity.

\section{Historical Dimension: Reaction to National Socialism}

The roots of human dignity in the Federal Constitution go back to ancient times and the Bible, but they do not contribute much to clarify the missing pieces of human dignity in Article 1(1). ${ }^{4}$ In classical antiquity, Cicero spoke about human dignity in the context of his fight against hedonism. ${ }^{5}$ The literature tries to read into Cicero the concept of equality between men, women and even slaves. ${ }^{6}$ In my

3 Official translation by Tomuschat C./Currie D. P. Available at http://www.gesetze-im-internet.de [last viewed September 1, 2016].

4 For the history: Dreier H. In: idem (ed.). Grundgesetz-Kommentar. Vol. 1. $3^{\text {rd }}$ edition. Mohr Siebeck: Tübingen, 2013, Article 1(1) recital 1 ff; Wetz F. J. Illusion Menschenwürde: Aufstieg und Fall eines Grundwerts. Klett-Cotta: Stuttgart, 2005.

5 Cicero M. T. De officiis, I 106; latest edition Newton B. P. (ed.). Marcus Tullius Cicero: On Duties (Agora Editions). Cornell University Press: Ithaca, 2016: "Ex quo intellegitur corporis voluptatem non satis esse dignam hominis praestantia eamque contemni et reici oportere, sin sit quispiam, qui aliquid tribuat voluptati, diligenter ei tenendum esse eius fruendae modum." See also D. 22.1.44 and D. 21.1.44.

6 Cancik H. "Dignity of Man" and "Persona" in Stoic Anthropology. Some Remarks on Cicero, de Officiis I 105-107 (2002). In: idem (ed.). Europa - Antike - Humanismus: Humanistische Versuche 
opinion, such an interpretation ignores the hierarchical understanding of society in ancient times. It would also be a misconception to interpret biblical passages such as Genesis $1: 27^{7}$ or Galatians 3:28 ${ }^{8}$ in the sense of modern human dignity. When Thomas Aquinas later distilled these passages into dignitas personae, ${ }^{9}$ he focused on the relationship between God and man, not on human dignity as a concept between men. The Catholic Church opposed human rights and therefore human dignity even in the $19^{\text {th }}$ century, when the German Empire fought its Kulturkampf..$^{10}$ The true foundation of human dignity lies in the Renaissance, when Giovanni Pico della Mirandola abandoned the concept that mankind mirrors God and turned to humanity's unique nature. ${ }^{11}$ Immanuel Kant's philosophy provided a further milestone in the age of enlightenment. Kant shaped the formula that no man shall use another man as a mere tool, but that every person must be valued for his or her inherent purpose. ${ }^{12}$

The modern constitutional movement adopted human dignity very late, despite its affinity to human rights. Neither the first wave of European constitutions (for example Poland, France) nor the later German constitutions (Confederation of the Rhine 1806, German Confederation 1815, Frankfurt 1849, German Empire 1871) implemented human dignity. The Weimar Constitution of 1919 mentioned the concept at least in order to frame the economy in Article 151(1): "The economy has to be organised based on the principles of justice, with the goal of achieving life in dignity for everyone." Attention shifted to human dignity when the resistance against National Socialism drafted plans for a post-war order for Germany. ${ }^{13}$ It is no exaggeration to state that the atrocities committed by the Nazi Regime assisted in the birth of human dignity as the apparent key principle of German constitutional

und Vorarbeiten. Transcript: Bielefeld, 2011, p. $327 \mathrm{ff}$.

7 New International Version - UK (NIVUK). Available at http://www.biblegateway.com [last viewed September 1, 2016]. "So God created mankind in his own image, in the image of God he created them; male and female he created them."

8 New International Version - UK (NIVUK). Available at http://www.biblegateway.com [last viewed September 1, 2016]. "There is neither Jew nor Gentile, neither slave nor free, nor is there male and female, for you are all one in Christ Jesus."

9 Aquinas T. Summa Theologiae, IIa-IIae q.63 arg.1; English translation by Gilby T. (ed.). Summa Theologiae. Blackfriars: Cambridge, 1964 ff.: "[...] In nomine enim personae intelligitur personae dignitas. Sed considerare dignitates personarum pertinet ad distributivam iustitiam $[\ldots]$ ”.

10 Pius IX., Syllabus errorum. 8 December 1864.

11 Pico della Mirandola G. De hominis dignitate. First edition 1496, with this title since 1557; English translation by Borghesi F. et. al. (eds.). Oration on the Dignity of Man: A New Translation and Commentary. Cambridge University Press: New York, 2012.

12 Kant I. Die Metaphysik der Sitten. Nicolovius: Königsberg, 1797, II $\$ \$ \$ 11,38$ (Academy-edition, Vol. 6, pp. 429, 433, 462 f.).

13 See Kreisau Circle. Memorandum "Grundlagen einer Außenpolitik für die Nachkriegszeit". In: Roon G. v. (ed.). Neuordnung im Widerstand: der Kreisauer Kreis innerhalb der deutschen Widerstandsbewegung. Oldenbourg: Munich, 1967, p. 551; Richtlinien für eine deutsche Staatsverfassung. In: Union Deutscher Sozialistischer Organisationen in Grossbritannien. Zur Politik deutscher Sozialisten: politische Kundgebungen und programmatische Richtlinien der Union Deutscher Sozialistischer Organisationen in Grossbritannien. Union Dt. Sozialistischer Organisationen in Grossbritannien: London, 1945, p. 5. 
law. ${ }^{14}$ Hence, the historical foundation of the specific German concept of human dignity is not very solid.

\section{Comparative Dimension: Plurality}

From a comparative perspective, human dignity is no singularity of the German Federal Constitution, but the principle has very different scopes of application. ${ }^{15}$ The specific German concept of human dignity is not some kind of natural law, but only one possibility amongst others.

Most constitutions of the German Federal States mention human dignity: BadenWürttemberg (Article 41(2) of the Baden Constitution of 1947; preamble of the Württemberg-Baden Constitution of 1946 and preamble of the BadenWürttemberg Constitution of 1953); Bavaria (preamble and Article 100, Constitution of 1946); Berlin (Article 6, Constitution of 1995); Brandenburg (preamble and Article 7, Constitution of 1992); Bremen (preamble, Articles 5(1), 26 No. 1 and 52(1), Constitution of 1947); Hesse (Articles 3, 27 and 30(1), Constitution 1946); Mecklenburg-West Pomerania (preamble, Articles 5(2), 7(2) and 56(3), Constitution of 1993); North Rhine-Westphalia (Articles 6(1), 7(1) and 25(2), Constitution of 1950); Saarland (Articles 1 and 47, Constitution of 1947); Saxony (Articles 14 and 117, Constitution of 1992); Saxony-Anhalt (preamble, Articles 4(1) and 10(3), Constitution of 1992) and Thuringia (preamble, Articles 1(1), 22(1) and 39(2), Constitution of 1993). The same is true for the East German Constitution of 1968 in Articles 4, 17(4), 19 and 90(1). The Bavarian Constitution in its original wording from 1946 provided the role model for the later Federal Constitution. Article 100 initially stated: "The dignity of human personality must be respected by legislature, administration and judiciary." In 2003, the Bavarian legislator changed Article 100 to the wording of human dignity in the Federal Constitution.

The overwhelming majority of member states of the European Union also relies on human dignity: the Kingdom of Belgium (Articles 23, Coordinated Constitution of 1994); the Republic of Bulgaria (preamble, Articles 4(2), 6(1) and 32(1), Constitution of 1991); the Czech Republic (preamble, Constitution of 1992); the Republic of Croatia (Articles 25(1) and 35, Constitution of 1990); the Republic of Estonia (Section 10, Constitution of 1992); the Republic of Finland (Articles 1(2), 7(2) and 9(4), Constitution of 1999); the Hellenic Republic (Articles 2(1), 7(2), 15(2) and 106(2), Constitution of 1975, amended in 2001); Hungary (preamble, Articles 2 and 37(4), Constitution of 2011); the Republic of Ireland (preamble, Constitution of 1937); the Italian Republic (Articles 3(1), 32(3) and 41(2), Constitution of 1947); the Republic of Latvia (preamble, Article 95, Constitution of 1922, as amended in 1998); the Republic of Lithuania (Article 21(2), Constitution

14 Dietrich D. J. Human Rights and the Catholic Tradition. Transaction Publishers: New Brunswick, London, 2007, p. 116.

15 Blömacher S. Die Menschenwürde als Prinzip des deutschen und europäischen Rechts: Kohärenz der Konzepte? Duncker und Humblot: Berlin, 2016; Dupré C. The Age of Dignity: Human Rights and Constitutionalism in Europe. Hart Publishing: Oxford, 2015. 
of 1992); the Republic of Poland (preamble and Article 30, Constitution of 1997); the Portuguese Republic (Articles 1, 13(1), 26(2) and (3), 67(2)(e), 206, Constitution of 1976); Romania (Articles 1(3), 30(6), Constitution of 1991); the Slovak Republic (Articles 19(1), Constitution of 1992); the Kingdom of Spain (Articles 10(1), Constitution of 1978) and the Kingdom of Sweden (Section 2(1), Constitution of 1974).

European law (Articles 2 of the Treaty on European Union of 2007 and Article 1 of the Charter of Fundamental Rights of the European Union) also implements human dignity. The same is true for codifications and treaties besides the European Union, if one looks at the Universal Declaration of Human Rights of 1948 (preamble, Articles 1, 22 and 23(3)) or at the present Swiss Federal Constitution of 1999 (Articles 7).

The normative dimension of human dignity varies substantially, leading to four different approaches. The first approach moves the concept on to the programmatic or metaphysical level, which rather addresses the public audience and politicians than judges. In Czechia, human dignity represents the constitutional spirit, in Greece it is a fundamental public duty, in Bulgaria - the "highest principle" and in Portugal and Spain, - the foundation of the state and the political order. Other constitutions have a written constitutional mandate to secure human dignity together with freedom and other values (for instance, in Germany, Baden-Württemberg, along with Finland, Ireland, Lithuania, Poland, Romania and Sweden), but without any detailed description for the legislation of how to implement it. The second approach implements human dignity in a different intensity as a justiciable basic right. The Polish Constitution grants human dignity the status of a source of all rights and every freedom, whereas Bavaria (since 2003), Berlin, Bremen, Brandenburg, Mecklenburg-West Pomerania, Saxony, Saxony-Anhalt, Thuringia and, outside of Germany, Hungary and, to a lesser extent, Switzerland, copy the German federal model. A less ambitious approach reduces human dignity to a basic right of personality (in Germany, North Rhine-Westphalia, formerly East Germany, along with Croatia, Lithuania, Portugal and Slovakia), to a basic right without higher value (Hesse, Saarland), or to a synonym for equality (the UN, Italy, Portugal and Slovakia). Human dignity is also utilised as a protection against public infringement of basic rights (in Germany, Thuringia, along with Croatia, Estonia, Finland, Greece, Italy and Romania). Finland, Greece, Latvia and Lithuania specifically use human dignity as a supplement to the prohibition of the death penalty and torture. Mecklenburg-West Pomerania and Saxony-Anhalt implement human dignity to restrict scientific research. The third approach uses human dignity to limit the private sector. Hesse, Saarland, Greece and Italy limit private business for the sake of human dignity. The fourth and last approach defines human dignity as a social right or social boundary for working conditions (in Germany, Baden, Berlin and Hesse, along with Belgium, Hungary and the UN). For instance, Article 23 of the Belgian Constitution grants all persons the right to a dignified life, but also demands statutory implementation and further diversification as the right to work, to choose the profession, as the right to social security and healthcare, adequate housing, clean environment and cultural and social development. 


\section{Philosophical Dimension: Rationality and Autonomy}

What is the correct concept for human dignity in the light of all the comparative relativity? Kant laid the foundation for a rational concept of human dignity, which is still the right approach for legal science and the judiciary today. Kant observed that one cannot verify the transcendental reality outside the mind, but has to rely on the logical form of the mind called faculty of reason or good sense. Kant's philosophy has three consequences for human dignity: first, human dignity must not appeal to God, social values or equity on the terminological level, but to the human reasoning in its legal formation, which can best be described as the inherent autonomy of human beings. Second, the concept of human dignity demands a rational application in its legal environment, it must submit to the same methodological standards as every other legal sentence. Third, the inner morality of human dignity consists of Kant's categorical imperative that no person should be used as a mere tool for another person's purpose.

This rational concept of human dignity is opposed to emotions and thus to rhetoric and politics. This became most obvious during the European crisis, where juridical, political and moral categories interpenetrate. When Alexis Tsipras, the Hellenic Prime Minister, said, "I will not ask Mr Schäuble for permission to hold a referendum. The dignity of a nation is not a game", ${ }^{16}$ he made a prudent political move. However, this dignity is far beyond the human dignity for constitutional and any other juridical purposes. When it comes to negotiating contracts and insisting on European law, the Hellenic Republic should cite democratic principles, the rule of law in European law and the basic principles of economic prudence.

\section{Normative and Methodological Dimension: A Critique}

If we follow the traditional approach, ${ }^{17}$ human dignity in Article 1(1) of the Federal Constitution influences legal application in two ways: first, it is at least a basic right or even a superior right above all other basic rights. Second, human dignity is used to interpret the basic rights in Articles 2 to 19 of the Federal Constitution, all other constitutional provisions and indirectly the statutory law. The first thesis misconceives the position of Article 1(1) in the constitutional system. Since human rights and specific German basic rights are only mentioned in the later sections of

16 Binswanger M. Endstation Irrenhaus. Griechenland beschwört die Würde. Das ist klug. In: Tagesanzeiger, 6 July 2015. Available at http://www.tagesanzeiger.ch [last viewed September 1, 2016].

17 Federal Constitutional Court, 13.6.1952 - 1 BvR 137/52, BVerfGE, Vol. 1, p. 332; Herdegen M. In: Maunz T., Dürig G. (founders) Grundgesetz: Kommentar. Beck: Munich, 2015, Article 1(1), recital 29; Höfling W. In: Sachs M. (ed.). Grundgesetz: Kommentar. $7^{\text {th }}$ edition. Beck: Munich, 2014, Article 1 recital 6 f.; Hofmann H. In: Schmidt-Bleibtreu B. et. al. (eds.). Kommentar zum Grundgesetz. 13 $3^{\text {th }}$ edition. Carl Heymanns: Cologne, 2014, Article 1 recital 8. - Critical Dreier H. In: idem (ed.). Grundgesetz-Kommentar. Vol. 1. $3^{\text {rd }}$ edition. Mohr Siebeck: Tübingen, 2013, Article 1(1), recital 42 f., 47 ff.; Enders C. In: Friauf K. H., Höfling W. (eds.). Berliner Kommentar zum Grundgesetz. Erich Schmidt: Berlin, 2005, Article 1 recital 68 ff. 
Article 1, human dignity in the first section of Article 1 is neither a simple right nor a basic right. Although Article 1(1) implements a duty to protect human dignity at first glance, the words "duty" and "respect" neither establish a normative binding rule nor an omnipresent principle to protect or to act. Consequently, the second thesis is also mistaken to a certain extent. It underestimates the constitutional content of the basic rights. The abolition of torture to save people's life or to extract a confession, for example, is already included in Article 2(2)(1) of the Federal Constitution, which protects life and health. Article 19(2) of the Federal Constitution blocks any infringement of the essence of all basic rights and thus torture in the light of Article 2(2) of the Federal Constitution. If somebody is already in custody, Article 104(1)(2) of the Federal Constitution even explicitly abolishes torture. The substantial core of these basic rights is independent of human dignity and needs no reference to human dignity. ${ }^{18}$ The Federal Constitutional Court approved this narrow interpretation of Article 19(2) when it decided that the legislature could completely abolish the right of asylum (Articles 16a of the Federal Constitution). ${ }^{19}$ If Article 19(2) defined the core of basic rights in the sense of human dignity, Article 79(3) of the Federal Constitution would exclude the parliamentarian power to abolish the right of asylum, since this provision shields human dignity against any legislative attack.

\section{Juridical Essence of Human Dignity: A Narrow Path}

Rather, human dignity establishes a mere programmatic principle and ethical foundation for the society, the state and the constitution itself. ${ }^{20}$ In other words, human dignity is closer to the non-binding content of the preamble than to binding constitutional norms or even rights. Its scope of application is limited to the systematic interpretation of other constitutional norms like basic rights and statutory law. Human dignity does not serve as an omnipotent argument during the process of interpretation, but as a last resort to rationality if other arguments are not properly considered. Thus, human dignity is more like a test for plausibility than an independent argument. To protect the balance of power, human dignity must shrink to a narrow Kantian definition as the inherent autonomy of human beings. What is called the "object formula" might serve as a test for an infringement of this autonomy: a person must not be degraded to an object, to a mere means, to a replaceable measurement. ${ }^{21}$ Insofar as human dignity is an absolute value, it is not open for any relativisation. Neither basic rights nor the human dignity of other

18 Dreier H. In: idem (ed.). Grundgesetz-Kommentar. Vol. 1. $3^{\text {rd }}$ edition. Mohr Siebeck: Tübingen, 2013, Article 1(1), recital 163.

19 Federal Constitutional Court, 14.5.1996 - 2 BvR 1938/93, 2 BvR 2315/93, BVerfGE, Vol. 94, p. 49.

20 Enders C. In: Friauf K. H., Höfling W. (eds.). Berliner Kommentar zum Grundgesetz. Erich Schmidt: Berlin, 2005, Article 1 recital $68 \mathrm{ff}$.

21 Federal Constitutional Court, 8.1.1959 - 1 BvR 396/55, BVerfGE, Vol. 9, p. 89 (criminal law); 15.2.2006 - 1 BvR 357/05, BVerfGE, Vol. 115, p. 118 (security); 8.11.2006 - 2 BvR 578, 796/02, BVerfGE, Vol. 117, p. 71 (lifelong sentence); developed by: Dürig G. In: Maunz T., idem (founders) Grundgesetz: Kommentar. Beck: Munich, 1958, Article 1(1), recital 28, 34. 
persons can override the object formula in any case. For instance, the state must not sacrifice one innocent person to save other persons.

\section{Non-Application in Public Law}

In public law, the judiciary refers to human dignity in cases like social law when the statutory law does not cover the preferred outcome. Article 1(1) of the Federal Constitution has become the incentive for a transformation of the German legal system, where not the Federal Parliament, but the Federal Constitutional Court sets the black letter rules for daily life. ${ }^{22}$ This is most obvious in the case of social law, when somebody claims welfare payments from social agencies. It is a longstanding tradition at the Federal Constitutional Court to justify such a claim through a combination of human dignity and the principle of the social welfare state, which is part of Article 20(1) of the Federal Constitution. ${ }^{23}$ The Court asserts that the legislature must guarantee a subsistence minimum that is in line with human dignity. The same line of argument comes into play to justify tax allowances to secure a minimum standard of life. ${ }^{24}$ Human dignity itself, not statutory law, is said to be the basis for the claim in social law, whereas the principle of the social welfare state demands that the legislature must enact the detailed provisions. The result is not a limited, but a universal entitlement, because the Federal Constitutional Court wants to grant social benefits irrespective of nationality. ${ }^{25}$ Subsequent to the decisions of the Federal Constitutional Court, the Federal Social Court ruled that every citizen of the European Union, who lives in Germany, can claim welfare payments. ${ }^{26}$ In essence, the Federal Social Court bypassed the decision of the European Court of Justice, which denied unemployment benefits (Hartz IV, Arbeitslosengeld II) to European citizens under certain conditions, ${ }^{27}$ since welfare payments are subsidiary to unemployment benefits. The Act to Regulate Claims of Foreign Persons in the Basic Support for Job Seekers, dated 22 December 2016, tries to correct this decision. It denies EU immigrants access to the German welfare system for the first five years if they had not worked in Germany before. If one takes the decision of the Federal Social Court seriously, the new restriction seems to infringe human dignity.

However, this extensive application of human dignity misjudges the normative scope of human dignity. Even if somebody lacks private assets, the inherent autonomy

22 See Rüthers B. Die heimliche Revolution vom Rechtsstaat zum Richterstaat. $2^{\text {nd }}$ edition. Mohr Siebeck: Tübingen, 2016.

${ }^{23}$ Federal Constitutional Court, 18.6.1975 - 1 BvL 4/74, BVerfGE, Vol. 40, p. 121 (pension); 21.6.1977 - 1 BvL 14/76, BVerfGE, Vol. 45, p. 187 (lifelong sentence); 7.6.2005 - 1 BvR 1508/96, BVerfGE, Vol. 113, p. 88 (maintenance); 9.2.2010 - 1 BvL 1, 3, 4/09, BVerfGE, Vol. 125, p. 175.

${ }^{24}$ Federal Constitutional Court, 29.5.1990 - 1 BvL 20, 26/84, 4/86, BVerfGE, Vol. 82, p. 60.

25 Federal Constitutional Court, 18.7.2012 - 1 BvL 10/10 and 2/11, BVerfGE, Vol. 132, p. 134.

${ }^{26}$ Federal Social Court, 3.12.2015 - B 4 AS 44/15 R, Neue Juristische Wochenschrift, Vol. 2016, p. 1464.

27 European Court of Justice, 25.2.2016 - C-299/14 (Jobcenter Recklinghausen/García-Nieto ua), Neue Juristische Wochenschrift, Vol. 2016, p. 1145. 
remains untouched at least in a formalistic sense. The wide application also destroys the established balance between judiciary and parliament. There is no case where human dignity could demand concrete administrative or legislative actions. This is true not only for social law, but also for other areas like immigration, where financial interests and security interests are at stake. The purpose of this limitation of human dignity is not to deny human rights, social welfare or immigration, but to rationalise the discussion, to break it down to concrete basic rights and to rebalance the separation of powers.

\section{Non-Application in Private Law}

In private law, human dignity has little room for application under the umbrella of the classic liberal model. The principle of private autonomy, which is part of the basic right of general freedom to act (allgemeine Handlungsfreiheit) in Article 2(1) of the Federal Constitution, replaces human dignity in private law, acting as an overarching, fundamental principle for more specific rights. ${ }^{28}$ Private autonomy is the individual power to act through the expression of free will. All other private rights (such as freedom of contract, freedom of property or freedom of succession) are nothing other than an application of this free will.

If we follow the jurisdiction of the German Supreme Courts, there still remain some fields of application for human dignity in private law, where private autonomy does not provide a sufficient normative base. The most important one is the general right of personality in tort law. The judiciary justifies this right through a combination of the general freedom to act (Articles 2(1)) and human dignity (Articles 1(1)). ${ }^{29}$ If one looks closer, any reference to human dignity is superfluous in this case. If one interprets the basic right of general freedom to act in a wide manner, it can include the general right of personality. Human dignity is even obsolete to defend the right of personality after a person's death, although the Federal Court of Justice only cites human dignity as the proper normative base for the post-mortal prolongation of the right of personality ${ }^{30}$ The argument that a deceased person cannot make any use of the general freedom to act, does not justify the denial of Article 2(1). In private law, the principle of universal succession demands that every person's right is transferred to the heirs after death. Since the very logic of succession law and the general system of property law precludes the separation of right and person, a right without a person is unthinkable. There is no reason to grant a deceased

28 See for the outstanding position of private autonomy: Drygala T. et al. (eds.). Private Autonomy in Germany and Poland and in the Common European Sales Law. Sellier: Munich, 2012; Ziegler K. S. Human Rights and Private Law: Privacy as Autonomy. Hart Publishing: Oxford, 2007.

29 Federal Constitutional Court, 14.2.1973 - 1 BvR 112/65, BVerfGE Vol. 34, p. 269 (Soraya); Federal Court of Justice, 25.5.1954 - I ZR 211/53, BGHZ Vol. 13, p. 334 (Schacht); for the literature: Bamberger H. G. In: idem, Roth H. (eds.). Beck'scher Online-Kommentar zum BGB, $40^{\text {th }}$ edition, Beck: Munich, 2016, section 12, recital $101 \mathrm{f}$.

30 Federal Court of Justice, 20.3.1968 - I ZR 44/66, BGHZ Vol. 50, p. 133 (Mephisto); 1.12 .1999 I ZR 49/97, BGHZ Vol. 143, p. 214 (Marlene Dietrich). 
person, through the sole reliance on human dignity, a stronger position than a living person, where human dignity is combined with Article 2(1). ${ }^{31}$ Certain limitations remain. For instance, the heirs merely act as some kind of trustees with regard to the newly acquired right of personality of another person. They also cannot claim compensation for pain and suffering if somebody infringes the deceased person's right of personality.

\section{Conclusions}

The mainstream view grants human dignity in Article 1(1) of the Federal Constitution the status of a key principle of German constitutional law. Human dignity acts as a replacement for other parts of the Constitution and all statutory law. This understanding of human dignity, however, exposes the legal system to enormous risks, since human dignity is used as some kind of magic wand to override every statutory decision. In order to prevent human dignity from dilution as a daily and equitable remedy to correct unsound decisions, the concept of human dignity demands a new and very narrow understanding, to prevent the most harmful public intervention in the private sphere: the state must not abuse its citizens as mere tools, but must respect their inherent autonomy. The traditional, very wide scope of human dignity should be abandoned. For example, human dignity does not command any unlimited access for immigrants to the German social welfare system, it also does not grant a specific entitlement. Human dignity also lacks the quality of a superior or basic right, it is a mere reminder of last resort. However, this conclusion shall not at all serve as an argument against social welfare or immigration. It is simply a warning that the decision should lie in the hands of the parliament and not in the hands of an omnipotent judiciary.

\section{BIBLIOGRAPHY}

\section{Literature}

1. Bamberger H. G., Roth H. (eds.). Beck'scher Online-Kommentar zum BGB, $40^{\text {th }}$ edition. Beck: Munich, 2016. Available at http://beck.de [last viewed September 1, 2016].

2. Binswanger M. Endstation Irrenhaus. Griechenland beschwört die Würde. Das ist klug, in: Tagesanzeiger. 6 July 2015. Available at www.tagesanzeiger.ch [last viewed September 1, 2016].

3. Blömacher S. Die Menschenwürde als Prinzip des deutschen und europäischen Rechts: Kohärenz der Konzepte? Duncker und Humblot: Berlin, 2016.

4. Borghesi F. et. al. (eds.). Oration on the Dignity of Man: A New Translation and Commentary. Cambridge University Press: New York, 2012.

31 Dreier H. In: idem (ed.). Grundgesetz-Kommentar. Vol. 1. $3^{\text {rd }}$ edition. Mohr Siebeck: Tübingen, 2013, Article 1(1), recital 76. 
5. Cancik H. "Dignity of Man" and "Persona" in Stoic Anthropology. Some Remarks on Cicero, de Officiis I 105-107 (2002). In: idem (ed.). Europa - Antike - Humanismus: Humanistische Versuche und Vorarbeiten. Transcript: Bielefeld, 2011, p. $327 \mathrm{ff}$.

6. Dietrich D. J. Human Rights and the Catholic Tradition. Transaction Publishers: New Brunswick, London, 2007.

7. Dreier H. (ed.). Grundgesetz-Kommentar. Vol. 1. $3^{\text {rd }}$ edition. Mohr Siebeck: Tübingen, 2013.

8. Drygala T. et al. (eds.). Private Autonomy in Germany and Poland and in the Common European Sales Law. De Gruyter: Berlin, 2012.

9. Dupré C. The Age of Dignity: Human Rights and Constitutionalism in Europe. Hart Publishing: Oxford, 2015.

10. Exner U. Menschenwürde endet nicht, wenn dieser Mensch kein Christ ist. WELT Online. 16 October 2015. Available at http://www.welt.de [last viewed September 1, 2016].

11. Frenz W. Menschenwürde in der Flüchtlingskrise. Zeitschrift für Ausländerrecht und Ausländerpolitik (ZAR), Vol. 2016, p. 223.

12. Friauf K. H., Höfling W. (eds.). Berliner Kommentar zum Grundgesetz, Erich Schmidt: Berlin, $2000 \mathrm{ff}$.

13. Gilby T. (ed.). Thomas Aquinas: Summa Theologiae. Blackfriars: Cambridge, $1964 \mathrm{ff}$.

14. Giovanni Pico della Mirandola, De hominis dignitate (Oratio Ioannis Pici Miran. Concordiae Comitis). 1496. In: Ioannis Pici Mirandulae Omnia Opera. Venice, 1498.

15. Kant I. Die Metaphysik der Sitten. Königsberg: Nicolovius, 1797.

16. Kreisau Circle. Memorandum “Grundlagen einer Außenpolitik für die Nachkriegszeit”. In: Roon G. v. (ed.). Neuordnung im Widerstand: der Kreisauer Kreis innerhalb der deutschen Widerstandsbewegung. Munich: Oldenbourg, 1967.

17. Newton B. P. (ed.). Marcus Tullius Cicero: On Duties (Agora Editions). Cornell University Press: Ithaca, 2016.

18. Rüthers B. Die heimliche Revolution vom Rechtsstaat zum Richterstaat. $2^{\text {nd }}$ edition. Mohr Siebeck: Tübingen, 2016.

19. Sachs M. (ed.). Grundgesetz: Kommentar. $7^{\text {th }}$ edition. Beck: Munich, 2014.

20. Sandoni L. (ed.). Il sillabo di Pio IX, Bologna 2012.

21. Schmidt-Bleibtreu B. et. al. (eds.). Kommentar zum Grundgesetz. $13^{\text {th }}$ edition. Carl Heymanns: Cologne, 2014.

22. Theodor M., Günter D. (founders). Grundgesetz: Kommentar. Munich: Beck, $1958 \mathrm{ff}$.

23. Union Deutscher Sozialistischer Organisationen in Grossbritannien (ed.). Zur Politik deutscher Sozialisten: politische Kundgebungen und programmatische Richtlinien der Union Deutscher Sozialistischer Organisationen in Grossbritannien. London: Union Dt. Sozialistischer Organisationen in Grossbritannien, 1945.

24. Wetz F. J. Illusion Menschenwürde: Aufstieg und Fall eines Grundwerts. Stuttgart: KlettCotta, 2005.

25. Ziegler K. S. Human Rights and Private Law: Privacy as Autonomy. Hart Publishing: Oxford, 2007. 


\section{SECTION 1}

EXPERIENCE, LESSONS AND INTERNATIONAL IMPORTANCE OF THE RESTORATION OF INDEPENDENT STATEHOOD OF THE REPUBLIC OF LATVIA. HISTORICAL, POLITICAL AND LEGAL ASPECTS 
Janis Lazdins, Dr. iur.

University of Latvia, Latvia

\title{
ASPECTS OF THE DENATIONALISATION OF LAND PROPERTY IN THE REPUBLIC OF LATVIA AFTER THE RESTORATION OF INDEPENDENCE DE FACTO
}

\begin{abstract}
Summary
In the Republic of Latvia, following de facto restoration of the state's independence, land property was denationalised with the aim of restoring historical justice in legal property relationships, which had been ignored during the years of Soviet power. All the former owners, irrespectively of their citizenship or place of residence, were recognised as eligible for restoring property rights. However, the property reform did not ignore the interests of the state and of a bona fide owner. Therefore many former owners had to accept compensation or allocation of another property of equal value. The author proposes the thesis that comprehensive restitution of the property right after 50 years of occupation is impossible.
\end{abstract}

Keywords: land reform, nationalization, denationalisation, property, legal principle, justice.

\section{Introduction}

On 17 June 1940 the USSR occupied the Republic of Latvia. At the moment of occupation two different economic systems existed in these countries - market economy, which recognised a person's right to private property, in Latvia; and the planned economy, based upon foundations of collective (socialist) property, in the Soviet Union. Pursuant to Marxist-Leninist ideology, in the Soviet state the means of production could only be an object of collective property. ${ }^{1}$ The Constitution (Basic Law) of the Latvian Soviet Socialist Republic of 25 August 1940 provided:

"The land, its resources, waters, forests, large factories and plants, mines, pits, rail, water and air transport, banks, means of communications, state organised large agricultural enterprises (state farms, machine and tractor stations and the like), as well as municipal enterprises and large houses in cities and industrial localities are state property, i.e., belong to all people." 2

Nationalisation of property owned by residents of the occupied country, implemented by the USSR, was extremely unjust. Prof. Gustav Radbruch in such

Markss K., Engelss F. Komunistiskās partijas manifests [The Manifesto of the Communist Party]. [S.l.]: Zvaigzne ABC, 2008, p. 26; L,eninins V. I. Valsts un revolūcija [State and Revolution]. [S.1]: Zvaigzne ABC, [no date], pp. 110-114.

2 Latvijas Padomju Sociālistiskās Republikas Konstitūcija (Pamatlikums) [Constitution of the Latvian Soviet Socialist Republic (Basic Law)] (25.08.1940): Law of the Latvian SSR. Valdïbas Vēstnesis, 1940, No. 194, Art. 6. 
a case refers to legal injustice (delict) (gesetzliches Unrecht ${ }^{3}$ ). The famous "Radbruch Formula" demands that such unjust laws retreat in front of the principle of justice. ${ }^{4}$ On 4 May 1990 the Republic of Latvia restored its independence de facto. ${ }^{5}$ This ended the occupation of the Latvian State, which had lasted for almost 50 years. Obligations of Latvia as a state governed by the rule of law comprise respect for fundamental human rights, inter alia, protecting the right to property, i.e., also restoring the illegally deprived right to property. Therefore, after regaining sovereign power over its land and people, one of the first obligations for Latvia was denationalisation of property nationalised by the Soviet power. ${ }^{6}$ Regretfully, within the scope of one article it is impossible to examine all the aspects linked to denationalisation of land property. Consequently, the problems of restituting the property rights of religious organisations, corporations and Baltic Germans remain outside the scope of the author's research. Analysis of general objectives linked to land reform, identification of principles of law connected to this process, as well as providing an overview of issues in restoring title to land have been set as the aims of this article.

\section{Aims and general principles of land denationalisation}

The policy guidelines for reforming state property were defined by Decision of 20 March 1991 of the Supreme Council of the Republic of Latvia the (hereinafter also - RL SC) "On State Property and Basic Principles of Its Conversion". Conversion of state property comprised:

1) transferring state enterprises into the local government ownership;

2) denationalisation of state and local government enterprises;

3) privatisation of state and local government property. ${ }^{8}$

Thus, denationalisation of property was a part of economic policy implemented by the State with the aim of transiting from the socialist planned economy to

3 Kleinheyer G., Schröder J. (Hrsg.). Deutsche und Europäische Juristen aus neuen Jahrhunderten. Eine biographische Einführung in die Geschichte der Rechtswissenschaft. 5., neu bearbeitete und erweiterte Auflage. Heidelberg: C. F. Müller Verlag, 2008, pp. 356, 357.

4 Rüthers B., Fischer Ch. Rechtstheorie. Begriff, Geltung und Anwendung des Rechts. 5., überarbeitete Auflage. München: Verlag C. H. Beck, 2010, p. 597.

5 Deklarācija par Latvijas Republikas neatkarïbas atjaunošanu [Declaration of the restoration of independence of the Republik of Latvia] (04.05.1990): Law of the Republic of Latvia (hereafter RL). Available at http://likumi.lv/doc.php?id=75539 [last viewed May 17, 2016].

6 Lazdiņš J. Īpašums kā vērtỉba. İpašuma denacionalizācija. / Property as value. Denationalization of state property. Tiesību efektivitāte postmodernā sabiedrībā. LU 73. konferences rakstu krājums [Effectiveness of Law in Post-modern Society. Conference Papers of the $73^{\text {rd }}$ Conference of the University of Latvia]. [S.1.]: Latvijas Universitāte, 2015, p. 357.

7 Par valsts īpašuma un tā konversijas pamatprincipiem [On State Property and Basic Principles of Its Conversion] (20.03.1991): Decision of RL. Available at http://likumi.lv/doc.php?id=65829 [last viewed September 29, 2015].

8 On State Property and Basic Principles of Its Conversion, Art. 1. 
market economy, trying to restore historical justice in legal property relationships. ${ }^{9}$ Therefore, the decision "On State Property and Basic Principles of Its Conversion" provided:

"to recognise as being invalid those legal and public administration acts, on the basis of which starting with 17 June 1940 nationalisation of property and other unfounded alienation of property was conducted". ${ }^{10}$

In accordance with the principle of justice and equality, a number of significant basic principles were integrated into legal acts linked to denationalisation of property. Their aim was to restore the property relationships that had existed prior to the Soviet occupation as fully as possible:

1) to protect the rights of former owners and their heirs ${ }^{11}$ (hereinafter - former owners), denationalisation of property and privatisation with regard to the same objects of property did not happen simultaneously. This meant that, first of all, the claims for property denationalisation had to be collected. Only afterwards, taking into consideration the interests of the State and local governments, the remaining properties could be transferred for general privatisation. This was a clear sign that denationalisation of property was a priority vis-à-vis general privatisation; ${ }^{12}$

2) restitution of property rights was not linked to former owners' citizenship or place of residence. ${ }^{13}$ This meant that neither the fact that former owners lacked the citizenship of Latvia, nor that they resided outside the Republic of Latvia could become an obstacle for restitution of property rights.

Denationalisation of property could not become an obstacle to general privatisation. Therefore, former owners were given a short period to apply for submitting applications regarding denationalisation of nationalised land properties. Formally, the State acted correctly. In fact, in the name of economic reforms the process of denationalisation was unfoundedly hurried. Thus, the law of 21 November 1990

9 1991. gada 29. maija sēdes stenogramma (rïta sēde) [Transcript of the sitting of 29 May 1991 (morning session)]. Available at http://saeima.lv/steno/AP_steno/1991/st_910529.htm [last viewed June 2, 2016].

10 On State Property and Basic Principles of Its Conversion, Art. 3.1.

11 Par agrāro reformu Latvijas Republikā [On Land Reform in the Republic of Latvia] (13.06.1990): Decision of RL, Art. 3. Available at http://likumi.lv/doc.php?id=76206 [last viewed September 29, 2015]; On State Property and Basic Principles of Its Conversion, Art. 5.4.

12 Grūtups A., Krastinš E. İpašuma reforma Latvijā [Property Reform in Latvia]. Rīga: Mans īpašums, 1995, p. 132.

13 See, for example:

1. On State Property and Basic Principles of Its Conversion, Art. 5.3;

2. Par namīpašumu atdošanu likumīgajiem īpašniekiem [On Return of Building Properties to Rightful Owners] (30.10.1991): Law of RL, Art. 1. Available at http://likumi.lv/doc.php?id=70828 [last viewed May 15, 2016];

3. Par zemes privatizāciju lauku apvidos [On Land Privatisation in Rural Areas] (09.07.1992): Law of RL, Art. 5. Available at http://likumi.lv/doc.php?id=74241 [last viewed May 15, 2016 ]. 
"On Land Reform in the Rural Areas of the Republic of Latvia"14 and the law of 20 November 1991 "On Land Reform in the Republic of Latvia Cities"15 gave mere seven months to former owners to apply for recovery of property. However, a norm, to be unequivocally assessed, was incorporated in the law on land reform in cities, which, essentially, was contrary to the strict term for applying for restitution of property rights that had been established. If the former land owner had not submitted an application on denationalisation, but reliable information existed regarding the existence thereof, such a land plot could be transferred only for lease or use for 10 years. Fortunately, already on 1 June 1994 a new regulation entered into force. From then on in case of missing the term of application, the property right could be restored in court, if the land had been legally transferred into disposal of another person. ${ }^{16}$ Otherwise, missing this term meant losing priority regarding denationalisation of the nationalised property.

Thus, the concept of State property conversion, well-intended per se, in its implementation caused unnecessary tension in society. The fact that the circle of subjects of denationalisation with regard to land properties was expanded a number of times, as described below, did not facilitate trust in the reform policy of the State.

\section{Denationalisation of land and related problems}

Before the basic principles for conversion of State property entered into force, separate regulatory enactments were elaborated, which envisaged denationalisation of land property. Decision of 13 June 1990 by RL SC "On Agrarian Reform of the Republic of Latvia" became a certain point of reference. ${ }^{17}$ It is noted in the Preamble to the Decision that "the forced collectivisation of the agriculture of the republic was an error, both from the political and legal, as well as economic point of view, and the methods for implementing collectivization - illegal”. By entering into force this regulatory enactment marked the beginning of reforms in economic relations, envisaging restitution of the right to private ownership of land in the procedure set out in law. ${ }^{18}$ The author holds that the words uttered by Pèteris Simsons, member of RL SC, explain the need for denationalisation of property better than regulatory enactments do, - " $[\mathrm{w}]$ e wanted to restore our State. [.. the only principle being -

14 Par zemes reformu Latvijas Republikas lauku apvidos [On Land Reform in the Rural Areas of the Republic of Latvia] (21.11.1990): Law of RL. Available at http://likumi.lv/doc.php?id=72849 [last viewed May 20, 2016].

15 Par zemes reformu Latvijas Republikas pilsētās [On Land Reform in the Republic of Latvia Cities] (20.11.1991): Law of RL. Available at http://likumi.lv/doc.php?id=70467 [last viewed May 20, 2016].

16 Grozijumi likumā "Par zemes reformu Latvijas Republikas pilsētās" [Amendments to the Law "On Land Reform in the Republic of Latvia Cities"] (31.03.1994): Law of RL. Available at http://likumi. $\mathrm{lv} / \mathrm{ta} / \mathrm{id} / 58064$-grozijumi-likuma-par-zemes-reformu-latvijas-republikas-pilsetas- [last viewed May 26, 2016].

17 Par agrāro reformu Latvijas Republikā [On Land Reform in the Republic of Latvia] (13.06.1990): Decision of RL. Available at http://likumi.lv/doc.php?id=76206 [last viewed 29.09.2015].

18 On Land Reform in the Republic of Latvia, Art. 3. 
each of us has his own land, and we all together have our own State ${ }^{19}[\ldots]$ the land does not only have a material value. The land of our ancestors carries spiritual value, too. And, apparently, only those, who have been deprived of their ancestors' land, are able to understand it."20

The restitution of the right to "the land of fathers" was mainly based upon four laws:

1) “On Land Reform in the Rural Areas of the Republic of Latvia” (21.11.1990);

2) "On Land Use and Land Survey" (21.06.1991); ; $^{21}$

2) "On Land Reform in the Republic of Latvia Cities" (20.11.1991);

3) "On Land Privatisation in Rural Areas" (09.07.1992).

Those persons, who had owned immoveable property on 21 July 1940, ${ }^{22}$ i.e., a day prior to the one, when the so-called "People's Saeima" adopted "Declaration on Proclaiming Land to be Property of the People", ${ }^{23}$ were recognised as former owners. Proclaiming land to be the property of the people meant its nationalisation. The selected point of reference -21 July - for restoring property rights initially appeared to be legally substantiated. However, as it turned out later, it was not always correct. During World War II, the German occupation power reinstated the Latvian Civil Law of 28 January 1937 (hereinafter - the Civil Law). ${ }^{24}$ Properties were purchased and sold (1941-1945). However, not all new owners could be considered as being bona fide. Nazis, inter alia, were selling property belonging to persons that were undesirable (ideologically or otherwise) for the regime. ${ }^{25}$ The buyers of such properties could not be considered as being bona fide buyers in the meaning of the Civil Law. So there were full grounds for denying the former owners, who had become such in bad faith, the right to claim restitution of property rights through

19 1991. gada 29. maija sēdes stenogramma (vakara sēde) [Transcript of the sitting of 29 May 1991 (evening session)]. Available at http://saeima.lv/steno/AP_steno/1991/st_910529v.htm [last viewed June 1, 2016].

20 1992. gada 10. jūnija stenogramma (vakara sēde) [Transcript of 10 June 1992 (evening session)]. Available at http://saeima.lv/steno/AP_steno/1992/st_920610v.htm [last viewed June 1, 2016].

21 Par zemes lietošanu un zemes ierīcību (21.06.1991) [Ōn Land Use and Land Survey] (pamata redakcija) [initial wording]: LR likums. Available at: http://nais.lv/vtext.cfm?Key=0127011991062 $13277320050 \&$ idv $=45485$ [last viewed June 2, 2016].

22 On Land Privatisation in Rural Areas, Art. 2.1.1., 3.1., 5; On Land Reform in the Republic of Latvia Cities, Art. 4.4.

23 Deklarācija par zemes pasludināšanu tautas īpašumā [Declaration on Proclaiming Land to be Property of the People] (22.07.1940): Declaration of the Latvian SSR. Valdibas Vèstnesis, 1940, No. 167.

24 Par Latvijas ǵenerālapgabalā spēkā esošām tiesībām un par rīcību ar spriedumiem un lēmumiem [On the Law Valid in Province General of Latvia and Handling of Judgements and Decisions] (13.06.1942): Rules of the German Occupation Power. Rikojumu Vēstnesis, 1942, No. 124.

25 Grūtups A. Tiesu prakse un komentāri [Case Law and Commentaries]. Rīga: Mans īpašums, 1994, p. 125 . 
denationalisation. ${ }^{26}$ Likewise, the first year of the Soviet power (1940-1941), before the German army entered Latvia, from the point of view of legality of civil law turnover of property, cannot be given an unequivocal interpretation. Thus, for example, the Civil Law remained in force until 26 November 1940, when the Civil Code of the Russian Soviet Federative Socialist Republic entered into force. ${ }^{27}$ Therefore those persons, who had acquired property rights through transaction in the period from 22 July 1940 until 8 May 1945, had to turn to court to establish, whether the particular transaction complied with the Civil Law requirements. ${ }^{28}$

Expanding the circle of heirs turned into another problem already during implementation of the land reform. Denationalisation of land in rural regions was launched in accordance with the Civil Code of the Latvian Soviet Socialist Republic of 27 December $1963 .{ }^{29}$ The Soviet inheritance law complied neither with the traditional understanding of continental Europe of importance in consanguinity in inheritance, nor requirements of market economy. ${ }^{30}$ Pursuant to the Soviet law, only the closest relatives were recognised as heirs.

On 1 September 1992 the Parts of Property Law and Inheritance Law of the Civil Law were reinstated. ${ }^{31}$ The Civil Law, similarly to its more significant source - Part III of Collection of Local Laws of the Baltic Provinces, ${ }^{32}$ was drafted in the spirit of pandect doctrine of the German historical school of the Romano-Germanic legal

26 Lazdinš̌ J. (eds.), Kučs A., Pleps J., Kusiņš G. Latvijas valsts tiesību avoti. Valsts dibināšana neatkarïbas atjaunošana. Dokumenti un komentāri [Sources of Law of the Latvian State. Establishment of the State - Restoration of Independence. Documents and Commentaries]. Riga: Tiesu Namu Aǵentūra, 2015, p. 431.

27 Par KPFSR likumu (kodeksu) piemērošanu Latvijas PSR teritorijā [On Application of the Laws (Codes) of the Russian SFSR on the Territory of the Latvian SSR] (25.11.1940): Announcement by the Council of People's Commissars of the Latvian SSR. Latvijas PSR Augstākās Padomes Prezidija Ziñotājs, 1940, No. 74.

28 Amendments to the Law "On Land Reform in the Republic of Latvia Cities"] (31.03.1994), Art. 16; Grūtups A. Tiesu prakse un komentāri ..., pp. 124-125.

29 Latvijas Padomju Sociālistiskās Republikas Civilkodekss [The Civil Code of the Latvian Soviet Socialist Republic] (27.12.1963): Law of the Latvian SSR. Latvijas Padomju Sociālistiskās Republikas Augstākās Padomes un Valdības Ziṇotājs, 1964, No. 1.

30 Grasmann G., David R. [u. and.]. Einführung in die großen Rechtssysteme der Gegenwart. 2. deutsche Auflage. München: C. H. Beck'sche Verlagsbuchhandlung, 1988, p. 340; Luts-Sootak M., Osipova S., Schäfer Fr.L. (Hrsg./eds.). Einheit und Vielfalt in der Rechtsgeschichte im Ostseeraum. Sechster Rechtshistorikertag im Ostseeraum, 3.-5. Juni 2010 Tartu (Estland) / Riga (Lettland). Frankfurt am Main, Berlin, Bern, Bruxelles, New York, Oxford, Wien: Peter Lang: Internationaler Verlag der Wissenschaften, 2012, Bd. 428, pp. 123-133.

31 Par atjaunotā Latvijas Republikas 1937. gada Civillikuma ievada, mantojuma tiesību un lietu tiesību daļas spēkā stāšanās laiku un kārtību [On the Date and Procedure of Entering into Force of the Preamble, Part of Inheritance Law and Property Law of the Restored Civil Law of the Republic of Latvia of 1937] (07.07.1992): Law of RL. Available at http://likumi.lv/doc.php?id=75530 [last viewed October 11, 2015].

32 Сводъ гражАанскихъ узаконеній губерній Остзейскихъ, повеленіемъ государя императора Александра Никоцаевича составленный. Сводъ местныхъ узаконеній губерній Остзейскихъ. Часть третія. Законы гражАанскіе [Collection of Civil Laws of the Baltic Provinces, Compiled upon the Order of Sovereign Emperor Alexander Nikolaevich. Collection of Local Laws of the Baltic Provinces. Part III. Civil Laws]. Санктпетербург: Въ типографіи втораго отдекенія собственной Е.И.В. канцемяріи, 1864. 
tradition. ${ }^{33}$ The circle of lawful heirs was not limited. Derogation from the Soviet procedure of inheritance significantly expanded the circle of heirs. On the one hand, it promoted achieving justice, on the other hand, caused problems. Since in the rural regions the submission of applications regarding restoration of property rights had been completed before the Civil Law entered into force, pursuant to the principle of converging State property, the "vacant" land could already legally be in the hands of other persons. ${ }^{34}$ In such cases, the former owners had to accept allocation of a land plot of equal value or compensation.

Land reform in cities was organised in a more pragmatic way. The decision of 12 June 1991 by RL SC "On Measures for Ensuring Land Reform in the Republic of Latvia Cities" provided that the circle of heirs should be established in accordance with the Civil Law. ${ }^{35}$ Likewise, transferring land for use and restoring the property rights happened, as far as possible, simultaneously. contrast to that in rural regions the land reform was implemented in two stages. During the first stage, the land was granted for use, but property rights to land were restored only in the second stage. ${ }^{36}$ This, however, did not conclude the expansion of the circle of subjects in land denationalisation. Even after Latvia's accession to the European Union, on 14 June 2007 a significant amendment was introduced into laws "On Land Privatisation in Rural Areas" and "On Land Reform in the Republic of Latvia Cities". The persons "who until 21 July 1940 had started purchasing (made a down-payment on) immoveable property left in Latvia by German expatriates from the General Agricultural Bank or the State Land Bank" ${ }^{137}$ were recognised as former owners.

Conversion of state property was based not only upon the principles of justice and equality, but also upon the principle of protection of legitimate expectations. Status $q u o$ and the public interests of the state were not ignored, with sound reasons for

33 Schlosser H. Grundzüge der Neueren Privatrechtsgeschichte. Rechtsentwicklungen im europäischen Kontext. 9., völlig neu bearbeitete und erweiterte Auflage. Heidelberg: C. F. Müller Verlag, 2001, p. 165; Kalniņš V. Latvijas PSR valsts un tiesību vēsture. I. Feodālisma un topošã kapitālisma laikmets. XI-XIX gs. [The History of the State and the Law of Latvian SSR. I The Age of Feudalism and Emerging Capitalism, $11^{\text {th }}-19^{\text {th }}$ c.]. Riga: Zvaigzne, 1972, p. 338; Нольде А. Э. Баронъ. Очерки по исторіи кодификаціи местныхъ гражАанскихъ законовъ при графе Сперанскомъ. Выпукъ II. Кодификація местнаго права Прибалтійскихъ губерній [A Historical Outline of the Codification of Local Civil Laws under Count Speransky. $2^{\text {nd }}$ edition. Codification of the Local Laws of the Baltic Provinces]. С.-Петербургъ: Сенатская типографія, 1914.

34 See: On Land Privatisation in Rural Areas (09.07.1992), Art. 5.

35 Par pasākumiem zemes reformas nodrošināšanai Latvijas Republikas pilsētās [On Measures for Ensuring Land Reform in the Republic of Latvia Cities] (12.06.1991): Decision of RL. Available at $\mathrm{http}: / /$ likumi.lv/body_print.php?id $=67959$ \&grozijumi $=0$ \&pielikumi $=0 \&$ saturs $=0$ \&piezimes $=0 \& 1$ arge_font $=0$ [last viewed May 23, 2016].

36 On Land Reform in the Rural Areas of the Republic of Latvia (21.11.1990), Art. 4; On Land Reform in the Republic of Latvia Cities (20.11.1991), Art. 5.

37 Grozijumi likumā "Par zemes privatizāciju lauku apvidos" [Amendments to the Law "On Land Privatisation in Rural Areas"] (14.06.2007): Law of RL, Art. 5. Available at http://likumi.lv/ta/ id/159483-grozijumi-likuma-par-zemes-privatizaciju-lauku-apvidos- [last viewed October 13, 2015]; Grozījumi likumā "Par zemes reformu Latvijas Republikas pilsētās" [Amendments to the Law "On Land Reform in the Republic of Latvia Cities"] (14.06.2007): Law of RL, Art. 9.3. ${ }^{1}$ Available at http://likumi.lv/ta/id/159540-grozijumi-likuma-par-zemes-reformu-latvijas-republikas-pilsetas-9 [last viewed October 13, 2015]. 
that. $^{38}$ The author is deeply convinced that the need for the implementation of such policy has been most aptly explained by Prof. Andris Plotnieks, the member of RL SC:

"If we are going to declare as inviolable the property as it was 50 years ago and in the name of it shatter the existing property into pieces, then, I am afraid, we shall gain neither authority, nor trust in the eyes of the world." 39

Property rights were not restored and allocation of an equally valuable land plot or compensation had to be accepted, if the following were found on former owners' land:

1) legally purchased or constructed residential buildings, or if the construction thereof had been started, retaining for the owners of these buildings a household land plot;

2) objects of nature specially protected by the state; land envisaged for historical, culture, archaeological, scientific research and studies; as well as, in cities, land on which national sports facilities were located;

3) objects of civil engineering and transport infrastructure of national or local government importance - streets, bridges, tunnels, road overpasses, railway lines and ports;

4) in rural regions the list approved by the Council of Ministers of the Republic of Latvia included also deposits of mineral resources of industrial significance; land claimed by local governments or land on which production facilities owned by natural or legal persons and structures, buildings of public importance or orchards were located..$^{40}$

In addition to that, land reform meant also liquidation of former Soviet economic units - kolkhozs ${ }^{41}$ and sovkhozs $s^{42}$. The political consistency of state reforms and economic stability turned into another restriction upon the rights of former land owners. Thus, for example, in the period of 1989-1990, the so-called "reconstruction" of the USSR, approximately 8000 farms of the so-called "Bresis' farmers" 43 " had been established. ${ }^{44}$ The conflict of the property rights of current and former owners caused clashes of divergent opinion. Thus, for example, the member of RL SC Edvins Kide

38 Lazdiņš J. Experience of nationalisation and denationalisation of Land Ownership in Latvia (19 and $20^{\text {th }}$ centuries). Law and Justice (Selected articles of 2004-2005), 2007, pp. 20-22.

39 Transcript of the sitting of 29 May 1991 (evening session).

40 On Land Reform in the Rural Areas of the Republic of Latvia (21.11.1990), Art. 12; On Land Reform in the Republic of Latvia Cities (20.11.1991), Art. 12.

${ }^{41}$ A kolkhoz was a form of collective farm (suggesting collective ownership) in the Soviet Union or a collective farm of the former Union of Soviet Socialist Republics. The land remained state property. The land was transferred to collective farms only in use, but not in ownership.

42 A sovkhoz was a state-owned farm.

43 Vilnis Edvins Bresis was the Chairman of the Council of Ministers of the Latvian Soviet Socialist Republic in 1988-1990. The owners of first privately-owned farms in the Soviet Latvia were called so, after the surname of the Chairman of the Council of Ministers.

44 Lazdinšs J. Zemes ippašuma nacionalizācijas un denacionalizācijas pieredze (19.-21. gadsimts) [Trends in the Development of Law of the Republic of Latvia Following the Restoration of Independence in 1990-1991]. Likums un Tiesības, 2005, Vol. 7, No. 6 (70), p. 175. 
saw "Bresis' farmers" as "the harbingers of the courage to undermine the socialist agriculture and the socialist principles" ${ }^{45}$ whereas the member of RL SC Anna Seile could not accept that "the borders [rights] of the pre-reform farmer or the Bresis' farmer are as sacred as the Indian white cow". 46 The author holds it fortunate that the majority of RL SC members supported legally consistent continuation of reforms. Thus, if a farm or a household plot had been established on former owners' land and buildings owned by the former land owners were not located on it, the property right could not be restored.

The land reform "created" also a peculiar construction of divided immoveable property. This situation occurred, when one person had legal property rights to a building or other engineering structure, but the property right to land had been restored to the former owners. The understanding of a divided property is contrary to the principle of the unity of immoveable property (building or other construction and land), known in modern civil law. The right of divided property was legalised by the law "On the Date and Procedure of Entering into Force of the Preamble, Part of Inheritance Law and Property Law of the Restored Civil Law of the Republic of Latvia of $1937 " .{ }^{47}$ The member of the working group for restoring the Civil Law, Prof. Jānis Rozenfelds recalls that "[this] proposal, which has had a fatal impact upon the Latvian legal regulation on immoveable property, took the members of the working group by surprise." 48 The aim of the law - to legalise the actually existing property relationships - was reached. The same cannot be said about further relationships between the owners. Not in vain, laws on land reform had to established the so-called relationship of enforced lease of land. ${ }^{49}$ However, the relationship of enforced lease of land can be recognised as being only a provisional regulation.

The construction of divided property was known also in inter-war Latvia. On 8 December 1938, the law "On Revoking the Right of Divided Property" 50 was adopted. It seems that a law with a similar content should be adopted also in the present-day Latvia, to end the relationships of enforced lease.

45 Transcript of 10 June 1992 (evening session).

46 Transcript of 10 June 1992 (evening session).

47 See. in law: Art. 14.

48 Qtd. from: Lazdinš J. Latvijas Republikas tiesību attīstỉbas tendences pēc neatkarības atjaunošanas 1990.-1991. gadā [Trends in the Development of Law of the Republic of Latvia Following the Restoration of Independence in 1990-1991]. Latvijas Universitātes Žurnāls "Juridiskā zinātne", 2010, No. 1, p. 58.

49 According to the most recent amendments, the enforced lease payment may not exceed 5-6\% annualy of the cadastre value of land, depending upon the location of the immoveable property. See: On Land Privatisation in Rural Areas (09.07.1992), Art. 6.4/6; On Land Reform in the Republic of Latvia Cities] (20.11.1991), Art. 12.2/2. ${ }^{1}$

50 Par dalitu īpašuma tiesību atcelšanu [On Revoking the Divided Property Right] (08.12.1938): Law of RL. Likumu un Ministru kabineta noteikumu krājums, 1938, No. 224. 


\section{Conclusions}

1. In the Latvian Republic, following de facto restoration of the state's independence, land property was denationalised with the aim of restoring historical justice in legal property relationships, which had been ignored during the years of Soviet power. Therefore, denationalisation of properties was defined as a priority vis-à-vis general privatisation.

2. Restitution of property rights is one of the aspects substantiating the state continuity.

3. The restitution of former owners' property rights was based on the principles of justice and equality. Restitution of property rights was linked neither to the citizenship, nor the place of residence of former owners.

4. Comprehensive restitution of the right to property following an occupation of the state that has lasted for 50 years is impossible. Consequently, many former owners had to accept compensation or allocation of property of equal value.

\section{BIBLIOGRAPHY}

\section{Literature}

1. Grasmann G., David R. [u. and.]. Einführung in die großen Rechtssysteme der Gegenwart. 2. deutsche Auflage. München: C. H. Beck'sche Verlagsbuchhandlung, 1988.

2. Grūtups A. Tiesu prakse un komentāri [Case Law and Commentaries]. Rīga: Mans īpašums, 1994.

3. Grūtuts A., Krastiņš E. Īpašuma reforma Latvijā [Property Reform in Latvia]. Rĩga: Mans ipašums, 1995.

4. Kalniņ̌̌ V. Latvijas PSR valsts un tiesību vēsture. I. Feodālisma un topošā kapitālisma laikmets. XI-XIX gs. [The History of the State and the Law of Latvian SSR. I The Age of Feudalism and Emerging Capitalism, $11^{\text {th }}-19^{\text {th }}$ c.]. Rìgā: Zvaigzne, 1972.

5. Kleinheyer G., Schröder J. (Hrsg.). Deutsche und Europäische Juristen aus neuen Jahrhunderten. Eine biographische Einführung in die Geschichte der Rechtswissenschaft. 5., neu bearbeitete und erweiterte Auflage. Heidelberg: C. F. Müller Verlag, 2008.

6. Lazdiňš J. Zemes īpašuma nacionalizācijas un denacionalizācijas pieredze (19.-21. gadsimts) [The Experience of Nationalisation and Denationalisation of Land Property $\left(19^{\text {th }}-20^{\text {th }}\right.$ century) $]$. Likums un Tiesības, 2005 , Vol. 7, No. 6 (70), pp. 168-178.

7. Lazdiňš J. Experience of Nationalisation and Denationalisation of Land Ownership in Latvia ( $19^{\text {th }}$ and $20^{\text {th }}$ centuries). Law and Justice (Selected articles of 2004-2005), 2007, pp. 15-22.

8. Lazdiņš J. Latvijas Republikas tiesību attīstības tendences pēc neatkarības atjaunošanas 1990.-1991. gadā [Trends in the Development of Law of the Republic of Latvia Following the Restoration of Independence in 1990-1991]. Latvijas Universitātes Žurnāls "Juridiskā zinātne", 2010, No. 1, p. 53-80.

9. Lazdiņš J. Īpašums kā vērtîba. Īpašuma denacionalizācija / Property as value. Denationalization of state property. Tiesību efektivitāte postmodernā sabiedrībā. LU 73. konferences rakstu krājums. Latvijas Universitāte, 2015, pp. 354-360. 
10. Lazdiņš J. (eds.), Kučs A., Pleps J., Kusiņ̌̌ G. Latvijas valsts tiesību avoti. Valsts dibināšana neatkarības atjaunošana. Dokumenti un komentāri [Sources of Law of the Latvian State. Establishment of the State - Restoration of Independence. Documents and Commentaries]. Rìga: Tiesu Namu Aǵentūra, 2015.

11. L,eñins V. I. Valsts un revolūcija. [State and Revolution]. [S.1]: Zvaigzne ABC, [no date].

12. Luts-Sootak, M., Osipova, S., Schäfer, Fr.L. (Hrsg./eds.). Einheit und Vielfalt in der Rechtsgeschichte im Ostseeraum. Sechster Rechtshistorikertag im Ostseeraum, 3.-5. Juni 2010 Tartu (Estland) / Riga (Lettland). Frankfurt am Main, Berlin, Bern, Bruxelles, New York, Oxford, Wien: Peter Lang, Internationaler Verlag der Wissenschaften, 2012, Bd. 428.

13. Markss K., Engelss F. Komunistiskās partijas manifests [The Manifesto of the Communist Party]. [S.l.]: Zvaigzne ABC, 2008.

14. Rüthers B., Fischer Ch. Rechtstheorie. Begriff, Geltung und Anwendung des Rechts. 5., überarbeitete Auflage. München: Verlag C. H. Beck, 2010.

15. Schlosser H. Grundzüge der Neueren Privatrechtsgeschichte. Rechtsentwicklungen im europäischen Kontext. 9., völlig neu bearbeitete und erweiterte Auflage. Heidelberg: C. F. Müller Verlag, 2001.

16. Нольде А. Э. Баронъ. Очерки по исторіи кодификаціи местныхъ гражданскихъ законовъ при графе Сперанскомъ. Выпукъ II. Кодификація местнаго права Прибалтійскихъ губерній [A Historical Outline of the Codification of Local Civil Laws under Count Speransky. $2^{\text {nd }}$ Edition. Codification of the Local Laws of the Baltic Provinces]. С.-Петербургъ: Сенатская типографія, 1914.

\section{Legislative acts}

1. Latvijas Padomju Sociālistiskās Republikas Konstitūcija (Pamatlikuma) [Constitution of the Latvian Soviet Socialist Republic (Basic Law)] (25.08.1940): Law of the Latvian SSR. Valdỉbas Vēstnesis, 1940, No. 194.

2. Dekalarācija par Latvijas Republikas neatkarïbas atjaunošanu [Declaration of the restoration of independence of the Republik of Latvia] (04.05.1990): Law of the Republic of Latvia (hereafter - RL). Available at: http://likumi.lv/doc.php?id=75539 [last viewed May 17, 2016].

3. Par dalītā ĩpašuma tiesỉbas atcelšanu [On Revoking the Divided Property Right (08.12.1938): Law of RL. Likumu un Ministru kabineta noteikumu krājums, 1938, No. 224.

4. Latvijas Padomju Sociālistiskās Republikas Civilkodekss [The Civil Code of the Latvian Soviet Socialist Republic] (27.12.1963): Law of the Latvian SSR. Latvijas Padomju Sociālistiskās Republikas Augstākās Padomes un Valdības Ziņotājs, 1964, No. 1.

5. Par agrāro reformu Latvijas Republikā [On Land Reform in the Republic of Latvia] (13.06.1990): Decision of RL. Available at http://likumi.lv/doc.php?id=76206 [last viewed September 29, 2015].

6. Par zemes reformu Latvijas Republikas lauku apvidos [On Land Reform in the Rural Areas of the Republic of Latvia] (21.11.1990): Law of RL. Available at http://likumi.lv/doc. php?id=72849 [last viewed May 20, 2016].

7. Par namīpašumu atdošanu likumīgajiem ippašniekiem [On Return of Building Properties to Rightful Owners] (30.10.1991): Law of RL. Available at http://likumi.lv/doc.php?id=70828 [last viewed May 15, 2016].

8. Par zemes reformu Latvijas Republikas pilsētās [On Land Reform in the Republic of Latvia Cities] (20.11.1991): Law of RL. Available at http://likumi.lv/doc.php?id=70467 [last viewed May 20, 2016]. 
9. Par valsts īpašuma un tā konversijas pamatprincipiem [On State Property and Basic Principles of Its Conversion] (20.03.1991): Decision of RL. Available at http://likumi.lv/doc. php?id=65829 [last viewed September 29, 2015].

10. Par pasākumiem zemes reformas nodrošināšanai Latvijas Republikas pilsētās [On Measures for Ensuring Land Reform in the Republic of Latvia Cities] (12.06.1991): Decision of RL. Available at http://likumi.lv/body_print.php?id=67959\&grozijumi=0\&pielikumi=0\&saturs $=0 \&$ piezimes $=0 \&$ large font $=0$ [last viewed May 23, 2016] .

11. Par zemes lietošanu un zemes ierīcibu [On Land Use and Land Survey] (21.06.1991): Law of RL. Available at http://nais.lv/vtext.cfm?Key=012701199106213277320050\&idv=45485 [last viewed June 2, 2016].

12. Par atjaunotā Latvijas Republikas 1937. gada Civillikuma ievada, mantojuma tiesību un lietu tiesību daļas spēkā stāšanās laiku un kārtību [On the Date and Procedure of Entering into Force of the Preamble, Part of Inheritance Law and Property Law of the Restored Civil Law of the Republic of Latvia of 1937 ](07.07.1992): Law of RL. Available at http://likumi.lv/doc. php?id=75530 [last viewed October 11, 2015].

13. Par zemes privatizāciju lauku apvidos [On Land Privatisation in Rural Areas] (09.07.1992): Law of RL. Available at http://likumi.lv/doc.php?id=74241 [last viewed May 15, 2016].

14. Grozijumi likumā "Par zemes reformu Latvijas Republikas pilsētās" [Amendments to the Law "On Land Reform in the Republic of Latvia Cities"] (31.03.1994): Law of RL. Available at http://likumi.lv/ta/id/58064-grozijumi-likuma-par-zemes-reformu-latvijas-republikaspilsetas- [last viewed May 26, 2016].

15. Grozījumi likumā "Par zemes privatizāciju lauku apvidos" [Amendments to the Law "On Land Privatisation in Rural Areas"] (14.06.2007): Law of RL. Available at http://likumi.lv/ta/ id/159483-grozijumi-likuma-par-zemes-privatizaciju-lauku-apvidos- [last viewed October 13, 2015].

16. Grozījumi likumā "Par zemes reformu Latvijas Republikas pilsētās" [Amendments to the Law "On Land Reform in the Republic of Latvia Cities"] (14.06.2007): Law of RL. Available at http://likumi.lv/ta/id/159540-grozijumi-likuma-par-zemes-reformu-latvijas-republikaspilsetas- 9 [last viewed October 13, 2015].

17. Deklarācija par zemes pasludināšanu tautas ippašumā [Declaration on Proclaiming Land to be Property of the People](22.07.1940): Declaration of the Latvian SSR. Valdības Vēstnesis, 1940, No. 167.

18. Par KPFSR likumu (kodeksu) piemērošanu Latvijas PSR teritorijā [On Application of the Laws (Codes) of the Russian SFSR on the Territory of the Latvian SSR] (25.11.1940.): Announcement by the Council of People's Commissars of the Latvian SSR. Latvijas PSR Augstākās Padomes Prezidija Ziņotājs, 1940, No. 74.

19. Par Latvijas generālapgabalā spēkā esošām tiesībām un par rīcỉbu ar spriedumiem un lemmumiem [On the Law Valid in Province General of Latvia and Handling of Judgements and Decisions] (13.06.1942): Rules of the German Occupation Power. Rikojumu Vēstnesis, 1942, No. 124.

20. Сводъ гражданскихъ узаконеній губерній Остзейскихъ, повеленіемъ государя императора Александра Николаевича составленный. Сводъ местныхъ узаконеній губерній Остзейскихъ. Часть третія. Законы гражданскіе [Collection of Civil Laws of the Baltic Provinces, Compiled upon the Order of Sovereign Emperor Alexander Nikolaevich. Collection of Local Laws of the Baltic Provinces. Part III. Civil Laws]. Санктпетербург: Въ типографіи втораго отдеменія собственной Е.И.В. канцемяріи, 1864. 


\section{Other sources}

1. 1991. gada 29. maija sēdes stenogramma (rīta sēde) [Transcript of the sitting of 29 May 1991 (morning session)]. Available at http://saeima.lv/steno/AP_steno/1991/st_910529.htm [last viewed June 2, 2016].

2. 1991. gada 29. maija sēdes stenogramma (vakara sēde) [Transcript of the sitting of 29 May 1991 (evening session)]. Available at http://saeima.lv/steno/AP_steno/1991/st_910529v. htm [last viewed June 1,2016].

3. 1992. gada 10. jūnija stenogramma (vakara sēde) [Transcript of 10 June 1992 (evening session)]. Available at http://saeima.lv/steno/AP_steno/1992/st_920610v.htm [last viewed June 1, 2016]. 
Eduards Bruno Deksnis, $\mathrm{PhD}$

Baltic Strategic Studies Centre, Latvian Academy of Sciences, Latvia

\title{
THE LEGACY OF PUBLIC DIPLOMACY BY THE LATVIAN EXILE COMMUNITY DURING RESTORATION OF LATVIAN INDEPENDENCE
}

\begin{abstract}
Summary
Latvian refugees viewed themselves as exiles in that they en masse expressed their desire to return home to an independent Latvia. They soon discovered the very limited practical relevance to realising this goal in the light of the US-led policy of non-recognition of the annexation and incorporation of Latvia by the USSR. Most of their protests and demands were based on emotions, which, although they derived from real experience, did not have a sufficient power to effect a rollback of Soviet power from Latvia. During the 1970s public diplomacy by Latvian started to include legal arguments. During the run-up to the recovery of Latvian independence in the late 1980s, Latvian exiles engaged as facilitators in the public diplomatic outreach of their compatriots. A number of former lobbyists and political activists entered, some quite successfully, the renewed Foreign Service of the Republic of Latvia.
\end{abstract}

Keywords: non-recognition policy, Latvian exiles, international outreach, the Foreign Service of Latvia, public diplomacy.

\section{Introduction}

Latvian refugees coming into contact with the Western Allies during the final months of the Second World War were astonished and dismayed at the wide-spread public acceptance of their being Soviet citizens. The immediate consequences were; firstly, the likelihood of immediate involuntary repatriation to the USSR, and, secondly, the realisation that the independence of their country was almost irretrievably lost. Public diplomacy either as individuals or in groups was born out of a necessity to communicate their views and demands. This paper does not examine efforts by the very few accredited diplomats of the Republic of Latvia still in post in meeting the aforementioned challenges. Their efforts were significant and important. Initially, they were barred access to their countrymen in refugee camps in the West. Later they took a position supportive of, but not integrated into, popular diplomacy by the Latvian exile community / Diaspora. ${ }^{1}$

There are several distinct phases in the evolution of public diplomacy skills and manifestations of the Latvian refugee-exile community. Initially, these activities centred on relatively compact communities, i.e. those living in Displaced Persons camps in Germany and Austria, having a commonality of purpose, as well as

Latvians saw themselves during the post-war period as exiles, whereas many outside observers accorded them the status of stateless refugees; the term Diaspora has only become current with Latvians living outside of Latvia after restoration of independence in the early 1990s. 
considerable free time to devote to these efforts. Later, once Latvian Displaced Persons had dispersed to several Western countries and also scattered further within each country of residence, public diplomacy efforts were fragmented, based on enthusiasm and a popular belief that independence might be shortly restored. These campaigns were tempered by individual needs to establish an economic basis for survival under new and often daunting conditions. Imperceptibly, Latvian exile efforts took on several rote features, which were only challenged when in the late 1960s a kind of rapprochement was imminent between the USSR and the West, setting immutably the borders of European states. Latvian communities in the Western World, principally in the USA, added a new international dimension to their public diplomatic efforts.

It was, however, with the advent of a revived US effort to move beyond simple containment of Soviet foreign adventurism, usually associated with the two terms in office of US President Ronald Reagan, that public diplomacy by Latvian activists entered a new, more mature phase. Public diplomacy campaigns launched during the single term presidency of G. H. W. Bush were coupled with outreach to the international by representatives of significant political movements in Latvia. Finally, once Latvian state independence was restored, a number of Latvian exiles (i.e. born in Latvia) and members of the Latvian Diaspora (born abroad of Latvian parents) were able to join the reborn Ministry for Foreign Affairs of the Republic of Latvia, including its Diplomatic Service.

\section{Public diplomacy addressing US President of R. Reagan and G. H. W. Bush}

The Latvian community in the USA over five US presidencies had developed its internal political campaign techniques both in the public domain, i.e. demonstrations, agitation, letter-writing campaigns, and in their contacts with the foreign policy makers of the US government. This sustained effort has been well studied over the period up to the early 1970s. The ethnic Latvian community, which resided in the USA prior to the demise of Latvian independence during the Second World War was not very active politically with the exception of agitation for US recognition of Latvia as an independent state in the early 1920s, with part of the community joining in political demonstrations organised by and largely consisting of Lithuanians living in the USA by reason of this community being much larger by an order of magnitude than the Latvian American community. Thus, arrival of a distinctly disgruntled contingent of at least 30000 Latvian exiles during the early 1950s was followed by that their having establish political lobbying groups at national and local level. Unlike the newly arrived Lithuanian exiles, the Latvians had no one to explain to them the complex mix of the silly, the superficial and the serious aspects of public political discourse in the USA. ${ }^{2}$ Their extremely conservative political beliefs, coupled with

2 Lithuanians born in the USA guided their newly arrived compatriots in achieving an enduring US government denunciation of the illegitimate, and to the USA, unacceptable nature of Soviet actions 
posturing by individual self-appointed representatives are some of the reasons why the Latvian American community's demand for justice was for a long time dismissed by a large swathe of the US public, and an even larger segment of the US academic community specialising in analysis of the Soviet Union as hopeless irredentist romantics whose opinions were rejected by their fellow-countrymen in the homeland. ${ }^{3}$ It is also the case that the efforts by Latvian émigrés were derided by their Soviet masters, who on occasion persecuted those who had the temerity to recall the independence period in other than official negative terms. ${ }^{4}$

Baltic émigrés were horrified by any evidence of the US government quietly abandoning its resolute legal stand on non-recognition of the forcible annexation and incorporation of the Baltic States by the USSR. The last of several internal State Department attempts at such a revisions occurred under the Presidency of Gerald Ford, more to the point under the non-attributable direction of Henry Kissinger. Leakage from State Department officials provoked the US Baltic communities to act, and in this they were helped by the unusual coincidence of Gerald Ford having a personal appreciation of the Baltic exile cause well in advance of this incident. ${ }^{5}$ On the other hand, President Ford later has been forthright in that he decided to sign the Final Act in Helsinki in the face of displeasure from Eastern European lobbyists in the USA since,

“... people who were critical in the United States didn't understand what the impact would be with the human rights provision. They were so frozen in their opposition to the Soviet Union, and the way the Soviets, for example, had treated Latvia, Estonia and Lithuania. They didn't realize that the human rights provision would end up with the kind of freedom that they wanted in the Baltic Nations. And it took time, it took the human rights development to convince them that Helsinki was a great step forward and a time bomb for communism."'

in annexing the Baltic State; the way Rep. C. Kersten was advised to begin his enquires and later publish Conclusions is well laid out in L'Hommedieu, J. L. Exiles and Constituents: Baltic Refugees and American Cold War Politics, 1948-1960. Ph. D. thesis Turku University, 2011, pp. 268-271; no US Latvians figure in the list of individuals involved in initiating this activity.

3 As late as 1990, J. F. Hough published the opinion that non-Russian nationalities were unlikely to separate from the central authority of the USSR, despite it being essentially Russian as their elites had more to gain by remaining part of the empire, focussing on the Lithuanians, in particular, whose moves towards independence were not supported by politically correct Sovietologists, see Hough, J. F. Russia and the West: Gorbachev and the Politics of Reform, New York: Touchstone, 1990, p. 206.

4 For one study of a such repressive policies see Zake I. Soviet Campaigns against "Capitalist Ideological Subversives” during the Cold War The Latvian Experience. Journal of Cold War Studies, Vol. 12, No. 3, Summer 2010, pp. 91-114

5 See Zake I. Goals and tactics of President Gerald Ford's ethnic politics, Nationalities Papers: The Journal of Nationalism and Ethnicity, Volume 43, Issue 6, 2015, pp. 944-961; political correctitude today sees this activity as an example of ethnic anti-communism, Zake I., Gormley G. Integration or Separation?: Nationality Groups in the US and the Republican Party's Ethnic Politics, 1960s-80s. Nationalities Papers: The Journal of Nationalism and Ethnicity, 2010, Volume 38, Issue 4, pp. 469-490.

6 Online interview. Available at http://www.gwu.edu/ nsarchiv/coldwar/interviews/episode-16/ ford 1.html [last viewed November 12, 2015]. 
There was little progress towards their goal of seeing an independent Republic of Latvia de facto take on its de iure form during the so-called Helsinki follow-up process. Baltic demonstrators sought to attract attention to the Baltic issue gaining some ground in terms of publicity but no movement was evident towards the international community inducing the USSR even to admit the problem, let alone subject its resolution to international diplomacy. It is useful to recall that the Helsinki followup meetings were intended to be progress reports on implementation of various provisions of the Helsinki Final Act, and since the Act had no binding legal standing, not being an international treaty, so the follow-on meetings became presentations by various parties to the Acts of their self-assessment. They were punctuated by arguments reflecting the downturn in relations between the USSR and Western countries, particularly after the Soviet invasion of Afghanistan. Baltic issues were visible along the margins of the meeting; ${ }^{7}$ communications from Baltic dissidents in-country to various international organisations and governments, were more visible in that these missives were distributed by Western Baltic organisations. ${ }^{8}$ Notwithstanding the sincerity and truthfulness of these requests for assistance, their authors were viewed as individuals and the political context of their plight daunting, such that these communications had little immediate impact.

\section{Public diplomacy addressing US Presidents R. Reagan and G. H. W. Bush}

Undoubtedly, the arrival of R. Reagan as US President was heartily welcomed by Baltic groups in the USA and elsewhere, given his track record of outspoken anticommunism. Once at the helm, President Reagan was supportive on a rhetorical level, including mention at the UN, ${ }^{9}$ and approving annual Baltic Freedom Days from 1983 onwards. During his first term in office broadcasts in Latvian were transferred from Radio Liberty (target audience the peoples of the USSR) to Radio Free Europe (the peoples of Eastern Europe, i.e. outside of the USSR). Whether the audience appreciated this subtle change in 'status' is unclear. It was also the case that individual Baltic dissidents "benefitted" from their case being argued in great detail by Baltic lobbying groups in the USA by being granted exit visas; however, their ultimate goal of seeing a recovery of independence (implicitly) as a result of

Cf. Snyder S. B. Human Rights Activism and the End of the Cold War: A Transnational History of the Helsinki Network, Cambridge University Press: 2011, at p. 98; Baltic émigré activities, including JBANC submissions, are mentioned and positively remarked upon. A more extensive appreciation of Baltic lobbying at the 1985 Ottawa CSCE expert meeting on human rights is found in Hazewinkel, H. J. Ottawa 1985 - the half-way meeting recollections of a participant, published in OSCE ODIHR Bulletin Vol. 3, No. 3, 1995, pp. 41-47.

8 One such instance was the 23 August 1979 memorandum from 45 Balts (four Estonians, four Latvians and 37 Lithuanians) sent to the United Nations calling for publication of the full text, including the secret protocols, of the Molotov-Ribbentrop Pact.

9 United States Mission to the United Nations Statement, delivered by Ambassador Jeanne Kirkpatrick being a copy of a statement issued by US President Reagan. Available at http://vm.ee/sites/default/ files/content-editors/web-static/182/President_Reagan_statement.pdf [last viewed August 8, 2015]. 
Western pressure came no closer. The 1988 visit by President Reagan to Moscow included a reception for Soviet dissidents including one Latvian dissident at the US embassy in Moscow, but President Reagan mentioned Baltic issues in a passing and opaque manner during his speech to a well-chosen student audience at Moscow State University,

"We can only hope that it won't be long before all are allowed to do so [freedom for Soviet citizens to visit foreign countries] and UkrainianAmericans, Baltic-Americans, Armenian-Americans can freely visit their homelands, just as th(e) Irish-American visits his." ${ }^{10}$

Baltic American lobbyists both through their joint organisations and national organisations had lobbied US President Reagan to bring to M. Gorbachev's attention the US non-recognition policy. The very dusty, yet correct, reply to these submissions was that the USSR was quite aware of US policy and that repetition would serve little purpose.

While the archives of President Reagan and his senior assistants indicate that Baltic issues were regarded as public relations issues, the advent of substantial in-country political forces during the late 1980s promoted Baltic issues to the status of being intimately related to international relations matters. It was not the case that most Ministries of Foreign Affairs in Western counties were unaware of the illegitimate nature of Soviet annexation of the Baltic States, personal heart-felt obduracy on the part of Soviet politicians and diplomats meant that discussing the issue would bear no fruit. Once it became evident that objectively substantial majorities (overwhelming if looking at the titular Baltic nationalities) were prepared publically to demonstrate their political will in the face of a not entirely concealed Soviet desire for physical repression Western countries at least internally had to reconsider their posture. However, none went so far as to take diplomatic steps to persuade the USSR leadership to let the Baltic countries depart all private remonstrance to the contrary. ${ }^{11}$

In fact, the letter by President Bush to President Gorbachev (undated, but likely 23 August 1991) pointed out the error that the latter had committed by not letting the Baltics go free earlier:

"You know our long-standing position that the Baltic States were illegally incorporated into the USSR and should be free. I have told you more than once that I believe very strongly that the USSR would be better off with them as neighbors than as unwilling members of the union.

10 See http://millercenter.org/president/reagan/speeches/speech-3416 [last viewed August 8, 2015].

11 For a balanced view of Baltic aspirations for independence, see French National Archives AG 4/CD 242, Dossier 4, note by Jacques Blot of 3 April 1990 quoted in Bergmane, U. Diplomacy and Diasporas, self-perceptions and representations: Baltic attempts to promote independence, 1989-1991, at p. 198, Chapter 9 in Clerc L., Glover, N. Paul Jordan, P. (eds.). Histories of Public Diplomacy and Nation Branding in the Nordic and Baltic Countries: Representing the Periphery. Diplomatic Studies Series. Leiden: Brill Nijhoff, 2015. 
I believe this to be the best course of action for you and the Baltic States. I urge you to adopt this without hesitation. If you are unable to do this by August 30, I will nevertheless be forced to announce the intention of the Unites States to begin negotiations with the three Baltic States to establish diplomatic relations." 12

President Bush strongly hinted at the progress being made towards recognition of the restored Baltic States in a press conference of 27 August 1991. He also seems to suggest resistance put up by M. S. Gorbachev, the details of which appear not to have been archived.

One measure of the type of diplomatic activity being engaged in by US Baltic supporters of independence is seen in a letter of 23 May 1990 to President Bush, that

- the Soviet Union should acknowledge Baltic exceptionalism;

- the Soviet Union should immediately cease all economic and political pressure on the Baltic States;

- President Gorbachev should immediately announce the beginning of formal talks with the governments [sic] of the Baltic Republics. ${ }^{13}$

It is curious that the American Latvian Association had decided in 1990 that the Supreme Council of Latvia and the Council of Ministers, which it formed following none of the provisions of the 1922 Constitution of the Republic of Latvia, was a legitimate government of the Republic of Latvia.

\section{After independence rebuilding sovereign administrative bodies in Latvia}

Undoubtedly, there were high expectations by the majority in Latvia who had only a partial view of the extent in numbers and financial resources of their fellow Latvians living abroad that independence would be accompanied by mass repatriation. Excepting the cultural field, whereby fifty years of accumulated literary and other cultural valuables returned, there were remarkably few returnees as such. Figures are hard to find, but the numbers of those who registered their intent to acquire Latvian citizenship prior to 1 July 1995 were limited. Latvian records show that 20636 individuals did so. By way of comparison, US census data for 1990 reported 75747 persons claiming Latvian ancestry, 26179 of whom were born abroad, i.e. mostly in Latvia. ${ }^{14}$

Individual foreign-born Latvians and even those who had left Latvia as babies, or youngsters, took part in re-establishing various state administrative bodies and

12 Memo (no date) with attachment, Message to President Gorbachev on the Baltics, B. Scowcroft to G. Bush, copy at the Burns Nicholas and Hewitt, USSR Chrono File: August 1991 (1), George Bush Presidential Archive.

13 Letter by V. Pavlovskis of 23 May 1990 to President Bush, copy in the National Security Council Collection, Condoleezza Rice files, CF00720-004, G. Bush Presidential Archive

14 Summary data in a report by the US Census bureau. Available at https://www. census.gov/ population/www/documentation/twps0029/tab03.html [last viewed October 18, 2014]. 
ministries, most importantly, the Ministry of Foreign Affairs. An important symbolic step was the return to Latvia on 17 November 1991, for the first time in over 50 years, of Anatols Dinbergs, the most senior member of the Corps of Diplomats of the Republic of Latvia, and Chargé d'Affaires (ad interim) at the Washington Legation. Several younger members of the Latvian exile community who were linked to this Corps of Diplomats subsequently integrated into the re-established foreign service of the Republic of Latvia.

Diplomatic representation during the 1990s of the restored independent Republic of Latvia urgently needed experienced personnel. The diplomatic service passed through a phase that has been termed as the period of "Political Ambassadors". ${ }^{15}$ This term is disingenuous, as even countries with a well-established long history of diplomatic service, occasionally find themselves with an Ambassador whose background is political. In the case of Latvia, a number of political activists were asked to help out in particularly delicate instances, i.e. representation at the UN, in Washington, in the UK, in France, in Sweden, in Germany, in areas where knowledge of foreign languages was essential. Some of these postings turned into long-term engagement as Ambassadors of Latvia. Diplomatic representations were viewed as occasions for political factions at home to install a safe pair of hands to guide private business relations.

Some honorary consulates are manned by Diaspora Latvians. It must be admitted that the Latvian MFA has always been somewhat under-financed. The occasional downsizing of permanent staff has not served the interests of the quality of representation abroad. Undoubtedly, the possibility of Latvian diplomats being seconded to the EU External Action Service has allowed indirect Latvian diplomatic representation in countries, where no national representations are present.

An instructive view of how the diplomatic service was re-instated concerns the decision not to establish a Diplomatic Academy in Latvia. Diplomatic training in Lithuania, as in Latvia, greatly benefitted from the assistance by members of Western diplomatic corps, who helped train new diplomats throughout the 1990s. Exceptionally - this did not happen for the other two Baltic MFAs - ethnic Lithuanians with Western professional diplomatic expertise came to work for the Lithuanian MFA. In Estonia, a private initiative in 1990 resulted in creation of the Estonian School of Diplomacy, which continues to function today. ${ }^{16}$ In Latvia, former senior members of the Latvian Ministry for Foreign affairs are importuned to present their opinions by the media. There is some effort by academics in Latvia to analyse Latvian foreign policy developments, but their judgements all too often are based on theories about how international relations are conducted, as opposed to insight into how these are performed in reality.

15 See the article by a member of the Latvian Foreign service in post at the time of writing this article, i.e. Bishofa M. Has the era of Latvian Political Ambassadors Come to an End? In Scientific Journal of Riga Technical University, The Humanities and Social Science, 2010, Vol. 17, pp. 83-90.

16 Estonian diplomats can express their considered unofficial views on various international matters, in the on-line journal, Diplomaatia. Available at http://www.diplomaatia.ee/en/ [last viewed August 3, 2015]. 


\section{Conclusions}

During their outreach to the international community in 1990/1991, official representatives of all three Baltic independence movements/governments discovered the practical limits to the US-led non-recognition policy. Once independence was solidified, Western diplomatic assistance has been crucial in building up the core of the Latvian Foreign Service. A number of Latvians from the so-called old Diaspora continue to be part of the Latvian Foreign Service. Astute reading of what the Latvian exile/émigré community was able to deliver in tangible, as opposed to rhetorical terms of lobbying Western authorities to the benefit of their compatriots in the homeland meant that already in 1991 appeals were made to the external communities that in remaining abroad they could continue to lobby the interests of Latvia more effectively, were these efforts to align with Latvian foreign policy initiatives.

\section{BIBLIOGRAPHY}

\section{Literature}

1. Bergmane, U. Diplomacy and Diasporas, self-perceptions and representations: Baltic attempts to promote independence, 1989-1991, at p. 198, Chapter 9 in Clerc L., Glover N., Paul Jordan P. (eds.). Histories of Public Diplomacy and Nation Branding in the Nordic and Baltic Countries: Representing the Periphery. Diplomatic Studies Series. Leiden: Brill Nijhoff, 2015.

2. Bishofa, M. Has the era of Latvian Political Ambassadors Come to an End?, in Scientific Journal of Riga Technical University, The Humanities and Social Science, 2010, Vol. 17, pp. 83-90.

3. Snyder, S. B. Human Rights Activism and the End of the Cold War: A Transnational History of the Helsinki Network. Cambridge University Press, 2011.

4. Hazewinkel, H. J. Ottawa 1985 - the half-way meeting recollections of a participant, published in OSCE ODIHR Bulletin, Vol. 3, No. 3, 1995, pp. 41-47.

5. L'Hommedieu, J. L. Exiles and Constituents: Baltic Refugees and American Cold War Politics, 1948-1960. Ph. D. thesis Turku University, 2011.

6. Hough, J. F. Russia and the West: Gorbachev and the Politics of Reform. New York: Touchstone, 1990, p. 206.

7. Zake, I. Soviet Campaigns against "Capitalist Ideological Subversives" during the Cold War. The Latvian Experience. Journal of Cold War Studies, Vol. 12, No. 3, Summer 2010, pp. 91-114.

8. Zake, I. (2015): Goals and tactics of President Gerald Ford's ethnic politics. Nationalities Papers: The Journal of Nationalism and Ethnicity, Vol. 43, Issue 6, pp. 944-961.

9. Zake, I. Gormley, G. Integration or Separation?: Nationality Groups in the US and the Republican Party's Ethnic Politics, 1960s-80s. Nationalities Papers: The Journal of Nationalism and Ethnicity, 2010, Vol. 38, Issue 4, pp. 469-490.

10. US Census bureau. Available at https://www.census.gov/population/www/documentation/ twps.0029/ tab03.html [last viewed October 18, 2014].

11. President G. Ford, online interview. Available at http://www.gwu.edu/ nsarchiv/coldwar/ interviews/ episode-16/ford1.html [last viewed November 12, 2015].

12. Statement issued by US President Reagan. Available at http://vm.ee/sites/default/files/contenteditors/web-static/182/President_Reagan_statement.pdf [last viewed August 8, 2015].

13. US President Reagan's speech. Available at http://millercenter.org/president/reagan/ speeches/speech-3416 [last viewed August 8, 2015]. 


\section{SECTION 2}

SECTION IN HONOUR

OF THE TWENTIETH

ANNIVERSARY OF THE

CONSTITUTIONAL COURT

OF LATVIA 
Lali Papiashvili, Dr. iur.

Tbilisi State University, Constitutional Court of Georgia, Georgia

\title{
MODERN PERSPECTIVES OF STATUTORY INTERPRETATION: IN SEARCH OF A NEW PARADIGM FOR THE CONSTITUTIONAL ADJUDICATION IN GEORGIA
}

\begin{abstract}
Summary
There are traditionally accepted canons of construction in legal theory. Yet practice shows that reality may render existent interpretative methods impotent to address real problems in a workable and practical fashion. To that end, constitutional courts and the judiciary at large around the globe have moved to develop various ancillary strategies to supplant and/or combine additional problem-solving instruments. This article touches upon the techniques mastered by the Constitutional Court of Georgia in order to deal with challenges of legal interpretation in a succinct manner, which has proved to be effective in two major ways; namely, constitutional court decisions are properly executed in practice, as well as individuals affected by the constitutional justice are better served to seek a remedy.
\end{abstract}

Keywords: interpretation of law, constitutional adjudication in Georgia, effectiveness of constitutional justice.

\section{Introduction}

Hans Kelsen's original thinking of concentrated model of constitutional review, designed to ensure and maintain institutional balance between state bodies, has seen gradual evolution over time. Specialised constitutional tribunals are more than a mere arbiter between state institutions. As of today, constitutional courts ${ }^{1}$ often possess a power to invalidate legislative acts on the basis of individual complaints, thereby discharging traditional abstract constitutional review via an individual petition. Proceedings before the constitutional court increasingly become similar to the regular adjudication, as concrete factual circumstances precede the instigation of a case. Therefore, it attaches a particular importance to the institutional cooperation between the common court system and the constitutional court, as both tribunals are now in the habit of deliberating actual cases.

Such a development raises challenges for the constitutional decision-making in two ways; firstly, as to how should the constitutional court, in accordance with the institutional design of concentrated constitutional review, administer its proceedings separately from the ordinary judiciary and, at the same time, effectuate its work vis-à-vis practice in a way that is compatible with the constitution. This

Referring to constitutional courts, tribunals, chambers, supreme courts or other relevant bodies of constitutional review. 
article intends to discuss few cases from the jurisprudence of the Constitutional Court of Georgia, where the Court has introduced a new attitude towards legal interpretation in the course of constitutional decision-making. Initially, theoretical foundations of constitutional review will be outlined, subsequently, different interpretative methods will be expounded that are at the disposal of the legal interpreter. Then, specific cases of the Georgian Constitutional Court will be reviewed in an attempt to elucidate certain novel strategies of statutory interpretation mastered by the Constitutional Court of Georgia to address emerging challenges of effectiveness and practicality of constitutional adjudication.

\section{Systemic peculiarities of constitutional review}

Many countries in the world and certainly all across the Europe have embraced constitutional review as a means of ensuring the supremacy of constitutional values and protecting fundamental human rights. Thus, constitutional control bodies are rightly regarded as an integral part of a modern democratic setting by their unique, yet indispensable character. Despite not being a popularly elected institution, constitutional courts have a mandate to invalidate parliamentary legislation and, accordingly, to influence the policy choices of the legislature.

The mission of judicial review in general serves the purpose of safeguarding the supremacy of the basic law of a country. In doing so, constitutional court is mainly tasked with performing two different kinds of functions: the resolution of disputes among state bodies and the protection of individual rights. ${ }^{2}$ Both of these tasks involve the constraint of present-day political authorities on the basis of constitutional principles. As a neutral third party, the constitutional court acts to ensure that neither the lawmaker nor the executive steps over the boundary of the other's institutional domain. It is also constitutionally empowered to defend an individual from the powerful state apparatus in the interest of certain substantive goals of liberal democracy. Therefore, constitutional courts play a major countermajoritarian role, ${ }^{3}$ as they effectively balance the perceived risk of subverting democratic government by elected officials acting in personal interest. ${ }^{4}$

Judicial review is predominantly exercised in two major ways: either by incidental control (diffuse model), whereby direct access is guaranteed for individuals and ordinary courts are entitled to assess the constitutionality of any legal norm or individual act provided an 'actual controversy' exists between the parties. ${ }^{5}$ The other

2 Ginsburg T., Elkins Z. Ancillary Powers of Constitutional Courts. Texas Law Review, 2009, June, No. 87 , pp. 2-3.

3 For a brief account of judicial review in a modern world, please see: Barroso L. R. The Roles of Supreme Courts and Constitutional Courts in Contemporary Democracies. Available at http:// www.iconnectblog.com/2016/10/the-roles-of-supreme-courts-and-constitutional-courts-incontemporary-democracies [last viewed October 21, 2016].

4 Wright Sheive S. Central and Eastern European Constitutional Courts and the Antimajoritarian Objection to Judicial Review. Law and Policy in International Business, 1995, No. 26, p. 10.

5 Ibid., pp. 1-3. 
model is known as concentrated review, meaning a separate court, placed outside the ordinary court system, is given the power to review the constitutionality of normative acts. The majority of European states, including Georgia, adopt the latter model. ${ }^{6}$

Difference in two systems is duly translated into distinctive jurisdictional structures of constitutional review, as the diffuse model exercises a concrete review of cases arising from a genuine dispute between parties, whereas the specialised constitutional court is more inclined to consider the constitutionality of a part of legislation in principle. ${ }^{7}$ An abstract review invalidates law with effects erga omnes, if it contravenes the constitution. ${ }^{8}$ In contrast, concrete review, to some extent, either substitutes or complements the ordinary dispute resolution by having the constitutional court to resolve individual cases. Such a model goes against Hans Kelsen's original idea of constitutional review, which implies the constitutional court's influence to be primarily exercised through screening legislation in general and shaping policymaking. According to Kelsenian positivist jurisprudence, a strict hierarchy of laws is necessary and ordinary courts should only be confined to applying the law that is legislated by the parliament. As for the normative power of the constitutional order, he argued that it would be better served, if a specialised court were in charge of maintaining the institutional balance between state institutions. ${ }^{9}$

Moreover, some countries go beyond these traditional models and adopt a 'constitutional complaint procedure', which allows individuals to directly apply to the constitutional. ${ }^{10}$ This mixed mechanism enables constitutional review to be instigated by an individual case, whereby either incorrect interpretation of the law was made or the statute itself proved to be deficient. The constitutional court goes on to review the case and pass on its constitutionality in the abstract. ${ }^{11}$ In this scenario, the constitutional court would strike a law and actively interpret the conditions under which it can be implemented. In such a mixed procedure, some level of cooperation and coordination between the constitutional and ordinary courts is essential for proper execution of constitutional court cases. ${ }^{12}$ Georgian example, which will be discussed below, is a good illustration as to how the constitutional court can find an approach to effectuate its decisions in ordinary cases. It is generally argued that the natural goal for the constitutional court in the said context is to achieve

6 Wright Sheive S. Central and Eastern European Constitutional Courts and the Antimajoritarian Objection to Judicial Review. Law and Policy in International Business, 1995, No. 26, pp. 3-4.

7 Study on Individual Access to Constitutional Justice by the Venice Commission. CDL$\mathrm{AD}$ (2010)039rev. Adopted at the 85 ${ }^{\text {th }}$ Plenary Session on 17-18 December 2010, p. 11.

8 Ferreres Comella V. The European Model of Constitutional Review of Legislation: Toward decentralization? International Journal of Constitutional Law, 2004, 1 July, No. 2(3), pp. 463-465.

9 See: Kelsen H. General Theory of Law and State. 1945.

10 Supra note 7, pp. 14-18.

11 Supra note 8, p. 465.

12 Garlicki L. Constitutional Courts versus Supreme Courts. International Journal of Constitutional Law, 2007, 1 January, No. 5(1), pp. 46-48. 
normative supremacy as the highest court in the country over the traditionally deferential regular court system. ${ }^{13}$

\section{Norm-controlling mandate of constitutional courts}

It is argued that constitutional court's mandate has evolved over years to the point where it genuinely competes with the lawmaker. In particular, constitutional review, as ubiquitous as it is, has become determinant of legislative policymaking to a certain extent, the process of which is referred to as judicialisation of politics. ${ }^{14}$ Evidently, the border between law and politics in recent decades has ceased to be clear, yet the separation between the former and the latter remains essential for the idea of constitutional order. Politics is the sphere of the majority's will, whereas law is the space of reason. ${ }^{15}$ Thus, in exercising judicial review, judges are required to use creativity and discretion when interpreting their constitutional mandate for the purpose of balancing and reconciling competing policy preferences. ${ }^{16}$

In the said process, constitutional courts influence not only parliamentary laws, but also judicial decision-making by their overwhelming power to review the application of laws with the constitution. When passing on the constitutionality of legal acts, the constitutional courts intrinsically affect the regular courts' adjudicative mandate. In fact, recent tendencies in constitutional justice suggest a shift from the review of legislator to the review of the judiciary, ${ }^{17}$ which is manifested in the spread of individual complaint mechanism, giving constitutional courts the power to take actual cases and assess the impugned law in abstracto. Therefore, constitutional adjudication has become increasingly fact-driven on the basis of real disputes between parties, quite resembling the ordinary judicial decision-making. Such a development, under the concentrated review model, prompts constitutional courts to assume a leading role in actual cases between parties. As it has already been emphasised above, this makes institutional cooperation between regular courts and the constitutional court even more essential to ensure consistency and effectiveness of the entire legal system.

Despite the broad normative powers, constitutional courts are still required to display some degree of caution and self-restraint to avoid overstepping their constitutional mandate. The presumption of constitutionality exists in theory,

13 Sadurski W. Rights before Courts: A Study of Constitutional Courts in Postcommunist States of Central and Eastern Europe. $2^{\text {nd }}$ edition. Springer, 2005, pp. 19-20, 33-34.

14 Stone A. The Birth of Judicial Politics in France: The Constitutional Council in Comparative Perspective. $1^{\text {st }}$ edition. New York: Oxford University Press, 1992, p. 9.

15 Supra note 3.

16 Supra note 4, p. 3.

17 Paczolay P. Introduction to the Report of the Venice Commission on Individual Access to Constitutional Justice. In: Conference on "Individual Access to Constitutional Justice". Arequipa, Peru, 2013, p. 4. 
implying respect for legislature's work in the democratic process. ${ }^{18}$ In particular, it is argued that policy decisions should be made by the legislators, who are accountable to the people through elections, and 'aggressive' judicial review might undermine this accountability by allowing the judiciary to supersede the will of the electorate. ${ }^{19}$

\section{Interpretation of law and constitutional adjudication}

It has been notoriously argued that the purpose of law, in general, consists in the realisation of the common good, which is an abstract concept defined to combine three elements or functions of the legal order: legal certainty, legitimacy and practicality. ${ }^{20}$ These values are seen as central to legal positivism, which has been actively applied by the Federal Constitutional Court of Germany, underscoring the significance of practical reason or practical rationality in its case law. ${ }^{21}$ In order to grasp the interpretation of law, as well as various interrelated features that accompany this process, the next few paragraphs will attempt to clarify the said concepts of the legal order and outline the factors judges need to account for when applying law in practice.

Under the theory of positivism, two elements gain vital importance - the certainty of meaning and the certainty of obedience to law. Stable norms and clear jurisdiction ought to be supplemented by clear and predictable rules, which provide institutional framework for the entire legal order. ${ }^{22}$ As for the legitimacy, individuals must be able to make sense of legal acts in terms of material justice and the good community at large, implying regulations to be both good and just. ${ }^{23}$ Legitimacy seeks to unite legal and ethical coherence in the framework of law to accomplish the ideal balance between society's needs and fair measures of their implementation.

Practicality's role is more to supplement the other two values. A good understanding of reality is needed to better address challenges. It is quite worth to consider the facts of reality when applying law in practice, because different aspects of reality are prerequisite for a rational, functional, practical solution of the problem that, in turn, leads to the formulation and ensuing interpretation of a particular legal provision. ${ }^{24}$

18 Hessick F. A. Rethinking the Presumption of Constitutionality. Notre Dame Law Review, 2010, June, No. 85, p. 2.

19 Hart J. E. Democracy and Distrust: A Theory of Judicial Review. $1^{\text {st }}$ edition. Harvard University Press, 1980, pp. 101-104.

20 Ibid.

21 The concept of practical reason is applied by the Federal Constitutional Court of Germany. Cited in Supra note 20. "The judicial decision [in case of a gap] fills this gap according to the standards of practical reasoning and the 'community's well established general concepts of justice." (author's translation) (quoting 9 BVerfGE 338, 349 (F.R.G. 1959)). Practical reasoning or practical rationality are also prominently used in Robert Alexy's discourse theory of law. See Alexy R. A Theory of Legal Argumentation: The Theory of Rational Discourse as Theory of Legal Justification. Oxford University Press, 2009.

22 Supra note 20, pp. 3-4.

23 Ibid, pp. 4-5.

24 Supra note 20, p. 5; see also 34 BVerfGE 269, 288 (F.R.G. 1973) [translation from German]. 
Under the school of legal realism, practicality mainly combines the following criteria: a) legal decisions should be based upon an appropriate assessment of reality, sphere of life and the affected interests; b) costs and benefits of legal regulations are to be assessed within specific domain, and within society at large from economic, legal and ethical perspectives; c) effectiveness has to be kept in mind, when legal intervention is intended into the social areas of life. ${ }^{25}$ In particular, effectiveness suggests a rational application of means to established goals, which should combine the best means available to achieve the proper goals in a flexible way. It is believed that the competent state body is to choose the most functional and most acceptable solutions to problems both from legal and ethical standpoints. ${ }^{26}$

Although some level of differentiation is deemed to be made between certainty, legitimacy and practicality, due to their distinctive nature, in practice the combination and integration of the said elements to the possible extent is needed to achieve an ideal setting within the legal order. Such an equilibrium is especially important, when it comes to the interpretation of law. Law-applying bodies, no doubt, have to interpret the expressions and wishes of the legislator in light of the three interrelated legal purposes, as concretised by the constitutional law. ${ }^{27}$ In the process of applying law, the appropriate bodies also have the duty to complement the legislative act to conform therewith. ${ }^{28}$ More specifically, the difference has to be made between the subjective will of the law-maker and the objective will of the law. It is argued that the goals of legal interpretation are to establish the subjective will of the legislature and the objective will of the law. ${ }^{29}$ The latter notion, which is normative will as objectified by the judiciary, involves an obligation to better balance certainty, legitimacy and practicality.

In the interpretive process, some sort of balance between subjectivity and objectivity is required, which is thought to be better ensured by the combination theory as the prevailing method of interpretation. ${ }^{30}$ This approach implies the application of all the relevant methods of interpretation, namely, it is argued that no single method should be excluded from the outset. ${ }^{31}$

There is a common position among most academics and practitioners on the comprehensive character of the traditional canon of construction, which, according to Carl Friedrich von Savigny, comprises grammatical (textual), systematic (contextual),

25 Supra note 20, p. 5; see also 34 BVerfGE 269, 288 (F.R.G. 1973) [translation from German].

26 In theory, this process is regarded as legal pragmatism; in fact, all positivist, idealist and realist theories of law that attempt to achieve some balance between the above-mentioned three elements of the common good can be called pragmatic in this sense. See: Nonet P., Selznick P. Law and Society in Transition: Toward Responsive Law. Transaction Publishers. 2001, pp. 84-86.

27 Supra note 20, p. 7.

28 Ibid.

29 See citation by the Federal Constitutional Court of Germany: "What is crucial for the interpretation of a law is the will of the legislature as it is objectively transformed by the enacted law." [translation from German]. In: 79 BVerfGE 106, 121 (F.R.G. 1988).

30 See: Donato J. Dworkin and Subjectivity in Legal Interpretation. Stanford Law Review, 1988, July, No. 40 .

31 Supra note 20, p. 12. 
historical and teleological (purposive) interpretation. ${ }^{32}$ At the same time, this approach is also considered to be positivist and in need of supplementation. ${ }^{33}$ Yet, interestingly enough, the teleological interpretation forms a part of the other interpretative methods, since what has been said in the law and willed by lawmakers leads to the identification of the purpose of the law in question. Consequently, it is for the interpreter to decide, which aspect of the law to put in the forefront - certainty, legitimacy or practicability. If the court of law does not restrain interpretation to the scope a lawmaker actually willed to regulate, then the question relates to the concepts of legitimacy and practicality. ${ }^{34}$ In the realm of legitimacy, perhaps, all the legal systems embrace certain inherent principles and values that can be invoked by the courts to base their understanding of the just and good.

In a nutshell, combination theory involves several phases in the course of normconstruction: purposes of law (the aforementioned three elements of law), goals of interpretation (the lawmaker's subjective and the law's objective will), and the said four methods of interpretation. ${ }^{35}$ In practice, however, the elements of the common good may support each other or compete with each other. It is, therefore, for the interpreter to deal with the deficiency arising out of the gap between the 'ideal' and the 'real' situation of legislative regulation, namely, uncertainty, inconsistency, impracticality of the legal provision at hand..$^{36}$

It is worth noting that, for the purposes of constitutional adjudication, traditional methods of statutory construction may well require supplementation. ${ }^{37}$ Constitutional interpretative practice is viewed as a special case of statutory interpretation for the beginning of the $20^{\text {th }}$ century. ${ }^{38}$ It is being discussed, whether grammatical, systematic, historical and teleological interpretative canons enable the constitutional court to objectively reach the only right outcome. ${ }^{39}$ In particular, as constitutional court's procedure is seen as 'pragmatic and flexible', it thus would be hard for that court to arrive at the final point in the process of interpretation with absolute perspicuity and consistency. Richard Posner has notoriously promoted utilitarian interpretative strategy, implying social consequences of the judicial decisions should be taken into account in the course of legal interpretation. ${ }^{40}$ Canons of construction in general serve the purpose of providing a better justification for decisions and

32 See: Hesse K. Grundzüge des Verfassungsrechts der Bundesrepublik Deutschland. $19^{\text {th }}$ edition. C. F. Müller GmbH, 1993.

33 Ibid. In the interpretive process, it is suggested to pay attention to constitutional unity, practical concordance, functional correctness, integrative effect, and the normative power of the constitution.

34 Supra note 20, p. 18.

35 Ibid., p. 19.

36 Ibid.

37 Arshakyan M. The Impact of Legal Systems on Constitutional Interpretation: A Comparative Analysis: The U.S. Supreme Court and The German Federal Constitutional Court. German Law Journal, 2013, 1 August, No. 14, pp. 12-16.

38 Starck C. Constitutional Interpretation, in Studies in German Constitutionalism. 1995, pp. 47, 49.

39 See Magiera S. The Interpretation of the Basic Law, In Main Principles of the German Basic Law. Baden-Baden: Nomos Verlagsgesellschaft, 1983.

40 See Posner R. A. The Problems of Jurisprudence. Harvard University Press, 1990, pp. 71-123. 
thereby reinforcing their persuasive power. ${ }^{41}$ If constitutional interpretation leads to different results, it is argued that the canons should be chosen to arrive at a decision, which is coherent with the precedent in the light of its underlying value of legal certainty and predictability. ${ }^{42}$

In any case, the realist approach an important aspect to avoid undue idealisations of the law and the constitutional decision-making. The present section has highlighted the way judges arrive at their decisions through the application of elements of the common good and the canons of construction, as well as some particularities associated with the constitutional adjudication. In contrasting scenarios, where not all the interpretative methods point to the same result, the judiciary is prompted to balance the goals and the methods of interpretation in the framework of the inherent objectives of the legal order. Judges are required to display some level of judicial discretion by choosing among a number of options, none of which is predetermined to be the rights choice. Yet, in the course of interpretation, judge is still confined to give precedence to the alternative that is legal both procedurally and substantively. ${ }^{43}$

\section{Constitutional court of Georgia and its approach to statutory interpretation}

Being a part of the continental legal system, Georgia adopts a centralised model of constitutional review. Since its original setup in 1996, the Constitutional Court of Georgia has faced numerous cases with a range of comprehensive subject matters, which over time have revealed deficiencies in practice and encouraged the Court to take an active role in changing the essence of constitutional proceedings. This article intends to review a number of landmark cases from the jurisprudence of the Constitutional Court that proved to be a turning point in adopting a fresh, more practice-oriented approach towards constitutional decision-making. It is the objective of this article to demonstrate distinctive interpretative techniques and strategies that the constitutional court has been able to develop in order to ensure the effectiveness of its decisions within the framework of fundamental principles of the legal order. Indeed, application of the law in practice, as well as emerging gaps in legislative regulation have lead the Constitutional Court to introduce new approaches to statutory construction in order to help the legal 'idealism' and the 'reality' converge in practice.

\section{Constitutionality of vague legislation}

In the year of 2007, the Constitutional Court was confronted with the issue of uncertainty of law, when it had to assess the constitutionality of vague legislation.

41 Supra note 39, p. 16.

42 Ibid.

43 Barak A. Purposive Interpretation in Law. Princeton University Press, 2007, pp. 207-218. 
The case concerned ${ }^{44}$ the constitutionality of the Law on Operative-Investigatory Activity, pursuant to which, "undertaking of such an operative-investigatory activity, which limits legally protected confidentiality of communication through telephone or through other technical means, is allowed only by the order of a judge and by the resolution of a prosecutor, or on the basis of a written application of a person, who is a victim of illegal conduct, or if there is data of an illegal conduct, for which criminal code establishes imprisonment for not less than 2 years".

The claimants suggested that the norm under dispute could allow for different interpretations. The conditions, following the conjunction "or", could each be applied cumulatively with the first condition of the same norm or as independent alternatives. In the claimants' view, obligation of faithful interpretation of vagueness is an insufficient guarantee for the protection of a right.

The Court decided that the legislator is, as a general rule, under a duty to pass legislation that is foreseeable and unambiguous. The quality of a law requires that legislative regulation is so clear that an individual, whose rights are interfered with, could comprehend his or her legal situation and act accordingly.

Assessing constitutionality of vague norms, Constitutional Court should check, whether a norm, read and applied adequately to its texts and contents, could give rise to a risk of violation of a constitutional right.

Not only accuracy, foreseeability and accessibility of a law, but also the scope of permissible interference within the right must be specific and clear. This requirement is necessary for limiting and controlling the authority, as well as for protection against arbitrary interference by the state. This primarily means that the law itself should clearly and in sufficient detail define the powers of public authorities and should not allow the public authority itself to define the scope of its permissible actions. When the scope of possible interference is not defined clearly and accurately, the scope of his or her authority, the risk of abuse the power exists. Foreseeability is also important for a timely and effective judicial review. Citizens should know, in what circumstances and on the basis of what grounds their rights may be impinged upon

The Court established that there were several reasonable interpretations of disputed norm. In particular, the disputed word "or" did not comply with the requirements of foreseeability and legal certainty, as it made possible to wiretap telephone conversation and interfere into private life without court's permission, simply because the crime under investigation was punishable with imprisonment for 2 years at least.

The Constitutional Court set a standard that a legal norm can be deemed unconstitutional even if only one of its interpretations could give rise to a threat of a violation of a constitutionally entrenched right.

44 Decision of Constitutional Court of Georgia, Case: Georgian Young Lawyers Association and citizen of Georgia - Ekaterine Lomtatidze v. the Parliament of Georgia, 27.12.2007. 


\section{Foreseeability in criminal cases}

The qualitative requirement of law was discussed in another case. ${ }^{45}$ The applicants argued that the vagueness of prohibition of collection and/or transfer of any type of information to any foreign organisation, which is detrimental to the interests of Georgia according to the Criminal Code, could not comply with the criterion of foreseeability of the law, which is secured by the Constitution.

The Constitutional Court stated that the receipt and dissemination of information both at one's own initiative and by commission of another person is protected by freedom of expression. The Court recognised that the aim of imposing a punishment for transfer of information, which is detrimental to Georgia, establishes measures against being an object of foreign intelligence surveillance. However, the Court also noted that stemming from the requirements of proportionality, the right should be restricted only to the level necessary for the rule of law in a democratic society.

According to the Court, when the fact of co-operation with the intelligence of a foreign country poses the threat in itself to state security, transfer of harmless information to foreign intelligence services may cause considerable damage to state interests. Respectively, the disputed Law in the context of the prohibition of collection and transfer of information by commission of the intelligence of a foreign country represented necessary means to achieve a legitimate aim.

The Constitutional Court concluded that the disputed norm in this part was formulated with a sufficient clarity; it represented a proportionate means for restricting the right and, at the same time, did not have a 'chilling effect' upon the realisation of the freedom of expression.

As to the words 'or foreign organisations', the Court stated that the restriction with regard to the collection and transfer of information by commission of a foreign organisation had a 'chilling effect' on the freedom of expression.

The Constitutional Court ruled that adoption of a decision declaring an action as punishable is an exclusive authority of the legislator. Accordingly, the Parliament should apply this authority, so as to preclude the law enforcer, on the grounds of judicial practice, from creating itself the scope of criminally punishable actions. In the context of defining the criminal punishment of the collection and transfer of information by the commission of a foreign organisation to the detriment of the interests of Georgia, the disputed Law could be interpreted so widely that it gave an opportunity for the ordinary court, at its own discretion, to define co-operation, according to which foreign organisation should be 'detrimental to the interests of Georgia.' Accordingly, the Constitutional Court declared unconstitutional the words 'or foreign organisation'

Laws establishing criminal responsibility may open the possibility of being interpreted by the courts and the prospect of applying the law to a specific situation. Although

45 Decision of Constitutional Court of Georgia, Case: Citizens of Georgia - Alexandre Baramidze, LashaTughushi, Vakhtang Khmaladze and Vakhtang Maisaia vs. the Parliament of Georgia, 14.05.2013. 
it is impossible that a law could envisage each aspect of all the future concrete cases or situations, the legislator, while defining prohibited acts in criminal legislation, is obliged to adopt a norm, which as much as possible reduces the potential for courts to establish different legal consequences within the scope of their interpretative role.

\section{Narrowing down to the normative content: Deconstructing legal norm}

Since Georgia adopts the concentrated constitutional review model, inconsistency and divergence between the practice of the ordinary judiciary and the constitutional court can be noticeable. Such a reality is natural in a system, where two courts co-exist in the single legal system; yet, as it has already been underlined above, the difference between interpretative practices of the two court systems has to be reconcilable, otherwise the high objectives of the common good might suffer.

Such a disparity was seen to be growing when the Constitutional Court of Georgia decided to change its approach towards constitutional evaluation of a legal norm. Even though the Constitutional Court, when construing a norm, was not required to take into account the interpretation of the common courts, it began to give the common courts' interpretation an utmost account. It was believed that ordinary judiciary, whilst considering actual cases, were better served to effectuate legal norms in practice by giving them particular meaning. This meaning then ought to be assessed by the Constitutional Court as a substance of the norm in question, as it did not need to go on with its own interpretation. In case it did so, this might have caused the Constitutional Court to interpret a law differently from the ordinary judiciary and adopt a decision, which could hardly be enforceable in practice. As individuals petitioning the Constitutional Court are directly interested in obtaining an effective remedy out of their claim, ignorance of common courts' interpretative practice would have made the constitutional justice, and especially its individual complaint mechanism inapt. The Constitutional Court has moved on to change the process of assessing the constitutionality by defining a particular normative content problematic to the complainant within the disputed law and passing it on the merits.

More specifically, the Constitutional Court of Georgia has developed a narrow approach towards the complainant's claim by encouraging constitutional review to become succinct and more problem-oriented. This approach is widely manifested in the relatively recent case law of the Constitutional Court. For example, the 2013 case $^{46}$ concerned the 5-year timeframe for reopening the case under newly found circumstances. When analysing the legislation in question systematically, along with the facts at hand, the Constitutional Court concluded that the individuals who happen to be in equivalent condition as the complainants were able to take advantage

${ }^{46}$ Decision of Constitutional Court of Georgia, Case: Citizens of Israel - Tamaz Janashvili, Nana Janashvili and Irma Janashvili vs. Parliament of Georgia, 5.11.2013. 
of the rights disputed in the case. The Court went on to assess constitutionality of the impugned provision only with respect to this category of individuals.

In general, it is certainly of practical importance for the constitutional review to be closer to the specific problems outlined by the complainant(s). Due to its abstract character, normative act involves a number of precepts, rules of conduct that are difficult to identify and consider on merits. Thus, it seems reasonable for the Constitutional Court to evaluate particular normative meaning of the law that is disputed by the complainant, yet right definition of the legal norm is a challenging task. The Constitutional Court has to determine the normative content of the disputed law in order to judge upon the level of interaction between the identified legal norm and the relevant constitutional provision. As it has already been emphasised in the article, this technique becomes greatly pertinent in the countries, where the ordinary judicial system is not confined to taking into account the interpretations of the constitutional court and it effectively results in actual divergence between the two court systems regarding the meaning (content) of law.

The constitutional courts in such scenario are left basically with two options: to construe the legal norm autonomously by disregarding the practice of general courts; or to give the utmost account of the case law of the ordinary judiciary, to adopt their reading of the norm, when interpreting the substance of the impugned law and, subsequently, to rule upon its constitutionality.

Under the first approach, the constitutional court acts as a separate tribunal and does not consider interpretations made by the courts of general jurisdiction. This prompts the constitutional court to adopt an interpretative decision, whereby the constitutional court outlines the ways of interpretation of the law in question that would be compatible with the constitution and vice versa - indicating the interpretation(s) that are unconstitutional and could not be applied in practice. It is argued that such an approach serves the purpose of protecting legislative acts, which by substance are consistent with the constitution, despite being applied incorrectly by general courts in practice. It also illustrates the respect for legislator not to strike down laws that are substantively viable, as the constitutional court tends to realise the presumption of constitutionality.

Nonetheless, interpretative decisions are not proved to be effective in practice. Interpretations made by the constitutional court happen to be executed, when courts of general jurisdiction voluntarily refer to the constitutional case law in their decision-making. If the ordinary courts disregard the constitutional court's decision, the latter is left with no effective powers to ensure that its interpretation of the law is implemented. This is the case in Georgia, where the legal system does not provide efficient mechanisms for the constitutional court to force its decisions in practice. Inconsistence in the reading of the legal norm contributes to creating legal uncertainty in the system, since the subjects of law may find themselves unsure of which interpretation to follow.

As regards the other approach, the constitutional court follows the interpretation made by general court and, based on that normative substance, deliberates on its 
constitutionality. In this case, the constitutional court is inclined to adopt reading of the law as made by ordinary judiciary in order to move from an abstract review of case closer to the practical meaning of the legal norm. Thus, it follows that risk of legal uncertainty is significantly reduced and decisions of the constitutional court effective in practice.

Analysis of the case law of the Constitutional Court of Georgia indicate that initially it was oriented towards the first approach of autonomous interpretation, yet, over time, the latter method of statutory construction gained much prevalence. The Constitutional Court has reviewed a number of cases during the early stage of its existence, when it adopted the approach of interpreting the law in question independently of ordinary judiciary. It was argued that the analysis of practical application of the norm does have only subsidiary purpose. In one early case, ${ }^{47}$ the Constitutional Court indicated that tax authorities, as well as general courts made a wrong interpretation and moved on to construe the disputed law on its own. More specifically, the Court noted: "When the position of the Constitutional Court is clear with respect to the substance of the norm, then determination of particular cases of its application in practice will prompt the Constitutional Court to overstep the scope of its competence. The Constitutional Court is only empowered to assess constitutionality of the provision in question. Yet if practical application of the norm in reality is incompatible with its substance, then violation of the complainants' rights is caused not by the meaning (substance) of the norm but by its practical realisation. The Constitutional Court is not able to review practical application of the disputed norm."

As mentioned above, this interpretative approach is flawed due to several reasons. It lacks an effective mechanisms for proper implementation in practice, since there are no self-executing legislative guarantees in place, e.g. when declaring the norm unconstitutional, it automatically results in annulment (invalidation) of the provisions in question, and ordinary courts have to abide by the argumentative part of the constitutional court's decision. However, this issue proved to be the subject of contention between the ordinary judiciary and the Constitutional Court in Georgia. It has been argued that, because the law prescribes judges of the courts of general jurisdiction to base their decisions upon the Constitution and law, it thus follows that there is no legal requirement for the ordinary judiciary to abide by the argumentative part of the Constitutional Court's decision. In other words, legal evaluation made by the Constitutional Court does not qualify as a law or a part of the Constitution, and thus general courts are not constrained to apply it in practice.

This rationale turned out to be predominant in Georgia, as ordinary courts did not pay much attention to the jurisprudence of the Constitutional Court, which effectively risked that the constitutional review mechanism would be left impotent. Against this backdrop, the Constitutional Court of Georgia decided to change its approach by applying different interpretative perspective in order to move

47 Ruling of Constitutional Court of Georgia, Case: Citizen of Georgia Nino Burjanadze vs. Parliament of Georgia, 22.03.2010. 
closer to a concrete review model. More specifically, the Court started to consider interpretations made in general court system as an integral part of the substance of the legal norm. In addition, this approach has encouraged the Constitutional Court to embark upon a narrow reading of the law in question by rejecting exhaustive, allencompassing deliberation regarding its constitutionality and address only the claims brought forward by the complainants.

In a landmark case, ${ }^{48}$ the Constitutional Court decided to invalidate the normative content of the legal provision that was questioned by the complainant. Under the disputed, every citizen were obliged to serve in military reserve force, and it was argued by the complainant that it contradicted the Constitution on the account of including conscientious objectors in the military reserve list. The Constitutional Court deconstructed the disputed provision and went on to evaluate constitutionality of the particular normative content, rather than reviewing the legal norm as a whole. The Court displayed restraint by not striking down the provision, which would clearly solve the complainant's problem, but went beyond the complaint by unnecessarily damaging constitutionally compatible legislative agenda (that military reserve has to exist with respect to other citizens).

Lately, the Constitutional Court considered another significant case, ${ }^{49}$ which concerned internet surveillance law. The complainant argued that the law in question allowed authorities to monitor internet communication in a secret manner, so that individuals communicating with each other were not aware of such surveillance. Notably, the disputed law provided for two ways of monitoring internet communication - open and closed. The Court went on to define problematic part of the law in question by evaluating complainant's arguments and concluded that with respect to closed internet communication, surveillance lacking the court warrant is unconstitutional. It thus follows that the Constitutional Court again invalidated the normative content of the impugned law by applying restrictive interpretation of the law that proved to be pertinent to practical reality.

When deconstructing the normative content of the law and passing on its constitutionality, the Constitutional Court assesses the law as a combination of rules in essence. The Court no longer deems an impugned legal norm as a textual substance, which can either be invalidated or left in force. Rather, it is important to identify concrete rule(s) of conduct within a disputed norm problematic for the complainant and decide on the constitutionality thereof. Certainly, the jurisprudence of the ordinary judiciary gains a great relevance in the constitutional proceedings, since consideration of the constitutional case in line with interpretations made by general courts is more likely to give the complainant a chance to seek an effective remedy provided the legal norm is found unconstitutional.

48 Decision of Constitutional Court of Georgia, Case: Public Defender of Georgia vs. Parliament of Georgia, 22.12.2011.

49 Decision of Constitutional Court of Georgia, Case: Georgian Young Lawyers Association and Citizen of Georgia Tamar Chugoshvili vs. Parliament of Georgia, 24.10.2012. 
The Constitutional Court has expounded its revamped strategy of interpreting a law in line with ordinary judiciary in its recent case. ${ }^{50}$ It was observed that "[w]hen determining the substance of the disputed norm, the court alongside other factors accounts for practical applicability of that norm. The courts of general jurisdiction, within their competence, decide on the normative content of the law, its practical applicability, and accordingly, its execution. It follows that interpretation made by the general courts are greatly important in defining the actual substance of the law. The Constitutional Court considers a legislative norm in line with the normative meaning as it has been applied by the general courts. Although there may exist several exceptions from this rule; namely, when the Constitutional Court concludes that interpretations made by the general courts of the same level is contradictory. In this case it must not be assumed that the general courts have finally established the meaning of the disputed law. In addition, different interpretative results of the norm may indicate to the vagueness and unconstitutionality of the norm. Apart from this, the Constitutional Court is still empowered not to abide by the interpretation of the general courts provided it is clearly unreasonable."

This new approach to interpretation ensures that the Constitutional Court decisions are effectively enforced in practice and claimants get a proper redress. It also helps to avoid creating a gap in legislation. More specifically, when the Constitutional Court finds the legislative act unconstitutional, it results in invalidation of that act as a whole, even when some aspects of its interpretation or implementation are in line with the constitution. Accordingly, the elimination of a particular legal provision leaves a certain gap, requiring legislative action. In contrast, when the Constitutional Court invalidates specific normative substance of the disputed law, it causes the impugned provision to remain in force, except for the specific meaning that was declared unconstitutional.

\section{Emerging gap in legislation and the constitutionality of legislative institution}

In a relatively recent case, the Constitutional Court had a complex task to assess the constitutionality of the number of legislative provisions related to the rights of persons with mental disabilities. Specifically, the challenged issue, inter alia, consisted of the following:

a. Restricted persons recognised as incapable due to their 'imbecility' or mental illness, in their freedoms to willingly and actively acquire civil rights and responsibilities;

b. Abolished acts of persons, who were recognised as incapable;

c. Banned persons, who were recognised as incapable, from the right to marry;

50 Decision of Constitutional Court of Georgia, Case: JSC Liberty Bank vs. Parliament of Georgia, 4.03.2015, paragraph II-11. 
d. Declared legal representatives as the persons' lawful representatives empowered to represent the subject of their guardianship with third parties without a specific appointment (e.g., courts) and entitled to sign every necessary deal on behalf of persons recognised as incapable.

The Court determined that the provision, which annulled every single transaction negotiated by a mentally disabled person (including the transactions that benefited these persons), vividly trespassed the aim to defend the persons with mental disorders, and the restrictions were disproportionate.

The Court indicated that the existing normative approach to disorder completely ignored the reality that the limitation of mental disorders is characterised by the wide-ranging gradations and fragmentation of limiting the ability of persons with mental disorders to comprehend the results of their actions to a varying degree. The disputed norms, however, were applied to all persons recognised as mentally incapable, and took away from them the possibility to realise those capacities, which they did still have in their possession. An optimal mechanism to recognise a person as incapable should allow a court to consider the damage on the decisionmaking capacity of a person with mental disorders and must ensure as much as possible that the rights and freedoms of this person are protected. Furthermore, the purpose of guardianship lies in supporting the person in the decision-making process and not in substituting their will in every sphere of life. Therefore, it was determined that the disputed norms disproportionately restricted the right to free development of personality of the persons recognised as incapable, and were declared unconstitutional with regards to the right to free development of the Constitution. Civil Code prohibited marriage, if one of the future spouses was recognised as incapable. The Court stressed that the disputed norms prevented them to turn cohabitation with a partner into a legal recognition of their voluntary union. According to the Court, if a person has social skills to understand non-material results that accompany a marriage, then taking away the right to marry, disregarding individual mental capacities, represents a disproportionate interference in the right. State may use the least restrictive mechanism to protect their right to property by allowing marriage through the consent of legal representative or a respective body.

As a result of the aforementioned decision, the Court has mastered an intrinsically novel approach to postpone the execution of its decisions, if invalidation of the disputed law would cause serious damage. ${ }^{51}$ The Court stated that immediate annulment of legal norms regulating the status of mentally incapacitated persons would leave the persons concerned, as well as the legal institute at large mostly unregulated. The Court postponed the invalidation of the disputed law for 6 months. The Court thereby compromised to allow an existence of unconstitutional legal norms in practice, in order to avoid graver damage by giving the legislator reasonable time to prepare necessary changes stated in the decision.

51 Decisions of Constitutional Court of Georgia, Cases: Citizens of Georgia David Kharadze and Irakli Kemoklidze vs. Parliament of Georgia, 8.10.2014; see also, Citizens of Georgia Valerian Gelbakhiani, Mamuka Nikolaishvili and Aleksandre Silagadze vs. Parliament of Georgia, 13.11.2014. 
In addition to the interpretative approaches of the Constitutional Court of Georgia, it has moved to decide cases, in which the complainant disputed constitutionality of a particular legal institution due to the fact that the existing regulatory framework was uncertain and unconstitutional. Claimant challenged constitutionality of provision of the Criminal Procedure Code, which allowed suspension from office of an official elected by secret, universal, equal and direct suffrage [Mayor]. ${ }^{52}$ As a coercive measure, the suspension might have been used, if the official was charged with a criminal offence and a threat existed that his/her continued occupation of the office would obstruct investigation, or commit a new crime.

The Court stated that, despite a legitimate aim, the duration of the suspension without strict time frames until the final judgement and, therefore, for indefinite time, is decisive with regard to elected officials, since their time to serve in an office is strictly determined, and it will objectively be impossible to make up for the lost time and to return to office. Occupation of the said office is solely permitted to persons elected directly by citizens in regular elections for a strict time limit of 4 years without prolongation via secret, universal, equal and direct suffrage,

Therefore, the Court concluded that the suspension of a high-level official for an indeterminate duration may be effectively equal to a dismissal. The legislation did not stipulate the mechanisms to allow the concerned individual to review this temporary measure until the final court judgement is adopted, even if there is no objective basis to let it continue.

The Court thereby declared unconstitutional the suspension rule of elected local officials from the office on the account of deficiency, vagueness and omission in procedural guarantees that could have led to an unjust temporary dismissal of an elected official. However, the Court has indicated that the suspension procedure of elected individuals is not per se unconstitutional; rather, its regulatory framework does disable this legal institution to meet constitutional requirements. It thus follows that, in certain cases, when specific areas or procedures are not regulated or are intentionally omitted, this may a priori render a constitutional legal institution invalid due to uncertainty and vagueness of those rules, under which it functions.

\section{Conclusion}

This article reviewed the relevant case law of the Constitutional Court of Georgia in order to illustrate, how the Court has transformed its approach in an effort to effectuate its decisions in practice. It was the particular purpose of this paper to highlight the evolution of the interpretative case law of the Georgian Constitutional Court within the remit of the positivist understanding of common good of the whole legal system.

The article initially sketched the theoretical discussions regarding the essence of constitutional review and the challenges associated with its proper functioning.

52 Decision of Constitutional Court of Georgia, Case: Citizen of Georgia Giorgi Ugulava v. Parliament of Georgia, 23.05.2014. 
A special focus was directed at the need of effective institutional dialogue between the ordinary judiciary and the constitutional court to ensure smooth operation of the constitutional order. There is no obvious relation between the review of legislation in the abstract and the work of regular courts. However, given the importance of the constitutional justice, creative techniques have been developed in jurisprudence to achieve influence over the ordinary judges. ${ }^{53}$ It was emphasised that constitutional courts have developed distinctive interpretative strategies beyond their ordinary procedure, yet within the boundaries of law, to ensure that the individuals applying to the constitutional court are able to get a proper redress. The article proceeded to briefly review the theoretical foundations of law and order, as well as the various elements of law, which are presupposed to integrate with each other, but in fact they may well be mutually contradictory. It follows that the judiciary, along with legislature, has the exclusive power to rectify errors in legislation and ensure that laws are interpreted as willed by legislator, still bearing in mind the practical implications of its operation.

The next section of the article moves on to the discuss the cases from Georgian experience. Namely, a number of landmark cases are presented that illustrate the attempts by the Constitutional Court to bring in new interpretative techniques in order to ensure that the constitutional justice remains close to reality and has viable prospects of full enforceability. More specifically, the Constitutional Court developed the evaluative standard for normative content, whereby the Court acts to narrow down the disputed provision to the normative content (the substance of the specific rule of the law) that is relevant for the complainant. This approach has helped the Constitutional Court to encourage constitutional rights and freedoms to have a meaningful effect in ordinary legal cases, as well as to ensure that the constitutional justice is an effective remedy for individual petitioners.

\section{BIBLIOGRAPHY}

\section{Literature}

\section{Monographs}

1. Alexy R. A Theory of Legal Argumentation: The Theory of Rational Discourse as Theory of Legal Justification. Oxford University Press, 2009.

2. Barak A. Purposive Interpretation in Law. Princeton University Press, 2007.

3. Hart J. E. Democracy and Distrust: A Theory of Judicial Review. $1^{\text {st }}$ edition. Harvard University Press, 1980.

4. Hesse K. Grundzüge des Verfassungsrechts der Bundesrepublik Deutschland. $19^{\text {th }}$ edition. C. F. Müller GmbH, 1993.

5. Kelsen H. General Theory of Law and State, 1945.

6. Magiera S. The Interpretation of the Basic Law. In: Main Principles of the German Basic Law. Baden-Baden: Nomos Verlagsgesellschaft, 1983.

53 See: Garoupa N., Ginsburg T. Building Reputation in Constitutional Courts: Political and Judicial Audiences. Arizona Journal of International and Comparative Law, 2011, No. 28. 
7. Nonet P., Selznick P. Law and Society in Transition: Toward Responsive Law. Transaction Publishers, 2001.

8. Posner R. A. The Problems of Jurisprudence. Harvard University Press, 1990.

9. Sadurski W. Rights before Courts: A Study of Constitutional Courts in Postcommunist States of Central and Eastern Europe. $2^{\text {nd }}$ edition, Springer, 2005.

10. Starck C. Studies in German Constitutionalism, 1995.

11. Stone A. The Birth of Judicial Politics in France: The Constitutional Council in Comparative Perspective. $1^{\text {st }}$ edition. New York: Oxford University Press, 1992.

\section{Articles}

12. Arshakyan M. The Impact of Legal Systems on Constitutional Interpretation: A Comparative Analysis: The U.S. Supreme Court and The German Federal Constitutional Court. German Law Journal, 2013, 1 August, No. 14.

13. Brugger W. Concretization of Law and Statutory Interpretation. Tulane European and Civil Law Forum, 1996, No. 11.

14. Donato J. Dworkin and Subjectivity in Legal Interpretation. Stanford Law Review, 1988, July, No. 40.

15. Ferreres Comella V. The European Model of Constitutional Review of Legislation: Toward decentralization? International Journal of Constitutional Law, 2004, 1 July, No. 2(3).

16. Garlicki L. Constitutional Courts versus Supreme Courts. International Journal of Constitutional Law, 2007, 1 January, No. 5(1).

17. Garoupa N., Ginsburg T. Building Reputation in Constitutional Courts: Political and Judicial Audiences. Arizona Journal of International and Comparative Law, 2011, No. 28.

18. Ginsburg T. And Elkins Z. Ancillary Powers of Constitutional Courts. Texas Law Review, 2009, June, No. 87.

19. Hessick F. A. Rethinking the Presumption of Constitutionality. Notre Dame Law Review, 2010, June, No. 85.

20. Wright Sheive S. Central and Eastern European Constitutional Courts and the Antimajoritarian Objection to Judicial Review. Law and Policy in International Business, 1995, No. 26.

\section{Legal practice}

1. 34 BVerfGE 269, 288 (F.R.G. 1973)

2. 79 BVerfGE 106, 121 (F.R.G. 1988).

3. 9 BVerfGE 338, 349 (F.R.G. 1959).

4. Decision of Constitutional Court of Georgia, Case: JSC Liberty Bank vs. Parliament of Georgia, 4.03.2015.

5. Decision of Constitutional Court of Georgia, Case: Citizen of Georgia Giorgi Ugulava v. Parliament of Georgia, 23.05.2014.

6. Decision of Constitutional Court of Georgia, Case: Citizens of Georgia David Kharadze and Irakli Kemoklidze vs. Parliament of Georgia, 8.10.2014.

7. Decision of Constitutional Court of Georgia, Case: Citizens of Georgia Valerian Gelbakhiani, Mamuka Nikolaishvili and Aleksandre Silagadze vs. Parliament of Georgia, 13.11.2014. 
8. Decision of Constitutional Court of Georgia, Case: Citizens of Israel - Tamaz Janashvili, Nana Janashvili and Irma Janashvili vs. Parliament of Georgia, 5.11.2013.

9. Decision of Constitutional Court of Georgia, Case: Georgian Young Lawyers Association and Citizen of Georgia Tamar Chugoshvili vs. Parliament of Georgia, 24.10.2012.

10. Decision of Constitutional Court of Georgia, Case: Public Defender of Georgia vs. Parliament of Georgia, 22.12.2011.

11. Judgement of European Court of Human Rights, Case No. 40765/02 Apostol vs. Georgia.

12. Ruling of Constitutional Court of Georgia, Case: Citizen of Georgia Nino Burjanadze vs. Parliament of Georgia, 22.03.2010.

\section{Other sources}

1. Barroso L. R. The Roles of Supreme Courts and Constitutional Courts in Contemporary Democracies. Available at http://www.iconnectblog.com/2016/10/the-roles-of-supremecourts-and-constitutional-courts-in-contemporary-democracies [last viewed October 21, 2016].

2. Paczolay P. Introduction to the Report of the Venice Commission on Individual Access to Constitutional Justice. In: Conference "Individual Access to Constitutional Justice”. Arequipa, Peru, 2013.

3. Study on Individual Access to Constitutional Justice by the Venice Commission. CDL-AD(2010)039rev. Adopted at the 85 ${ }^{\text {th }}$ Plenary Session on 17-18 December 2010. 
Daiga Rezevska, Dr. iur.

University of Latvia, Latvia

\title{
IDEOLOGY, VALUES, LEGAL NORMS AND CONSTITUTIONAL COURT
}

\begin{abstract}
Summary
The article deals with the meanings and distinction between the terms "values", "general principles of law" and "written legal norms", as well as the relation of the terms to the meaning of the constitutional identity of the given state and its legal arrangement. There are two types of values, which are enshrined in the constitutional identity of the given country: 1) the values, which are historically and culturally connected with the given sovereign; 2) the values, which are introduced into the legal arrangement by the basic norm (for example, a basic norm - democratic, rule of law-based state). The values are not legal norms, but they are the reasons why the legal norms exist. Firstly, values are protected by the unwritten legal norms - general principles of law, which are derived from the basic norm - democratic state based on the rule of law. Then, they are protected also by the written legal norms concretized from the general principles of law and adopted by the legislature. Ideology provides the basis for the assumption of the basic norm and belief in it of those who apply legal norms, andserves as an educational basis for the sovereign to apprize and use legal arrangement. The role of the constitutional court in this process is crucially important.
\end{abstract}

Keywords: values, general principles of law, constitutional identity, Constitutional Court.

\section{Introduction}

The central issue of this paper is to discover and detect the meaning, distinction between and logical legal sequence of the terms "values", "general principles of law" and "written legal norms", as well as the relation of the terms to the meaning of the constitutional identity of the given state and its legal arrangement.

The comparative and historical methods are used to analyse the interdependence of the terms "values" and "general principles of law", as well as to assess the historical role of the Constitutional Court of the Republic of Latvia in developing and transforming of the legal arrangement. The deductive method is used to show the development from the value to the general principle of law and consecutively to the written legal norm. Inductive method, in turn, helps to analyse the work of the court in interpreting the written legal norm by taking into account and safeguarding the values. Finally, systemic method is applied to determine the place and role of each of the phenomena within the legal arrangement. 


\section{The meaning of values}

When we speak about the values, we usually hear or read terms like life, human dignity, justice, family, freedom of expression, or thoughts, or choice, equality, democracy, human rights, rule of law, or even free market. But, at the same time, it is often also stated that equality or democracy, or rule of law are general principles of law. Thus, the terms "values" and "principles" in the modern legal theory seem to lack very sharp and precise borders for the distinction; to be absolutely clear, sometimes these terms are even used interchangeably. Nevertheless, there are certain and definable criteria to separate the terms in order to reflect their true legal nature, as well as the difference in the application while interpreting the constitutions.

The values have a culturally determined meaning providing each value with a particularistic significance that effectively severs the idea of values from any universalistic claims. ${ }^{1}$ To prove this statement, the authors usually refer to the texts of the constitutional documents, which, in their turn, refer to the values and the emphasis on the history and tradition. In these constitutional settings, judges must be attentive to societal values that are embedded in a nation's long standing traditions, and use them as a significant tool in the process of constitutional interpretation.

No single and unified definition yet exists for the term "constitutional identity"; various authors place under the constitutional identity a wide range of concepts from focus on the actual features and provisions of the constitutions (unitary or federal state, presidential or parliamentary system, ext.) to the relation between the constitution and the culture in which it operates, and to the relation between the identity of the constitution and other relevant identities, such as national, religious, or ideological identity. ${ }^{2}$

It should be taken into account that constitutional identity cannot be reduced only to the written text of the Constitution. The elements of the constitutional identity are reflected in many sources - the written Constitution, other laws and regulations and other documents of non-normative effect, as well as in the unwritten general principles of law and values. ${ }^{3}$ The concept of the constitutional identity actually widens the scope of the Constitution, as the constitutional norms insinuate into the issues of the social values and political ideology. Therefore, references to the state's (nation's) history, traditions, language, conditions of the establishing

Jacobson G. J. Constitutional Values and Principles. The Oxford Handbook of the Comparative Constitutional Law. Rosenfeld M., Sajo A. (eds.). Oxford: Oxford University Press, 2012, p. 785.

2 Rosenfeld M. Constitutional identity. The Oxford Handbook of the Comparative Constitutional Law. Rosenfeld M., Sajo A. (eds.). Oxford: Oxford University Press, 2012, pp. 756-757.

3 On the Constitutional Foundations of the State of Latvia and the Inviolable Core of the Constitution. Opinion of the Constitutional Law Commission. 17 September 2012. Available at http://www.president.lv/images/modules/items/PDF/17092012_Viedoklis_2.pdf, para. 163 [last viewed July 7, 2016.]. 
and development of the country are "encoded" (directly or indirectly) in the constitutions. ${ }^{4}$

The Preamble of the Constitution of the Republic of Latvia (Satversme) clearly reflects those values, which are the basis of the constitutional identity of Latvia. ${ }^{5}$ Among others, it states:

"Latvia as a democratic polity based on the rule of law is a socially responsible and national state; it is founded on respect for human dignity and freedom, recognises and safeguards fundamental human rights and respects its national minorities. The people of Latvia protect their sovereignty as well as the independence, territory, unity and democratic form of government of the State of Latvia.

Since times immemorial, Latvia's identity within the European cultural sphere has been shaped by Latvian and Liv customs, the traditional Latvian folk wisdom and moral convictions, the Latvian language as well as universal human and Christian values. Loyalty to Latvia, Latvian as the only official language, freedom, equality, solidarity, justice, honesty, and the ethos of work and family are the foundations of a cohesive society. Everyone provides for oneself, one's relatives and the common good by acting responsibly towards other people, future generations, the environment and nature." 6

However, looking at the abovementioned types of values, seemingly appears a difference between values like traditional Latvian folk wisdom or Christian values and, for example, rule of law or socially responsible state. Taking into account the abovementioned, it has to be concluded that there are two types of values and both of them are enshrined in the constitutional identity of the given country:

1) the values, which are historically and culturally connected with the given sovereign;

2) the values, which are introduced into the legal arrangement by the basic norm - democratic state based on the rule of law.. ${ }^{7}$

Furthermore, the interrelation between the enforcement of the rule of law in the legal arrangement and the historical and cultural values of the given sovereign

Pleps J. Baltijas valstu konstitucionālā identitāte (Constitutional Identity of the Baltic States). Jurista Vārds, 2016, No. 34.

5 Compare: Birmontiene T. Konstitūcija ir mūsu Bībele (Constitution is our Bible). Intervija. Jurista Vārds, 2015, No. 26.

6 The Preamble of the Constitution of the Republic of Latvia (Satversme). Available at http:// www.saeima.lv/en/legislation/constitution [last viewed July 16, 2016].

7 For example, the Constitutional Court has recognized that: "The State of Latvia is based on such fundamental values that, among the rest, include basic rights and fundamental freedoms, democracy, sovereignty of the State and people, separation of powers and Rule of law. The State has the duty to guarantee these values and they cannot be infringed by introducing amendments to the Satversme, or by adopting the law." These are the values introduced into the legal arrangement by the basic norm - democratic Rule of law based state. Judgement of the Constitutional Court of the Republic of Latvia in Case No. 2008-35-01 on April 7, 2009, para. 17. Available at http://www.satv.tiesa.gov. lv/wp-content/uploads/2008/09/2008-35-01_Spriedums_ENG.pdf [last viewed August 12, 2016]. 
can be detected. Very clearly it can be seen in the situations with the so-called "legal transplants". For example, if the legal arrangement of the democratic state based on the rule of law is "transplanted", then, if the historical and cultural values of the sovereign are closely related to the democracy and rule of law, the transplant "survives" and is generally accepted by the sovereign. However, if the sovereign's historical and cultural values are notably different, the transplant is not successful.

\section{General principles of law}

The values, which are historically and culturally connected with the given sovereign, serve as the basis for the sovereign when expressing its will in the form of the basic norm. Sovereign's will, in other words, defines the content of the basic norm, it speaks to the type of country in which the sovereign wishes to live. ${ }^{8}$ When sovereign's will is formulated in a basic norm, the legal arrangement in the relevant country is governed by principles emanating from that norm. In case of a democratic state based on the rule of law, these are a specific source of law called general principles of law. In deciding to create a democratic state based on the rule of law, the sovereign cannot affect the existence and content of these general principles of law. ${ }^{9}$ These principles alongside the values form the constitutional identity of the given country. General principles of law define the content and structural elements of the legal arrangement of the relevant country and are real and directly applicable legal norms consisting of legal content and legal consequences, and having generally binding effect.

Thus, the historical and cultural values serving as a fundament for pronouncing of the basic norm, as well as the values introduced by the basic norm, need to be protected by law. Law, which consists of unwritten legal norms in the form of general principles of law and, consequently, the written legal norms concretised from the general principles of law and adopted by the legislature. Accordingly, the values are the basis of law, the aim of law is to protect them. ${ }^{10}$

8 The basic norm for Latvia's legal arrangement was formulated in the declaration of independence which was prepared by the Latvian People's Council and approved on November 18, 1918. Because the People's Council was not an institution legitimated by a democratic process, the Latvian Constitutional Convention reaffirmed the basic norm on May 27, 1920, in its "Declaration on the Latvian State”. See: Pleps J. Normativo tiesību aktu hierarhija: profesors Hanss Kelsens un mūsdienas (I) (The Hierarchy of Acts of Legal Norms: Professor Hans Kelsen and the Present Day). Likums un Tiesības, Vol. 8, No. 2(78), 2007, pp. 90-91.

9 If the basic norm specifies a different structure of state or political regime, then other principles will apply to the content and structure of that country's legal arrangement For instance, the so-called "leader principle" is unacceptable in a democratic country, but it is an applied principle in the legal arrangement of the authoritarian country. Ibid., p. 90. See also: Kalniņš E. Tiesību normas spēkā esamība un intertemporālā piemērojamība (The Validity and Intertemporality of a Legal Norm). Likums un Tiesíbas, Vol. 7, No. 2(11), 2000, p. 216.

10 Grigore-Bāra E. Pienākums teikt patiesību primāri būtu jāsaprot kā aizliegums melot (Obligation to Say the Truth Primarily Would be Understood as Prohibition to Lie). Jurista Vārds, 2015, No. 30. 


\section{Ideology}

Ideology is a collection of opinions and beliefs held by an individual, group or society and that guides them. ${ }^{11}$ It is a system of ideas and ideals, which form the basis of the theory, in our case, we speak about the theory of a democratic state based on the rule of law. It is very important to acknowledge that a common ideology a common system of beliefs in the given society - is crucial for protection of democracy and the rule of law. And it applies both to the sovereign and to those who apply legal norms.

Where does the validity of the basic norm rest? The validity of the basic norm rests in the assumption of persons applying the law. The assumption of the basic norm is an assurance in the legal mind or consciousness of the mandate and righteousness. The basic norm makes those, who apply legal norms, feel safe and faultless, when they are acting in the framework of the mandate. Furthermore, it is not enough to know the basic norm, the one who applies law has to believe in it. ${ }^{12}$

The ideology held by the sovereign primarily repose on its historical and cultural values, which connect with the values introduced by the basic norm. However, on the other hand, the ideology of the democratic state based on the rule of law needs to be promoted and popularized to the sovereign..$^{13}$ Education is very important in this regard, and extremely significant is the so-called educational function carried out by the constitutional court of the given legal arrangement.

We all have heard the saying that the legal arrangement is as strong and as successful as its constitutional court. The role of the constitutional court in the developing and maintaining the democratic legal arrangement based on the rule of law cannot be overrated. And we, the people of Latvia, can be regarded as lucky, because the country's Constitutional Court is open minded and ready to apply unwritten legal norms - general principles of law - even in its first judgment. ${ }^{14}$ The author dares to insist that this first judgment of the Constitutional Court of Latvia delivered almost 20 years ago accelerated the development of Latvia's legal progress towards democratic state based on the rule of law, governed by the legal understanding on the basis of natural law doctrine. Of course, one can argue that the legal arrangement would have come down this path anyway, but certainly not as fast and not in such a quality as enjoyed by people today.

11 Compare: The Definition of Ideology. Merriam-Webster Dictionary. Available: https://www. merriam-webster.com/dictionary/ideology [viewed 2016. 7 July]; English Oxford Dictionary. Available at https://en.oxforddictionaries. com/definition/ideology [last viewed July 7, 2016].

12 See similarly: Gardner J. Law as a Leap of Faith. Oxford University Press, 2012. p. 15.

13 Especially in the above mentioned cases of legal transplants.

14 The Constitutional Court stated: "In conformity with general principles of law, legislative acts are considered invalid: 1) if the termination of authority or any other condition that restricts the act has set in; 2) if the legislative act is deleted or 3) if another legislative act, settling the very same issues and with the same or higher force of law has been passed." Judgement of the Constitutional Court of the Republic of Latvia in Case No. 04-01(97) on May 7, 1997, para. 2. Available at file://C:/ Users/LU\%20JF/Downloads/04-0197_spriedums.pdf.pdf [last viewed August 12, 2016]. 


\section{Conclusion}

1. There are two types of values, which are enshrined in the constitutional identity of the given country:

1) the values, which are historically and culturally connected with the given sovereign;

2) the values, which are introduced into the legal arrangement by the basic norm - for example, a democratic state based on the rule of law.

2. The values are not legal norms, but they are the reasons why the legal norms exist in the legal arrangement and namely - to protect these values. It leads to the next conclusion - that the aim of the legal norms is to be applied in such a manner that protects the values in the best possible way.

3. Ideology is a system of opinions and beliefs, which serves for protection of democracy and the rule of law. On the one hand, by providing the basis for the assumption of the basic norm and belief in it of those who apply legal norms, on the other hand - by serving as an educational basis for the sovereign to apprize and use the legal arrangement. The role of the Constitutional Court in this process is crucially important.

\section{BIBLIOGRAPHY}

\section{Literature}

1. Birmontiene T. Konstitūcija ir mūsu Bībele (Constitution is our Bible). Intervija. Jurista Vārds, 2015, No. 26.

2. Gardner J. Law as a Leap of Faith. Oxford University Press. 2012

3. Grigore-Bāra E. Pienākums teikt patiesību primāri būtu jāsaprot kā aizliegums melot (Obligation to Say the Truth Primarily Should be Understood as Prohibition to Lie). Jurista Vārds, 2015, No. 30.

4. Jacobson G. J. Constitutional Values and Principles. In: The Oxford Handbook of the Comparative Constitutional Law. Rosenfeld M., Sajo A. (eds.). Oxford: Oxford University Press, 2012.

5. Kalniņš E. Tiesību normas spēkā esamība un intertemporālā piemērojamība (The Validity and Intertemporality of a Legal Norm). Likums un Tiesíbas, Vol. 7, No. 2(11), 2000

6. Pleps J. Baltijas valstu konstitucionālā identitāte (Constitutional Identity of the Baltic States). Jurista Vārds, 2016, No. 34.

7. Pleps J. Normatīvo tiesību aktu hierarhija: profesors Hanss Kelsens un mūsdienas (I) (The Hierarchy of Acts of Legal Norms: Professor Hans Kelsen and the Present Day). Likums un Tiesības, Vol. 8, No. 2(78), 2007.

8. Rosenfeld M. Constitutional identity. In: The Oxford Handbook of the Comparative Constitutional Law. Rosenfeld M., Sajo A. (eds.). Oxford: Oxford University Press, 2012.

9. On the Constitutional Foundations of the State of Latvia and the Inviolable Core of the Constitution. Opinion of the Constitutional Law Commission. 17 September 2012. Available at http://www.president.lv/images/modules/items/PDF/17092012_Viedoklis_2. pdf, para. 163 [last viewed July 7, 2016]. 


\section{Legislative acts}

1. The Preamble of the Constitution of the Republic of Latvia (Satversme). Available at http:// www.saeima.lv/en/legislation/constitution [last viewed July 16, 2016].

\section{Legal practice}

1. Judgement of the Constitutional Court of the Republic of Latvia in Case No. 2008-35-01 on April 7, 2009, para. 17. Available at http://www.satv.tiesa.gov.lv/wp-content/uploads/ 2008/09/2008-35-01_Spriedums_ENG.pdf [last viewed August 12, 2016].

2. Judgement of the Constitutional Court of the Republic of Latvia in Case No. 04-01(97) on May 7, 1997, para. 2. Available at file:///C:/Users/LU\%20JF/Downloads/04-0197_ spriedums.pdf.pdf [last viewed August 12, 2016].

\section{Other resources}

1. The Definition of Ideology. Merriam-Webster Dictionary. Available at https://www. merriam-webster.com/dictionary/ideology; English Oxford Dictionary. Available at https:// en.oxforddictionaries. com/definition/ideology [last viewed July 17, 2016]. 


\section{SECTION 3}

\section{PROTECTION OF CONSTITUTIONAL VALUES IN CRIMINAL LAW AND CRIMINAL PROCEDURE LAW}


Andrejs Vilks, Dr. iur.

Riga Stradins University, Latvia

\title{
LEGAL PROTECTION OF VICTIMS OF CRIME IN THE CONTEXT OF CONSTITUTIONAL VALUES
}

\begin{abstract}
Summary
The aim of the article is to give an insight into legal protection of victims of criminal offenses in the aspect of constitutional legal acts and values. In the protection of victims of criminal offenses, a great importance is attributed not only to the national legal regulations, especially the Constitution, but to the international legal acts, as well. The author does not claim to give a complete and comprehensive problem analysis. The basic idea of the article deals is directed at the necessity for more consistent protection not only of any individual's rights and freedom, as defined in the Constitution, but especially at providing for those people's legal protection, who have been subject to criminal offenses. It is important not only to take supportive action, but also to grant compensation for a specific damage. In order for the victims to receive sufficient support, help and protection, the public services should coordinate their work, and become involved at all administrative levels - at the European Union level, and at the national, regional and local levels.
\end{abstract}

Keywords: crime, constitutional rights, constitutional values, law, legal system, victims.

The aim of the article is to provide an insight into legal protection of victims of criminal offenses in the aspect of constitutional legal acts and values. In the protection of victims of criminal offenses, a great importance is attributed not only to the national legal regulations, especially the Constitution, but also to the international legal acts. The author does not claim to give a complete and comprehensive problem analysis. The basic idea of the article addresses the necessity for more consistent protection, not only any individual's rights and freedom, as defined in the Constitution, but especially to provide legal protection to those people, who have been subject to criminal offenses.

With the advancement of the legal system and the increase in the importance pertaining to the rule of law, a greater attention is being paid not only to the subjects of crime - the criminals, but also to the victims of crime. The inclusion of the victims' rights into the Republic of Latvia Constitution, Chapter 8 gives evidence to the practical and theoretical significance of these rightholders. It should be mentioned that in the First Constitutional Assembly of the Republic of Latvia on February 15, 1922, as well as in its draft, no norm was included with regard to 
legal protection of participants in criminal proceedings (suspects, the accused, the defendant and the victim). ${ }^{1}$

To some extent, the aforementioned drawback was corrected in the constitutional law adopted by the Supreme Council on December 10, 1991 "Human and Civil Rights and Obligations", the Article 18 says that "Every unlawfully arrested or tried individual has a right to comprensation for the incurred material and moral damage". The content of the Chapter stipulated that in correspondence to the constitutional law, the rights were provided only for those individuals who are unlawfully submitted to penal repressions. These individuals were also the victims as a result of unlawful activities of criminal procedures. ${ }^{2}$

However, they could not be directly and to a full extent considered the victims of criminal activities, which the relevant parties had committed in line with certain Chapters of the Criminal Code and Criminal Law. This law did not include the victims who suffered from primary crimes, which limited the constitutional framework, giving them the constitutional rights to protect their rights and legal interests. Appropriate remuneration for the damage of unlawful acts is one of the elements of basic principles of the legal state. ${ }^{3}$ Only on October 15, 1998 the amendments were adopted in the Constitution by adding the Chapter VIII "Fundamental Human Rights". In the article, the author concentrates only on one of the human rights therein - the legal protection extended to the victims of crime. The problem regarding the victims of crime is addressed not only because their rights are legally protected at the highest national juridical aspect, but also because the victim is a multispectre category, which can be analyzed from the viewpoint of criminal law, criminal process, legal philosophy of criminology and other sciences. The inclusion of the victims' right in the Constitution says that individuals, whose rights are infringed most severely, suffering a significant harm, are entitled to demand the relevant renumeration on the basis of the fundamental rule.

The Article 92 of the Constitution says that "Everyone has the right to defend his or her rights and lawful interests in a fair court. Everyone shall be presumed innocent until his or her guilt has been established in accordance with law. Everyone, where his or her rights are violated without basis, has a right to commensurate compensation. Everyone has a right to the assistance of counsel." In the Article 92 of the Constitution, the category "victims of crime" is not included, but, undoubtedly, the range of these subjects is attributable to the individuals whose rights are unjustifiably infringed, and they have suffered from violation of their rights, i.e., from the offenses, including crimes. The Constitutional rights stated in

Latvijas Republikas Satversmes komentāri. VIII nodaļa. Cilvēka pamattiesības. Autoru kolektīvs prof. R. Baloža zinātniskā vadībā. Rīga, Latvijas Vēstnesis, 2011, p. 123.

2 Konstitucionālais likums “Cilvēka un pilsoṇa tiesības un pienākumi”. Latvijas Republikas Augstākās padomes un Valdības Ziņotājs, 1992. 30. janvāris, Nr. 4.

3 Konstitucionālo tiesību komisijas 2012. gada 17. septembra viedoklis par Latvijas valsts konstitucionālajiem pamatiem un neaizskaramo Satversmes kodolu. Available at http://www. president.lv/images/modules/items/PDF/17092012_Viedoklis_2.pdf [last viewed June 11, 2016].

4 Grozijumi Latvijas Republikas Satversmē: LR likums. Latvijas Vēstnesis, 1998. 23. oktobris, Nr. 308/312 (1369/1373). 
the Article 92 of the Constitution are included also in the Article 22 of the Criminal Procedure Law, ${ }^{5}$ indicating that a person, upon whom harm has been inflicted by a criminal offence shall, taking into account the moral injury, physical suffering, and financial loss thereof, be guaranteed procedural opportunities for the requesting and receipt of moral and financial compensation. Provision of compensations for the victims of crime is envisaged also in the European Convention, November 24, 1983, on the awarding compensation to victims of crimes ${ }^{6}$ and in its explanatory report. ${ }^{7}$ The Artice 13 of the European Covention of Human Rights also states that "Everyone, whose rights and freedom as stated in the current Convention have been infringed,has the right to effective protection from the state institutions, despite the fact, that the offense has been committed by the individual while performing their public duties". Besides, the Directive No. 2004/80EK, ${ }^{9}$ April 20, 2004 also envisages compensations to the victims of crimes. ${ }^{10}$

On October 25, 2012, the European Parliament and the EU Council adopted the Directive No. 2012/29EU, ${ }^{11}$ by which the rights of the victims of crime, support and minimum standards were adopted. The adoption of the Directive dealt with the necessity to preserve and develop the European common legal space, to promote an individual's safety and freedom. The Directive supplemented the Framework Decision No. 2001/220/TI. ${ }^{12}$ The aim of the adoption of the Directive addressed the necessity to improve the protection of the victims of crime, their support and participation in the criminal proceedings. The acceptance of the Directive favoured the adoption of amendments in the national legal documents, providing, that the victims in the whole European Union can rely on a unified minimum guaranteed level, regardless of what EU member state the crime has been committed. Legal regulation, dealing with the protection of rights of the victims of crime more directly

Kriminālprocesa likums: LR likums: Latvijas Vēstnesis Nr. 74 (3232), 11.05.2005.

6 European Convention on the Compensation of Victims of Violent Crimes. Available at http:// conventions.coe.int/Treaty/en/Treaties/Html/116.htm [last viewed June 11, 2016].

7 Explanatory Report of European Convention on the Compensation of Victims of Violent Crimes. Available at http://conventions.coe.int/Treaty/EN/Reports/Html/116.htm [last viewed May 14, 2016].

8 The European Convention on Human Rights. Available at http://www.echr.coe.int/pages/home.as px?p=basictexts\#n1359128122487_pointer [last viewed June 11, 2016].

9 Council Directive 2004/80/EC of 29 April 2004 relating to compensation to crime victims. Available at http://eur-lex.europa.eu/LexUriServ/LexUriServ.do?uri=OJ:L:2004:261:0015:0018: en:PDF [last viewed June 11, 2016].

10 Non-criminalremedies for crime victims. Directorate General of Human Rights and Legal Affairs, Council of Europe, 2009 pp. 43-48. Available at http://www.coe.int/t/dghl/standardsetting/ victims/victims\%20final_en\%20with\%20cover.pdf [last viewed June 11,2016].

11 Directive 2012/29/EU of the European Parlament and of the Council of 25 October 2012 establishing minimum standards on the rights, support and protection of victims of crime, and replacing Council Framework Decision No. 2001/220/JHA. Available at http://eur-lex.europa. eu/legal-content/EN/TXT/HTML/?uri=CELEX:32012L0029\&from=LV [last viewed June 11, 2016].

12 Council Framework Decision of 15 March 2001 on the standingof victims in criminal proceedings No. 2001/220/JHA. Available at http://eur-lex.europa.eu/LexUriServ/LexUriServ.do?uri=OJ:L: 2001:082:0001:0004:en:PDF [last viewed June 11, 2016]. 
determines not only the compensation of the damage, but also the duty of the country to provide protection of the victims and the compensation of the inflicted violation of the law.

It is important to state that professor $\bar{A}$. Meikališa analyzed the aforementioned EU Directive on minimum standards of the victims' rights and the possible effect on the criminal process in Latvia already in 2013 in the Scientific Conference of the University of Latvia. ${ }^{13}$ The author noted that, by implementing the requirements of the Directive, it would be necessary to perfect the measures of criminal proceedings, making amendments in the respective legal acts, as well as realizing support and protection activities of victims in non-criminal proceedings. ${ }^{14}$

One of the most essential and fundamental questions is related to the understanding of the concept "victim". The Article 2 of the Directive defines the victim, as follows:

a) a natural person who has suffered harm, including physical, mental or emotional harm or economic loss which was directly caused by a criminal offence;

b) family members of a person whose death was directly caused by a criminal offence and who have suffered harm as a result of that person's death; "family members" means the spouse, the person who is living with the victim in a committed intimate relationship, in a joint household and on a stable and continuous basis, the relatives in direct line, the siblings and the dependants of the victim.

In correspondence with the Section 95 of the Criminal Procedure Law, a victim in criminal proceedings may be a natural person or legal person to whom harm was caused by a criminal offence, that is, a moral injury, physical suffering, or a material loss.

If a person has passed away, the victims in the criminal proceedings can be particular relatives of the deceased. The Chapter 2 of the abovementioned Section states that a victim in criminal proceedings may not be a person to whom moral injury was caused as a representative of a specific group or part of society. The comparative analysis of the definition of the victim in the Directive and in the Law of Criminal Proceedings describes a certain conflict as to the content of the concept. Firstly, the Criminal Procedure Law quite groundedly declares that legal entities can be victims as well. For example, the criminal proceedings undertaken in Zolitude tragedy in Latvia,"where one legal entity ("Maxima Latvija”, Ltd.) is announced as the victim in one criminal offense (CL Article 239 - violation of construction rules)" ${ }^{15}$ Within the Civil Law, one cannot find a direct definition of the concept "a thing belonging to somebody." E. Kalniņš, by the concept of "a thing belonging

13 Meikališa A. Jaunas vēsmas cietušo aizsardzībā - ES direktīva par cietušo tiesību minimālajiem standartiem un tās iespējamā ietekme uz kriminālprocesu Latvijā. Tiesību interpretācija un tiesību jaunrade - kā rast pareizo līdzsvaru: Latvijas Universitātes 71. zinātniskās konferences rakstu krājums. Rīga: LU Akadēmiskais apgāds, 2013, 140.-146. lpp.

14 Ibid., p. 142.

15 Bordāns T. Juridiskā persona uz apsūdzēto sola jeb atsevišķas piezīmes par “Maximas” krimināllietu. Jurista Vārds, 2016, 12. janvāris, Nr. 2 (905). 
to somebody" in its direct sense understands a set of all subjective rights estimated in cash, belonging to a certain rightholder, "....among other things, there is defined also the property in its material sense (like active and passive wholeness of one's belongings) and even separate bodily parts". ${ }^{16}$

According to the Law "On the Procedures for the Coming into Force and Application of the Criminal Law", Section 23, parts 1 and 2, "Liability for the criminal offence provided for in the Criminal Law, by which substantial harm has been caused, shall apply, if as the result of the criminal offence not only significant financial loss has been caused, but also other interests protected by law were threatened, or if such threat was significant. (2) Financial loss, which at the time of committing the crime exceeds five times the minimum monthly wage as determined at the time in the Republic of Latvia, shall be deemed to be significant financial loss." ${ }^{17}$

Secondly, the harm to the victims of crime as formulated in the Directive could be interpreted much broader. Thus, the emotional harm included in the Directive, which could be attributed to the psychic process of the victim, the unfavourable changes of qualities and conditions. Recognizing the victim's rights in respect to adequate compensation, it would be necessary to define the harm caused to the definite person, taking into account the person's moral harm, physical sufferings and material losses. The harm caused is based on firm evidence, as well the victim's subjective evaluation. Subjective evaluation of the damage, in fact, cannot be practically checked, because no objective criteria have been developed to appraise moral harm, emotional experience, evaluation of psychic sufferings. However, relevant criteria and guidelines for their identification would be necessary. Only on the basis of sufficiently objective assessment of the amount of moral harm and mental sufferings one can determine an adequate compensation.

In line with constitutional values, the Directive envisages that the victims of crime should be recognized and be treated with dignity, sympathetically and professionally, and without any discrimination, based on such considerations as race, skin colour, ethnic or social origin, genetic peculiarities, language, religion or belief, political or any other views, belonging to a certain national minority. The Directive, by the way, precludes unequal attitude based on such manifestations as property, origin, disability, age, sex, gender identity, gender orientation, residence status or health (Article 9).

The Directive states that the support to victims of crime should be available from the moment when the competent authorities have learned about the victim, during the period of whole criminal proceedings, and also a corresponding period after these proceedings in line with the victim's needs and the rights as stated in this Directive. Support should be rendered in different ways without any excessive

16 Kalniņš E. Mantas jēdziens civiltiesībās. Latvijas Universitātes Žurnāls “Juridiskā zinātne”, 2010, Nr. 1, 150. lpp.

17 Likums "Par Krimināllikuma spēkā stāšanās un piemērošanas kārtïbu". Available at http://likumi.lv/doc.php?id=50539http://likumi.lv/doc.php?id=50539 [last viewed June 29, 2016]. 
formalities, ensuring sufficient geographic distribution in the member states, in order all the victims could have an access to such services.

According to the Articles 8 and 9 of the Directive, it was important in Latvia to introduce the victims' hotline free of charge (informative, supportive), which would help the victims of crime learn the possibilities to get available support, take further action and activities to perform, as well as the rights to be listened to. Victims' hotline is a coordinating contact point, where one can find the necessary information in a simple way, free of charge. Since January 1, 2016, in Latvia a free of charge hotline for victims of crime has begun to function - the telephone no. 116006, where consultations and necessary support are rendered by the staff of Crisis and Consultation Centre "Skalbes". ${ }^{18}$ At the same time, there is still no unified support service in Latvia. The costs for the development of such a service are said not to be reasonable, comparing to the benefit to the society. The study on victims' satisfaction with the support services has also repeatedly proved that the lack of information is the main cause of dissatisfaction with regard to criminal proceedings, as well as the fact that victims are forbidden to participate in them. ${ }^{19}$

The Directive of victims lists the compulsory items required to make a contribution into equipment of the staff and provision with extra premises. For instance, it includes provision of the waiting room for the victim in court separately from the waiting rooms of the accused. State institutions have to provide the technologies for video communication and video recording, for mandatory training of the staff, for example, police officers and court staff. Besides, it is important to develop methodology and ensure individual assessment of victims to specify their individual safety needs.

In accordance with the Article 19 of the Directive, an individual can be considered a victim regardless of whether a person who has committed crime is identified, arrested, accused or convicted, and apart from the familial relationships between them. Respectively, a person is identified as the victim of crime from the moment when the criminal proceedings have been initiated and the material or also non-material damage defined. Victims of crime or their relatives may have also experienced harm of moral character, moral pain and sufferings. It is important to say, that the Constitutional Court in its verdict of 2011 has admitted ${ }^{20}$ that in the concept "adequate compensation" it is very essential to consider the scope of fundamental rights and in the cases where there is unfounded violation of rights, everyone is entitled to an adequate compensation. In its application to the Constitutional Court, the Department of Civil Matters of the Supreme Court mentions the fact that the goal of adequate compensation is to achieve the effective restoration of justice, which is an effective means of legal protection. ${ }^{21}$

18 Informēs par atbalsta iespējām noziegumu upuriem. Available at http://www.skalbes.lv/noderigi/ informes-par-atbalsta-iespejam-nozieguma-upuriem/1118 [last viewed June 11, 2016].

19 Sims L., Myhill A. Policing and the Public: Findings from the 2000 British Crime Survey. Home Office Research Findings 136, London: Home Office, 2001.

20 Satversmes tiesas 2012. gada 6. jūnija spriedums lietā Nr. 2011-21-01, 6. punkts.

21 Augstākās tiesas Civillietu departamenta 2014. gada 28. februāra lēmums lietā Nr. SKC-46/2014, 8.4. punkts. 
The range of people entitled to be considered victims is expanded and the respective status is attributable to the victim's relative, if, as a result of crime, the harm has been caused also to the family members of the victim. Classififcation is provided, for example, especially severe damage, resulting in a person's death caused by the crime. Legal protection and help are attributable also to the family members whose relative had been killed. Therefore, family members, who have been indirect victims, should be entitled to protection as defined in the directive. The Member States should still be able to introduce procedures to limit the respective number of family members, who can apply the rights stated in this directive. If the victim is a child, this child or a person who has parental responsibility, if only it is not against the child's interests, should be entitled, in the name of the child, to use the rights as stated in the Directive. Article 32 of the Directive states that victims, at their request, should receive precise information on the offenders release or escape.

On February 18, 2016, the Saeima adopted amendments in the Sentence Execution Code of Latvia to supplement it with Article 112,22 to send information to the victim. This Article states that the administration of penitentiary institutions must send information to the victim on the release of the sentenced or his/her escape from prison, if an information from the facilitator of the proceedings has been received, stipulating the necessity to inform thereof. Amendments in the Sentence Execution Code of Latvia also state: if the sentenced is released after the sentence has been served, the information is sent to the victim not later than 15 working days prior to the anticipated release from the prison.

If the relase of the sentenced from the prison is based on different grounds, or if he/she has escaped from this institution, the information to the victim is sent immediately after the respective documents have been received on the release of the sentenced, or the information about his/her escape. The information available in the announcement of information is of a limited availability.

In some publications, it is indicated that not all victims have a right to demand information on the sentenced persons. ${ }^{23}$ Corresponding rights are given only to especially protected persons. Amendments to the Criminal Procedure Law in force sinceNovember 16, 2015 define that victims that can receive special procedural protection are: 1) the underaged; 2) persons who, due to mental condition or other health problems cannot use their procedural rights; 3) persons who have suffered from crime, directed at the person's virtue or sexual privacy, or from human trafficking; 4) persons who have suffered from crime related to violence or threat of violence committed by a person of the first or second degree of kinship, a spouse or a former spouse, a person with whom the victim has lived in registered marriage, or persons, with whom the victims have shared household; 5) persons, who, as a result of crime, may suffer from severe bodily injuries or mental disorders; 6) persons who

22 Grozijumi Latvijas Sodu izpildes kodeksā. Available at http://likumi.lv/doc.php?id=280783http:// likumi.lv/doc.php?id=280783 [last viewed May 12, 2016].

23 Gabre A. Neviens cietušais vēl nav brīdināts. Neatkarīgā Rīta Avīze, Nr. 107 (7245), 3.-5. jūnijs, 2016. 
have suffered from crime, which may have been committed due to racial, national, ethnic or religious motives.

It is noted that giving information to the victim on the release of the sentenced from the prison depends on the severity of crime, or, if there exists the risk of repeated threat. The legislator has not stated, that the victim cannot be informed about the person's release who has committed a less severe crime. It is possible that there has existed a long-term hostile relationship between the victim and the person sentenced, resulting in committing moderately severe bodily injury to the victim, and temporary imprisonment of the offender. There are great doubts that the officials of the prison could have grounded information on the fact that the victim may have the risk of a repeated threat.

The aspect related to the possibility of getting information at the request of the victim may be disputable. Corresponding procedural norm should be included into the Law of Criminal Proceedings and Penal Procedure Law. The authorities of Penal Procedure or courts not always will have the possibility to establish that the victim may be endangered, or when the risk of harm to the victim is identified. The term "identified risk of harm to victims" is attributed to such aspects as the character of crime and its severity, the revenge risk or their possibility. At the same time, the character of crime and its severity is not determined for "victims suffering from the risk of harm". In the Directive, however, it is said, that the information to the victim would not be attributed in case of trifle crimes and, therefore, there is a little opportunity that the victim may be subject to suffering from harm. It should, likewise, be considered if the offender may not suffer the risk of harm, which may result from the information. If it is clear that the announcement of information can cause the risk of harm to the offender, the competent institution, by taking adequate steps, should consider all other possible risks.

\section{Conclusion}

In conclusion, it is important to note that the range of persons recognized as victims in the international and national regulations is increasing. In the respective legal acts, the guidelines are identified for the determination of the appropriate renumeration, compensation and the scope of supportive measures and specification of procedures for their implementation. And still, protection of constitutional rights of victims of crime in practice has to be perfected and developed. In protection of victims, special measures are needed for ensuring the protection of the minors' rights, as well as protection of victims of criminal offenses. It is important not only to take supportive action, but also to provide compensation for a specific damage. In order for the victims to receive sufficient support, help and protection, the public services should coordinate their work, and become involved at all administrative levels at the European Union level, and at the national, regional and local levels. For protection of victims at the international level, it is important to exchange the positive experience regarding support of victims, to cooperate within the European legal framework on the issues directly targeted at the victims' rights. 


\section{BIBLIOGRAPHY}

\section{Literature}

1. Latvijas Republikas Satversmes komentāri. VIII nodaļa. Cilvēka pamattiesības. Autoru kolektīvs prof. R. Baloža zinātniskā vadỉbā. Rìga, Latvijas Vēstnesis, 2011, 123 lpp.

2. Meikališa A. Jaunas vēsmas cietušo aizsardzībā - ES direktīva par cietušo tiesību minimālajiem standartiem un tās iespējamā ietekme uz kriminālprocesu Latvijā. Tiesību interpretācija un tiesību jaunrade - kā rast pareizo līdzsvaru: Latvijas Universitātes 71. zinātniskās konferences rakstu krājums. Rīga: LU Akadēmiskais apgāds, 2013, 140.-146. lpp.

3. Sims L., Myhill A. Policing and the Public: Findings from the 2000 British Crime Survey. Home Office Research Findings 136, London: Home Office, 2001.

\section{Legislative acts}

1. Council Directive 2004/80/EC of 29 April 2004 relating to compensation to crime victims. Available at http://eur-lex.europa.eu/LexUriServ/LexUriServ.do?uri=OJ:L:2004:261:0015:0 018:en:PDF [last viewed June 11, 2016].

2. CouncilFrameworkDecision of 15 March 2001 on the standingof victims in criminal proceedings No. 2001/220/JHA. Available at http://eur-lex.europa.eu/LexUriServ/LexUriServ.do?uri= OJ:L:2001:082:0001:0004:en:PDF [last viewed June 11, 2016].

3. Directive 2012/29/EU of the European Parliament and of the Council of 25 October 2012, establishing minimum standards on the rights, support and protection of victims of crime, and replacing Council Framework Decision No. 2001/220/JHA. Available at http://eur-lex.europa.eu/legal-content/EN/TXT/HTML/?uri=CELEX:32012L0029\& from $=\mathrm{LV}$ [last viewed June 11, 2016].

4. European Convention on the Compensation of Victims of Violent Crimes. Available at http://conventions.coe.int/Treaty/en/Treaties/Html/116.htm [last viewed June 11, 2016].

5. Explanatory Report of European Convention on the Compensation of Victims of Violent Crimes. Available at http://conventions.coe.int/Treaty/EN/Reports/Html/116.htm [last viewed June 11, 2016].

6. Grozijumi Latvijas Republikas Satversmē: LR likums. Latvijas Vēstnesis, 1998. 23. oktobris, Nr. 308/312 (1369/1373).

7. Grozījumi Latvijas Sodu izpildes kodeksā. Available at http://likumi.lv/doc.php?id=28078 [last viewed June 11, 2016].

8. Konstitucionālais likums "Cilvēka un pilsoṇa tiesības un pienākumi”. Latvijas Republikas Augstākās Padomes un Valdības Ziņotājs, 1992. 30. janvāris, Nr. 4.

9. Likums "Par Krimināllikuma spēkā stāšanās un piemērošanas kārtību”. Available at http:// likumi.lv/doc.php?id=50539 [last viewed June 11, 2016].

10. Non-criminalremedies for crime victims. Directorate General of Human Rights and Legal Affairs, Council of Europe, 2009, pp. 43-48. Available at http://www.coe.int/t/dghl/ standardsetting/victims/victims\%20final_en\%20with\%20cover.pdf [last viewed June 11, 2016].

11. The European Convention on Human Rights. Available at http://www.echr.coe.int/pages/ home.aspx?p=basictexts\#n1359128122487_pointer [last viewed June 11, 2016]. 


\section{Legal practice}

1. Augstākās tiesas Civillietu departamenta 2104. gada 28. februāra lēmums lietā Nr. SKC46/2014, 8.4. punkts.

2. Konstitucionālo tiesību komisijas 2012. gada 17. septembra viedoklis par Latvijas valsts konstitucionālajiem pamatiem un neaizskaramo Satversmes kodolu. Available at http//www. president.lv/images/modules/items/PDF/17092012_Viedoklis_2.pdf [last viewed June 11, 2016].

3. Satversmes tiesas 2012. gada 6. jūnija spriedums lietā Nr. 2011-21-01, 6. punkts.

\section{Ohter sources}

1. Bordāns T. Juridiskā persona uz apsūdzēto sola jeb atsevišķas piezīmes par "Maximas" krimināllietu. Jurista Vārds, 2016, 12. janvāris, Nr. 2 (905).

2. Gabre A. Neviens cietušais vēl nav brīdināts. Neatkarīgā Rīta Avīze, Nr. 107 (7245), 3.-5. jūnijs, 2016.

3. Informēs par atbalsta iespējām noziegumu upuriem. Available at http://www.skalbes.lv/ noderigi/informes-par-atbalsta-iespejam-nozieguma-upuriem/1118 [last viewed June 11, 2016].

4. Kalniņ̧̌ E. Mantas jēdziens civiltiesībās. Latvijas Universitātes žurnāls "Juridiskā zinātne”, 2010, Nr. 1, 150. lpp. 
Julija Kolomijceva, $M g$. iur.

University of Latvia, Latvia

\title{
PROTECTION OF THE RIGHT TO PROPERTY OF BONA FIDE PERSONS WITHIN CRIMINAL PROCEEDINGS
}

\begin{abstract}
Summary
This article is about the protection of the constitutional right to property of bona fide persons and its possible infringement on the rights of bona fide persons, while applying compulsory measures of substantial or procedural criminal law, in the course of criminal proceedings.
\end{abstract}

Keywords: the right to property, bona fide, good faith, criminally acquired property.

\section{Bona fide in Private Law}

Bona fide is mainly of importance in Private Law. Bona fide is lack of knowledge of facts that do not allow acquiring the Ownership Right or Pledge Right (Article 910, 1343 and 1065 of the Civil Law ${ }^{1}$ ).

The concept of bona fide acquisition is narrower in comparison with "good faith". Article 1 of the Civil Law states, one shall assert his rights and perform his duties in good faith. Good faith is the requirement to act fairly, honestly and loyally; and, to consider the reasonable interests of other persons. ${ }^{2}$ Nevertheless, the "good faith" principle can be used to specify the required standard of conduct for the bona fide acquirer. The bona fide acquirer must act as bonus pater familias; i.e., a person who does not solely pursue his own goals, but also takes into consideration the (possible infringed) interests of others. ${ }^{3}$ The bona fide acquirer is a reasonable person who carefully balances the pros and cons before engaging in any activity, whether legal or illegal. ${ }^{4}$

Civillikums: LR likums. Available at http://likumi.lv/doc.php?id=225418 [last viewed November 1, 2016].

2 Balodis K. Ievads civiltiesībās. Rīga: Zvaigzne ABC, 2007, 142.-144. lpp.; Latvijas Republikas Augstākās Senāta Civillietu departamenta 2013. gada 10. oktobra spriedums lietā Nr. SKC-166/2013.

3 European Group on Tort Law. Principles of European Tort Law: Text and Commentary. Wien: Springer, 2005, p. 76.

4 Stessens G. Money Laundering: A New International Law Enforcement Model. Cambridge: Cambridge University Press, 2003, p. 52. 
The bona fide acquirer is positively confident that there are no legal obstacles in acquiring a real (in rem) right. ${ }^{5}$ His confidence is supported by objective circumstances, or facts, associated with acquisition. ${ }^{6}$

In contrast to the bona fide acquirer, a person is in mala fide, if he acted intentionally, or could possibly have known of obstacles because of his gross or slight negligence. In other words, even slight deviations from the standard of bonus pater familias exclude bona fide. ${ }^{7}$

If in a concrete situation, and under concrete circumstances, reasonable doubt about the existence of obstacles to acquire in rem rights existed, but a person failed to gather additional information, he is not bona fide (Article 1013 of the Civil Law). Although intent or negligence exclude bona fide in Private Law, these terms shall not be confused with the same, identical terms of Criminal Law. In Private Law, intent and negligence are adapted to an objective standard (i.e. bonus pater familias). However, in Criminal Law, they allude to the individual (subjective) personality of the liable person. ${ }^{8}$ A person, who is not liable for a crime, may be a bona or mala fide party at the same time. Simultaneously, a person is not a bona fide party, if he committed a crime and illegally gained property.

\section{The right to property and its scope}

Article 105 of the Constitution of the Republic of Latvia (Latvijas Republikas Satversme ${ }^{9}$ ) stipulates that everyone has the right to own property. The fundamental right to property encompasses all subjective rights of a material nature, which a person can use on his own behalf; and which he can deal with according to his will. Such rights include, for example, the Right of Ownership (Article 927 of the Civil Law), various other real rights, obligatory claims arising on the basis of various legal grounds, rights attached to shares of company stock, intellectual property rights, etc. Various economic interests, which are not subjective rights, for example,

5 Civillikumi ar paskaidrojumiem. Otrā grāmata. Lietu tiesības. Sast. F. Konradi, A. Walter. Likuma teksts prof. Dr. iur. A. Būmaņa, H. Ėlersa un J. Lauvas tulkojumā. Rìga: Grāmatrūpnieks, 1935, 58. lpp.

6 Latvijas Republikas Augstākās tiesas Senāta Civillietu departamenta 2008. gada 2. aprīla spriedums lietā Nr. SKC-143; Ventspils tiesas 2015. gada 4. jūnija spriedums lietã C33211215; Blaese H., Mende S. Lettlands Zivilgesetzgesetzbuch in Einzeldarstellungen vom 28. Januar 1937. Band II, 2. Das Sachenrecht. Riga: Verlag der AG "ErnstPlates", 1940, S. 116-117.

7 Leja L. Par labticigā ieguvēja aizsardzību, prettiesiski atsavinot līzinga objektu (I). Available at http://www.juristavards.lv/doc/84089-par-labticiga-ieguveja-aizsardzibu-prettiesiski-atsavinotlizinga-objektu/ / [last viewed November 1, 2016]; Balodis K. Sicherungsübereignung im deutschlettischen Rechtsvergleich. Riga: Latvijas Universitāte, 2001, S. 235; Lutzau H. von. Studien un Kritiken zum Ostseeprovinziellen Privatrecht. Erster Band. Riga: Verlang von Jonck und Poliewsky, 1908, S. 213.

8 Krastinšs U., Liholaja V., Niedre A. Krimināltiesības. Vispārīgā daḷa. Trešais papildinātais izdevums. Zinātniskais redaktors prof. U. Krastinšs. Rīga: Tiesu namu aǵentūra, 2008, 151. lpp.; Torgāns K. Saistību tiesības. I dal̦a. Rīga: Tiesu namu ağentūra, 2006, 198. lpp.

9 Latvijas Republikas Satversme: LR likums. Available at http://www.saeima.lv/en/legislation/ constitution [last viewed November 1, 2016]. 
goodwill, also fall within the concept of the Constitutional Right to Property. This right to property is protected, when property has already been acquired, or when there exists a well-founded claim, which may be satisfied in future. ${ }^{10}$

The notion of the right to property complies with the concept of 'possessions', from Protocol No. 1 of the European Convention on Human Rights; which, inter alia, Article 89 of the Constitution of Latvia ensues. ${ }^{11}$ The term 'possessions' is not limited to ownership of physical goods. Various other rights and interests, constituting assets, can also be considered property rights, and thus be viewed as 'possessions. ${ }^{12}$ The notion then, applies to a person's existing possessions, ${ }^{13}$ or assets, including claims, in respect of which a person can argue that he has at least a "legitimate expectation" that they will be realised. ${ }^{14}$

The notion of bona fide is connected to acquisition of ownership, or pledge in Private Law. However, the state must ensure adequate protection of the right to property of creditors, who were in good faith, of an offender; i.e., these creditors were oblivious to, and could not have known about the crime committed by the offender. The standard of bonus pater familias can be used, in this case, as well. As a result, the notions of bona fide acquirer and 'person who acted in good faith', will be used synonymously in the article unless otherwise specified.

The right to property may be restricted only in accordance with law (Article 105 of the Constitution). Property may not be used contrary to the interests of the public. Furthermore, the law must have a legitimate aim. The law restricting the right to property must also comply with the principle of proportionality. The principle of proportionality is infringed when: 1) the law is not suitable for achieving the pursued, legitimate, aim; 2) the legitimate aim may be reached by alternative means, which will lesser restrict the rights and legal interests of an individual; 3) the benefit of the society will not be greater than the loss incurred to the rights and lawful interests of an individual. If the law does not comply with even one of the three criteria, then it does not conform to the principle of proportionality. ${ }^{15}$

10 Latvijas Republikas Satversmes tiesas 2012. gada 7. jūnija spriedums lietā Nr. 2011-19-01. Available at http://likumi.lv/doc.php?id=248964 [last viewed November 1, 2016].

11 Latvijas Republikas Satversmes tiesas 2005. gada 13. maija spriedums lietā Nr. 2004-18-0106. Available at http://www.satv.tiesa.gov.lv/wp-content/uploads/2016/02/2004-18-0106 Spriedums.pdf [last viewed February 18, 2016]; Latvijas Republikas Satversmes tiesas 2005. gada 14. septembra spriedums lietā Nr. 2005-02-0106. Available at http://likumi.lv/doc.php?id=116761 [last viewed February 18, 2016]; Latvijas Republikas Satversmes tiesas 2006. gada 23. novembra spriedums lietā Nr. 2006-03-0106. Available at http://likumi.lv/ta/id/148871 [last viewed February 18, 2016].

12 Judgment of European Court of Human Rights, Case No. 15375/89 Gasus Dosier- und Fördertechnik GmbH v. the Netherlands

13 Judgment of European Court of Human Rights, Case No. 6833/74 Marckx v. Belgium.

14 Decision of Grand Chamber of European Court of Human Rights, Case No. 39794/98 Gratzinger and Gratzingerova v. the Czech Republic.

15 Latvijas Republikas Satversmes tiesas 2003. gada 20. maija spriedums lietā Nr. 2002-21-01. Available at http://likumi.lv/doc.php?id=75081 [last viewed February 18, 2016]. 
Expropriation of property for public purposes is allowed only in exceptional cases on the basis of a specific law and in return for fair compensation (Article 105 of the Constitution).

The Constitutional Court holds that the right to property does not apply to criminally obtained property. ${ }^{16}$ Only the state, therefore, acting in the general interest of the state, may confiscate, i.e., acquire, criminally gotten property, ${ }^{17}$ if this property is not returnable to an identified victim. In particular, criminally obtained property may not be distributed among creditors in insolvency proceedings, but shall be confiscated. ${ }^{18}$

The above opinion can be partly joined, if the confiscation refers to criminally gained assets of perpetrators or mala fide third persons.

The state may, undoubtedly, deprive offenders of property, which was directly or indirectly acquired via a criminal offence (Article 240 and 358, Paragraph 1 of the Criminal Procedure Law (Kriminālprocesa likums ${ }^{19}$ )). Deprivation of unlawfully obtained property, which is owned by perpetrators, will therefore not be regarded as an interference or expropriation of the right to property, under Article 105 of the Constitution.

Even though protection of the right to illegally gained property does not extend to persons guilty of a crime, it does extend to an innocent owner, acting in good faith, who must be able to recover his property. ${ }^{20}$ Bona fide persons, who believe that their rights to property have been violated, shall have effective and practical remedies to prevent further or continued violation; and also shall be provided with means of adequate redress for any concurrent violation. ${ }^{21}$

16 Latvijas Republikas Satversmes tiesas 2009. gada 28. maija spriedums lietā Nr. 2008-47-01. Available at http://www.satv.tiesa.gov.lv/wp-content/uploads/2016/02/2008-47-01_Spriedums. pdf [last viewed November 1, 2016]. Latvijas Republikas Satversmes tiesas 2010. gada $\overline{7}$. decembra lēmuma par tiesvedības izbeigšanu lietā Nr. 2010-31-01. Available at http://likumi.lv/doc. php?id=224057 [last viewed November 1, 2016].

17 Rìgas rajona tiesas 2010. gada 15. jūnija lēmums lietā Nr. 11816000309; Rìgas pilsētas Centra rajona tiesas 2010. gada 29. decembra lēmums lietā Nr. K-27-493/10/4; Rigas pilsētas Latgales priekšpilsētas tiesas 2011. gada 27. jūnija lēmums lietā Nr. 11816002809/K29-1122/11; Rìgas apgabaltiesas Civillietu tiesu kolēǵijas 2015. gada 25. novembra lēmums lietā Nr. C30306315.

18 Latvijas Republikas Augstākās tiesas Senāta Krimināllietu departamenta 2008. gada 28. augusta lēmums lietā Nr. SKK-473/08.

19 Kriminālprocesa likums: LR likums. Available at http://likumi.lv/doc.php?id=107820\#p626\&pd=1 [last viewed November 1, 2016].

20 Dissenting opinion of Judge Pettiti, Judgment of European Court of Human Rights, Case No. 9118/80 Agosi v. the United Kingdom; Dissenting opinion of Judge Martens, joined by Judge Russo, Judgment of European Court of Human Rights, Case No. 18465/91 Air Canada v. the United Kingdom.

21 Decision of Grand Chamber of European Court of Human Rights, Case No. 30210/96 Kudla v. Poland. 
To compare, the vast majority of EU national confiscation systems can be applied to mala fide third parties, but the rights acquired on assets representing the proceeds of a crime by bona fide third parties are respected. ${ }^{22}$

A victim can be either in good or bad faith. The victim has acted in bad faith if he knew or should have known of the criminal aims of the transferee (Article 2387 of Civil Law). This approach corresponds to Article 105 of the Constitution, in that property shall not be used contrary to the interests of the public.

\section{Protection of bona fide persons within criminal proceedings}

Article 12, Paragraph 1 of the Criminal Procedure Law explicitly states that fundamental rights must be observed in criminal proceedings. Still, protection of the right to property of bona fide persons, including victims, is not always effective in law and practise.

If civil claims of bona fide persons have not been settled before, or together with the decision on imposing of criminal penalties, or other compulsory sanctions of economic nature, an offender can become insolvent; consequently, he will not be able to satisfy civil claims of bona fide persons at the later stage of a criminal proceeding, or in subsequent civil proceedings. For example, a bona fide person will actually receive no compensation if, earlier, the state confiscated the entire property of a perpetrator, or most of it, and the confiscation was a punishment for a crime or it was directed against means to commit the offence. ${ }^{23}$ The same problem can also arise, if the issue of confiscation of illicit property has been adjudicated separately from the rest of a criminal case, in pre-trial criminal proceedings, for example, but the claims of victims have not been settled at that moment. ${ }^{24}$

One of the possible solutions would be to pass a rule that criminal penalties and other sanctions with an economic effect set by the Criminal Law (Kriminällikums), ${ }^{25}$ or Criminal Procedure Law, are not executed, if claims of bona fide persons have not been satisfied or security has not been provided.

It can be also considered whether bona fide persons could directly receive adequate, monetary compensation from the public treasury, if their property rights have been violated.

However, assets of offenders are frequently transferred among family members, as a means of escaping confiscation or execution of other penalties of an economic

22 Vettori B. Tough on Criminal Wealth: Exploring the Practice of Proceeds from Crime Confiscation in the EU. Dordrecht: Springer, 2006, p. 8.

23 Latvijas Republikas Augstākās tiesas Senāta Krimināllietu departamenta 2013. gada 23. maija lēmums lietā Nr. SKK-306/2013.

24 Rīgas apgabaltiesas Krimināllietu tiesu kolēǵijas 2011. gada 1. novembra lēmums lietā Nr. 11816002109

25 Krimināllikums: LR likums. Available at http://likumi.lv/doc.php?id=88966 [last viewed November 1, 2016]. 
nature. ${ }^{26}$ In order to create a fair balance between public interests and the interests of bona fide persons, who may have paid consideration or subsequently arranged their affairs in reliance on their changed financial situation, rebuttable assumptions can be introduced. ${ }^{27}$ Such assumptions are commonplace in the field of Insolvency Law, where it is important to have rules in place for voiding transactions carried out to avoid liability. For example, Finnish Confiscation Law refers directly to Insolvency Law in defining the relevant categories of "close persons". 28

The Latvian Criminal Procedure Law contains slightly similar presumptions, albeit only in cases of the extended confiscation of criminally acquired property. Accordingly, close persons of a criminal - persons living in the criminal's household or persons who are controlled by the criminal - must prove that their assets are legally obtained (Article 355, Paragraph 2 and 3 of the Criminal Procedure Law). It seems that the rule tries to combine the concepts of close persons to the offender and beneficial owner.

In comparison, Article 72 of the Insolvency Law (Maksātnespējas likums ${ }^{29}$ ) states that close persons (ieinteresētās personas) of the insolvent person are: 1) his spouse, as well as his or his spouse's children, grandchildren, parents, grandparents and siblings; 2) a legal person or a company without legal personality of which the insolvent person or one of his relatives mentioned before is a founder, shareholder or member of the body representing or supervising this legal person or company; 3 ) a person vested with (general) commercial power of representation of the insolvent person; 4) a creditor who is a part of the one and same concern together with the insolvent person.

Transactions concluded with close persons of the insolvent debtor can be contested, since it is presumed that a close person was mala fide, unless they can prove otherwise (Article 96 of the Insolvency Law).

The notion of beneficial owner is introduced in the Law on the Prevention of Money Laundering and Terrorism Financing (Noziedzigi iegūtu lìdzekḷ legalizācijas un terorisma finansēšanas novēršanas likums ${ }^{30}$ ). The term 'beneficial owner' refers to a natural person who ultimately owns or controls a legal person, or a natural person on whose behalf a transaction or activity is being conducted (Article 1 of the Law on the Prevention of Money Laundering and Terrorism Financing).

26 Barkāns E. Dāvinājuma ligumi - fiktivvi darījumi? Available at http://www.delfi.lv/news/ comment/comment/elmars-barkans-davinajuma-ligumi-fiktivi-darijumi.d?id=13741585 [last viewed November 1, 2016].

27 Forsaith J., Irving B., Nanopoulos E., Fazekas M. Technical report. Study for an impact assessment on a proposal for a new legal framework on the confiscation and recovery of criminal assets. Prepared for the European Commission Directorate General Home Affairs. RAND Europe, 2012, p. 205

28 Ibid.

29 Maksātnespējas likums: LR likums. Available at http://likumi.lv/doc.php?id=214590 [last viewed November 1, 2016].

30 Noziedzīgi iegūtu līdzekḷu legalizācijas un terorisma finansēšanas novēršanas likums: LR likums. Available at http://likumi.lv/doc.php?id=178987 [last viewed November 1, 2016]. 
Considering these two criteria (close relationship; beneficial ownership) rebuttable assumptions can also be introduced in other cases, so that close persons must prove that they received specific property legally and in good faith.

If a principal or secondary participant of a crime acted for a third person and this person has directly received ill-gotten property, the confiscation of such property may be ordered against bona or mala fide persons. This suggestion is comparable to the principles of unjust enrichment that bona fide persons shall also return property obtained without legal grounds (Article 2387, 2388, 2376-2380 of the Civil Law).

Regardless of bona or mala fide, a third person must return criminally acquired property, or other property transferred to him on the basis of gratuitous transactions (Article 97 of the Insolvency Law; Article 1927 of the Civil Law).

If the third parties are not involved in a crime, but have indirectly received criminally acquired property or other property which has belonged to a perpetrator, for example, on the basis of a transaction, firstly, it should be determined, if all the legal conditions of the acquisition are fulfilled and it is lawful. Secondly, the "good faith" of that person should be established. Thirdly, the competent person must examine, if these persons have acquired property for consideration, i.e., the market value. ${ }^{31}$ When all these requirements are met, such person should be able to keep his property or get an adequate compensation from the state for the loss of the same property.

As to possible disputes between the owner (victim), who has lost his property due to a crime, and the bona fide acquirer of the Ownership (Article 927 of the Civil Law) or Pledge Right (Article 1278 of the Civil Law) on this property, the protection of the owner against the bona fide acquirer, or vice versa, cannot be called "fair" or "socially just", nor could the withholding of protection to either of them be called "unfair" or "socially unjust". ${ }^{22}$ The protection of the original owner against the bona fide acquirer, or vice versa, is a political decision. Normally, fundamental rights do not have a direct horizontal effect between individuals. Nevertheless, there is a case, in which the state can potentially violate the right to property of the bona fide acquirer. Article 360 of the Criminal Procedure Law stipulates that the things lost because of a crime shall be returned to its original owner or lawful possessor, but the bona fide acquirer is entitled to claim damages from an offender. This rule does not comply with Article 105 of the Constitution, when the bona fide acquirer practically cannot receive compensation because of prior confiscation, fine, or other compulsory sanctions of an economic nature, imposed on the alleged criminal's or convicted person's property. The possible solutions to this have been discussed above.

31 Forsaith J., Irving B., Nanopoulos E., Fazekas M. Technical report. Study for an impact assessment on a proposal for a new legal framework on the confiscation and recovery of criminal assets. Prepared for the European Commission Directorate General Home Affairs. RAND Europe, 2012, p. 30.

32 Faber W., Lurger B. (eds.). Rules for the transfer of movables: a candidate for European harmonisation or national reforms? München: Sellier, European Law Publishers, 2008, p. 148. 
Article 360 of the Criminal Procedure Law is also subject to diverse disputes in theory and practise. ${ }^{33}$ Moreover, the considerable latitude of authorities who are entitled to determine the real owner of criminally acquired property, in criminal proceedings, may lead to infringement of the right to property, because interference is often unforeseeable or arbitrary; and therefore incompatible with the principle of lawfulness. ${ }^{34}$

\section{Conclusions}

1. Bona fide or good faith is a lack of knowledge of a crime or other circumstances, which do not allow acquiring the right to property in the meaning of Article 105 of the Constitution.

2. The standard of bonus pater familias or reasonable person is helpful to specify the degree of care, which is required from bona fide persons.

3. In case of a close relationship to the criminal and beneficial ownership, rebuttable legal presumptions can be introduced that third persons have acted in bad faith, if they cannot prove the opposite. The rules of the Civil and Insolvency Law can be helpful in this regard.

4. The fundamental right to criminally obtained property shall be protected, if this right belongs to a bona fide person who legally acquired it for consideration.

5. Generally speaking, if civil claims of bona fide persons have not been settled before, or together with the decision on imposing of criminal penalties, or other compulsory sanctions with an economic nature, an offender can become insolvent; and he will not be able to satisfy civil claims of bona fide persons at the later stage of a criminal proceeding, or in subsequent civil proceedings.

6. One of the possible solutions would be to pass a rule that criminal penalties and other sanctions with economic effect set by the Criminal Law or Criminal Procedure Law are not executed, if claims of bona fide persons have not been satisfied or security has not been provided.

7. It may also be considered, if bona fide persons may receive an adequate monetary compensation from the public treasury, if the rights to property of bona fide persons have been infringed.

8. If a bona fide third person indirectly and lawfully received criminally acquired property or other property, which belonged to a criminal for consideration, i. e., market value, such person should be able to keep property or receive an adequate compensation from the state.

33 Kūtris G. Good Faith Recipient of Criminally Acquired Property: Two Laws and Two Solutions. In: "The Quality of Legal Acts and its Importance in Contemporary Legal Space", 4-5 October, 2012. Riga: University of Latvia Press, pp. 298-306.

34 Kolomijceva J. Īpašuma tiesību jautājumu taisnīgs noregulējums kriminālprocesā: mīts vai realitāte. In: Tiesību interpretācija un tiesỉbu jaunrade. LU 71. konferences rakstu krājums. Rìga: LU Akadēmiskais apgāds, 2013, pp. 94-106. 
9. The confiscation of criminally acquired property may be ordered against a bona or mala fide person, if a principal or secondary participant of a crime acted for this third person.

10. Criminally acquired property or other property may be confiscated, if a third person received it without consideration. Bona fide is not important in this case.

\section{BIBLIOGRAPHY}

\section{Literature}

1. Balodis K. Ievads civiltiesībās (Introduction to Civil Law). Rīga: Zvaigzne ABC, 2007.

2. Balodis K. Sicherungsübereignung im deutsch-lettischen Rechtsvergleich. Riga: Latvijas Universitāte, 2001.

3. Blaese H., Mende S. Lettlands Zivilgesetzgesetzbuch in Einzeldarstellungen vom 28. Januar 1937. Band II, 2. Das Sachenrecht. Riga: Verlag der AG "ErnstPlates", 1940.

4. Civillikumi ar paskaidrojumiem. Otrā grāmata. Lietu tiesības (Civil Law with Commentaries. $2^{\text {nd }}$ Book. Property Law). Sast. F. Konradi, A. Walter. Likuma teksts prof. Dr. iur. A. Būmaņa, H. Ēlersa un J. Lauvas tulkojumā. Rīga: Grāmatrūpnieks, 1935.

5. European Group on Tort Law. Principles of European Tort Law: Text and Commentary. Wien: Springer, 2005

6. Faber W., Lurger B. (eds.). Rules for the transfer of movables: A candidate for European harmonisation or national reforms? München: Sellier, European Law Publishers, 2008.

7. Kolomijceva J. Īpašuma tiesību jautājumu taisnīgs noregulējums kriminālprocesā: mìts vai realitāte (Fair regulation of property law issues in criminal proceedings: myth or reality?). In: Tiesību interpretācija un tiesību jaunrade. LU 71. konferences rakstu krājums, Rīga: LU Akadēmiskais apgāds, 2013, pp. 94-106.

8. Krastiņš U., Liholaja V., Niedre A. Krimināltiesības. Vispārīgā daḷa (Criminal Law. General Part) Trešais papildinātais izdevums. Zinātniskais redaktors prof. U. Krastiņ̌̌. Rīga: Tiesu namu aǵentūra, 2008.

9. Kūtris G. Good Faith Recipient of Criminally Acquired Property: Two Laws and Two Solutions. In: "The Quality of Legal Acts and its Importance in Contemporary Legal Space", 4-5 October, 2012. Riga: University of Latvia Press. pp. 298-306.

10. Leja L. Par labticīgā ieguvēja aizsardzību, prettiesiski atsavinot līzinga objektu (I) (Protection of bona fide acquirer in case of unlawful alienation of the leasing object ( $1^{\text {st }}$ part $)$ ). Available at http://www.juristavards.lv/doc/84089-par-labticiga-ieguveja-aizsardzibu-prettiesiskiatsavinot-lizinga-objektu/ / [last viewed September 30, 2016].

11. Lutzau H. von. Studien un Kritiken zum Ostseeprovinziellen Privatrecht. Erster Band. Riga: Verlang von Jonck und Poliewsky, 1908.

12. Torgāns K. Saistību tiesības. I daļa (Obligatory Rights. $1^{\text {st }}$ Part). Rīga: Tiesu namu aǵentūra, 2006.

13. Stessens G. Money Laundering: A New International Law Enforcement Model. Cambridge: Cambridge University Press, 2003.

14. Vettori B. Tough on Criminal Wealth: Exploring the Practice of Proceeds from Crime Confiscation in the EU. Dordrecht: Springer, 2006. 


\section{Legislative acts}

1. Latvijas Republikas Satversme (The Constitution of the Republic of Latvia): LR likums. Available at http://www.saeima.lv/en/legislation/constitution [last viewed November 1, 2016].

2. Civillikums (The Civil Law): LR likums. Available at http://likumi.lv/doc.php?id=225418 [last viewed November 1, 2016].

3. Krimināllikums (The Criminal Law): LR likums. Available at http://likumi.lv/doc. php?id=88966 [last viewed November 1, 2016].

4. Kriminālprocesa likums (The Criminal Procedure Law): LR likums. Available at http:// likumi.lv/doc.php?id=107820\#p626\&pd=1 [last viewed November 1, 2016].

5. Maksātnespējas likums (The Insolvency Law): LR likums. Available at http://likumi.lv/doc. php?id=214590 [last viewed November 1, 2016].

6. Noziedzīgi iegūtu līdzekḷu legalizācijas un terorisma finansēšanas novēršanas likums (The Law on the Prevention of Money Laundering and Terrorism Financing): LR likums. Available at http://likumi.lv/doc.php?id=178987 [last viewed November 1, 2016].

\section{Legal practice}

1. Decision of Grand Chamber of European Court of Human Rights, Case No. 39794/98 Gratzinger and Gratzingerova v. the Czech Republic.

2. Decision of Grand Chamber of European Court of Human Rights, Case No. 30210/96 Kudla v. Poland.

3. Dissenting opinion of Judge Pettiti, Judgment of European Court of Human Rights, Case No. 9118/80 Agosi v. the United Kingdom; Dissenting opinion of Judge Martens, joined by Judge Russo, Judgment of European Court of Human Rights, Case No. 18465/91 Air Canada v. the United Kingdom.

4. Judgment of European Court of Human Rights, Case No. 15375/89 Gasus Dosier- und Fördertechnik GmbH v.the Netherlands.

5. Judgment of European Court of Human Rights, Case No. 6833/74 Marckx v. Belgium.

6. Latvijas Republikas Satversmes tiesas 2003. gada 20. maija spriedums lietā Nr. 2002-21-01. Available at http://likumi.lv/doc.php?id=75081 [last viewed February 18, 2016].

7. Latvijas Republikas Satversmes tiesas 2005. gada 14. septembra spriedums lietā Nr. 2005-02-0106. Available at http://likumi.lv/doc.php?id=116761 [last viewed February 18, 2016].

8. Latvijas Republikas Satversmes tiesas 2005. gada 13. maija spriedums lietā Nr. 2004-18-0106. Available at http://www.satv.tiesa.gov.lv/wp-content/uploads/2016/02/2004-18-0106_ Spriedums.pdf [last viewed February 18, 2016].

9. Latvijas Republikas Satversmes tiesas 2006. gada 23. novembra spriedums lietā Nr. 2006-03-0106. Available at http://likumi.lv/ta/id/148871 [last viewed February 18, 2016].

10. Latvijas Republikas Satversmes tiesas 2009. gada 28. maija spriedums lietā Nr. 2008-47-01. Available at http://www.satv.tiesa.gov.lv/wp-content/uploads/2016/02/2008-47-01_ Spriedums.pdf [aplūkots 2016. gada 1. novembrī].

11. Latvijas Republikas Satversmes tiesas 2010. gada 7. decembra lēmums par tiesvedïbas izbeigšanu lietā Nr. 2010-31-01. Available at http://likumi.lv/doc.php?id=224057 [last viewed November 1, 2016]. 
12. Latvijas Republikas Satversmes tiesas 2012. gada 7. jūnija spriedums lietā Nr. 2011-19-01. Available at http://likumi.lv/doc.php?id=248964 [last viewed November 1, 2016].

13. Latvijas Republikas Augstākās tiesas Senāta Civillietu departamenta 2013. gada 10. oktobra spriedums lietā Nr. SKC-166/2013.

14. Latvijas Republikas Augstākās tiesas Senāta Civillietu departamenta 2008. gada 2. aprị̄a spriedums lietā Nr. SKC-143.

15. Latvijas Republikas Augstākās tiesas Senāta Krimināllietu departamenta 2008. gada 28. augusta lēmums lietā Nr. SKK-473/08.

16. Latvijas Republikas Augstākās tiesas Senāta Krimināllietu departamenta 2013. gada 23. maija lēmums lietā Nr. SKK-306/2013.

17. Rīgas apgabaltiesas Civillietu tiesu kolẹgijas 2015. gada 25. novembra lēmums lietā Nr. C30306315.

18. Rīgas apgabaltiesas Krimināllietu tiesu kolēgijas 2011. gada 1. novembra lēmums lietā Nr. 11816002109

19. Rīgas pilsētas Latgales priekšpilsētas tiesas 2011. gada 27. jūnija lēmums lietā Nr. 11816002809/K29-1122/11.

20. Rīgas rajona tiesas 2010. gada 15. jūnija lēmums lietā Nr. 11816000309.

21. Rìgas pilsētas Centra rajona tiesas 2010. gada 29. decembra lēmums lietā Nr. K-27-493/10/4.

22. Ventspils tiesas 2015. gada 4. jūnija spriedums lietā Nr. C33211215.

\section{Other sources}

1. Barkāns E. Dāvinājuma līgumi - fiktīvi darījumi? (Are Gift Contracts Fictitious Transactions?). Available at http://www.delfilv/news/comment/comment/elmars-barkans-davinajumaligumi-fiktivi-darijumi.d?id=13741585 [last viewed November 1, 2016].

2. Forsaith J., Irving B., Nanopoulos E., Fazekas M. Technical report. Study for an impact assessment on a proposal for a new legal framework on the confiscation and recovery of criminal assets. Prepared for the European Commission Directorate General Home Affairs. RAND Europe, 2012. 
Jan Provaznik, $M g$. iur.

Masaryk University, Czech Republic

\title{
BORDERS OF THE LANDSCAPE OF CRIMINAL PROCEDURE ERECTED BY THE ECHR ${ }^{1}$
}

\begin{abstract}
Summary
This paper deals with the interaction of the ECHR rights with the legislative power of member states of the CRHR regarding the criminal procedure. Its main thesis is that there is an ongoing process of quite substantial "demarcation" of the borders of the criminal procedure by the ECHR's case law that is usually perceived solely from the viewpoint of human rights protection, methodology included, but the perspective of criminal procedural law doctrine is mostly neglected. This might create difficulties when having to take both criminal-procedural law and the ECHR's case law into consideration, because a systematic and integrating analysis from both those standpoints has been prevalently missing.

This paper, therefore, tries to fill in this blank area by introducing a rather criminalprocedural-law oriented approach, adapting a new methodology suitable to achieve this goal and constructing an overview of approach while adopting a new criminal procedural legislation, which is "demarcation sensitive". It should help understanding the extent to which the legislator is limited when adopting a new law regarding the criminal procedure and to tie the two loose ends together.

At first, it marks the problematic points of methodology, then it sorts these points according to the categorization under the ECHR's case law, subsequently, it proceeds with re-categorizing under the structure of the criminal procedural law and submits a methodological algorithm to avert collision with the ECHR's conclusions. The categorization by ECHR's case law follows the human right in question according to the respective relevant article of the CPHR that the ECHR was applying, which are Art. 6, Art. 2, Art. 3, Art. 4, Art. 5 and Art. 8. The categorization by the criminal procedural law structure is scope of parties, position of criminal defence, evidence law, investigative measures and appellate procedures.
\end{abstract}

As the length of this paper is limited, it is restrained to giving just a brief systematic overview supplemented by a few particular observations to prove its correctness.

Keywords: criminal procedure, European Court of Human Rights, right to a fair trial.

\section{Introduction and the problems at hand}

The influence of the European Court for Human Rights in Strasbourg's (hereinafter "ECHR") case law on the member states' of the (European) Convention for

1 This paper has been created in the course of a specific research program of Masaryk university no. MUNI/A/1288/2015 "Adjustace specifických procesních otázek a koncepce trestního řízení" ("Adjustment of Specific Procedural Questions and the Concept of the Criminal Procedure"). This project focuses on different sources of adopting the criminal procedure to specific needs, of which the ECHR's case law is one. The proposed methodology is an original outcome of the project, published for the first time. 
the Protection of Human Rights and Fundamental Freedoms (hereinafter "CPHR") legal systems both on the level of the legislature and of the praxis and its constant growth in the past decades is undisputed. As this judicial body is vastly respected, though sometimes gruntingly, and as the spontaneous activity of the individual complainers as well as the widespread intended strategic litigation of human rights NGOs all around its jurisdiction is enormous, the ECHR gets more and more often to decide single cases on the grounds that might have serious general impact on the whole system of member state's law. ${ }^{2}$ Increasingly this impact often surpasses the borders of the member state involved and a minimal standard in a certain issue valid all over the member states is set.

As criminal procedure has always been associated with questions of paramount importance regarding the balance between individual rights and freedoms and the need to protect the whole society, the minimal standards of particular issues of the criminal procedure have been formulated up to a quite high systematic degree, touching pretty much every area of the criminal procedure matter. This development has, of course, meant a hardly trouble-free interaction with the legal system of the member states, especially with the legislative branch.

The perils of this interaction arise from several factors:

1) The member states' legislators usually operate by creating a keystone of several different sources of requirements that they have to weigh in, consequently, they do not necessarily see the ECHR's case law's requirements as unconditional, thus, in the states, where there is no particular emphasis upon human rights, implementation of ECHR's case law's requirements is quite hindered. ${ }^{3}$

2) The ECHR's case law is built on individual cases while the legislative branch should work exactly the other way around, but due to the conception of pilot cases, ECHR's case law has already adopted a general normative impact as well, ${ }^{4}$ even on the member states outside the particular case. ${ }^{5}$

3) Some ECHR case law's outputs are not easily recognisable, ${ }^{6}$ nor instinctively transferable to each member state's reality, as they do not prescribe precise

2 Keller H., Stone Sweet A. In: Keller H., Stone Sweet A. (eds.). A Europe of Rights: The Impact of the ECHR on National Legal Systems. Oxford: Oxford University Press, 2008. ISBN 13:9780199535262, p. 703.

3 Anagnoustou D., Mungiu-Pippidi A. Domestic Implementation of Human Rights Judgment in Europe: Legal Infrastructure and Government Effectiveness. The European Journal of International Law. 2014, Vol. 25, No. 1, p. 224.

4 Forst D. The Execution of Judgments of the European Court for Human Rights. Limits and Ways Ahead. ICL Journal, 2013, Vol. 13, No. 3, p. 19.

5 Helfer L. R., Voeten E. International Courts as Agents of Legal Change: Evidence from LGBT Rights in Europe. International Organization. 2014, Vol. 68, No. 1, p. 81af.

6 Bjorge E. Domestic Application of the ECHR: Courts as Faithful Trustees. Oxford: Oxford University Press, 2015. ISBN 978-0-19-874363-7, p. 151. 
measures that the government should adopt or the limits of its discretion. ${ }^{7}$ E.g., ECHR found DNA databases in breach with Art. 8 of the CPHR and glimpsed that this was because of a too broad scope of the permissible datacollecting, ${ }^{8}$ which implies that DNA samples' retention is not prohibited in absolute, but which also fails to provide any instructions as to how much "narrower" should be its scope.

4) Due to differences in individual member states' law, it might sometimes be difficult to establish, if a certain legal conclusion of the ECHR applies only to the specific law of the member state involved, of if it is a generally applicable rule. Especially, when the ECHR stipulates that in the given case the scope of margin of appreciation was exceeded, it is challenging for other states to determinate, whether their regulations or practices fall within that scope or not, as it is always contingent upon local conditions. ${ }^{9}$

5) ECHR's case law develops spontaneously, as individual complaints on particular problems occur, which makes relevant legal conclusions scattered, sometimes unbalanced throughout the matter, as some questions tend to appear much more often than others, and thus are hard to keep up-todate with, which is, e.g. the case of admissibility of evidence in the criminal proceedings. ${ }^{10}$ This leads to a state, in which there are rarely experts having both an accurate knowledge of ECHR case law and proficiency in the law of criminal procedure (or any other "simple" legal field).

6) The idea mentioned last is also demonstrated by the fact that human rights experts view the whole thing as a human rights problematic in a specific criminal law context, while criminal law experts perceive it as a singular human rights aspect of law of criminal procedure. The risk of missing something because of tunnel vision in both groups is thus imminent, yet not inevitable.

To fully surmount these factors a sensitive approach and clarity on the part of the ECHR is required, and on the part of the member states' legislators - a good orientation in its case law, as well as a sensitive approach, when adopting measures to cope with the ECHR's case law. But how can this be achieved?

7 Anagnoustou D., Mungiu-Pippidi A. Domestic Implementation of Human Rights Judgment in Europe: Legal Infrastructure and Government Effectiveness. The European Journal of International Law, 2014, Vol. 25, No. 1, p. 214.

8 Judgment of European Court for Human Rights, Case: 30562/04 30566/04 S. and Marper v. the United Kingdom, par. 125.

9 Stone Sweet A. The European Convention on Human Rights and National Constitutional Reordering. Cardozo Law Review, 2012, Vol. 33, No. 5, p. 1863.

10 Bachmaier Winter L. Transnational Criminal Proceedings, Witness Evidence and Confrontation: Lessons from the ECtHR's Case Law. Utrecht Law Review, 2013, Vol. 9, No. 3, p. 130-134, where a very brief and comprehensible overlook is given. 


\section{General methodological approach}

There are many ways to incorporate the ECHR's conclusions into a national legal order, ${ }^{11}$ including all branches of the government. ${ }^{12}$ This paper focuses only on the legislative coordination mechanism. ${ }^{13}$ An effective way for the legislator should consist of several steps, which might be described, as follows:

1) identify, what the ECHR's conclusion regards in the system of domestic law of criminal procedure-> 2) assess, which other systematic relations might be involved-> 3 ) determine, what kind of outcome the conclusion represents-> 4) assess, whether a domestic law system collides with the said conclusion-> 5) if so, determine what is the best solution, which is the most sensitive to the concept of the domestic law of criminal procedure.

Firstly, it is necessary to identify the relation between a certain EHCR's conclusion and a member state's criminal procedure from the systematic point of view, that is, to identify, which part of the member state's criminal procedure law is involved in its complexion and determine, how all of the other systematic relations of the part involved might be affected.

The first problem that we might encounter is different systematic of the ECHRs' case law-based doctrine and the criminal procedure's doctrine. Systematic distinction is not autotelic here, as it shows the dissimilar foundations, on which both of the doctrines are built. To be able to precisely mark the ECHR's case law's borders of the criminal procedure's law, it is essential to be able to translate it properly into the law of criminal procedure's law system and terminology.

From the human rights' point of view, following intersection with law of criminal procedure might be identified:

1) the "general" right to a fair process, enshrined in Art. 6, par. 1 of the CPHR (legal representation, access to a trial, equality of arms, delays of procedure minimization, etc.);

2) the "criminal" right to a fair process, which has special provisions of Art. 6, Sec. 2 and 3 of the CPHR (the right to remain silent and the nemo tenetur principle, ${ }^{14}$ access to evidence, the prohibition of entrapment, ${ }^{15}$ etc.);

11 See Keller H., Stone Sweet A. In: Keller H., Stone Sweet A. (eds.). A Europe of Rights: The Impact of the ECHR on National Legal Systems. Oxford: Oxford University Press, 2008. ISBN 13:9780199535262, p. 682 af.

12 Report on the Implementation of International Human Rights Treaties in Domestic Law and the Role of Courts adopted by the Venice Commission at its 100th plenary session (Rome, 10-11 October 2014) Study No. 690/2012, p. 23. Available at http://www.venice.coe.int/ webforms/documents/?pdf=CDL-AD(2014)036-e\# [last viewed August 31, 2016].

13 Keller H., Stone Sweet A. In: Keller H., Stone Sweet A. (eds.). A Europe of Rights: The Impact of the ECHR on National Legal Systems. Oxford: Oxford University Press, 2008. ISBN 13:9780199535262, p. 687.

${ }_{14}$ Grabenwarter Ch., In: Ehlers D., Becker U. (eds.). European Fundamental Rights and Freedoms. Berlin: De Gruyter Recht, 2007, p. 165.

15 Mahoney P. Right To A Fair Trial In Criminal Matters Under Article 6 E.C.H.R. Judicial Studies Institute Journal, 2004, Vol. 4, No. 2, p. 114. 
3) the right to an effective investigation, as it follows from Art. 2, 3, $4^{16}$ of the CPHR (positive obligation of the state to run an investigation, when one of these articles is triggered);

4) the right to life and the prohibition of torture, enshrined in Art. 2 and 3 of the CPHR (inviolability of suspects, the modified fruit from the poisonous tree doctrine, etc.);

5) the right to liberty and security as enshrined in Art. 5 of the CPHR (apprehension and detention limitation);

6) the right to respect for family and private life, enshrined in Art. 8 of the CPHR (home searches' limitation, private correspondence secrecy, tapping limitations ${ }^{17}$ ).

Generally, it could be said that although the shape of criminal procedure has mostly been determined by the right to a fair trial awarded to the defendant; rights of the victims have proven to be a useful chisel, as well. The effective investigation doctrine has had some particularly significant impact on the criminal procedure. The aforementioned six circles of human rights' and criminal procedures' intersection can be re-estimated under the criminal procedure terminology and systematic, as follows:

1) the basic principles regarding the initiation of the proceedings (right to an effective investigation);

2) the basic principle of economy and speediness of a criminal procedure (minimization of delays);

3) evidence law (nemo tenetur principle, inviolability of suspects, access to evidence);

4) securing instruments (search, apprehension, tapping and detention warrants);

5) operative-investigative instruments (prohibition of entrapment);

6) rights of the defence (legal representation, equality of arms, access to a trial). This scheme is definitely not exhausting, as there are many more intersections to be identified. Rather than describing an encompassing overview of the "human-right to criminal-procedural and back" dictionary, I will later turn to demonstrating the need for a systematic sensitive approach and its possible consequences on particular topics.

Secondly, a thorough analysis of all the overlaps of the correctly systemized problem into other portions of the law of criminal procedure's matter is needed. This follows from the previous step, which has shown us that the law of criminal procedure doctrine and the ECHR's case law's doctrine are based on a different systemization. The tricky part here is that the ECHR's case law usually tackles the problematic

16 Judgment of European Court for Human Rights, Case No. 25965/04 Rantsev v. Cyprus and Russia, par. 288.

17 Akkaraca Köse M. In: Akrivopoulou Ch., Psygkas A. (eds.). Personal Data Privacy and Protection in a Surveillance Era: Technologies and Practices. New York: Information Science Reference, 2011, p. 75. 
aspect more narrowly than the law of criminal procedure doctrine. That is only natural, as it stems from the different sources and different aims of both doctrines. It is not ECHR's job to analyse all the possible impacts on domestic particular field of law's system or even the domestic legal order as a whole. On the other hand, it is a crucial task for the domestic legislator. Being able to identify every possible impact of a certain conclusion of the ECHR is thus a necessity before adopting a new regulation. It is worth mentioning here that several member states have established specialized institutions, whose task is to monitor the compliance of national law with the obligations set forth by the ECHR to satisfy this need. ${ }^{18}$

The third step that I mentioned above determines the kind of outcome a particular ECHR's conclusion represent. This typology consists of strict rules, which can be further divided into strict prohibitions, rigorous conditions and scrutiny (which are more common), which can have a form of a test or a set of factors:

- strict prohibitions are e.g. the illimitability of the right to remain silent to just specific sort of crimes based on their seriousness ${ }^{19}$ or to procedural strategies of the defendant that would not delay the proceedings ${ }^{20}$ or the inadmissibility of putting any burden of proof on a victim of a rape to prove she/he resisted); ${ }^{21}$

- strict conditions are e.g. the structural independence of the prosecuting and the adjudicating body $y^{22}$ or a good faith of any investigation ${ }^{23}$ );

- with tests, specific steps have to be followed, e.g. the test of admissibility of a testimony, where the defence has not had an opportunity to examine the witness, consisting of $i$.) whether there was a good reason for the admission of the absent witness's untested statements as evidence; ii.) whether the evidence of the absent witness was the sole or decisive proof of guilt; and iii.) whether there was a sufficient procedural compensation for the handicaps of the defence; ${ }^{24}$

- a set of factors prescribes multiple viewpoints that have to be taken into account, when deciding a specific question, e.g. the gravity of the anonymous

18 Caligiuri A., Napoletano N. The Application of the ECHR in the Domestic Systems. In: Conforti B. et al. The Italian Yearbook of International Law. Leiden: Martinus Nijhoff Publishers, 2010, Vol. 20, p. 147.

19 Judgment of the European Court for Human Rights, Case No. 19187/91 Saunders v. the United Kingdom, par. 74.

20 Judgment of European Court for Human Rights, Case No. 35848/9, Barfuss v. the Czech Republic, par. 81 .

21 Judgment of European Court for Human Rights, Case No. 39272/98 M. C. v. Bulgaria, par. 166.

22 Judgment of the European Court for Human Rights, Case No. 46387/99, 48906/99, 57410/00 and 57419/00 Whitfield and others v. the United Kingdom, par. 45.

23 Judgment of European Court for Human Rights, Case No. 11209/84; 11234/84; 11266/84; 11386/85 Brogan and others v. the United Kingdom, par. 53.

${ }^{24}$ Judgment of the European Court for Human Rights, Case No. 9154/10 Schatschaschwili v. Germany, par. 107. 
witness' testimony, its genuineness and the legitimacy of the reasons why the anonymous status was granted. ${ }^{25}$

The fourth aforementioned step is an analysis of the compatibility of the domestic legal order with the requirements set up by the ECHR's case law. Two situations occur here - when the case in question was "domestic state's own" and when it was not. It might seem that the first situation is pretty easy for the domestic state, as the ECHR assessed its national law and found a flaw in it, giving rise to breaches of the CPHR. Alas, things are not always that simple. In some cases, the ECHR expresses explicitly what was wrong and what the right approach should have looked like, but in other cases it limits itself to indicating that a certain course of action was wrong without giving any instruction as to how the state should behave in its domestic situation to amend it (see below the Brogan case remark).

The second aforementioned situation aims at the cases, in which the other member states different from the contested one tend to deal with the matter at hand similarly to the contested one and wonder, whether their distinctions would hold up in the face of a potential complaint to the ECHR based on the same grounds. This situation is probably the most difficult and requires the most detailed knowledge of the ECHR's conclusions, their context and consequences, as using an in concreto rule to assess an abstract system is quite challenging and mostly based solely on prediction of what would have happened had the ECHR examined our law instead of the one it did.

The fifth and last step is then its own space, within which the legislator might assert the political will. As long as it finds itself in compliance with the ECHR's case law "prerequisites" and therefore inside the borders drawn by the ECHR, the field is free.

\section{Demonstration on the basis of specific examples}

\subsection{Proper systematic categorization and finding all of the systemic relations}

This can be demonstrated on the Czech solution to the right to be heard at a court in connection with the custody proceedings. This issue was, in my opinion, solved in a bit overstretched manner. Prior to amendment to the Czech Code of Criminal Procedure (hereinafter - "CPP") ${ }^{26}$ by law No. 459/2011 Coll., the power to prolong the custodial detention was given to the prosecutor, whose decision could have been reviewed by a court. The system of reviewing the legitimacy of the custodial detention was doubled - there was an obligation of the prosecutor to reassess the duration of the reasons do pre-trial custodial detention in certain periods, and the detainee himself/herself could have filed a petition for hers/his release. As follows from the ECHR's case law, this dual system is not even necessary to comply

25 Judgment of the European Court for Human Rights, Case No. 20524/92 Doorson v. the Netherlands, par. 75 and 76.

26 Law No. 141/1961 Coll., on Criminal Judicial Procedure (Code of Criminal Procedure), as amended. 
with the requirements of Art. 5, par. 4 of CPHR. ${ }^{27}$ The decisions of the prosecutor, regardless of the mechanism that had led to it, were challengeable by a complaint of the detainee to a court. Courts usually decided these complaints without hearing in a procedural form of the so-called non-public session. Although the ECHR had approved praxis of the court resting in not hearing the detainee, automatically every time his/hers custodial detention had been examined, ${ }^{28}$ the Czech praxis was criticized by the Czech Constitutional Court, ${ }^{29}$ resulting into the derogation of the provision of the CPP restricting access to non-public hearing to anybody else but the judges and protocol clerk..$^{30}$

It was therefore decided that the detainee had a right to be heard even in the proceedings regarding prolongation of the detention. All of these decisions were, nevertheless, preceded by an isolated resolution of the Constitutional Court that had upheld the previous praxis of the non-public sessions of the criminal courts, ${ }^{31}$ which had been challenged with a complaint to the ECHR, that could not have been any other than successful. The ECHR even mentioned a newer case law of the Czech Constitutional Court, which had changed the praxis. ${ }^{32}$ However, when introducing the abovementioned amendment of the CCP, this judgment of the ECHR was named in the explanatory report as one of the main reasons (alongside the already developed case law of the Czech Constitutional Court) to introduce a specific new form of session of the criminal court, the so-called custodial session. ${ }^{33}$

The custodial session, now regulated in sec. $73 \mathrm{~d}$ and following of the CCP, definitely satisfies all the requirements of the ECHR's case law regarding the right of the detainee to be heard. Every decision (except the decision to release the detainee) on custodial detention now falls within the power of the court, the detainee has to be present at a court hearing every time the prolongation of his/her detention is being decided, etc. In spite of that, the systematic connotations of the Czech criminal procedure have been neglected. Prior to law No. 459/2011 Coll., CCP knew three forms of court's sessions - the main hearing, dedicated to the assessment of the merit of the case, the public session, designed to procedural questions that require the presence of the parties (usually because evidence process takes place in them) and the non-public session, reserved for procedural questions that can be addressed without the presence of the party (typically, when the court decides

27 Judgment of European Court for Human Rights, Case No. 30779/04 Patsuria v. Georgia, par. 55, judgement of European Court for Human Rights, Case No. 37048/04 Nikolaishvili v. Georgia, par. 85 .

28 Judgment of the European Court for Human Rights, Case No. 45466/99 and 29903/02 RahbarPagard v. Bulgaia, par. 67.

29 For example finding of the Constitutional Court of the Czech Republic of 20. 4. 2004, file number I.ÚS 573/02.

30 Finding of the Constitutional Court of the Czech Republic of 27. 4. 2005, file number Pl. ÚS 45/04.

31 Resolution of the Constitutional Court of the Czech Republic of 19. 2. 2004, file number III. ÚS 544/03.

32 Judgment of the European Court for Human Rights, Case No. 19970/04 Husšák v. the Czech Republic, par. 44.

33 Explanatory report to the law No. 459/2011 Coll., p. 35. Available at https://www.psp.cz/sqw/text/ orig2.sqw? idd=70587\&pdf $=1$ [last viewed March 8, 2017]. 
legal remedies, designated solely to correct the errors of law, and both parties had a chance to express their positions on that issue).

The systemization of these types of court's sessions was quite simple - one for dealing with the question of guilt and punishment "in full armour", another, less formal, for procedural questions when the attendance of the parties is vital, and yet another for procedural questions, when the attendance of the parties is not needed. The custodial session combines the traits of both non-public session and the public session, ${ }^{34}$ thus creating a hybrid. With a non-public session it shares the exclusion of the public, because only the prosecutor and the defendant are present, which is, on the other hand, a constitutive trait of a public session (where the public is usually allowed, but the essence lies in enabling the parties to present their procedural standpoints in a contradictory fashion).

Such a particular special regulation of deciding on one specific problem undermines the system as a whole, because it raises questions as to why the modification of already existing forms was not sufficient. The same outcome would have been achieved had the legislator prescribed a form of public session for cases, in which the ECHR's and the Constitutional Court of the Czech Republic's case law demanded full procedural guarantees and a non-public session, where the case law enables it. There would not have been a slightest problem to exclude the public from the public session on custodial detention (although it is not clear why the public is excluded from the custodial session in the first place) or to prescribe an obligatory presence of the detainee in it (as in general is, for example, the case with public session on appeal). This regulation would be much more coherent with the system of the Czech criminal procedure and would not raise the doubts attached to the desirability of introducing a brand new form of court's session.

Of course, from the practical perspective, this regulation does not present any insurmountable obstacles, since, as I stated above, the differences are minor. However, it is quite a good example to illustrate neglecting of the systemic relation.

\subsection{Determining the nature of the conclusion}

Problem very often lies in the fact that the Court does not provide the composition of the whole scrutiny in one place, therefore necessitating to put them together from several parts of one judgement, or even from several judgments. Above I mentioned the Schatschaschwili case, in which the ECHR composes the test as described above, referring to the Taxquet case. ${ }^{35}$ The referred judgment, however, did not set forth this test in an expressly articulated manner, which is what the ECHR did in the Schatschashwili case for the first time. The point here is that in the Taxquet case, the said composition had to be extracted by the ECHR from its text, which is something that definitely does not contribute to the transparency and clarity of the ECHR's case law. Such an "extraction process" is undesirable, of course, since it is inevitably accompanied by a great deal of interpretation discords.

\footnotetext{
${ }_{34}$ Šámal P. In: Šámal P. a kol. Trestní řád. Komentár. 6. vydání. Praha: C. H. Beck, 2013, p. 927.

35 Judgment of European Court for Human Rights, Case No. 927/05 Taxquet v. Belgium.
} 
Another problem is that quite often the ECHR, trying to keep its review as close to the individual fact of the case as possible, restrains to pronounce that some practice is unacceptable without indicating, which one would be acceptable. For example, in the Brogan case, the ECHR concluded that a detention without a judicial decision for the duration of four days and six hours is unacceptable. ${ }^{36}$ Nevertheless, it did not (intentionally) shed any light as to the longest acceptable period. Enough to say, the Commission itself was of the opinion that the four day period should be acceptable in ordinary criminal cases, and it went as far as envisage that this period could be even longer in terrorism-related cases. ${ }^{37}$ This is quite a good example of how the ECHR's case law might be puzzling, as in a later decision a period exceeding six days was accepted, even though the only review was conducted by a superior police body. ${ }^{38}$

\subsection{The issues of compatibility of state's domestic law with the ECHR's case law}

In this respect, another case from the Czech Republic serves as a rather suitable example. The doctrine of right to an effective investigation of the victim under Art. 2, 3 and 4 (at least), especially in the cases of deaths, where agents of the state might have been involved, is a stable and ever-growing chapter of the ECHR's case law. All of its core parts, including the independence ${ }^{39}$ of the investigation, have therefore been known for quite a long time. The ECHR's hard stance on effective investigation in such cases ${ }^{40}$ including such a strong conclusion that even a background of a military conflict does not waive this duty has been notoriety no later than from the 1990s.

The Czech Republic thus was well aware of all its components, nevertheless the ECHR found a breach of the right to an effective investigation, resting in the absence of an independent investigative body in cases of alleged crimes, committed by law enforcement officers. The factual circumstances of this case revolved around an uncertain death of a young Roma, apprehended by the police officers as a suspect of a crime, who allegedly broke out of their hands, while being escorted from a toilet and jumped out of a window. Surprisingly, the ECHR stayed quiet on the racial background of this case ${ }^{41}$ and focused mainly on the conduct of the investigation.

36 Judgment of European Court for Human Rights, Case No. 11209/84; 11234/84; 11266/84; 11386/85 Brogan and Others v. the United Kingdom, par. 62.

37 Tanca A. Human Rights, Terrorism and Police Custody: The Brogan Case. European Journal of International Law, 1990, Vol. 1, No. 1, p. 272 af.

38 Judgment of European Court for Human Rights, Case No. 14553/89; 14554/89 Brannigan and McBride v. the United Kingdom.

39 Smith G. The Interface between Human Rights and Police Complaints in Europe. In: Civilian Oversight of Police: Advancing Accountability in Law Enforcement. Boca Raton: Taylor \& Francis Group, 2016, ISBN 139781482234206, p. 173.

40 Chevalier-Watts Jt. Effective Investigation under Article 2 of the European Convention on Human Rights: Securing the Right to Life or an Onerous Burden on the State? In: The European Journal of International Law. 2010, Vol. 21, No. 3, p. 707.

41 Peroni L., Timmer A. Vulnerable groups: The promise of an emerging concept in European Human Rights Convention law International Journal of Constitutional Law, 2013, Vol. 11, No. 4, p. 1070. 
At that time, the Inspection of the Ministry of Interior conducted investigation of these cases with support from internal Group of Control and Complaints, inherent to the police structure and although the Inspection was formally independent on the police, it was directed by the same ministry. ${ }^{42}$ As a result, a new institution (General Inspection of Armed Corps) replacing the former Inspection was established, independent even of the Ministry.

\subsection{Choosing the best solution}

Picking the best solution is, to a large extent, dependent upon the success of the legislator in conducting the previous steps, especially on the precision with which he was able to identify the scope of the problem and its systematic overlaps. The states usually tend to take the safest road and adopt measures that even exceed the requirements of the ECHR's case law. For example, in connection with the aforementioned testimonies of anonymous witnesses, the Dutch Supreme Court chose to prohibit the use of hearsay testimony by anonymous witnesses, while the French Cassation Court just tightened the conditions, under which such a testimony, uncontested by contradictory examination, is admissible. ${ }^{43}$

\section{Conclusions}

There are many factors that obscure clear identification of all the borders for a domestic law of criminal procedure that the ECHR has drawn in its case law, namely, different modes of activity of the domestic legislator and the ECHR, their different starting positions, difficulties with naming the precise conclusion in a particular decision, challenges with "grafting" conclusion regarding a slightly different legal order of another member state of the CPHR into the domestic legal conditions, spontaneous and sometimes confusing development of the ECHR's case law, selectivity of an approach from human rights' perspective and from criminal procedure doctrine's perspective.

When assessing an impact of any ECHR's conclusion into a domestic law of criminal procedure, different terminology and systemization therefore have to be taken into consideration and a specific algorithm of implementing has to be exercised:

1. "translation" of the ECHR's conclusion into the terminology of the law of criminal procedure;

2. consideration of all the existing systematic interconnections;

3. determination of the type of limit of the ECHR's conclusion;

4. assessment of the domestic legal order consistency with it; and

42 Judgment of European Court for Human Rights, Case No. 23944/04 Eremiášová and Pechová v. the Czech Republic, par. 154.

43 Jackson J. D., The Effect of Human Rights on Criminal Evidentiary Processes: Towards Convergence, Divergence or Realignment? The Modern Law Review, 2005, Vol. 68, No. 5, p. 753. 
5. eventual determination of what would be the best way to amend the legislation.

Obviously, quite a long road has to be travelled before the legislator can exert its political will, which shows how much the ECHR intervenes not only in everyday legal praxis, but also in political, as well as technical part of legislation-making. This paper was conceived from the point of view toward adopting ECHR's case law into domestic legal order, but its remarks are mutatis mutandis applicable also from the other point of view - where the legislator wants to change the law of criminal procedure on his own.

\section{BIBLIOGRAPHY}

\section{Literature}

1. Akkaraca Köse M. In: Akrivopoulou Ch., Psygkas A. (eds.). Personal Data Privacy and Protection in a Surveillance Era: Technologies and Practices. New York: Information Science Reference, 2011, p. 75.

2. Anagnoustou D., Mungiu-Pippidi A. Domestic Implementation of Human Rights Judgment in Europe: Legal Infrastructure and Government Effectiveness. The European Journal of International Law, 2014, Vol. 25, No. 1.

3. Bachmaier Winter L. Transnational Criminal Proceedings, Witness Evidence and Confrontation: Lessons from the ECtHR's Case Law. Utrecht Law Review, 2013, Vol. 9, No. 3.

4. Bjorge E. Domestic Application of the ECHR: Courts as Faithful Trustees. Oxford: Oxford University Press, 2015. ISBN 978-0-19-874363-7.

5. Caligiuri A., Napoletano N. The Application of the ECHR in the Domestic Systems. In: Conforti B. et al. The Italian Yearbook of International Law. Leiden: Martinus Nijhoff Publishers, 2010, Vol. 20.

6. Chevalier-Watts, Jt. Effective Investigation under Article 2 of the European Convention on Human Rights: Securing the Right to Life or an Onerous Burden on the State? In: The European Journal of International Law, 2010, Vol. 21.

7. Explanatory report to the law No. 459/2011 Coll., p. 35. Available at https://www.psp.cz/ sqw/text/orig2.sqw?idd=70587\&pdf $=1$ [last viewed March 8, 2017].

8. Forst D. The Execution of Judgments of the European Court for Human Rights. Limits and Ways Ahead. ICL Journal, 2013, Vol. 13, No. 3.

9. Grabenwarter Ch. In: Ehlers D., Becker U. (eds.). European Fundamental Rights and Freedoms. Berlin: De Gruyter Recht, 2007.

10. Helfer L. R. Voeten E. International Courts as Agents of Legal Change: Evidence from LGBT Rights in Europe. International Organization, 2014, Vol. 68, No. 1.

11. Jackson J. D. The Effect of Human Rights on Criminal Evidentiary Processes: Towards Convergence, Divergence or Realignment? The Modern Law Review, 2005, Vol. 68, No. 5.

12. Keller H., Stone Sweet A. In: Keller H., Stone Sweet A. (eds.). A Europe of Rights: The Impact of the ECHR on National Legal Systems. Oxford: Oxford University Press, 2008, ISBN 13:9780199535262.

13. Mahoney P. Right To A Fair Trial In Criminal Matters Under Article 6 E.C.H.R. Judicial Studies Institute Journal, 2004, Vol. 4, No. 2. 
14. Peroni L., Timmer A. Vulnerable groups: The promise of an emerging concept in European Human Rights Convention law International Journal of Constitutional Law, 2013, Vol. 11, No. 4.

15. Report on the Implementation of International Human Rights Treaties in Domestic Law and the Role of Courts adopted by the Venice Commission at its $100^{\text {th }}$ plenary session (Rome, 10-11 October 2014) Study No. 690/2012. Available at http://www.venice.coe.int/ webforms/documents/?pdf=CDL-AD(2014)036-e\# [last viewed August 31, 2016].

16. Šámal P. In: Šámal P. a kol. Trestní raád. Komentář. 6. vydání. Praha: C. H. Beck, 2013.

17. Smith G. The Interface between Human Rights and Police Complaints in Europe. In: Civilian Oversight of Police: Advancing Accountability in Law Enforcement. Boca Raton: Taylor \& Francis Group, 2016, ISBN 139781482234206.

18. Stone Sweet A. The European Convention on Human Rights and National Constitutional Reordering. Cardozo Law Review, 2012, Vol. 33, No. 5.

19. Tanca A. Human Rights, Terrorism and Police Custody: The Brogan Case. European Journal of International Law, 1990, Vol. 1, No. 1.

\section{Legislative acts}

1. Convention on Protection of Human Rights and Fundamental Freedoms.

2. Law No. 40/2009 Coll., Criminal Code, as amended.

\section{Legal practice}

1. Finding of the Constitutional Court of the Czech Republic of 27.4.2005, file number Pl. ÚS 45/04.

2. Finding of the Constitutional Court of the Czech Republic of 20.4.2004, file number I.ÚS 573/02.

3. Judgment of European Court for Human Rights, Case No. 11209/84; 11234/84; 11266/84; 11386/85 Brogan and others v. the United Kingdom.

4. Judgment of European Court for Human Rights, Case No. 25965/04 Rantsev v. Cyprus and Russia.

5. Judgment of European Court for Human Rights, Case No. 30562/04 30566/04 S. and Marper v. the United Kingdom, par. 125.

6. Judgment of European Court for Human Rights, Case No. 30779/04 Patsuria v. Georgia.

7. Judgment of European Court for Human Rights, Case No. 37048/04 Nikolaishvili v. Georgia.

8. Judgment of European Court for Human Rights, Case No. 35848/9 Barfuss v. the Czech Republic.

9. Judgment of European Court for Human Rights, Case No. 39272/98 M. C. v. Bulgaria.

10. Judgment of European Court for Human Rights, Case No. 927/05 Taxquet v. Belgium.

11. Judgment of European Court for Human Rights, Case No. 14553/89; 14554/89 Brannigan and McBride v. the United Kingdom.

12. Judgment of European Court for Human Rights, Case No. 23944/04 Eremiášová and Pechová v. the Czech Republic.

13. Judgment of the European Court for Human Rights, Case No. 19187/91 Saunders v. the United Kingdom. 
14. Judgment of the European Court for Human Rights, Case No. 19970/04 Hušák v. the Czech Republic.

15. Judgment of the European Court for Human Rights, Case No. 20524/92 Doorson v. the Netherlands.

16. Judgment of the European Court for Human Rights, Case No. 45466/99 and 29903/02 Rahbar-Pagard v. Bulgaia.

17. Judgment of the European Court for Human Rights, Case No. 46387/99; 48906/99; 57410/00 and 57419/00 Whitfield and others v. the United Kingdom.

18. Judgment of the European Court for Human Rights, Case No. 9154/10 Schatschaschwili v. Germany.

19. Resolution of the Constitutional Court of the Czech Republic of 19. 2. 2004, file number III. ÚS 544/03. 


\section{SECTION 4}

\section{THE ROLE OF PRIVATE LAW IN REINFORCING CONSTITUTIONAL VALUES}


Inga Kudinaviciute-Michailoviene, $\mathrm{PhD}$

Mykolas Romeris University, Lithuania

Ausra Maslauskaite, $\mathrm{PhD}$

Vytautas Magnus University, Lithuania

\title{
ENFORCEMENT OF PARENTAL OBLIGATIONS: LEGAL AND SOCIOLOGICAL ASPECTS OF CONTACT AND MAINTENANCE ARRANGEMENTS
}

\begin{abstract}
Summary
The Constitution of the Republic of Lithuania provides that the family is under the protection and care of the state. Perception of the family as of a constitutional value, implies, among other things, the enforcement of rights and obligations of individual family members. These include the right of children to adequate maintenance and the right of parents to parental authority with regard to their children (e.g., the right to contact their children and to participate in their upbringing). Despite the existing regulation, children's rights to maintenance and to participation of both parents in their upbringing and communication with them are often not properly implemented after the dissolution of marriage or separation of their parents.

Analysis of the case law (both national and that of the ECHR) leads to a conclusion that quite often one of the parents (or sometimes both of them) abuses the parental authority and fails to ensure the child's right to maintain personal contacts with the second parent, thus not only breaching the child's rights but also setting limitations to the second parent's involvement in tackling various issues related to the child's interests. A proper implementation of maintenance obligations depends on both subjective and objective circumstances, e.g., material wealth of the parents (income and property), the number of dependents, etc. Timely fulfilment of the parental obligations becomes even more complicated when the parents reside in two different states. To resolve the disputes with a cross-border element, the states resort to the specialised legal instruments, such as Council Regulations, The Hague Conventions, etc.

This paper is based on the findings of a representative survey of fathers living separately from their children after dissolution of their partnership with children's mothers, carried out in Lithuania. It analyses how these fathers estimate the fairness of contact and maintenance arrangements set by the court, as well as their subjective explanations of the reasons for the court decisions deemed by them as unfair.
\end{abstract}

Keywords: parental obligations, maintenance, contact order.

\section{Introduction}

Due to the free movement of persons in the EU, variety of family forms and models of child upbringing become a common and tolerable phenomenon. In the recent 
decade, Lithuania has been facing high migration rates $^{1}$ and the emergence of a transnational family model. ${ }^{2}$ The courts are increasingly involved in disputes related with the establishment of the child's place of residence, and maintenance obligations. The number of cases related to the civil aspects of child abduction is also growing.

Lithuania is among those Europeans states, where divorce rates have been high for several decades ${ }^{3}$ and this, undoubtedly, brings certain implications for the enforcement of child maintenance obligations. The case law of the Supreme Court of Lithuania (hereafter - SCL) have already provided some criterions related to children maintenance. Unfortunately, the case law related to children contact order and participation in their education is still evolving. Considering the existing social, economic, legal and other changes and sustaining both the analysis of court practice and doctrine attitude, the article analyses the present topicality concerning contact regime with children and their maintenance order. To implement the paper's aim, the theoretical and empiric scientific methods have been used in research.

\section{Contact regime and participation in the upbringing of children}

Possibility to maintain contact with both parents is a key right of any child. The law must guarantee child's continuous right to contact with both parents, regardless of whether they live together or separately, with a special emphasis on joint upbringing. Such position is stated in various legal instruments (e.g. the UN Convention on the Rights of the Child), as well as in the principles of the Commission on European Family Law (CEFL) related to the parental responsibilities. ${ }^{4}$ Establishment of the child's place of residence is closely linked with the establishment of the contact regime and participation in the upbringing of the child for the non-residential parent, therefore these two decisions should normally be taken together. The parents may conclude a written or oral agreement on the contact regime and participation in the upbringing of the child. Upon failure to reach such agreement, or in cases when one of the parents fails to keep the oral agreement, the contact regime and participation in the upbringing of the child is set by the court.

1 The number of persons who declared emigration increased from 7,523 (2001) to 83,577 (2010) and 54,331 (2011). Lithuania's emigration index per thousand residents is the highest in the EU. // European Migration Network. Available at http://123.emn.lt/lt/bendros-tendencijos/migracija10-metu-apzvalga [last viewed August 22, 2016].

2 A family, whose members reside in different national states and daily routine transcend all boundaries of a single national state. Such lifestyle brings essential transformation to the family and modifies its functions. Maslauskaite A., Stankūnienè. Šeima abipus sienų: Lietuvos transnacionalinès šeimos genezè, funkcijos, raidos perspektyvos [Family Across Frontiers: Genesis, functions and development prospective of trans-national families in Lithuania]. Vilnius: International Organization for Migration, Institute of Social Research, 2007.

3 In 2014, crude divorce rate in Lithuania was 3.3. The total divorce rate was 0.43 , which indicates that the probability of divorce reaches $43 \%$. In 2014 , over a half (54.2\%) of all divorced couples had common children under 17 years of age. Following the divorce, 7,400 children were left in single parent (mostly single mother) families. Demographic Yearbook 2014, pp. 106-110.

4 Boele-Woelki K. and others. Principles of European Family Law regarding Parental Responsibilities. Intersentia, 2007. 
According to the Lithuanian legislation (e.g. Art. 3.155, 3.156, and 3.170 of the Civil Code), both parents, regardless of their matrimonial status, have the right and responsibility to bring up and nurture their children, to take care of their health, to provide maintenance and favourable conditions for their broad and balanced development, with consideration of their mental and physical state, in order to prepare them for an independent life within society. The residential parent is more deeply involved in the upbringing of the child, but that neither diminishes the right of the non-residential parent to participate in that process, nor exempts him/her from that duty. To that end, the law obliges the residential parent to refrain from any obstruction of the communication of the non-residential parent with the child and participation in his/her upbringing. This principle was established also in the interest of children, so that they could be brought up by both parents. ${ }^{5}$

While communicating with the child, both parents should aim to contribute to his/her upbringing, rather than to merely meet the child. Visitation rights differ from the right of contact with a separately living child. The right of contact is a means to secure permanent and direct involvement in the upbringing of a child, when the child's place of residence has been established with another parent, while the visitation rights are provided by the law in order to prevent the loss of child's bonds with the non-residential parent. ${ }^{6}$ Therefore both parents must have equal opportunities to communicate with the child, except for the time he/she spends sleeping, studying, attending various educational activities, playing with peers, etc. Communication may take place both in the form of direct meetings and by electronic means of communication (Skype, etc.).

Lithuanian case law sets priority on maximum communication with the child. The principle of maximum involvement in the upbringing of child (Art. 3.175, point 2 of the CC) means that no restrictions should be made to the non-residential parent's access to the child, unless required by the best interests of the child. The courts issuing rulings on the maximum or minimum contact regime should assess, whether the maximum regime proposed by one of the parties is in the best interests of the child, and whether the age and daily agenda of the child would not render the ruling practically unenforceable. Following the best interests of the child, the court must also take into consideration the mutual relationship of the parents, their behaviour, their place of residence and material circumstances, as well as the attitude of other family members towards the child, etc. ${ }^{7}$ In each case, the contact regime should be tailored to meet the best interests of the child and to be feasible for the non-residential parent. Case law analysis (covering both national courts and the ECHR) suggests that most problems related to the inappropriate enforcement of the right of contact or failure thereof occur in cases, when the parents reside in different countries. Restrictions of the contacts with the child are often initiated

Ruling of the Supreme Court of Lithuania of 8/05/2005 in Civil Case No. 3K-3-30/2005

6 Šeimos bylų nagrinejjimo ir teismo sprendimų vykdymo ypatumai. Mokslo studija. Vilnius: MRU, 2013, pp. 80-87. Tamošiūnienè E., Kudinavičiūtè-Michailovienė I. (eds.). Family Cases: Adjudication and Enforcement. Scientific study. Vilnius: Mykolas Romeris University, 2013, p. 77.

7 Ruling of the Supreme Court of Lithuania of 3/06/2002 in Civil Case No. 3K-3-1006/2002. 
by one of the parents, who takes the child illegally into another country in order to unilaterally change the child's place of residence (child abduction). Resolution of such disputes involves specialised legal instruments, such as Council Regulation (EC) No. 2201/2003 of 27 November 2003, concerning jurisdiction and the recognition and enforcement of judgements in matrimonial matters and the matters of parental responsibility, repealing Regulation (EC) No. 1347/2000; The Hague Convention of 25 October 1980 on the Civil Aspects of International Child Abduction; European Convention for the Protection of Human Rights and Fundamental Freedoms, etc. For example, in the case Manic v. Lithuania, ${ }^{8}$ the plaintiff appealed to the court blaming Lithuanian institutions for inaction and disregard of his interests regarding enforcing the ruling of a British court on the contact regime with his underage son living in Lithuania with his mother. The court issued a statement that the corresponding authorities failed to enforce Art. 8 of the Convention and to protect the plaintiff's right to living with his family. The ECHR did not establish the contact regime, as that was the competence of national courts. A Lithuanian specialised court for that case $^{9}$ concluded that, in the absence of agreement between the parents regarding the contact regime, the court, which would be hearing the case, should take into consideration all the circumstances established by both British and Lithuanian competent authorities, because setting of the contact regime cannot be a goal in itself. Above all, it is aimed at the preservation and restoration of the bond between the child and the non-residential parent, when such bond has been weakened or lost. Regular and direct communication with the non-residential parent is the child's right, therefore the parents must to enforce this right, and the mother must provide conditions for the child to meet the father at the time convenient for the child. In another case, Z. J. v. Lithuania, ${ }^{10}$ the court first of all examined, whether the plaintiff's right of contact with children had been breached. The court took into consideration that Lithuanian courts had in principle accepted the plaintiff's right to live together with his children, and although they had provisionally declined his request, they acted in the best interests of the children in accordance with Art. 8 of the Convention, the national law and international instruments. No breach of Art. 8 of the Convention was detected in that case.

While considering the cases involving illegal abduction and/or retention of the child, the courts often impose provisional injunctions that oblige the non-residential parent to provide child maintenance. It should be noted, that quite often the parent who has brought the case of child abduction to the court, ${ }^{11}$ decides to ignore the ruling on provisional maintenance on the grounds that such a ruling contradicts the principle of international law, ex injuria jus non oritur, implying that unjust acts cannot create law. However, such practice should be considered as breaching the interests of the child. In fact, along with the provisional maintenance, a provisional contact

\footnotetext{
8 Judgment of European Court of Human Rights, Case No. 46600/11 Manic v. Lithuania.

9 Ruling of the Supreme Court of Lithuania of 8 May 2015 in Civil Case No. 3K-3-335-313/2015.

10 Judgment of European Court of Human Rights, Case No. 60092/12 Z. J. v. Lithuania.

11 Ruling of the Appellate Court of Lithuania of 15/06/2016 in Civil Case No. 2-1326-178/2016.
} 
regime should also be established in order to ensure the continuity of emotional connection with the child.

\section{Child maintenance}

The Constitution of the Republic of Lithuania (point 6, Art. 38) ${ }^{12}$ stipulates that parents are obliged to maintain their underage children until they reach majority. The Civil Code ${ }^{13}$ is more specific and states that parents are subject to maintenance obligation, whether or not they live in matrimony or separately, the marriage has been dissolved, children separated from their parents or parental authority restricted. According to the case law, child maintenance obligation is continuous and shall be fulfilled regularly, regardless of whether the child resides with the parent or separately, independently of the parental earnings and other income, and regardless of the presence of other close relatives, whom the child lives with. Each parent's duty to maintain their child is personal (intuitu personae), i.e. maintenance obligation can neither be transferred to other persons nor rejected. Failure to meet maintenance obligation, or inappropriate fulfilment thereof, cannot be justified by poor financial standing, another family relationship, departure, or any other reasons. The substance of parental obligations (including child care, parental authority and material maintenance) does not change for the non-residential parent, only different implementation conditions apply.

There are three ways to adjudge maintenance, according to the legal regulation thereof: in the form of regular contributions, by assigning a specific amount payable (a lump sum payment), or by adjudging certain property to the child (CC, art. 3.196). While deciding on the form of maintenance, the court must bear in mind that maintenance is designed to fulfil daily needs of the minors, such as food, clothes, housing, healthcare, studies, leisure activities, etc. ${ }^{14}$ Consequently, maintenance is necessary on the day-to-day basis, now and then, and not sometime in future. ${ }^{15}$

In the context of ever intensifying free movement of people within the EU, more and more often the amount of maintenance contribution is linked with the time dedicated by each of the parents to communication with and upbringing of the child. Even though some legal systems reject the link between child maintenance and the time spent with the child (the number of contact hours), in reality this link does exist beyond any doubt. ${ }^{16}$ Lithuania is among those countries that do not link the amount of maintenance contributions and the intensity of contacts with

12 Constitution of the Republic of Lithuania, 1993. Vilnius: LWUP edition.

13 Civil Code of the Republic of Lithuania. Official Gazette, 2000, No. 74.

14 Resolution of the Senate of the Supreme Court of Lithuania (SCL) No. 54 of 23/06/2005 "On the application of laws regulating parental maintenance obligations in court practice". Teismu praktika, 2005 m. No. 23 [Case Law, No. 23, 2005].

15 Ruling of the Supreme Court of Lithuania of 18/01/2010 in Civil Case No. 3K-3-49/2010.

16 Rešetar B. The Link Between Child Maintenance and Contact. In: Boele-Woelki K., Miles J. and Scherpe J. M. (eds.). The Future of Family Property in Europe, European Family Law Series, Vol. 29. Intersentia. Antwerp-Oxford-Portland, 2011, pp. 279-295. 
the child. Moreover, since 1 July 2001, ${ }^{17}$ Lithuania no longer applies a minimal or maximal (fixed) maintenance contribution, i.e., the legislators have chosen not to set a minimum threshold of child maintenance in the Civil Code, ${ }^{18}$ under the argument that the amount of maintenance should be proportional to the needs of underage children and wealth status of their parents (the "balance of needs and capabilities" approach), so as to ensure the necessary conditions for child's development.

The amount of maintenance contribution sufficient to ensure the necessary conditions for child's development is determined by the court in each particular case, taking into consideration specific circumstances. The case law of the Court of Cassation ${ }^{19}$ recognises that the guiding criterion in adjudging maintenance deemed necessary to meet the basic needs of a child is the amount of minimal monthly salary (equal to 350 euro as of 1 July 2016). This criterion, however, is only tentative and applied with consideration of the specific circumstances of each individual case. The Court of Cassation points out that the law does not specify any particular amount of child maintenance to be provided by the parents. Case law can only be used to standardise individual criteria deemed important for the establishment of the amount and form of maintenance, as well as for the application of the principle of proportionality to balancing the child needs, on the one hand, and wealth status and capabilities of parents, on the other hand. The fact that the amount of maintenance contributions for children living in Lithuania is usually established on the basis of the minimal salary does not mean that this is an established and recommended practice, because the amount of maintenance is set on case-by-case basis. ${ }^{20}$ Besides, when a court issues a ruling on maintenance, it must also ensure the enforceability of the ruling, i.e. the court cannot adjudge such child's maintenance that objectively exceeds the payment capacity allowed by the wealth status of the parents. ${ }^{21}$ In other words, both parents must contribute to child's maintenance in proportion with their corresponding levels of wealth. According to the principle of proportionality,

17 The Marriage and Family Code, which was abolished on 1 July 2001, had included the system of interest-bearing part of income, i.e. $1 / 4$ (or 25 per cent) of all received income for one child, 1/3 of all received income for two children, etc. Quod vide. Marriage and family Code of the Republic of Lithuania. Official Gazette, 1969, No. 21-186.

18 The provisions of the Civil Code, which came into force in 2001, in general, do not establish the minimum amount of maintenance and leaves it to the privilege of the court. Such position of the law is assessed as contradictious. Kudinavičiūtè-Michailovienè I., Végelienè J. Child maintenance: several topical theoretical and practical aspects// Jurisprudence: research paper/Mykolas Romeris University, Vilnius, 2012, No. 19(1), pp. 214-217; Sagatys G. The pre-harmonization area: a comparison of Lithuanian, Latvian and Estonian child maintenance laws. In: Boele-Woelki K., Miles J. and Scherpe J. M. (eds.). The Future of Family Property in Europe. European Family Law Series, Vol. 29. Intersentia. Antwerp-Oxford-Portland, 2011, p. 324; Kudinavičiūtè I. Civilinio kodekso normų, susijusių su šeimos narių teisių apsauga, igyvendinimo problemos [Realization of Civil Code Norms Related to the Defence of the Family Members' Rights]. Jurisprudencija: LTU mokslo darbai, 2002, T. 28(20).

19 Ruling of the Supreme Court of Lithuania of 26/04/2004 in Civil Case No. 3K-3-259/2004; Ruling of the Supreme Court of Lithuania of 10/11/2009 in Civil Case No. 3K-3-495/2009.

20 Ruling of the Supreme Court of Lithuania of 3/02/2016 in Civil Case No. 3K-3-16-706/20166.

21 Ruling of the Supreme Court of Lithuania of 8/02/2016 in Civil Case No. 3K-3-37/2010. 
the parent receiving higher income must assume a bigger share of the expenses necessary for the maintenance of the child. ${ }^{22}$

When a child is moved to live abroad by mutual consent of both parents, they both are deemed to have consciously assumed the possibly greater child maintenance burden, which depends on the living standards in the foreign state chosen as the new place of residence. However, if one of the parents does not approve the foreign residence of the child, the other parent, on whose incentive the child is moving abroad, shall undertake the partial increase of expenses related to the child's needs. ${ }^{23}$ The prevailing opinion in the Lithuanian case law is such that divorce or separation of parents should not lead to a substantial deterioration in meeting the child's needs. If those needs were fulfilled while the parents were living together, the child should be provided with maximum possibilities to maintain comparable living standards and development conditions with the parents living separately.

It should be noted that, according to the Lithuanian law, poor circumstances of the parents shall not provide grounds for their complete exemption from the maintenance obligation, i.e. poor circumstances of the parents may influence only the amount of maintenance contribution, but shall not repeal the obligation as such. However, certain states, e.g. France ${ }^{24}$ or Germany, provide for a possibility of exemption from the parental maintenance obligation due to the poor financial standing of the parents.

Several legal instruments are available within the EU for the facilitation of proper enforcement of maintenance obligations and streamlining of the maintenance cases. Procedures related to maintenance obligations originating from family relations, parenthood, matrimony, or kinship are set in the Council Regulation (EC) No 4/2009 of 18 December 2008 on jurisdiction, applicable law, recognition and enforcement of decisions and cooperation in matters relating to maintenance obligations. The Regulation foresees different regulatory procedures for the recognition, applicability and enforcement of court rulings related to maintenance obligations, dependent on whether the court ruling was issued in a Member State, which is a party to the Hague Protocol of 23 November 2007 on the Law Applicable to Maintenance Obligations or not. Thus, cooperation between corresponding central authorities of different states contributes to a more efficient cross-border enforcement of maintenance obligations..$^{25}$

22 Šeimos bylų nagrinejjimo ir teismo sprendimų vykdymo ypatumai. Mokslo studija. Vilnius: MRU, 2013, pp. 80-87 Family Cases: Adjudication and Enforcement. Scientific study. Tamošiūniené E., Kudinavičiūtè-Michailovienė I. (eds.). Vilnius: Mykolas Romeris University, 2013.

23 Ruling of the Supreme Court of Lithuania of 8/04/2015 in Civil Case No. 3K-3-195-915/2015.

24 Ruling of Vilnius District Court of 9/04/2009 in Civil Case No. 2A-156-464/2009.

25 Ruling of the Appellate Court of Lithuania of 20/07/2015 in Civil Case No. 2T-74-381/2015. 


\section{Sociological aspect}

While analysing the state's role in legal enforcement of parental responsibilities, it is important to assess how this system is seen by parents living separately from their children, to understand their subjective perception of fairness of the corresponding court rulings, and their reasoning why the rulings were against them. The results of sociological survey conducted in Lithuania in the period from March to May of 2016 presented below attempt to provide answers to these questions. The survey involved 1500 male parents living separately from their underage children. The subsequent analysis covers only the subsample of 890 fathers, who had their divorce settled in a court and subsequently were subject to court decisions and could evaluate them. The survey ${ }^{26}$ suggests that Lithuanian men broadly accept most of the court decisions in their divorce cases as fair. As many as $80 \%$ of male parents agreed that the court decision regarding the place of residence of the child/children following the divorce was fair, and a similar percentage were positive about the established rules regarding contacts with the child, participation in his/her upbringing and addressing the child's needs. Also, $60 \%$ of them accepted as fair the rulings regarding the amount of alimony, allocation of debts (if any), assets or savings (if any), and maintenance to the ex-spouse (if any). Thus, in the context of generally positive attitude towards the court rulings related to divorce, there is an obvious trend that the rulings on child's place of residence and communication between the father and the child are seen in a positive light more often than the rulings covering financial and material aspects.

Analysis of the subjective perception of fairness of the rulings in divorce cases was focused on the reasons specified by the male parents in explanation of allegedly unfair rulings against them. Out of the analysed sample, $27 \%$ indicated that at least one aspect in the court ruling was unfair with regard to them. The most common reason specified by these men was related to the performance of the lawyers: $62 \%$ of the respondents held an opinion that their spouse's lawyer was able to better defend her interests, while $42 \%$ indicated that they could not hire a good lawyer. Another group of reasons was linked with the performance of judges and other institutions involved in the proceedings. As many as $50 \%$ of men in this category indicated the gender of the judge as the reason for an unfair judgement and were convinced that female judges were biased in favour of the mothers, while $40 \%$ explained the unfair rulings as resulting from the conclusions of the Child Rights Protection Service that were against the father. Conflicting and unethical relationship between the former spouses was another popular explanation. A half of the men felt that their ex-partners had vilified them, 1/3 felt that former spouses had biased their children against them, all that contributing to an unfair ruling.

26 Paternity after divorce in Lithuania, 2016. This research was funded by a grant (No. GER-010/2015) from the Research Council of Lithuania. 


\section{Conclusions}

1. According to Constitution of Lithuania, development of a child as an integral personality requires support and care of both parents. The child has to be sure that he/she is equally important to both parents, and that each of them is accessible when needed most. The parents should share a common goal: to guarantee their child a secure connection with both of them and to ensure the upkeep of their child, as well.

2. A child whose parents are separated shall have a right to have a constant and direct contact with both parents irrespective of their residence. The father or the mother with whom the child resides may not interfere with the other parent's contacts with the child or involvement in the child's education. According to the last divorce cases contact regime with children should be necessarily provided by the Court even if the parents do not apply for it.

3. Lithuania is among those countries that do not link the amount of maintenance contributions and the intensity of contacts with the child. Under the legal regulation the amount of maintenance should be proportional to the needs of underage children and wealth status of their parents - the "balance of needs and capabilities" approach.

3. Sociological survey of male parents suggests that their overall attitude towards the rulings issued by Lithuanian courts in divorce cases is more positive than negative. More positive evaluations were given to the rulings on child's place of residence and communication between the father and the child than to those covering financial and material aspects (including child maintenance). The perceived unfairness is usually linked with poor legal representation during the legal proceedings, although another commonly suggested reason is a biased attitude of female judges in divorce cases in favour of the mothers.

\section{BIBLIOGRAPHY}

\section{Literature}

1. Boele-Woelki K. and others. Principles of European Family Law regarding Parental Responsibilities. Intersentia, 2007.

2. Kudinavičiūtè-Michailovienė I., Vègelienė J. Child maintenance: several topical theoretical and practical aspects. Jurisprudence: research paper, Mykolas Romeris University, Vilnius, 2012, No. 19(1), pp. 214-217.

3. Kudinavičiūtė I. Civilinio kodekso normų, susijusių su šeimos narių teisių apsauga, igyvendinimo problemos [Realization of Civil Code Norms Related with the Defence of the Family Members' Rights]. Jurisprudencija: LTU mokslo darbai, 2002, T. 28(20).

4. Maslauskaitė A., Stankūnienè. Šeima abipus sienų: Lietuvos transnacionalinės šeimos genezė, funkcijos, raidos perspektyvos [Family Across Frontiers: Genesis, functions and development prospective of trans-national families in Lithuania]. Vilnius: International Organization for Migration, Institute of Social Research, 2007. 


\section{Legislative acts}

1. Civil Code of the Republic of Lithuania Official Gazette, 2000, No. 74.

2. Constitution of the Republic of Lithuania, 1993. Vilnius: LWUP edition.

3. Council Regulation (EC) No. 4/2009 of 18 December 2008 on jurisdiction, applicable law, recognition and enforcement of decisions and cooperation in matters relating to maintenance obligations. Available at http://eur-lex.europa.eu/legal-content/EN/ TXT/?uri=URISERV\%3Aj10024 [last viewed August 22, 2016].

4. Marriage and family Code of the Republic of Lithuania. Official Gazette, 1969, No. 21-186.

5. Rešetar B. The Link Between Child Maintenance and Contact. In: Boele-Woelki K., Miles J. and Scherpe J. M. (eds.). The Future of Family Property in Europe, European Family Law Series, Vol. 29. Intersentia. Antwerp-Oxford-Portland, 2011, pp. 279-295.

6. Sagatys G. The pre-harmonization area: a comparison of Lithuanian, Latvian and Estonian child maintenance laws. In: Boele-Woelki K., Miles J. and Scherpe J. M. (eds.). The Future of Family Property in Europe (European Family Law Series, Vol. 29). Intersentia. AntwerpOxford-Portland, 2011, p. 324.

7. Šeimos bylų nagrinejjimo ir teismo sprendimų vykdymo ypatumai. Mokslo studija. Vilnius: MRU, 2013, pp. 80-87. Family Cases: Adjudication and Enforcement. Scientific study. Edited by E. Tamošiūnienè, I. Kudinavičiūtè-Michailovienė. Vilnius: Mykolas Romeris University, 2013.

\section{Legal practice}

1. Judgment of European Court of Human Rights, Case No. 60092/12 Z. J. v. Lithuania.

2. Judgment of European Court of Human Rights, Case No. 46600/11 Manic v. Lithuania.

3. Resolution of the Senate of the Supreme Court of Lithuania (SCL) No. 54 of 23/06/2005 "On the application of laws regulating parental maintenance obligations in court practice". Teismų praktika, 2005 m. No. 23 [Case Law, No. 23, 2005].

4. Ruling of the Supreme Court of Lithuania of 18/01/2010 in Civil Case No. 3K-3-49/2010.

5. Ruling of the Supreme Court of Lithuania of 26/04/2004 in Civil Case No. 3K-3-259/2004.

6. Ruling of the Supreme Court of Lithuania of 10/11/2009 in Civil Case No. 3K-3-495/2009.

7. Ruling of the Supreme Court of Lithuania of 3/02/2016 in Civil Case No. 3K-3-16-706/2016.

8. Ruling of the Supreme Court of Lithuania of 8/02/2016 in Civil Case No. 3K-3-37/2010.

9. Ruling of the Supreme Court of Lithuania of 8/04/2015 in Civil Case No. 3K-3-195-915/2015.

10. Ruling of the Supreme Court of Lithuania of 8/05/2005 in Civil Case No. 3K-3-30/2005.

11. Ruling of the Supreme Court of Lithuania of 3/06/2002 in Civil Case No. 3K-3-1006/2002.

12. Ruling of the Supreme Court of Lithuania of 8 May 2015 in Civil Case No. 3K-3-335-313/2015.

13. Ruling of Vilnius District Court of 9/04/2009 in Civil Case No. 2A-156-464/2009.

14. Ruling of the Appellate Court of Lithuania of 20/07/2015 in Civil Case No. 2T-74-381/2015.

15. Ruling of the Appellate Court of Lithuania of 15/06/2016 in Civil Case No. 2-1326-178/2016.

\section{Other sources}

1. European Migration Network. Available at http://123.emn.lt/lt/bendros-tendencijos/ migracija-10-metu-apzvalga [last viewed August 22, 2016]. 


\author{
Aleksei Kelli, PhD \\ University of Tartu, Estonia
}

Kadri Vider, MA

University of Tartu, Estonia

Heiki Pisuke ${ }^{1}, \mathrm{PhD}$

Council of the European Union, Belgium

Triin Siil, PhD candidate

University of Tartu, Estonia

\title{
CONSTITUTIONAL VALUES AS A BASIS FOR THE LIMITATION OF COPYRIGHT WITHIN THE CONTEXT OF DIGITALISATION OF THE ESTONIAN LANGUAGE
}

\begin{abstract}
Summary
The article analyses the digitalisation of the Estonian language within the constitutional framework. The authors focus on the interaction between copyright as a constitutional right and constitutional values protecting language. The central research question of the article is: can the author's exclusive rights be restricted by constitutional values? The authors suggest that the principle of protection of the Estonian language enshrined in the Estonian Constitution has an impact on the interpretation and implementation of copyright law. The Estonian Copyright Act has to be interpreted and implemented so as to allow the digitalisation of the Estonian language.
\end{abstract}

Keywords: digitalisation of a language, constitutional values, copyright.

\section{Introduction}

Digital technologies have created new opportunities for language research and development of language-based products and services (language technologies). The article focuses on the digitalisation of small languages, since they deserve special attention. Without digitalisation, small languages cannot survive. The use of modern technology to digitise languages helps to maintain and revitalize them. The main problem is that language technologies based on small languages (e.g. Estonian, Irish, Latvian and Lithuanian) do not have a commercial potential comparable to technologies exploiting big languages (e.g. English, German, French and Spanish). ${ }^{2}$

The views expressed in this article are purely those of the authors and may not in any circumstances be regarded as stating an official position of the Council of the European Union or other EU institutions.

2 See Liin K., Muischnek K., Müürisep K., Vider K. Eesti keel digiajastul (The Estonian language in the digital age). Available at http://www.meta-net.eu/whitepapers/e-book/estonian.pdf [last viewed August 28, 2016]. 
While companies and institutions could get a substantial return on their investments in language technologies designed for big languages, this is not the case for small languages. The market for them is simply too small. Their development can be adversely affected by different legal requirements, such as the need to acquire copyright licences covering material used for language technologies (even without the obligation to pay).

The digitalisation of languages is directly connected with national language policies. It is crucial to work on policies and legal requirements supporting the creation of language technologies for small languages. According to the UNESCO language vitality methodology, Estonian does not belong to the some 3000 "endangered languages" worldwide. ${ }^{3}$ However, pursuant to a classification used in public documents and scientific research Estonian is deemed a "small language". Although Estonian is the official language of a nation state, it has some features characteristic of a "language at risk" due to several political, economic and social reasons. Therefore, government policies on the protection of the Estonian language are of utmost importance.

In order to address the digitalisation of small languages in the constitutional framework, ${ }^{4}$ the authors put forward the following hypotheses:

1. Intellectual property is an important legal instrument to protect and enhance small languages;

2. The digitalisation of small languages should be regarded in the context of constitutional values such as the preservation of a language. Intellectual property rights cannot take precedence over a need to digitise small languages. Without digitalisation small languages cannot survive.

3. The current regulatory framework in the EU does not support digital language research and the development of language technologies. The regulation lacks legal clarity and shifts risks, high administrative and financial burdens onto organisations and researchers working in this field. This has a particularly adverse impact on small languages which require preferential treatment since their digitalisation is driven by public interests rather than business considerations.

The aim of the article is to answer the question whether the author's exclusive rights can be restricted by constitutional values to allow the digitalisation of the Estonian language.

3 See UNESCO. Atlas of the World's Languages in Danger. Available at http://unesdoc.unesco.org/ images/0019/001924/192416e.pdf [last viewed June 9, 2016].

4 The article draws on and continues the previous research conducted in the field. See Kelli A., Tavast A., Pisuke H. Copyright and Constitutional Aspects of Digital Language Resources: The Estonian Approach. Juridica International, 2012, No. 19, pp. 40-48. Available at http://juridicainternational. eu/public/pdf/ji_2012_1_40.pdf [last viewed August 28, 2016]; Tavast A., Pisuke H., Kelli A. Õiguslikud väljakutsed ja võimalikud lahendused keeleressursside arendamisel (Legal challenges and possible solutions in developing language resources). Eesti Rakenduslingvistika Ühingu aastaraamat, 2013, No. 9, pp. 317-332. Available at http://www.rakenduslingvistika.ee/ajakirjad/ index.php/aastaraamat/article/view/228/0 [last viewed August 28, 2016]. 
Since challenges relating to personal data protection and the development of contractual models for the dissemination of digitised language data have been addressed previously ${ }^{5}$ and due to the focus of this paper, they have been omitted from the scope of this article.

The article follows traditional legal research methods. The digitalisation of the Estonian language is used as a benchmark since the authors have worked with legal, technical and policy issues relating to this process at national and international levels (e.g. CLARIN ${ }^{6}$ ). The previous experience has given the authors deep and practical insights into the whole digitalisation process from different perspectives.

The article is organised into two main sections. In the first section, the authors analyse the digitalisation of a language from the technological and legal perspectives. Without understanding the technical nature of digitalisation (what is done during the process) it is hard to analyse its legal implications. The second section places digitalisation into the constitutional framework.

\section{Technological and legal nature of digitalisation}

Language by its nature is a phenomenon specific to each human being. It gives human beings a chance to express themselves in a natural and original way. In this process, human beings "produce" linguistic material as facts that can be saved and restored either visually as text or audibly as recorded oral speech. All this material was an important source for linguistic research in the non-digital, analogous and printed era. In the digital era, this material carries even more weight.

In this article, language digitalisation covers the following aspects (see Figure 1. Language digitalisation):

1) copying text and speech and its conversion into machine-readable form (digitalisation of language data);

For further discussion, see Kelli A., Vider K., Lindén K. The Regulatory and Contractual Framework as an Integral Part of the CLARIN Infrastructure. Available at www.ep.liu.se/ecp/article. asp?issue $=123 \&$ article $=002$ [last viewed June 9, 2016]; Kelli A., Vider K., Pisuke H., Lindén K. Digitaalsete keeleressursside loomist ja kasutamist määrav õiguslik raamistik Eestis ja selle ühildumine CLARIN-i infrastruktuuriga (Regulatory Framework Determining the Development and Utilization of Digital Language Resources and Technologies in Estonia and its Compatibility with CLARIN Infrastructure). Eesti Rakenduslingvistika Ühingu aastaraamat, 2016, No. 12, pp. 81-98. Available at http://rakenduslingvistika.ee/ajakirjad/index.php/aastaraamat/article/ view/ERYa12.05 [viewed 2016. 16 August]; Vider K., Pisuke H., Mõtsküla P. P., Tuulik T., Kelli A. Keeleressursside litsentsimise õiguslikke küsimusi (Legal considerations in licensing language resources). Eesti Rakenduslingvistika Ühingu aastaraamat, 2013, No. 9, pp. 333-347. Available at http://www.rakenduslingvistika.ee/ajakirjad/index.php/aastaraamat/article/view/ERYa9.21 [last viewed August 16, 2016]; Jents L., Kelli, A. Legal Aspects of Processing Personal Data in Development and Use of Digital Language Resources: the Estonian Perspective. Jurisprudence, 2014, No. 21(1), pp. 164-18. Available at https://www.mruni.eu/upload/iblock/fdd/JUR-14-211-08.pdf [last viewed August 16, 2016].

6 CLARIN (Common Language Resources and Technology Infrastructure). Additional information available at https://www.clarin.eu/content/clarin-in-a-nutshell [last viewed August 16, 2016]. 
2) supplementing language data with meta-data and annotations (the development of language resources). In this mostly technical process written text or recorded speech is analysed by computer programmes for natural language processing (NLP) and different kind of (syntactical, lexical, semantic etc.) annotation marks are added to the data by programmes. Machine-readable data turns into enriched annotated data and forms reusable digital language resource. Programmes for text and data mining $(\mathrm{TDM})^{7}$ are also implemented in this phase to discover valuable new information about content;

3) Language resources are used to develop language technologies.

Figure 1. Language digitalisation

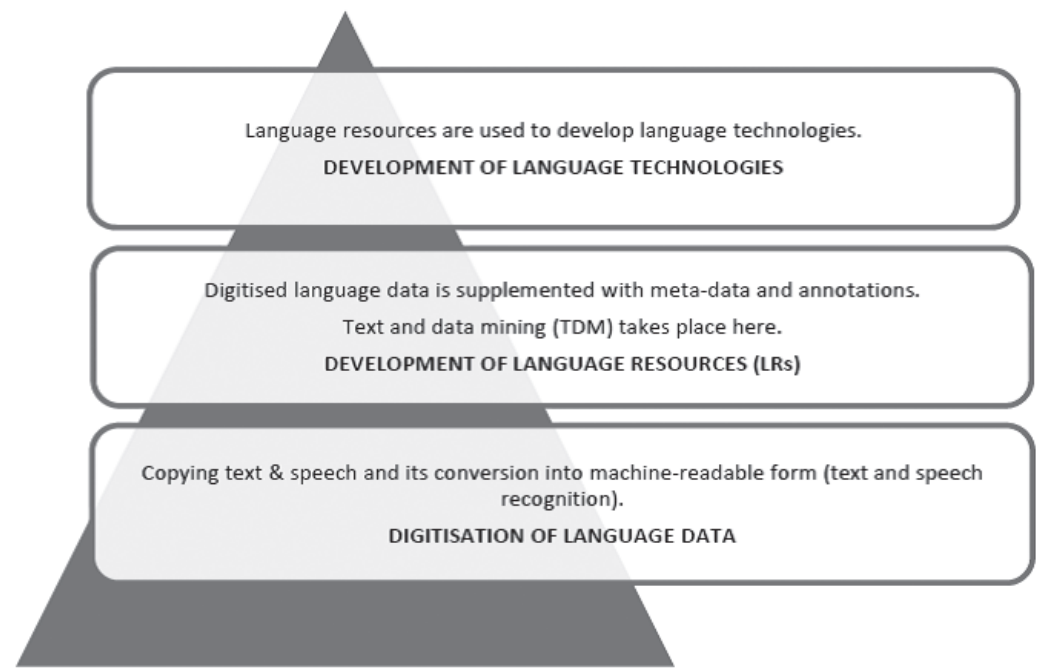

Text and data mining (TDM) is described in the impact assessment on the modernisation of EU copyright rules as "automated analysis of large volumes of text and data. Depending on the context, other terms used to describe the same techniques are business intelligence, information analysis or text and data analytics". European Commission. Commission staff working document impact assessment on the modernisation of EU copyright rules accompanying the document. Proposal for a Directive of the European Parliament and of the Council on copyright in the Digital Single Market and Proposal for a Regulation of the European Parliament and of the Council laying down rules on the exercise of copyright and related rights applicable to certain online transmissions of broadcasting organisations and retransmissions of television and radio programmes. Brussels, 14.9.2016. SWD(2016) 301 final. PART 3/3. ANNEX 11B - TECHNICAL ASPECTS OF TDM, p. 158. Available at https://ec.europa.eu/digital-single-market/en/news/impact-assessmentmodernisation-eu-copyright-rules [last viewed September 29, 2016]. Intellectual Property Office of the UK explains in its policy document TDM as follows: "Text and data mining is the use of automated analytical techniques to analyse text and data for patterns, trends and other useful information. Text and data mining usually requires copying of the work to be analysed". Intellectual Property Office. Exceptions to copyright: Research. Available at https://www.gov.uk/ government/uploads/system/uploads/attachment_data/file/375954/Research.pdf [last viewed August 28, 2016]. 
Language digitalisation has given rise to several legal issues. Digitalisation of language data as the first step in the process entails copying written and/or oral material which is usually protected by copyright and related rights (the performer's rights whose oral presentation is used). ${ }^{8}$ The next step is the transformation of language data into language resources (LRs). Basically, it means the creation of a derivative work based on language data (annotations and metadata are added to the copied texts).

The development of LRs is not subject to any legal restrictions arising from copyright law if the used material is not copyrighted (e.g. copyright has expired; non-protectable legal texts are used; etc.). Language resources, however, cannot be developed relying solely on this kind of historic and official material. The use of copyrighted material is needed for contemporary language analyses and language technologies. Therefore, the development and use of LRs has to fit within the framework of IP law. The existence of language resources is often conditio sine qua non for language technologies. Language technologies themselves usually constitute copyright-protected software and their creation does not pose any exceptional copyright-related challenges. For this reason, the analysis below concentrates on language resources.

Language resources themselves are copyright-protected original collections of written and oral material. Since the creation of LRs often requires a substantial investment, sui generis database protection ${ }^{9}$ is applicable, as well.

As a result, language resources are covered with two tiers of rights: $\left.{ }^{10} 1\right)$ the rights covering LRs as a database (the rights of persons who developed resources); 2) the rights covering the material used for the development of LRs (the core of which consists of the rights of copyright and related rights owners, whose works and objects of related rights are used in LRs; the data subject's rights, whose personal data is used in LRs (see Figure 2. Two tiers of rights covering language resources).

In the following text the term "copyright" also covers related rights.

9 See Database Directive Art. 7. Directive 96/9/EC of the European Parliament and of the Council of 11 March 1996 on the legal protection of databases. Official Journal L 077, 27/03/1996 pp. 0020-0028.

10 Kelli A., Vider K., Pisuke H., Lindén K. Digitaalsete keeleressursside loomist ja kasutamist määrav öiguslik raamistik Eestis ja selle ühildumine CLARIN-i infrastruktuuriga (Regulatory Framework Determining the Development and Utilization of Digital Language Resources and Technologies in Estonia and its Compatibility with CLARIN Infrastructure). Eesti Rakenduslingvistika Ühingu aastaraamat, 2016, No. 12, pp. 81-98. Available at http://rakenduslingvistika.ee/ajakirjad/index. php/aastaraamat/article/view/ERYa12.05 [last viewed August 16, 2016]. 
Figure 2. Two tiers of rights covering language resources

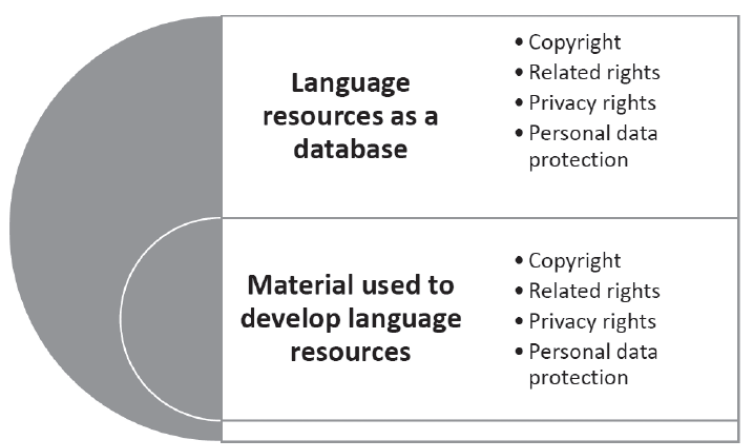

Two main models for the development of LRs could be identified, as follows: 1) the contractual model based on the consent of copyright holders and 2) the exception model, where the use of original material is based on the restrictions of copyright owner's exclusive rights. ${ }^{11}$ It is also possible to develop mixed models (e.g. some uses of copyright material require consent, some do not). The extended collective licensing scheme could also be employed in practical implementation of these models. ${ }^{12}$

Since the development of LRs entails changing the material (e.g. adding annotations and metadata), the issues relating to the author's moral rights are bound to arise. ${ }^{13}$

\section{Conceptualisation of language digitalisation within the constitutional framework}

Digitalisation of a language requires favourable legal conditions for the development and use of language resources. At this point, the constitutional framework influences the implementation of copyright law. Copyright law itself protects several

11 For further discussion, see Kelli A., Vider K., Lindén K. The Regulatory and Contractual Framework as an Integral Part of the CLARIN Infrastructure. Available at www.ep.liu.se/ecp/ article.asp?issue $=123 \&$ article $=002$ [last viewed June 9, 2016] .

12 For further discussion on the extended collective licensing, see Vasamäe E. Autoriõiguste ja autoriõigusega kaasnevate õiguste jätkusuutlik kollektiivne teostamine (Sustainable collective management of copyright and related rights). Doctoral thesis (supervisor Professor H. Pisuke) University of Tartu, 2014.

13 On moral rights, see Ricketson S., Ginsburg J. C. International Copyright and Neighbouring Rights: The Berne Convention and Beyond. Second Edition. Volume I. Oxford University Press, 2006; von Lewinski S. International Copyright Law and Policy. Oxford University Press, 2008; Walter M. M., von Lewinski S. European Copyright Law: a Commentary. Oxford University Press, 2010; Kelli A., Hoffmann T., Pisuke H., Kull I., Jents L., Ginter C. The Exercise of Moral Rights by Non-Authors. Journal of the University of Latvia "Law", 2014, 6, pp. 108-125. Available at http://www.lu.lv/ fileadmin/user_upload/lu_portal/apgads/PDF/Juristu-zurn_6.pdf [last viewed September 29, 2016]. 
fundamental rights (e.g. the right to property, the right to privacy, the right to integrity of the person, etc.) at international ${ }^{14}$ and national levels. ${ }^{15}$ These rights do not exist in isolation but interact with other rights (e.g. the right to culture and education, the linguistic or language rights) and constitutional values. The authors argue that there is a conflict between the protection of the right to property (the copyright holder's fundamental right in material used for LRs) and safeguarding the Estonian language as a constitutional value enshrined in the preamble of the Estonian Constitution $^{16}$ and. therefore. defined as one of the main goals of the Republic of Estonia.

On 21 July 2007, a significant amendment was made to the preamble of the Estonian Constitution: "With unwavering faith and a steadfast will to strengthen and develop the state ... which must guarantee the preservation of the Estonian people, the Estonian language [emphasis added] and the Estonian culture through the ages". ${ }^{17}$ Professor Raul Narits states that "In view of the text of the Constitution, values are predominant in its preamble. The very universal values contained in the preamble "infiltrate" into the other provisions of the Constitution, thus moulding the spirit of the Constitution". ${ }^{18}$ The comments on the Estonian Constitution explain that "the inclusion of the Estonian language in the preamble of the Constitution together with the other fundamental principles constitutes the acknowledgement of the Estonian language as a core of the nation. We cannot speak of the Estonian culture without the Estonian language". ${ }^{19}$

According to the accompanying explanatory memorandum to the respective draft legislation, the purpose of this amendment was to state expressly that the Estonian language is protected by the Constitution and thereby provide stronger symbolic

14 See Geiger C. Research Handbook on Human Rights and Intellectual Property Research Handbooks in Intellectual Property series. Edward Elgar, 2015.

15 See Ernits M., Roosma P., Kelli A. Commentaries on $\$ 32$ of the Constitution of the Republic of Estonia and Kelli A., Pisuke H. Commentaries on $\$ 39$ of the Constitution of the Republic of Estonia. In: Eesti Vabariigi põhiseadus. Kommenteeritud väljaanne. Kolmas, täiendatud väljaanne (Constitution of the Republic of Estonia, Commented Edition, Third Edition), edited by a panel led by Madise Ü. Tallinn: Juura, Õigusteabe AS 2012. Available at http://www.pohiseadus.ee/public/ EVPS_kommeteeritud_valjaanne_2012.pdf [last viewed August 21, 2016].

16 Constitution of the Republic of Estonia. Available at https://www.riigiteataja.ee/en/ eli/521052015001/consolide [last viewed June 9, 2016].

17 This approach is not unique and can also be found in the Latvian and Lithuanian Constitutions. See Constitution of the Republic of Latvia. Translation available at http://www.saeima.lv/en/ legislation/constitution [last viewed June 9, 2016]; Constitution of the Republic of Lithuania. Available at http://www3.lrs.lt/home/Konstitucija/Constitution.htm [last viewed June 9, 2016].

18 Nartis R. The Republic of Estonia Constitution on the Concept and Value of Law. Juridica International, 2002, No. 7, p. 13. Available at http://juridicainternational.eu/public/pdf/ji_2002_ 1_10.pdf [last viewed August 28, 2016].

19 Narits R., Schneider H. Commentaries on preamble. In: Eesti Vabariigi põhiseadus. Kommenteeritud väljaanne. Kolmas, täiendatud väljaanne (Constitution of the Republic of Estonia, Commented Edition, Third Edition), edited by a panel led by Madise Ü. Tallinn: Juura, Õigusteabe AS 2012, p. 38. Available at http://www.pohiseadus.ee/public/EVPS_kommeteeritud_valjaanne_2012.pdf [last viewed August 21, 2016]. 
as well as legal guarantees for preserving the Estonian language. ${ }^{20}$ Nevertheless, the legal implications of this alteration in the preamble are a matter of discussion. The main question that arises here is whether the preservation of the Estonian language is a constitutional right, obligation, principle or goal. Each designation presumes a different conceptualisation of the preservation of the Estonian language in the framework of the Estonian Constitution. For example, if treated as a fundamental right, it can be evaluated against other fundamental rights but as a fundamental principle it serves as a justification and criteria upon implementing and interpreting the Constitution.

Researchers of Estonia's constitutional law have pointed out that the preservation of the Estonian people, language and culture is sometimes treated as a separate fundamental principle of the Estonian Constitution. ${ }^{21}$ On other occasions, it is addressed as a precondition to the preservation of the Estonian culture ${ }^{22}$ and referred to as the main task of the country as such. R. Alexy sees the lingual selfpreservation and identity as part of the Estonian identity. ${ }^{23}$ All the aforementioned cases treat preservation of the Estonian language not as a means to an end but an end in itself - it is the primary purpose that all other constitutional rights, obligations, principles and goals are designed to serve. This conclusion is further supported by the position on the purpose to preserve the Estonian language in the preamble of the Constitution. Legal researchers in Estonia suggest that the preamble has legal effect and it constitutes the all-embracing core of the entire Estonian Constitution. ${ }^{24}$ Having concluded that the preservation of the Estonian language is one of the key purposes laid out in the Estonian Constitution, the next question is whether such high importance in the Estonian constitutional framework justifies the limitation of other fundamental rights such as the author's rights in respect of his or her work. The author's rights can also be seen as sub-rights to the right to protection of property. ${ }^{25}$

20 Seletuskiri Eesti Vabariigi põhiseaduse muutmise seaduse eelnõu 974 SE juurde (Explanatory memorandum to the Constitution of the Republic of Estonia daft Amendment Act 974 SE). Available at http://www.riigikogu.ee/tegevus/eelnoud/eelnou/cf9123d5-108f-db00-8a4a2473d2abe91d/Eesti\%20Vabariigi\%20p\%C3\%B5hiseaduse\%20muutmise\%20seadus/ [last viewed August 25, 2016].

21 Ernits M. Põhiseaduse aluspõhimõtted (The Fundamental Principles of the Constitution). Riigikogu Toimetised, 2011, No. 24, pp. 95-104. Available at http://rito.riigikogu.ee/eelmised-numbrid/nr24/pohiseaduse-aluspohimotted/ [last viewed August 25, 2016].

22 Narits R., Schneider H. Commentaries on preamble. In: Eesti Vabariigi põhiseadus. Kommenteeritud väljaanne. Kolmas, täiendatud väljaanne (Constitution of the Republic of Estonia, Commented Edition, Third Edition), edited by a panel led by Madise Ü. Tallinn: Juura, Õigusteabe AS 2012, p. 38, 41. Available at http://www.pohiseadus.ee/public/EVPS kommeteeritud valjaanne 2012. pdf [last viewed August 21, 2016].

23 Alexy R. Põhiõigused Eesti põhiseaduses (Fundamental Rights in the Estonian Constitution). Juridica, 2001, Special issue, (section 7.2.1.3), pp. 5-96.

24 Narits R., Schneider H. Commentaries on preamble. In: Eesti Vabariigi põhiseadus. Kommenteeritud väljaanne. Kolmas, täiendatud väljaanne (Constitution of the Republic of Estonia, Commented Edition, Third Edition), edited by a panel led by Madise Ü. Tallinn: Juura, Õigusteabe AS 2012, p. 40. Available at http://www.pohiseadus.ee/public/EVPS_kommeteeritud_valjaanne_2012.pdf [last viewed August 21, 2016].

25 Alexy R. Põhiõigused Eesti põhiseaduses (Fundamental Rights in the Estonian Constitution). Juridica, 2001, Special issue, pp. 5-96. 
When considering the restriction of the author's rights for the purpose of developing language technologies for the Estonian language, one has to conduct a proportionality analysis to find out if a limitation of the given fundamental right would be in line with the Estonian Constitution. We argue that such limitation is appropriate because otherwise it is quite likely that copyright owners can obstruct building an adequate pool of language data (language resources) to be used for creating language technologies. It is also necessary because clearing of the rights is a considerable cost for the developers of language resources who are mostly universities or public research institutes and thus mainly draw on public resources.

Although the constitutional framework forms the foundation of a legal order, the specific norms affecting digitalisation are set forth in copyright law. Copyright law itself embodies international, the EU and national norms. Within this context, the EU law plays a relevant role.

The importance of the digitalisation of languages is acknowledged at the EU level. The urgency to develop conditions for text and data mining (TDM) is emphasised in several EU documents. ${ }^{26}$ In a review of InfoSoc Directive ${ }^{27}$ prepared by the European Parliamentary Research Service (EPRS), it is stressed that "the absence of legal certainty to support the development of text and data mining is a key gap in urgent need of addressing" ${ }^{28}$ It should be mentioned that text and data mining ${ }^{29}$ is not possible without language resources.

It is a vital interest of Estonia, and probably some other countries with a similar language situation, to have a mandatory exception on TDM in the EU legislation. At present, Article 5 "Exceptions and limitations" of the Directive on the harmonisation of certain aspects of copyright and related rights in the information society ${ }^{30}$ does not contain such an exception. ${ }^{31}$ Within the concept of a Digital Single Market, the work

26 For instance, see Communication from the Commission to the European Parliament, the Council, the European Economic and Social Committee and the Committee of the Regions. Towards a modern, more European copyright framework. Brussels, 9.12.2015. $\operatorname{COM(2015)~} 626$ final. Available at http://eur-lex.europa.eu/legal-content/EN/TXT/HTML/?uri=CELEX:52015DC06 26\&rid=1 [last viewed June 9, 2016].

27 Directive 2001/29/EC of the European Parliament and of the Council of 22 May 2001 on the harmonisation of certain aspects of copyright and related rights in the information society. Official Journal L 167, 22/06/2001 P. 0010 - 0019.

28 European Parliamentary Research Service (2015). Review of the EU copyright framework. European Implementation Assessment, p. 20. Available at http://www.europarl.europa.eu/RegData/etudes/ STUD/2015/558762/EPRS_STU\%282015\%29558762_EN.pdf [last viewed June 9, 2016].

29 It is suggested to use the concept of "data analysis" instead of the concept of "text and data mining" to cover all types of content such as text, images, videos, etc. See Triaille J.-P., de Meeûs d’Argenteuil J., de Francquen A. Study on the legal framework of text and data mining (TDM). Available at http:// ec.europa.eu/internal_market/copyright/docs/studies/1403_study2_en.pdf [last viewed June 9, 2016].

30 Directive 2001/29/EC of the European Parliament and of the Council of 22 May 2001 on the harmonisation of certain aspects of copyright and related rights in the information society. Official Journal L 167, 22/06/2001 P. 0010 - 0019.

31 The approach of some experts suggests that the fair use type of copyright exception could have a favourable impact on TDM. - See Filippov S., Hofheinz P. Text and Data Mining for Research and Innovation. Available at http://www.lisboncouncil.net/news-a-events/700-new-policy-brief-textand-data-mining-for-research-and-innovation-.html [last viewed September 29, 2016]. 
undertaken by the Commission aims to adjust and elaborate the list of exceptions. ${ }^{32}$ The adoption of the proposal on copyright in the Digital Single Market ${ }^{33}$ (Proposal for a Directive on copyright) is a positive development for language digitalisation. It defines TDM, as follows: "any automated analytical technique aiming to analyse text and data in digital form in order to generate information such as patterns, trends and correlations" (Article 2(2)). The directive obliges Member States to provide for an exception for reproductions and extractions made by research organisations in order to carry out text and data mining of works or other subject matter to which they have lawful access for the purposes of scientific research (Article 3(1)). In order to avoid contractual overridibility, it is provided that any contractual provision contrary to the exception is unenforceable (Article 3(2)). It is emphasised that research organisations should also benefit from the exception when they engage in publicprivate partnerships (Recital 10).

There are also other examples worth examining. For instance, the European Copyright Code drafted by the Wittem Project and published in 2010 proposes an innovative approach to list limitations in its Chapter $5 .{ }^{34}$ Limitations are classified under the following articles: Uses with minimal economic significance (Art. 5.1); Uses for the purpose of freedom of expression and information (Art. 5.2; which includes also "use for purposes of scientific research"); Uses permitted to promote social, political and cultural objectives (Art. 5.3); Uses for the purpose of enhancing competition (Art. 5.4). The list of limitations stipulated in Article 5.5. "Further limitations" is non-exhaustive, although it makes reference to the "three-step-test". The Code also clarifies the relation between limitations and moral rights (Art. 5.6).

To proceed from the concept of the well-known academics who drafted the Code, a combination of civil and common law approaches, language exceptions could be added to Art. 5.3, so as to promote social, political and cultural objectives.

Some countries have already taken the initiative to allow the development of language resources and TDM (e.g. the UK). ${ }^{35}$ For instance, Estonia has taken some steps to introduce an exception for data mining (applicable to copyright and

32 Communication from the Commission to the European Parliament, the Council, the European Economic and Social Committee and the Committee of the Regions. Towards a modern, more European copyright framework. Brussels, 9.12.2015. COM(2015) 626 final, pp. 6-9. Available at http://eur-lex.europa.eu/legal-content/EN/TXT/HTML/?uri=CELEX:52015DC0626\&rid=1 [last viewed August 21, 2016].

33 European Commission. Proposal for a Directive of the European Parliament and of the Council on copyright in the Digital Single Market. Brussels, 14.9.2016. COM(2016) 593 final. 2016/0280 (COD). Available at https://ec.europa.eu/digital-single-market/en/news/proposal-directiveeuropean-parliament-and-council-copyright-digital-single-market [last viewed September 29, 2016].

34 European Copyright Code. The Wittem Project. Available at www.copyrightcode.eu [last viewed August 21, 2016].

35 See Intellectual Property Office. Exceptions to copyright: Research. Available at https://www. gov.uk/government/uploads/system/uploads/attachment data/file/375954/Research.pdf [last viewed June 9, 2016]. 
related rights) in section 43 of the draft Copyright and Related Rights Act (2014). ${ }^{36}$ The draft provision allows: "Reproduction and processing of an object of rights for the purpose of text analysis and data mining, on the condition of attributing the name of the author of the used work, the name of the work and the source of publication, except if such attribution is impossible, and on the condition that such use is not carried out for commercial purposes". ${ }^{37}$ The provision on TDM in the draft Copyright and Related Rights Act of Estonia purports to create legal clarity in the future.

As for today, it can be concluded that language research (including the development of language resources) relies on the research exception rule in the Estonian Copyright Act. ${ }^{38}$ The Act contains a broad research exception ( $\$ 19$ clauses 2 and 3 ).

\section{Conclusions}

The article focuses on the digitalisation of the Estonian language. The goal of preservation of the Estonian language is defined in the preamble of the Estonian Constitution as a constitutional value and one of the main goals of the Republic of Estonia. This means that the Constitution and other laws (including the Copyright Act) have to be interpreted and implemented in the spirit of this objective. Since Estonian is a small language, there are no economic incentives to invest in its digitalisation. Therefore, it has to be carried out in the public interest.

The main conclusion is that the author's exclusive rights can be limited by constitutional values to allow the digitalisation of the Estonian language. The specific mechanism to achieve this objective lies within copyright law.

In order to digitise a language, a vast number of copyright-protected works need to be used to develop language resources. The digitalisation process can be patterned upon the contractual model (rightholder's consent to the use of material for the creation of LRs) or the exception model (the use of copyrighted material is based on the restrictions of copyright owner's exclusive rights).

Currently the digitalisation of the Estonian language is modelled upon a copyright exception allowing the free use of works for research purposes. The authors support the introduction of a mandatory text and data mining exception at the EU level as suggested in the Proposal for a Directive on copyright. Estonia has also incorporated the exception in its draft Copyright and Related Rights Act.

36 For further discussion on the Estonian IP law reform, see Kelli A. The conceptual bases for codifying Estonia's IP law and the main legislative changes: From the comparative approach to embedding drafted law into the socio-economic context. International Comparative Jurisprudence, 2015, No. 1(1), pp. 44-54. Available at http://www.sciencedirect.com/science/article/pii/ S2351667415000050 [last viewed August 21, 2016].

37 Autoriõiguse ja autoriõigusega kaasnevate õiguste seaduse eelnõu (The Estonian draft Copyright and Related Rights Act). (2014). Available at https://ajaveeb.just.ee/intellektuaalneomand/ [last viewed June 9, 2016].

38 Copyright Act. Available at https://www.riigiteataja.ee/en/eli/506042016003/consolide [last viewed August 21, 2016]. 


\section{BIBLIOGRAPHY}

\section{Literature}

1. Alexy R. Põhiõigused Eesti põhiseaduses (Fundamental Rights in the Estonian Constitution). Juridica, 2001, Special issue, pp. 5-96.

2. Ernits M., Roosma P., Kelli A. Commentaries on $\$ 32$ of the Constitution of the Republic of Estonia. In: Eesti Vabariigi põhiseadus. Kommenteeritud väljaanne. Kolmas, täiendatud väljaanne (Constitution of the Republic of Estonia, Commented Edition, Third Edition), edited by a panel led by Madise Ü. Tallinn: Juura, Õigusteabe AS 2012. Available at http://www.pohiseadus.ee/ public/EVPS_kommeteeritud_valjaanne_2012.pdf [last viewed August 21, 2016].

3. Ernits M. Põhiseaduse aluspõhimõtted (The Fundamental Principles of the Constitution). Riigikogu Toimetised, 2011, No. 24, pp. 95-104. Available at http://rito.riigikogu.ee/ eelmised-numbrid/nr-24/pohiseaduse-aluspohimotted/ [last viewed August 25, 2016].

4. Geiger C. Research Handbook on Human Rights and Intellectual Property Research Handbooks in Intellectual Property series. Edward Elgar, 2015.

5. Jents L., Kelli, A. Legal Aspects of Processing Personal Data in Development and Use of Digital Language Resources: the Estonian Perspective. Jurisprudence, 2014, No. 21(1), pp. 164-18. Available at https://www.mruni.eu/upload/iblock/fdd/JUR-14-21-1-08.pdf [last viewed August 16, 2016].

6. Kelli A., Vider K., Pisuke H., Lindén K. Digitaalsete keeleressursside loomist ja kasutamist määrav õiguslik raamistik Eestis ja selle ühildumine CLARIN-i infrastruktuuriga (Regulatory Framework Determining the Development and Utilization of Digital Language Resources and Technologies in Estonia and its Compatibility with CLARIN Infrastructure). Eesti Rakenduslingvistika Ühingu aastaraamat, 2016, No. 12, pp. 81-98. Available at http:// rakenduslingvistika.ee/ajakirjad/index.php/aastaraamat/article/view/ERYa12.05 [last viewed August 16, 2016].

7. Kelli A. The conceptual bases for codifying Estonia's IP law and the main legislative changes: From the comparative approach to embedding drafted law into the socio-economic context. International Comparative Jurisprudence, 2015, No. 1 (1), pp. 44-54. Available at http://www. sciencedirect.com/science/article/pii/S2351667415000050 [last viewed August 21, 2016].

8. Kelli A., Vider K., Lindén K. The Regulatory and Contractual Framework as an Integral Part of the CLARIN Infrastructure. Available at www.ep.liu.se/ecp/article. asp? issue $=123 \&$ article $=002$ [last viewed June 9, 2016].

9. Kelli A., Pisuke H. Commentaries on $\$ 39$ of the Constitution of the Republic of Estonia. In: Eesti Vabariigi põhiseadus. Kommenteeritud väljaanne. Kolmas, täiendatud väljaanne (Constitution of the Republic of Estonia, Commented Edition, Third Edition), edited by a panel led by Madise Ü. Tallinn: Juura, Õigusteabe AS 2012. Available at http://www.pohiseadus.ee/ public/EVPS_kommeteeritud_valjaanne_2012.pdf [last viewed August 21, 2016].

10. Kelli A., Tavast A., Pisuke H. Copyright and Constitutional Aspects of Digital Language Resources: The Estonian Approach. Juridica International, 2012, No. 19, pp. 40-48. Available at http://juridicainternational.eu/public/pdf/ji_2012_1_40.pdf [last viewed August 28, 2016].

11. Lewinski S. von. International Copyright Law and Policy. Oxford University Press, 2008; Walter M. M., von Lewinski, S. European Copyright Law: a Commentary. Oxford University Press, 2010.

12. Liin K., Muischnek K., Müürisep K., Vider K. Eesti keel digiajastul (The Estonian language in the digital age). Available at http://www.meta-net.eu/whitepapers/e-book/estonian.pdf [last viewed August 28, 2016]. 
13. Narits R. The Republic of Estonia Constitution on the Concept and Value of Law. Juridica International, 2002, No. 7, p. 13. Available at http://juridicainternational.eu/public/pdf/ ji_2002_1_10.pdf [last viewed August 28, 2016].

14. Narits R., Schneider H. Commentaries on preamble. In: Eesti Vabariigi põhiseadus. Kommenteeritud väljaanne. Kolmas, täiendatud väljaanne (Constitution of the Republic of Estonia, Commented Edition, Third Edition), edited by a panel led by Madise Ü. Tallinn: Juura, Õigusteabe AS 2012, p. 38. Available at http://www.pohiseadus.ee/public/EVPS kommeteeritud_valjaanne_2012.pdf [last viewed August 21,2016].

15. Ricketson S., Ginsburg J. C. International Copyright and Neighbouring Rights: The Berne Convention and Beyond. Second Edition. Volume I. Oxford University Press, 2006.

16. Tavast A., Pisuke H., Kelli A. Õiguslikud väljakutsed ja võimalikud lahendused keeleressursside arendamisel (Legal challenges and possible solutions in developing language resources). Eesti Rakenduslingvistika Ühingu aastaraamat, 2013, No. 9, pp. 317-332. Available at http://www. rakenduslingvistika.ee/ajakirjad/index.php/aastaraamat/article/view/228/0 [last viewed August 28, 2016].

17. Vasamäe E. Autoriõiguste ja autoriõigusega kaasnevate õiguste jätkusuutlik kollektiivne teostamine (Sustainable collective management of copyright and related rights). Doctoral thesis (supervisor Professor H. Pisuke) University of Tartu, 2014.

18. Vider K., Pisuke H., Mõtsküla P. P., Tuulik T., Kelli A. Keeleressursside litsentsimise õiguslikke küsimusi (Legal considerations in licensing language resources). Eesti Rakenduslingvistika Ühingu aastaraamat, 2013, No. 9, pp. 333-347. Available at http://www.rakenduslingvistika. ee/ajakirjad/index.php/aastaraamat/article/view/ERYa9.21 [last viewed August 16, 2016].

\section{Legislative acts}

1. Constitution of the Republic of Estonia. Available at https://www.riigiteataja.ee/en/ eli/521052015001/consolide [last viewed June 9, 2016].

2. Constitution of the Republic of Latvia. Translation available at http://www.saeima.lv/en/ legislation/constitution [last viewed June 9, 2016].

3. Constitution of the Republic of Lithuania. Available at http://www3.lrs.lt/home/ Konstitucija/Constitution.htm [last viewed June 9, 2016].

4. Copyright Act. Available at https://www.riigiteataja.ee/en/eli/506042016003/consolide [last viewed August 21, 2016].

5. Directive 2001/29/EC of the European Parliament and of the Council of 22 May 2001 on the harmonisation of certain aspects of copyright and related rights in the information society. Official Journal L 167, 22/06/2001 pp. 0010-0019.

6. Directive 96/9/EC of the European Parliament and of the Council of 11 March 1996 on the legal protection of databases. Official Journal L 077, 27/03/1996 pp. 0020-0028.

7. Directive 2001/29/EC of the European Parliament and of the Council of 22 May 2001 on the harmonisation of certain aspects of copyright and related rights in the information society. Official Journal L 167, 22/06/2001 pp. 0010-0019.

\section{Other sources}

1. Autoriõiguse ja autoriõigusega kaasnevate õiguste seaduse eelnõu (The Estonian draft Copyright and Related Rights Act). (2014). Available at https://ajaveeb.just.ee/ intellektuaalneomand/ [last viewed June 9, 2016]. 
2. CLARIN (Common Language Resources and Technology Infrastructure). Additional information available at https://www.clarin.eu/content/clarin-in-a-nutshell [last viewed August 16, 2016].

3. Communication from the Commission to the European Parliament, the Council, the European Economic and Social Committee and the Committee of the Regions. Towards a modern, more European copyright framework. Brussels, 9.12.2015. COM(2015) 626 final, pp. 6-9. Available at http://eur-lex.europa.eu/legal-content/EN/TXT/HTML/?uri=CELEX: 52015DC0626\&rid=1 [last viewed August 21, 2016].

4. Communication from the Commission to the European Parliament, the Council, the European Economic and Social Committee and the Committee of the Regions. Towards a modern, more European copyright framework. Brussels, 9.12.2015. COM(2015) 626 final. Available at http://eur-lex.europa.eu/legal-content/EN/TXT/HTML/?uri=CELEX:52015 DC0626\&rid=1 [last viewed June 9, 2016].

5. European Copyright Code. The Wittem Project. Available at www.copyrightcode.eu [last viewed August 21, 2016].

6. European Parliamentary Research Service. Review of the EU copyright framework. European Implementation Assessment, 2015, p. 20. Available at http://www.europarl.europa.eu/ RegData/etudes/STUD/2015/558762/EPRS_STU\%282015\%29558762_EN.pdf [last viewed June 9, 2016].

7. Intellectual Property Office. Exceptions to copyright: Research. Available at https://www.gov. uk/government/uploads/system/uploads/attachment_data/file/375954/Research.pdf [last viewed August 28, 2016].

8. Seletuskiri Eesti Vabariigi põhiseaduse muutmise seaduse eelnõu 974 SE juurde (Explanatory memorandum to the Constitution of the Republic of Estonia daft Amendment Act 974 SE). Available at http://www.riigikogu.ee/tegevus/eelnoud/eelnou/cf9123d5-108f-db00-8a4a2473d2abe91d/Eesti\%20Vabariigi\%20p\%C3\%B5hiseaduse\%20muutmise\%20seadus/ [last viewed August 25, 2016].

9. Triaille J.-P., de Meeûs d'Argenteuil J., de Francquen A. Study on the legal framework of text and data mining (TDM). Available at http://ec.europa.eu/internal_market/copyright/docs/ studies/1403_study2_en.pdf [last viewed June 9, 2016].

10. UNESCO. Atlas of the World's Languages in Danger. Available at http://unesdoc.unesco.org/ images/0019/001924/192416e.pdf [last viewed June 9, 2016]. 
Kalvis Torgans, Dr. habil. iur.

University of Latvia, Latvia

\title{
FAIR JUDGMENT IN CIVIL CASES AS \\ A MANIFESTATION OF IMPLEMENTING PROVISIONS OF THE SATVERSME
}

\begin{abstract}
Summary
The necessity to establish fair courts with the help of other laws and also to ensure their successful functioning follows from every person's right to a fair court enshrined in Article 92 of the Satversme (Constitution of the Republic of Latvia). ${ }^{1}$ The article presents reflections on what justice in civil law disputes is, and describes the obstacles and difficulties that a court must overcome to reach a fair judgement.
\end{abstract}

Keywords: a fair judgement, civil procedure, limitation period, cassation.

\section{Introduction}

The Constitution (Art. 92) creates preconditions for fair court judgements; however, the making of such depends also upon the fairness of laws that regulate the particular legal relationship, successful work of the court in establishing the truth and appropriate application of laws. Frequently, courts are being reproached in public space of passing unfair judgements. To reinforce fairness in the protection of persons' rights and lawful interests, laws and judicial procedures are being improved, measures are taken to impose discipline upon parties of civil disputes and to ensure quality in judges' work. The aim of the article is to analyse obstacles and difficulties that impact judges as they proceed towards a fair judgement and to show that achieving fairness depends upon active and bona fide participation of the parties of the civil dispute in establishing the circumstances of the case in full.

\section{Difference between the concepts of a fair court and a fair judgement by court}

To exercise every person's right to a fair trial, the State has an obligation to set up an appropriate system of judicial institutions to ensure the independence of

Latvijas Republikas Satversme: Latvijas Republikas likums. 15.02.1922. (Constitution of the Republic of Latvia. For the text in English, see: Latvijas Republikas Satversme. Latvijas Vēstnesis, [b.g., b.v.], pp. 273-300), and http://www.saeima.lv/en/legislation/constitution [last viewed March 8, 2017]. 
judges and to establish procedures, in which courts examine cases in a procedure that ensures fair and objective adjudication of these cases. ${ }^{2}$

The Constitutional Court, in interpreting the first sentence of Article 92 of the Satversme, has recognised that the concept of "a fair court" comprises two aspects; i.e., a fair court as an independent institution of the judicial power, which examines a case, and a fair court as a due procedure, appropriate for a state governed by the rule of law, in which the case is examined. ${ }^{3} \mathrm{~A}$ fair court as a due procedure, appropriate for a state governed by the rule of law, comprises a number of elements - interconnected rights. These include the right to access to court, the principle of parties' equality in adversary procedure, the right to be heard, the right to a reasoned court judgement, and the right to appeal. ${ }^{4}$ Independence of a court is contested rarely and without concrete evidence.

Establishment of a fair court creates pre-conditions for passing fair judgements; however, that does not mean that each judgement by such a court would be fair. The concepts "a fair court" and "a fair judgement by a court", although being closely interconnected, are different concepts. Judges are independent, and therefore compliance of their judgements with the requirement of fairness could not be ensured by imposing the obligation to pass only fair judgements. Undoubtedly, such judgements are expected and the laws regulating work of courts guide towards them. However, even if all requirements set for a fair court are met, there are no guarantees that society is going to perceive every judgement by the court in civil cases as being a fair judgement as to its content, and that it will, indeed, be such. Fairness is a philosophical category, which does not succumb to being defined in a law and for the measuring of which no safe yardstick exists. Innumerable different theories of fairness in legal relationships and criteria for ensuring it are found in philosophical and legal literature, starting with the findings by Plato, Aristotle, and Cicero, up to the concepts of contemporary scholars. Fairness in distribution of material goods, procedural fairness, social justice, political justice, correctional justice and other manifestations of fairness have been written about. ${ }^{5}$ Prof. D. Rezevska in her monograph "Significance and Application of General Legal Principles" notes that the principle of fairness is not the final purpose for the legal system of a democratic state governed by the rule of law; however, the author has not attempted to expand the definition of fairness, but examines a whole group of principles of fairness, the initial principle of which is, as follows: essentially

Latvijas Republikas Satversmes komentāri. VIII nodaḷa. Cilvēka pamattiesības. Autoru kolektīvs prof. R. Baloža zinātniskā vadībā. Riga: Latvijas Vēstnesis, 2011, pp. 124-125.

3 See Judgement of 5 March 2002 by the Constitutional Court in Case No. 2001-10-01, Para. 2 of the Findings, and Judgement of 20 December 2006 in Case No. 2006-12-01, Para. 9.3.

4 See Judgement of 5 November 2008 by the Constitutional Court in Case No. 2008-04-01, Para. 8.2, and Judgement of 17 May 2010 in Case No. 2009-93-01, Para. 8.3.

5 See, for example, Grigore-Bāra E. Taisnīgums kā tiesību kritērijs. Inovāciju juridiskais nodrošinājums. Latvijas Universitātes 70. konferences rakstu krājums. Rìga: LU Akadēmiskais apgāds, 2012, p. 268. etc. 
similar objects should be treated similarly. ${ }^{6}$ A number of other general principles are derived from it, inter alia: 1) nobody may enrich himself from his own illegal activities; 3) a general mistake creates rights; 3) the one, whose condition improves as the result of a certain activity, must cover the costs of this activity. ${ }^{7}$

A judge does not have the possibility to decide, which type of fairness to prefer; i. e. to choose, whether he exercises procedural, social, correctional or another type of justice. To a large extent, this has been already prescribed in laws. From the vantage point of a judge, fairness is such a resolution of an existing dispute that the court provides in accordance with its internal conviction and which is based upon evidence that has been thoroughly, completely and objectively verified, being guided by judicial consciousness, based upon the rules of logics, scientific findings and observations drawn from every-day experience. This definition, which comprises the provisions of Section 97 of the Civil Procedure Law, as well as the definitions included in Section 5, 8, 10, 193 and in other sections, cannot be exhaustive. It comprises a reference to the obligation of abiding both by the letter and the spirit of law, as well as to a subjective element - a judge's judicial consciousness, his knowledge of scientific findings, and life experience. Each of these may contain contradictions and obscurities. All the numerous requirements that a judge must comply with while proceeding towards a fair judgement comprise the possibility for questioning or contesting fairness of the judgement. Prof. V. Sinaiskis, in his own time (1935), wrote in a rather pessimistic tone about implementation of fairness: "The human court is only an imperfect manifestation of justice and of enforcing it upon the Earth.

Therefore, the human court, which is formally correct, quite often turns out to be unfair." ${ }^{\prime}$ In his understanding, genuine justice could be established only by the God. However, contemporary society has no better option, but to entrust resolution of civil disputes to judges, who have passed the assessment of their qualification and reputation as provided for in law, before the State has entrusted to them the office of a judge. The State has also established courts' internal control by providing for possibilities of appeal in the appellate and cassation procedure.

How often does a court turn out to be unfair - that is a question for discussions, and it seems that today, at least in those civil cases that have been heard in three instances, the final outcome is seldom unfair.

The problem of fairness covers not only a judge's assessment regarding the solution to a particular conflict, but also the issues of the fairness regarding the norms of substantial law, the thoroughness of facts, i. e., evidence, presented

Rezevska D. Vispārējo tiesību principu nozīme un piemērošana. Rīga: Daigas Rezevskas izdevums, 2015, pp. 31 and 81. Note: the text comprises a reference to Peczenik A. Principles of Law. The search for Legal Theory. Rechtstheorie, 1971, No. 1.

Ibid., p. 82.

8 Sinaiskis V. Civīltiesības. Latvijas vispārējo civiltiesību zinātniskā apstrādājumā. I. Vispārējie civiltiesību pamati (Prolegomena). Rìga: Akciju sabiedrības "Valters un Rapa" izdevumā, 1935, p. 251. 
to the court, as well as the fairness of some provisions in the procedure for examining disputes. In civil law, one of the two parties in dispute seldom considers the court's judgement to be fair, and individual's perception of fairness often differs from the one considered to be fair from the perspective of society's interest and which, to a greater or lesser extent, is reflected in legal provisions.

\section{Criteria of fairness and obstacles in a judge's path towards a fair judgement}

The fairness defined in law is the main criterion, in accordance with which judges in the contemporary society make their judgements. Let us examine an example, which reveals the need to compare an individual's understanding of a fair judgement with fairness from the perspective of the whole society's interests.

An heir had not within a year applied to a succession that had been opened and, thus, actually, had not accepted it. He is of the opinion that fairness must win, sooner or later, and requests the court to recognize his right to inheritance, but receives a refusal. The substantiation provided is that rights are expired, unless they have been exercised within a definite term. In this example, the limitation period defined in the law is of decisive importance, which shows that from the perspective of certainty of civil turnover, those terms are fair, in the framework of which claims must be initiated, disallowing prolonged uncertainty. This is the fairness defined by law.

A court examines civil cases pursuant to laws and implements the principle "but one justice and one law for all". In many cases, the law provides a clear answer regarding prevention of particular conflicts. If the facts are not disputed, then the judge may not deviate from the unequivocal provisions of the law, even if he thinks that he should do so in the particular case. There are issues, for example, regarding the amount of compensation for moral damage, which are not clearly defined in law and which the court must decide upon according to the sense of justice and general principles of law (Section 5 of the Civil Law). ${ }^{9}$ However, there are also complicated cases, when the law does not provide a clear answer, but the decisions cannot be left at the court's discretion. For example, the law gives no answer as to whether the members of the board of directors of a capital company may be removed without any restrictions, in particular, in the case of a woman, irrespective of the fact that she is pregnant, or in a case of a compensation for long delay of a flight - how to determine the exact time when the plane has arrived, is it the moment, when the aircraft touches down on the runway of the destination airport or the time when the aircraft door is opened. In such cases of unclear law, the judge must interpret the law in accordance with the general principles of

9 Civillikums (Civil Law). LR likums, pieṇemts 1937. gada 28. janvārī. Valdības Vēstnesis, 41, 20.02.1937. Hereinafter - CL. 
law. There is a possibility, which parties have begun to use more often, i.e., an opportunity to submit a constitutional complaint to the Constitutional Court regarding incompatibility of a norm with the Satversme. However, such cases constitute a negligible share of all the cases to be reviewed, and quite frequently end with a negative decision by the Constitutional Court. ${ }^{10}$ The Court has the right, pursuant to Section $5^{1}$ of the Civil Procedure Law, ${ }^{11}$ to refer a question for the preliminary ruling to the Court of Justice of the European Union (CJEU) regarding interpretation or validity of a norm in the European Union law. The number of such cases is also negligible.

Thus, on the path towards a fair judgement, the main task of the court is to establish facts that are essential in the case, to verify applicability of the legal norm referred to by the plaintiff to these facts and to define accordingly the legal consequences of applying it. However, this is not an easy task, the court must overcome various difficulties. Since the examination of a civil dispute takes the form of the contest of the parties', the court, although it must attempt to establish all the most essential circumstances, has neither the possibility, nor the obligation to obtain the whole totality of facts. The court is guided by arguments and counter-arguments presented by the parties, in contrast to the inquisitorial principle, which is implemented in criminal and administrative proceedings. Thus, it is quite normal that there may be judgements, which objectively do not lead to a fair resolution of dispute, but the court, which stated that on those grounds, up on which the claim was brought, and according to the evidence submitted, the claim must be satisfied. For example, norms regulating lease contract were used to substantiate the claim; there was no lease agreement. The claim was rejected. However, if it had been substantiated by norms on unfounded enrichment or delict, it, most probably, would have been satisfied. The possibility to bring a new claim, with different substantiation, remains; however, the losing side usually perceives rejection of a claim as unfair and does not consider bringing another claim. A situation, where following a judgement of the first instance court, a party recalls one more item of evidence or a counter-argument to the claim is similar. The Supreme Court has provided the following explanation in one of its judgements:

"Pursuant to the adversary principle established in civil procedure, the participants of the case themselves decide on the scope of exercising their procedural rights. In the absence of a claim requesting recognising a transaction as being invalid and party's objections against the respective act, the court has no legal grounds for examining the legality thereof. The court of appellate instance examines only

10 In 2015, the Constitutional Court out of 269 applications has recognised 116 as obviously not falling within its jurisdiction, has examined 19 cases, judgements have been passed in 16 cases, of which in 12 cases the legal norms have been recognised as being compatible with the Satversme. The contested norm has been recognised as being incompatible with the Satversme in three cases. Available at http://www.satv.tiesa.gov.lv/blog/2016/02/10/parskats-par-satversmes-tiesas-darbu2015-gada/ [last viewed March 8, 2017].

11 Civilprocesa likums (Civil Procedure Law). LR likums, pieṇemts 14.10.1998. Latvijas Vēstnesis, 326/330, 03.11.1998. Hereinafter - CPL. 
those claims that have been examined at the first instance court (the second part of Section 426 of the Civil Procedure Law). Admitting that examination of the respective claim does not fall with the jurisdiction of the appellate instance court, it does not have the right to pass a judgement on rejecting such a claim." ${ }^{2}$

It is often noted in cassation complaints that the court has failed to explain to the participants of the case their rights and obligations as stipulated in Section 8 of the Civil Procedure Law; however, this norm cannot be interpreted as the obligation of a court to instruct any of the parties on what should be done to win in the dispute.

Another hindrance in the path to a fair judgement is the fact that a court does not have at its disposal sufficiently efficient measures for preventing dishonest actions by the participants of the case, lying, distorting facts, involving false witnesses, as well as delaying examination of the case. These obstacles are characterised in Section 4 of the article.

\section{Collision of principles}

The opinion that the law is a reflection of justice is widespread. This is predominantly so. However, the legislator's decision to select one or another solution in cases, where interests and understanding of fairness collide, may lead to initially unpredicted distortions of justice. After Latvia regained independence, the issue, whether to return immoveable property to those, from whom the Soviet power had illegally taken it, including land plots, on which a building belonging to another person had been constructed, gained relevance. It was decided to return the properties to the former owners, however, it caused a situation similar to lease relationship, i.e., the enforced lease. It is a major question, whether at the time it was possible to predict that many former victims of Soviet expropriation, after regaining their land, would start increasing lease payments ruthlessly, exercising the owner's right to the total power established in the Civil Law, without caring in the least for the apartment and house owner's and tenant's solvency. Now the situation is dealt with by drafting a law to end the divided property with the help of pre-emption. And, as it could have been predicted, the issue of sacredness of property right and the owner's right to set his demands with regard to the amount of payment turned into the main object of dispute and discussions of fairness. In March 2016, more than 20 years later, the Saeima decided to create opportunities to end the divided property and facilitate this process by pre-emption. ${ }^{13}$ Adoption of

12 Latvijas Republikas Augstākās tiesas Senāta Civillietu departamenta 2010. gada 22. decembra spriedums lietā Nr. SKC-966. Available at http://at.gov.lv/lv/judikatura/judikaturas-nolemumuarhivs/senata-civillietu-departaments/klasifikators-n/ [last viewed March 8, 2017].

13 Projekts: Piespiedu dalītā īpašuma tiesisko attiecību privatizētajās daudzdzīvokḷu mājās izbeigšanas likums. Pieñemts Saeimā 1. lasījumā 17.03.2016 (No. 395/Lp12). Available at http://titania.saeima. lv/LIVS12/saeimalivs 12.nsf/webAll?SearchView\&Query $=\left([\right.$ Title $]={ }^{*}$ dalītā+īpašuma+izbeigšanas* $)$ $\&$ SearchMax $=0 \&$ SearchOrder $=4$ [ last viewed June 26, 2016]. 
the law will not be able to solve all the collisions of interests related to divided property, e.g. land plots, on which stand buildings belonging to another person. A number of case categories have emerged in the case law, where two or more principles of law collide and the court must find fair commensurability in their interaction.

For example, in cases of infringements upon dignity, respect and privacy, such fundamental rights as the right to speech (freedom of press) and the rights of everyone to inviolability of dignity, respect and private life collide. The press, which calls itself a watchdog, in hostile tones has criticised a high standing official, disdainfully comparing him to an animal. The journalist and the publisher state that an opinion has been expressed and that the freedom of speech allows doing it. Representatives of the plaintiff consider that, even in expressing an opinion, one must remain within the limits of politeness. The judges, who hear these cases, already have learnt a lot from the findings expressed in judgements by ECHR. ${ }^{14}$ However, it is impossible to define in judicature once and for all, how the limit should be drawn in the case, when these two principles collide.

There have been many disputes in legal literature, whether illegally alienated property should always be returned to the previous owner, or whether, in certain situations, a preference should be given to the principle of protecting a bona fide acquirer.

In Latvia, judgements have been passed in several civil cases, in which the court had to determine, whose right to property should be recognised, when the property had illegally left the owner's possession and had been sold several times. The initial owner submits a claim to the court, requesting to recognise his right to property. Usually, such claims have been heard in three instances and the final word has been said by the Supreme Court. And it is the rulings by the Supreme Court, where a certain contradiction is seen: in some cases, the claim has been satisfied, in others - rejected. Prior to examining the essence of the problem and arguments, one is inclined to say that both variants are possible, because the resolution depends upon numerous facts. The law does not directly state that immoveable property should, in all cases, be returned to the person, who once has been its owner. The Supreme Court has recognised that, as regards immoveable property, the principle of Roman law 'I claim my thing where I find it' is not applicable. Likewise, due to public credibility of the Land Register, the issue of the owner is complicated, if it is resold by a person, whose ownership has been entered into the Land Register. From the perspective of criminal law, the issue of what kind of money - illegally obtained or another has been used to acquire immoveable property is complicated.

14 Judgement of 6 May 2004 by ECHR in Case Environment Protection Club v. Latvia; Judgement of 14 January 2014 by ECHR in Case Ojala and Etukeno Oy v. Finland; Judgement of 7 February 2012 by ECHR [Grand Chamber] in Case von Hannover v. Germany (No. 2), see also: Eiropas Cilvēktiesību tiesas prakse, līdzsvarojot tiesības uz privātās un gimenes dzīves neaizskaramību un izteiksmes brīvibu. Eiropas Cilvēktiesību tiesas (ECT) spriedumu apkopojums. Sast. A. Zikmane, R. Markvarts, 09.05.2016. Available at http://at.gov.lv/lv/judikatura/ect-nolemumi/ectspriedumu-apkopojumi/ [last viewed March 8, 2016]. 
Attempts to prove, which of the principles prevails, are not convincing. The analysis of consequences that the implementation of principles might lead to could be more convincing, but until now it has received little attention. Thus, we shall analyse the consequences of a judgement, if a court, ignoring four purchase agreements that had been concluded after the murder of an apartment's owner, were to decide that the apartment should be taken away from the fourth acquirer and returned to the heiress of the murdered owner. Thus, this judgement would recognise four agreements as being invalid as of the moment they were concluded. The fourth acquirer would bring a claim against the third (who sold him the apartment), demanding repayment of the money that had been paid. Would it be fair to reject this claim in the presence of any evidence of the bad faith of the buyer and the defendant's arguments that he had acquired the apartment as a result of a notarial purchase from an owner, who had been entered into the Land Register, and if there were no evidence whatsoever about his cooperation in bad faith with the murderers of the previous owner? As the case materials show, apart from this claim, he would also bring a claim to receive compensation of expenses incurred by renovating the apartment, in the amount of several thousands, most probably, against the person, who would be awarded the apartment. If the court were to satisfy the claim for repayment of the paid money, then also the third acquirer would bring similar claims against the second, and the second against the first one. By awarding the apartment to the heiress of the murdered owner, it would seem that the justice has triumphed with respect to the heiress. However, it is doubtful, whether the same could be said with respect to the three other participants of civil turnover. Moreover, trust in the credibility of entries into the Land Register would be seriously undermined, and that would affect a large number of persons. This would cause a situation, where no acquirer of immoveable property would feel safe, fearing that in a couple of years' time a series of three or five transactions could be discovered, where the claimant would succeed in contesting the initial transaction.

Another solution is possible, allowing to protect the interests of the person, who has suffered because of illegal alienation, sufficiently well. The claimant is interested in an apartment, a house or a land plot in a certain location and of a certain quality. If there were serious obstacles to satisfying the claim in kind, the value of such property could be compensated for in cash, allowing to acquire immoveable property of corresponding quality, without creating the chaos that would be caused by another judgement in the case described above.

It seems to be simple, but it is dangerous to entrust solving complications of this nature to the person directing criminal proceedings or to a court, which is not examining this issue in legal proceedings according to the Civil Procedure Law, but as an issue of criminal procedure regarding returning an illegally obtained property to its previous owner, as stipulated by Section 356 and Section 360 of the Criminal Procedure Law. Combating crimes, in which material values are obtained, undoubtedly, is very important and requires strict and definite actions 
by the person in charge of proceedings. However, this issue is to be solved in interconnection with other provisions of law, no less important. On 12 May 2016, the Constitutional Court initiated case "On Compliance of the second part of Section 356 and the first part of Section 360 of the Criminal Procedure Law with Article 1, the first sentence of Article 91, Article 92 and Article 105 of the Satversme of the Republic of Latvia". ${ }^{15}$ This wording, actually, hides the problem of protecting a bona fide acquirer in criminal proceedings. The first part of Section 360 of the Criminal Procedure Law provides: "If criminally acquired property has been found on a third person, such property shall be returned, on the basis of ownership, to the owner of lawful possessor thereof". The second part of Section 356 of this Law, in turn, provides that during pretrial criminal proceedings in certain cases property may be recognised as being criminally obtained also by the decisions of a district (city) court or the person directing the proceedings.

The facts indicated in the application point to the significance of the issue. Joint stock company "DNB banka" (the applicant) in 2011 acquired immoveable property (an apartment) at an auction. After several years, in 2015 , this property was recognised as being criminally obtained, since the initial owner had lost it because of a criminal offence, he had been defrauded of the apartment, which was later sold to another person, who corroborated his rights in the Land Register. Finally, the property ended up in the applicant's ownership. The applicant considers itself to be a bona fide acquirer of the property, while the person directing criminal proceedings, on the basis of contested norms, adopted the decision to return immoveable property to its initial owner. The applicant holds that the contested norms restrict applicant's right to property and are incompatible with the principle of legal certainty. The rights of a bona fide acquirer of property are said to be protected in civil procedure, whereas in the framework of criminal proceedings the contested norms do not envisage protection like this, and the property is taken away, notwithstanding the acquirer's good faith. Allegedly, the contested norms also fail to comply with the right to a fair trial, since the applicant may appeal against the investigator's decision on returning the illegally obtained property to its initial owner only to the Prosecutor's office, but not to a court. The Constitutional Court decided that the contested Sections of Criminal Procedure Law comply with the Satversme. ${ }^{16}$ However, the problem who is a bona fide acquirer seems not to be solved with finality.

15 Case of the Constitutional Court No. 2016-07-01. Date of initiation: 12.05.2016. Available at http://www.satv.tiesa.gov.lv/cases/_[last viewed March 16,2016].

16 Judgement of 8 March 2017 by the Constitutional Court in the Case No. 2016-07-01 http://www. satv.tiesa.gov.lv/wp-content/uploads/2016/05/2016-07-01 Spriedums.pdf [last viewed March 8, 2017]. 


\section{Counter-actions by the participants of a dispute to fast and fair adjudication of a civil case}

The court must proceed towards a fair solution in circumstances of implementing the adversarial principle. This means that all parties are trying to prove the facts that favouring themselves and to refute the evidence presented by the other party. The court, however, is not a passive observer of the contest, but has limited possibilities to form a complete picture of the events. In the huge flow of civil cases coming to courts, a trend can be observed that the defendants and sometimes also the other persons involved in the case avoid fast and full adjudication of the case. Sometimes this signals the wish to evade fair satisfaction of the claim and the enforced collection following it, which, in turn, delays proceedings in the case and increases the workload of courts.

Everyone's right to turn to court and to be heard is enshrined in Article 92 of the Satversme. To exercise it, everyone involved in a civil dispute should be duly informed. Thus, the procedure of delivering and serving notices and other court documents is important.

In practice, regretfully, counter-activities by the defendant and sometimes also by other participants of a civil case are observed, which can be manifested, as follows:

1) the defendant avoids receiving the true copy of the statement of claim and other documents sent by the court,

2) takes actions to delay legal proceedings,

3) alienates or encumbers the object of dispute.

Evasion by defendants, numerous debtors, failing to pay credits, and other debtors, to receive any court documents, i.e., concealing one's place of residence, is a typical contemporary phenomenon. Not infrequently such defendants later attempt to contest court rulings, stating that they are not to be blamed for failing to receive the information about an opportunity to defend their rights at court, but instead it has happened because of the postal errors, changing the place of residence, due to a business trip, disease or other obstacles.

This causes a need to implement organisational measures, as well as to envisage counter-steps in the Civil Procedure Law, reinforcing sanctions for such activities. A united, electronic system of forwarding court summons has been set up, it records the exact time, when the summons have been delivered to the post office, with a note that a registered mail or registered mail with a notice of receipt is to be sent. The obligation has been imposed upon the court to verify, whether the address of the plaintiff or the third person, indicated in the claim application, complies with the declared place of residence. The monetary fine that the court can impose upon a participant of a case for failure to inform about the change of address has been increased to 50 EUR. A procedure for delivering and serving documents has been extensively defined. All this allowed introducing, by amendments to the Civil Procedure Law that entered into force on 1 January 2013, a previously unknown presumption in civil procedure - the presumption of 
the receipt of documents (CPL Section $\left.56^{1}\right) \cdot{ }^{17}$ The presumption can be refuted, but only by concrete evidence. The Supreme Court holds that this reorganisation has imposed discipline upon participants of disputes, decreased complaints in connection with the right to be heard. Failure to receive a notice of the time and place of a court hearing does not constitute grounds for cassation, if the court has abided by the requirements regarding delivery of notice.

The presumption on serving the notice decreases the possibility to blame a court for lengthy legal proceedings and allows reaching clarity in other cases faster. Of course, there are cases, where the defendant, if he had received the summons and arrived in court, would have been able to decrease liability or even be released from it. In exceptional cases (for example, due to postal error or because the defendant had been in hospital), following a prosecutor's protest, the court has to return to hearing of the case on its merits; however, as regards the aspect of fairness, it must be underscored that the court acts in accordance with the adversarial principle, and each party in the case must show sufficient care to ensure that he can be reached at the declared place of residence, so that objections to the claim would appear already in the explanations with regard to the statement of claim, and, in case of necessity, an authorised representative would come to court. Predominantly, the rights of the parties have been discussed in legal literature; however, it should be emphasized that the parties have also obligations, inter alia, to facilitate thorough and fast examination of the case. Additionally, this follows from the seventh part of CPL Section 74, as well as other provisions of this law.

The court may not be reproached of an unfair judgement, if the failure by the claimant to abide by procedural rules, to submit evidence or the choice of wrong grounds for the claim has lead to a rejection of the claim, although compliance with the indicated requirements would have led to the opposite result. The addressee of these reproaches should be the claimanthimself.

The rhythm of a court's work is quite often disrupted by the need to postpone hearing of the case, because one of the parties, a third person or the advocate has not arrived. Measures have been introduced also to decrease such obstacles by more strictly requiring presentation of medical certificates, as well as by introducing an electronic calendar reflecting the workload of advocates in judicial institutions.

To make a fair judgement, a complete information about the circumstances of the case, the truth about the facts must be established. Regretfully, counteractivities are seen also in this respect, since usually one of the parties to the dispute is not interested in honest and objective disclosure of all facts. To facilitate establishment of the truth and to combat lies in court, on 26 May 2015 Section $9^{1}$ was added to the Civil Procedure Law, defining the obligation of the participants of the case to provide true information about the facts and circumstances of the case, in Section $73^{1}$ also establishing monetary fines for

17 Grozījumi Civilprocesa likumā (Amendments to Civil Procedure Law). 2012. gada 29. novembra likums // Latvijas Vēstnesis, 14.12.2012., No. 197. 
breaching this obligation. The obligation of telling the truth existed also before these amendments; however, it is hoped that these amendments will make the courts respond more actively to manifest distortion of facts, which, under the circumstances where the parties are adversaries, is not a rare phenomenon.

\section{The right to access to court and possibilities of appeal}

Latvia has a three-tier court system. Its existence has created a widely spread public opinion that the genuine truth can be established only by the Supreme Court as the cassation instance, ${ }^{18}$ and, therefore, it should be possible to appeal against each judgement by a first instance court in a civil dispute both in appellate and in cassation procedure. For a long time, such possibilities, indeed, existed. The feeling that the hearing of a case in a first instance court was only "a warm-up" of a kind and that the main fight would take place in the appellate instance prevailed even in the circles of legally educated lawyers - advocates; however, failing to reach "one's truth" there, the possibility to do that at the cassation court still remained. However, practice showed that a rather large part of cassation complaints did not comprise arguments, for the examination of which the cassation court had been created. The cassation instance court was increasingly overburdened with cases, ${ }^{19}$ urging to change the position. A panel of three judges of the Department decides on initiating cassation legal proceedings at an assignment hearing. In such a case, it is important to establish, whether the submitter of cassation complaint is presenting concrete arguments and evidence that he would have used, had he participated at the court sitting. The argument that a participant in the case has the right to be heard and that he had no possibility to object is not sufficient, indications of errors that could have arisen are required and need to be verified.

In 2015, the assignment sitting of the judges' panel refused to initiate cassation proceedings in 1245 cases, which constitute 79 per cent of the number of cassation complaints received, in 2014 the rate of rejection was 74 per cent of cassation complaints. ${ }^{20}$ Quite often, the decisions of refusal to initiate cassation legal proceedings quote the task of a cassation instance court, defined by professor V. Bukovskis, to examine only the cases that comprise quaestiones iuris, i.e., issues regarding the correctness of application of substantial and procedural norms. ${ }^{21}$ This even led to a number of constitutional complaints to

18 Until 2014 the Department of Civil Cases of the Supreme Court Senate of the Republic of Latvia was the cassation instance, which was later transformed into the Department of Civil Cases of the Supreme Court.

19 In 2013, the average number of examined cases per one judge at the Department of Civil Cases was 113 , in 2014, -97 cases.

20 Publiskais pārskats par Latvijas Republikas Augstākās tiesas darbu 2015. gadā. Augstākās Tiesas Biletens, Nr. 12, 2016. gada aprilis, 95. lpp.

21 Bukovskis V. Civilprocesa mācības grāmata, Rīga, 1933., pp. 461-465. 
the Constitutional Court, pointing to unlawful denial of the right to access to court, violation of the right to a fair court.

For example, in Case No. 2013-02-01, heard by the Constitutional Court, the applicants requested recognising Para. 2 of the second part of Section $464^{1}$ of the Civil Procedure Law as being incompatible with the first sentence of Article 92 of the Satversme. The contested norm regulates the right of the Supreme Court Senators to refuse initiating cassation legal proceedings in cases, when the cassation complaint formally complies with all the requirements that have been set, but the panels of Senators do not doubt the legality of the contested judgement.

The applicants state that their right, enshrined in Article 92 of the Satversme, is infringed upon. The State, in guaranteeing the right to appeal against a court's decision, pursuant to Article 92 of the Satversme should also guarantee accessibility of this right to all persons; however, the contested norm is said to deny it, since it defines the rights of a Senator's panel to refuse initiating cassation legal proceedings without any substantiation whatsoever, even if the cassation complaint meets all requirements of CPL Sections 450-454. The applicants referred to the case law of the Constitutional Court and ECHR to note that restrictions upon rights defined in Article 92 of the Satversme may not be of the kind that essentially denies the right to a fair court. The Constitutional Court did not uphold these arguments and recognized that the initial review of a cassation complaint at a Senate's assignment hearing, chosen by the legislator, was a properly selected measure for ensuring due functioning of the cassation instance. A person's subjective right to appeal against each ruling by a court does not follow from Article 6 of the European Convention for the Protection of Human Rights and Fundamental Freedoms. Each State itself may define the scope for the principle of appeal pursuant to its legal system. The right of access to appellate and cassation instance court does not comprise the requirement to examine every case on its merits and to prepare a full court's judgement. Hence, the contested norm does not infringe upon the right to access to court that follows from the first sentence of Article 92 of the Satversme.

However, to prevent any further complaints or applications to the Constitutional Court or the European Court of Human Rights, the Saeima on 9 June 2016 specified CPL Sections 464 and $464^{1} \cdot{ }^{22}$ The following provision was added to CPL Section 464: "(7) If the panel of judges has no obvious grounds to consider that by examining the ancillary complaint, the decision that has been appealed against would be revoked or amended fully or in the part thereof, then the assignment hearing of the Supreme Court may refuse, by unanimous vote, to accept the auxiliary complaint. In such a case the state fee for the auxiliary complaint shall not be repaid." Section $464^{1}$, in turn, specifies the grounds for refusing to initiate cassation legal proceedings, providing that this is to be done,

22 Grozijumi Civilprocesa likumā (Amendments to the Civil Procedure Law). LR likums, pieṇemts 09.06.2016. Latvijas Vēstnesis 123 (5695), 29.06.2016. 
if 1) the Supreme Court judicature has already evolved with regard to issues of applying the legal norms indicated in the cassation complaint and if the appealed judgement complies with it; 2 ) in assessing the arguments referred to in the cassation complaint, no obvious grounds are identified to consider that the outcome of the case that the appeal against judgement comprises is incorrect, and that the case under review is of essential importance in ensuring uniform case law or development of law. The third part has been added to this Section, worded, as follows: "(3) If the cassation complaint formally complies with the requirements set forth in the first part of this Section and if the court has not violated the provisions of the third part of Section 453 of this law and the case is not of essential significance in ensuring a uniform case law and law development, the panel of judges may refuse initiation of cassation legal proceedings also in disputes of material nature, if the part, regarding which the judgement has been appealed, is below 2000 euro."

The abovementioned considerations show that the legal science and the case law still have the task to consider additions and amendments that would allow preventing at least part of doubts about fairness of legal proceedings, as well as eliminating uncertainties in norms of substantial law, to facilitate implementation of the idea of fairness.

Numerous obstacles that hinder a court from making a fair judgment were not presented here with the aim to justify court's errors in those cases, when the court has failed to do everything envisaged in law. A state, where all the judgements would be fair, is an ideal to strive for, but, most probably, it will remain an ideal. However, courts should reinforce their efforts to make reasoning in the judgement convincing, promote the understanding of the letter and the spirit of law in society. Society, in turn, should show a greater respect to judges, to whom the State has granted its trust and the task to come to assistance to parties in disputes as neutral mediators, and who are using all the possible means in their attempts to reach a fair regulation of disputes.

\section{Conclusions}

1. The constitutional provision on the right to fair court creates preconditions for fair court judgements; however, the making of such depends upon a court's successful work in establishing the truth and appropriate application of laws, from whether the participants in a civil law dispute act in disciplined way and exercise their rights with integrity, but sometimes also upon the fairness of laws.

2. Legal provisions enshrine the criterion of justice in compliance with the interests of society as a whole, and sometimes they differ from an individual's understanding of the criteria of fairness.

3. From a judge's perspective, fairness is such a resolution of an existing dispute that the court provides in accordance with its inner conviction and which 
is based upon thoroughly, completely and objectively verified evidence, following judicial consciousness, based upon laws of logic, scientific findings and observations made in everyday life. All of the numerous requirements that a judge must abide by, while proceeding towards a fair judgement, comprise the possibility to doubt or to contest the fairness of a judgement. The grounds for contesting are not always found, but it often delays the final solution of a dispute.

4. The presumption on serving a notice reduces the possibility to blame the court for lengthy legal proceedings; however, it does not release the court from the obligation to try to establish the true circumstances of the case that are necessary for solving a dispute.

5. A court may not be reproached of an unfair judgement in a case, where the failure to abide by the procedural rules by the claimant, to submit the necessary evidence or stating the wrong grounds has led to rejection of the claim, although compliance with the indicated requirements would have led to the opposite result. The addressee of these reproaches should be the claimant himself.

\section{BIBLIOGRAPHY}

\section{Literature}

1. Bukovskis V. Civilprocesa mācības grāmata, Rīga, 1933.

2. Grigore-Bāra E. Taisnīgums kā tiesību kritērijs. Inovāciju juridiskais nodrošinājums. Latvijas Universitātes 70. konferences rakstu krājums. Rīga: LU Akadēmiskais apgāds, 2012.

3. Latvijas Republikas Satversmes komentāri. VIII nodaḷa. Cilvēka pamattiesības. Autoru kolektīvs prof. R. Baloža zinātniskā vadībā. Rīga: Latvijas Vēstnesis, 2011.

4. Rezevska D. Vispārējo tiesību principu nozīme un piemērošana. Rīga: Daigas Rezevskas izdevums, 2015.

5. Sinaiskis V. Civīltiesības. Latvijas vispārējo civiltiesību zinātniskā apstrādājumā. I. Vispārējie civiltiesību pamati (Prolegomena). Rīga: Akciju sabiedrības "Valters un Rapa" izdevumā, 1935.

\section{Legislative acts}

1. Latvijas Republikas Satversme: Latvijas Republikas likums. 15.02.1922. (Constitution of the Republic of Latvia. Text in English available at Latvijas Republikas Satversme. Riga: Latvijas Vēstnesis, [b.g., b.v.], pp. 273-300) and http://www.saeima.lv/en/legislation/ constitution [last viewed March 8, 2016].

2. Civillikums: LR likums, pieñemts 1937. gada 28. janvārī. "Valdības Vēstnesis”, 41, 20.02.1937. Civilprocesa likums: LR likums, pien̦emts 14.10.1998. "Latvijas Vēstnesis” 326/330, 03.11.1998.

3. Grozijumi Civilprocesa likumā: LR likums, pieņemts 2012. gada 29. novembrī. Latvijas Vēstnesis, 14.12.2012., Nr. 197.

4. Grozijumi Civilprocesa likumā: LR likums, pieņemts 2016. gada 9. jūnijā. Latvijas Vēstnesis 123 (5695), 29.06.2016. 


\section{Legal practice}

1. Publiskais pārskats par Latvijas Republikas Augstākās tiesas darbu 2015. gadā, Augstākās Tiesas Biletens, Nr. 12, 2016. gada aprïlis.

2. Judgement of 6 May 2004 by ECHR in Case: Environment Protection Club v. Latvia.

3. Judgement of 14 January 2014 by ECHR in Case: Ojala and Etukeno Oy v. Finland

4. Judgement of 7 February 2012 by ECHR [Grand Chamber] in Case: von Hannover v. Germany.

5. Judgement of 5 March 2002 by the Constitutional Court in Case No. 2001-10-01 Judgement of 20 December 2006 by the Constitutional Court in Case No. 2006-12-01 Judgement of 5 November 2008 by the Constitutional Court in Case No. 2008-04-01 Judgement of 17 May 2010 by the Constitutional Court in Case No. 2009-93-01. Judgement of 21 October 2013 by the Constitutional Court in Case No. 2013-02-01.

6. Case of the Constitutional Court No. 2016-07-01. Date of initiation: 12.05.2016. Available at http://www.satv.tiesa.gov.lv/cases/ [last viewed July 7, 2016].

7. Judgement of 8 March 2017 by the Constitutional Court in the Case No. 2016-07-01. Available at http://www.satv.tiesa.gov.lv/wp-content/uploads/2016/05/2016-07-01_ Spriedums.pdf [last viewed March 16, 2017].

8. Latvijas Republikas Augstākās tiesas Senāta Civillietu departamenta 2010. gada 22. decembra spriedums lietā Nr. SKC-966. Available at http://at.gov.lv/lv/judikatura/judikaturasnolemumu-arhivs/senata-civillietu-departaments/klasifikators-n/ [last viewed March 8, 2017].

9. Eiropas Cilvēktiesību tiesas prakse, līdzsvarojot tiesības uz privātās un gímenes dzīves neaizskaramību un izteiksmes brīvibu. Eiropas Cilvēktiesību tiesas (ECT) spriedumu apkopojums. Sast. A. Zikmane, R. Markvarts, 09.05.2016. Available at http://at.gov.lv/lv/ judikatura/ect-nolemumi/ect-spriedumu-apkopojumi/ [last viewed March 8, 2017]. 
Kaspars Balodis, Dr. iur.

University of Latvia, Latvia

\title{
CASE LAW OF THE CONSTITUTIONAL COURT AND PRIVATE LAW
}

\begin{abstract}
Summary
Case law of the Constitutional Court of the Republic of Latvia (hereinafter also the Constitutional Court) has a significant impact upon solutions of private law (civil law) problems. Sometimes compliance of legal norms with the Satversme (the Constitution of the Republic of Latvia) is contested, because the norm has infringed upon such fundamental human rights of the applicant, the exercise of which is linked to his or her rights and interests in the field of private law. If the Constitutional Court recognizes the contested norm as being unconstitutional, this gives a person legal grounds to defend his or her rights in a court of general jurisdiction or an administrative court.
\end{abstract}

Keywords: constitution, fundamental human rights, private law, case law of constitutional court.

\section{Introduction}

The Satversme and the Constitutional Court Law define the jurisdiction of the Constitutional Court. Pursuant to Article 85 of the Satversme and Para. 1 of Section 16 of the Constitutional Court Law, the Constitutional Court reviews cases regarding compatibility of laws with the Satversme. ${ }^{1}$ Para. 3 of Section 16 of the Constitutional Court Law provides that the Constitutional Court examines also compatibility of other regulatory enactments or parts thereof with legal norms (acts) of higher legal force. The jurisdiction of the Constitutional Court comprises also other issues listed in Section 16 of the Constitutional Court Law. The Constitutional Court does not hear civil disputes, which are resolved by courts of general jurisdiction. However, in a nation governed by the rule of law, public law and private law, or civil law, interact closely. This interaction is manifested as a horizontal impact of fundamental human rights upon legal relationships between private law subjects, recognised in the case law of constitutional courts and in legal doctrine. ${ }^{2}$

Assessing, whether courts of general jurisdictions in their judgements delivered in civil cases have abided by the Satversme, does not fall within the jurisdiction of the Constitutional Court. However, the Constitutional Court in its practice quite

1 See more on the jurisdiction of the Constitutional Court: Rodina A., Spale A. Commentary to the Artice 85 of the Satversme. Latvijas Republikas Satversmes komentāri. VI nodala. Tiesa. VII nodaļa. Valsts kontrole. Autoru kolektīvs prof. R. Baloža zinātniskā vadībā. Rìga: Latvijas Vēstnesis, 2013, pp. 127-144.

2 See more: Štarks K. (Starck Ch.). Pamattiesības un privāttiesības: pamattiesību teorija, Vācijas Pamatlikums un Federālās konstitucionālās tiesas prakse. Jurista Vārds. 26.03.2008., No. 12, pp. 14-21. 
often deals with cases regarding constitutionality of such legal norms, which not only infringe upon persons' rights enshrined in the Satversme, but also hinder these persons in exercising their subjective private rights. I.e., applicants have turned to the Constitutional Court, because, due to possible unconstitutionality of the legal norm applied to them, they had been unable to achieve protection of their rights by general legal remedies. If the Constitutional Court recognizes the contested norm as being incompatible with the Satversme, then the person may have the grounds to achieve protection of his or her rights at a court of general jurisdiction or an administrative court, for example, receive a compensation for damages or other kind of satisfaction. Turning to the Constitutional Court is a subsidiary legal remedy, useful not only in protection of fundamental rights, but also, indirectly, of subjective private rights.

This report analyses a selection of a number of rulings by the Constitutional Court that examined compliance of legal norms with the provisions of Chapter VIII of the Satversme "Fundamental Human Rights" and, at the same time, are linked to persons' rights and interests in the fields of property law, family law and labour (employment) law. Compliance of contested norms with such fundamental rights as the right to property (Article 105 of the Satversme), right to inviolability of private life (Section 96 of the Satversme), right to freely choose one's employment (Section 106 of the Satversme), right to receive commensurate compensation for work done (Article 107 of the Satversme) has been analysed in these rulings.

\section{Protection of the right to property at the Constitutional Court}

Everyone's right to property has been enshrined in Article 105 of the Satversme. The right to property is a fundamental human right that is closely linked to private law, inter alia, right to property regulated in the Civil Law of Latvia (hereinafter the Civil Law). The scope of the right to property established in the Satversme is significantly broader compared to the right to property in the civil law meaning of it, and comprises various rights to material values, including the right to claim and meeting of obligations. ${ }^{3}$ Over the years, the Constitutional Court has developed an extensive case law on compliance of legal norms with Article 105 of the Satversme. ${ }^{4}$

One of the judgements, in which the Constitutional Court has expressed findings on the scope and content of the right to property, is in Case No. 2011-19-01 "On Compliance of Para. 4 of Section 6 (2) of Law on the Rights of Landowners to Compensation for Restrictions on Economic Activities in Specially Protected

3 See: Balodis K. Commentary to the Artice 105 of the Satversme. Latvijas Republikas Satversmes komentāri. VIII nodaļa. Cilvēka pamattiesības. Autoru kolektīvs prof. R.Baloža zinātniskā vadībā. Rīga: Latvijas Vēstnesis, 2011, p. 466.

4 See: Balodis K. Īpašuma tiesību ierobežojumu izvērtēšana Satversmes tiesas praksē (Assessment of Restrictions to the Right to Property in the Case Law of the Constitutional Court). Konstitucionālās doktrīnas attīstība Konstitucionālajā tiesā. Satversmes tiesas 2014. gada konferences materiālu krājums. Rīga: Latvijas Republikas Satversmes tiesa, 2014, pp. 135-141. 
Nature Territories and Microreserves with the First Sentence of Article 91 and Article 105 of the Satversme of the Republic of Latvia." In this judgement, the Constitutional Court provided assessment of the scope of the rights of a person acquiring immoveable property. Application to the Constitutional Court in Case No. 2011-19-01 was submitted by the Department of Administrative Cases of the Supreme Court Senate. The applicant in the administrative case was a natural person, who had bought and possessed an agricultural land plot in a rural municipality, but had delayed entering his property into the Land Registry for two years. After the agreement was concluded, but before the title to the property was corroborated in the Land Registry, a microreserve for a protected bird species was established on the land plot. Thus, this person could not claim the compensation for restrictions upon forest management activities, since the contested norm allowed disbursing it only to a person, who had been entered into the Land Registry as the owner.

This judgement is significant also because the majority of Constitutional Court Justices expressed in it an opinion that differed from civil law with regard to the scope of rights of a person, who had bought immoveable property, but had not yet entered it into the Land Register. The Constitutional Court recognised in its judgement, well-foundedly, that compensation for restrictions upon forest management activities fell within the scope of concept "property" referred to in Article 105 of the Satversme. The Constitutional Court also ruled that the contested norm was incompatible with Article 91 of the Satversme, since it failed to ensure equal protection of the right to property established in the Satversme for those persons, who were legal possessors of it, but for various reasons had not corroborated their title to property in the Land Registry.

It must be noted that pursuant to Section 994 of the Civil Law, only a person, who has been entered into the Land Registry as the owner of immoveable property, should be recognised as such. ${ }^{6}$ By concluding a legal transaction, the acquirer of the immoveable property does not yet become the owner of this property neither in the meaning of the Civil Law, nor the Satversme. Upon concluding an agreement on alienation, the landowner only acquires the right of claim vis-à-vis the alienator regarding performance of contract. Since only an entry into the Land Registry establishes public credibility with regard to a particular land plot being in the ownership of a particular person, the State has neither the obligation, nor the possibility to verify, whether this land plot had been in the ownership of the acquirer already before the title to property was

On Compliance of Para. 4 of Section 6 (2) of Law on the Rights of Landowners to Compensation for Restrictions on Economic Activities in Specially Protected Nature Territories and Microreserves with the First Sentence of Article 91 and Article 105 of the Satversme of the Republic of Latvia. Judgement of the Constitutional Court of the Republic of Latvia of 7 June 2012 in Case No. 2011-19-01. Available in English at http://www.satv.tiesa.gov.lv/wp-content/ uploads/2011/11/2011-19-01_Spriedums_ENG.pdf [last viewed August 28, 2016].

6 See more: Grūtups A., Kalniņš E. Commentary to Section 994 of the Civil Law // Civillikuma komentāri. Trešã daḷa. Lietu tiesỉbas. Īpašums. Otrais papildinātais izdevums. Rīga: Tiesu namu aǵentūra, 2002, pp. 124-131. 
corroborated in the Land Registry. ${ }^{7}$ The judgement in Case No. 2011-19-01 does not question the procedure of acquiring the right to property defined in the Civil Law part Property Law. However, the trend seen in this judgement to approximate a person, who has not corroborated the title to property in the Land Registry, to the status of an owner, differs from the civil law understanding of these matters.

In another judgement, the Court examined a public law obligation imposed upon an owner of property by a local government. This is Judgement of 6 November 2014 in Case No. 2013-20-03 "On Compliance of Para. 4.3 and Para. 4.4 of the Binding Regulations of 8 July 2008 of the Riga City Council No. 125 "On Taking Care of Riga City Territory and Maintenance of Buildings" with Article 105 of the Satversme of the Republic of Latvia." The applicant in this case was an owner of a singlefamily house, who, pursuant to the Binding Regulations of the Riga City Council, had to take care of a territory in public use adjacent to his land plot. He held that the obligation imposed by the local government was disproportional.

In addition to private law restrictions upon property established by the Civil Law, an owner must also suffer such restrictions upon property that are defined in public law provisions. The Constitutional Court in its judgement in Case No. 2013-20-03 noted that the fundamental rights enshrined in Article 105 of the Satversme could be restricted not only by narrowing the scope of a person's right to property, but also by imposing upon a person certain property related obligations. Local governments have the right to impose an obligation upon owners to take care and clean the territories in public use that are adjacent to their property. Thus, such obligations that must be performed in public interests also follow from an owner's status.

The Constitutional Court took into account that taking care (cleaning) of territories adjacent to immoveable property was an autonomous function of local governments. If a local government has chosen to impose the performance of its autonomous function upon owners, it must assume co-responsibility in performing this function. Therefore, the Constitutional Court recognised the provisions of the Binding Regulations of the Riga City Council as being incompatible with Article 105 of the Satversme, insofar as the local government did not ensure such participation. Participation by the local government in performing the duty of taking care of adjacent territories is essential, although it may take various forms, for example, technical support or introduction of reliefs. Judgement in Case

Dissenting opinion of Constitutional Court Justice Kaspars Balodis of 21 June 2012 in Case No. 2011-19-01 "On Compliance of Para. 4 of Section 6 (2) of Law on the Rights of Landowners to Compensation for Restrictions on Economic Activities in Specially Protected Nature Territories and Microreserves with the First Sentence of Article 91 and Article 105 of the Satversme of the Republic of Latvia”. Available in Latvian at http://www.satv.tiesa.gov.lv/wp-content/ uploads/2016/02/2011-19-01_Atseviskas_domas.pdf [last viewed August 28, 2016].

8 On Compliance of Para. 4.3 and Para. 4.4 of the Binding Regulations of 8 July 2008 of the Riga City Council No. 125 "On Taking Care of Riga City Territory and Maintenance of Buildings" with Article 105 of the Satversme of the Republic of Latvia. Judgement of the Constitutional Court of the Republic of Latvia of 6 November 2014 in Case No. 2013-20-03. Press-release available in English at http://www.satv.tiesa.gov.lv/en/press-release/the-provisions-in-the-binding-regulationof-riga-city-council-which-define-the-owners-obligation-to-take-care-of-the-territory-adjacent-tohis-or-her-property-insofar-the-legal-regulation-does-not-e/ [last viewed August 28, 2016 ]. 
No. 2013-20-03 is an example of ways for striking a balance between the owner's rights and public interests.

\section{Family law issues in the case law of the Constitutional Court}

Over the years, the Constitutional Court has dealt with a number of significant legal issues regulated by the Civil Law part on family law or otherwise pertaining to family relationships. One among these is the judgement of 27 December 2010 by the Constitutional Court in Case No. 2010-38-01 "On Compliance of Section 358 and Section 364 of the Civil Law with Article 96 of the Satversme of the Republic of Latvia". Article 96 of the Satversme, inter alia, defines everyone's right to inviolability of private life. The aforementioned provisions of the Civil Law part on family law provided that a mentally ill person, to whom a guardian was appointed, was completely deprived of the legal capacity to act. I.e., a mentally ill person placed under guardianship, irrespectively of the level of his or her mental abilities, completely lost the possibility to perform independently legally significant actions. The Constitutional Court noted in its judgement in Case No. 2010-38-01 that a person was deprived of legal capacity with the purpose of protecting the rights of a person with mental health disorders, with the mediation of a guardian ensuring supervision of the matters of this person, and also protecting a person from the consequences of such actions that he was unable to be conscious of and manage. Recognising a person as being legally incapable leaves a significant impact upon his or her ability to act independently and adopt decisions in almost all spheres of life - the person may not conclude agreements, including labour, purchase or lease agreements, may not participate in elections, enter into marriage, draw up a will and perform other activities that would have legal consequences. Thus, recognising a person as being legally incapable restricts his or her rights to private life.

The Constitutional Court also recognised that a person's legal capability should not be restricted more than it was necessary to protect the rights of this person. The restriction should be defined in a way and in scope that would be most favourable and most necessary to the person himself and would include an individual assessment of the situation. The contested norms, which did not envisage any borderline situations and defined only complete deprivation of legal capacity, were incompatible with a person's right to inviolability of private life. Recognising the norms of the Civil Law as being incompatible with Article 96 of the Satversme was the reason, why the Latvian legislator introduced a modern legal regulation, which allowed differentiating the scope of restrictions upon legal capacity of persons with mental or other health disorders.

On Compliance of Section 358 and Section 364 of the Civil Law with Article 96 of the Satversme of the Republic of Latvia. Judgement of the Constitutional Court of the Republic of Latvia of 27 December 2010 in Case No. 2010-38-01. Available in English at http://www.satv.tiesa.gov.lv/ wp-content/uploads/2010/04/2010-38-01_Spriedums_ENG.pdf [last viewed August 29, 2016]. 
Judgement of 16 June 2016 in Case No. 2015-18-01 "On Compliance of Section $5^{1}$ of Maintenance Guarantee Fund Law with Article 96 of the Satversme of the Republic of Latvia" ${ }^{10}$ is one of the recent judgements by the Constitutional Court with significant impact upon family relationships. Pursuant to the contested norm, the administration of the Maintenance Guarantee Fund could publish about debtors of maintenance payments on its home page information, including their name and surname, to facilitate the performance of parents' obligation - making maintenance payments for a child. In this case, the application was not submitted by debtors of maintenance payments, but by the Ombudsman of the Republic of Latvia, who held that the contested norm placed disproportional restrictions upon the right to inviolability of private life.

In this judgement, the Constitutional Court underscored that providing monthly maintenance to a child at least in minimum amount was an obligation that followed from Section 179 of the Civil Law and was not revocable. The judgement recognised that due to application of the contested norm parents had become better at performing their obligation to provide maintenance for their children. The Constitutional Court found that with regard to debtors of maintenance payments the restriction upon fundamental rights could be justified. However, the judgement also concluded that the contested norm was incompatible with Article 96 of the Satversme, since it placed disproportional restrictions upon the rights of a debtor's child to inviolability of private life. The majority of the Constitutional Court held that making information about the debtor public could create a feeling of discomfort in a child, subject him to the risk of abuse by third persons and facilitate social exclusion. Thus, the contested norm was recognised as being incompatible with the Satversme, because making data on the debtor public hypothetically could be adverse for the debtor's child, although the child was the beneficiary and not the addressee of the contested norm.

The dissenting opinion by three Justices of the Constitutional Court regarding judgement in Case No. 2015-18-01 noted, inter alia, that the contested norm pertained to aspects of child-parent relationship, which fell within the framework of private autonomy. Application of the contested norm facilitates ensuring of maintenance payments necessary for the child's development and also that parents perform their duty to maintain the child, which is in the interests of society as a whole. It was underscored in the dissenting opinion that in the case under review the child's right to development was of decisive importance, prevailing over the right

10 On Compliance of Section $5^{1}$ of Maintenance Guarantee Fund Law with Article 96 of the Satversme of the Republic of Latvia. Judgement of the Constitutional Court of the Republic of Latvia of 16 June 2016 in Case No. 2015-18-01. Press-release available in English at http://www.satv.tiesa.gov.lv/en/ press-release/the-norm-on-publishing-the-data-of-debtors-of-maintenance-payments-complieswith-the-satversme-with-regard-to-debtors-fundamental-rights-but-places-disporportionalrestrictions-upon-children/ [last viewed August 29, 2016]. 
to inviolability of private life, and that the contested norm complied with Article 96 of the Satversme. ${ }^{11}$

\section{Legal aspects of employment in the case law of the Constitutional Court}

Fundamental human rights enshrined in Article 106 and Article 107 of the Satversme are closely interconnect both with labour law and legal employment relationships in the broadest meaning thereof. The first sentence of Article 106 provides, inter alia, that everyone has the right to freely choose their employment and workplace in accordance with their abilities and qualification, whereas Article 107 guarantees the rights of all workers to receive a commensurate remuneration for the work done. The Constitutional Court has examined the issue of the right to receive remuneration for work in its decision of 8 November 2012 on terminating legal proceedings in Case No. 2012-04-03 "On Compliance of Para. 6 and Para. 7 of 30 March 2012 Cabinet of Ministers Regulation No. 311 "Provisions Regarding Number of Members of the Board of State or Local Government Capital Companies and Remuneration of a Member of the Council or the Board, a Representative of a Local Government Shareholder and the Chief Employee" with Section 96 (2) of Law On State and Local Government Capital Shares and Companies and Article 107 of the Satversme of the Republic of Latvia". ${ }^{12}$ Pursuant to the contested norms, the chairman and the member of the board of a state or local government capital company have definite monthly salary for working on the board and performing the duties of office within the capital company. In the state capital company, where the applicants were members of the board, positions of President and Vice-president had been established, allowing them to receive remuneration for holding these offices in addition to salary for serving on the board. The contested norms denied the applicants this possibility.

The Constitutional Court recognised that Article 107 of the Satversme applied to legal employment relationship - the relationship that had evolved between the employer and the employee on the basis of an employment contract. Not only

11 Dissenting Opinion of Constitutional Court Justices Kaspars Balodis, Daiga Rezevska and Ineta Ziemele of 17 June 2016 in Case No. 2015-18-01 "On Compliance of Section $5^{1}$ of Maintenance Guarantee Fund Law with Article 96 of the Satversme of the Republic of Latvia". Available in Latvian at http://www.satv.tiesa.gov.lv/wp-content/uploads/2015/07/2015-18-01_Atseviskas_domas.pdf [last viewed August 29, 2016].

12 On Compliance of Para. 6 and Para. 7 of 30 March 2012 Cabinet of Ministers Regulation No. 311 "Provisions Regarding Number of Members of the Board of State or Local Government Capital Companies and Remuneration of a Member of the Council or the Board, a Representative of a Local Government Shareholder and the Chief Employee" with Section 96 (2) of Law On State and Local Government Capital Shares and Companies and Article 107 of the Satversme of the Republic of Latvia. The decision of the Constitutional Court of the Republic of Latvia of 8 November 2012 in Case No. 2012-14-03

Press-release available in English at http://www.satv.tiesa.gov.lv/en/press-release/the-constitutionalcourt-terminates-judicial-proceedings-in-the-case-on-establishing-remuneration-in-state-capitalcompanies/ [last viewed August 30, 2016]. 
employees, but also other natural persons are to be recognised as subjects of the right to remuneration for work. In Case No. 2012-04-03, the Constitutional Court concluded that the applicants' obligations in the council of presidents matched their obligations on the board, for the performance of which they received monthly salaries. The applicants, taking up positions in both institutions, were doing the same work. Therefore, the Constitutional Court terminated legal proceedings in this case. The facts of the Case No. 2012-04-03 are interesting also from the perspective of company law. I.e., it follows from the provisions of the Latvian Commercial Law that a management institution, which duplicates the functions of the board, may not exist alongside the board in a capital company.

Whereas the judgement of 21 December 2015 in Case No. 2015-03-01 "On Compliance of Section 2 of the Law of 25 September 2014 "Amendments to Insolvency Law" and the Law of 30 October 2014 "Amendments to Law on Prevention of Conflict of Interest in Activities of Public Officials" with Article 1 and the First Sentence of Article 106 of the Satversme of the Republic of Latvia"13 assesses granting the status of public officials to administrators of insolvency proceedings. The case was initiated on the basis of applications by administrators of insolvency proceedings, who were also sworn advocates and held that the status of a public official and obligations connected thereto would prohibit them from performing the duties of an advocate. The legislator, with the purpose of improving control over activities of administrators of insolvency proceedings, had turned them into public officials, although the office of the administrator of insolvency proceedings is a position of the private sector, unrelated to performance of public functions.

In this judgement, the Constitutional Court recognised that an element in the right to freely choose one's employment was the right to retain the current employment, which included the right to continue this employment in the future. The right to choose several employments and to exercise them simultaneously also falls within the scope of the right to freely choose one's employment. If this right is restricted with the aim of not allowing combining offices, then that is admissible only on the basis of law and for very important public interests, complying with proportionality. The Constitutional Court also noted that the first sentence in Article 106 of the Satversme did not prohibit the State to set requirements for engaging in a particular employment. Generally, the State can provide that persons, who take certain positions, are public officials. The Constitutional Court, nonetheless, took into consideration the special status of advocates and decided that establishing the status of a public official for administrators of insolvency proceedings was incompatible with the Satversme, to the extent it did not ensure guarantees for professional activities to advocates.

13 On Compliance of Section 2 of the Law of 25 September 2014 "Amendments to Insolvency Law" and the Law of 30 October 2014 "Amendments to Law on Prevention of Conflict of Interest in Activities of Public Officials" with Article 1 and the First Sentence of Article 106 of the Satversme of the Republic of Latvia. Judgement of the Constitutional Court of the Republic of Latvia of 21 December 2015 in Case No. 2015-03-01. Judgement available in English http://www.satv.tiesa. gov.lv/wp-content/uploads/2015/01/2015-03-01_Spriedums_ENG.pdf [last viewed August 30, 2016]. 


\section{Conclusion}

Frequently persons turn to the Constitutional Court because laws or other regulatory enactments that infringe upon their fundamental rights established in the Satversme also hinder these persons from exercising their subjective private rights, for example, the right to property. One of the pre-requites that has to be met so that a person could submit a constitutional complaint to the Constitutional Court is the use of general legal remedies. If the Constitutional Court rules that the legal norm unfavourable to a person is unconstitutional, then the person may turn to a court of general jurisdiction or an administrative court to exercise his or her subjective rights. Often the legal circumstances favourable to a person occurred only because the contested norm had become invalid or the legislator had amended the legal regulation.

A number of rulings of the Constitutional Court comprise findings, explanations and conclusions regarding the place of private law concepts, principles or institutions within the legal system. Thus, the case law of the Constitutional Court with regard to Article 96 of the Satversme allows to conclude that on the constitutional level the principle of private autonomy that dominates in private law is guaranteed by everyone's right to inviolability of private life, established in Article 96 of the Satversme. The case law of the Constitutional Court of the Republic of Latvia is of essential importance not only in the protection of persons' subjective private rights, but also in improving private law or the civil law as a part of the legal system.

\section{BIBLIOGRAPHY}

\section{Literature}

1. Balodis K. Commentary to the Artice 105 of the Satversme. Latvijas Republikas Satversmes komentāri. VIII nodalıa. Cilvēka pamattiesỉbas. Autoru kolektīvs prof. R. Baloža zinātniskā vadībā. Rīga: Latvijas Vēstnesis, 2011, pp. 459-478.

2. Balodis K. Īpašuma tiesỉbu ierobežojumu izvērtēšana Satversmes tiesas praksē (Assessment of Restrictions to the Right to Property in the Case Law of the Constitutional Court) Konstitucionāāas doktrīnas attīstîba Konstitucionālajā tiesā. Satversmes tiesas 2014. gada konferences materiālu kräjums. Rīga: Latvijas Republikas Satversmes tiesa, 2014, pp. 135-141.

3. Grūtups A., Kalninš E. Commentary to Section 994 of the Civil Law. Civillikuma komentāri. Trešã dặa. Lietu tiesības. İpašums. Otrais papildinātais izdevums. Rịga: Tiesu namu aǵentūra, 2002, pp. 124-131.

4. Rodina A., Spale A. Commentary to the Artice 85 of the Satversme. Latvijas Republikas Satversmes komentāri. VI nodalala. Tiesa. VII nodala. Valsts kontrole. Autoru kolektivvs prof. R.Baloža zinātniskā vadībā. Rỉga: Latvijas Vēstnesis, 2013, pp. 119-152.

5. Štarks K. (Starck Ch.). Pamattiesības un privāttiesības: pamattiesību teorija, Vãcijas Pamatlikums un Federālās konstitucionāâas tiesas prakse. Jurista Vãrds, 26.03.2008., No. 12, pp. 14-21. 


\section{Legislative acts}

1. Latvijas Republikas Satversme (The Constitution of the Republic of Latvia). Published by Saeimas Administrācija (the Administration of the Saeima), 2016.

2. Civillikums (The Civil Law of Latvia). Published by Latvijas Vēstnesis, $11^{\text {th }}$ edition, 2016.

3. Satversmes tiesas likums (the Constitutional Court Law of Latvia). Available at http:// likumi.lv/doc.php?id=63354 [last viewed August 28, 2016].

\section{Legal practice}

1. On Compliance of Section 358 and Section 364 of the Civil Law with Article 96 of the Satversme of the Republic of Latvia. Judgement of the Constitutional Court of the Republic of Latvia of 27 December 2010 in Case No. 2010-38-01. Available in English at http://www.satv.tiesa.gov.lv/wp-content/uploads/2010/04/2010-38-01_ Spriedums_ENG.pdf [last viewed August 29, 2016].

2. On Compliance of Para. 4 of Section 6 (2) of Law on the Rights of Landowners to Compensation for Restrictions on Economic Activities in Specially Protected Nature Territories and Microreserves with the First Sentence of Article 91 and Article 105 of the Satversme of the Republic of Latvia. Judgement of the Constitutional Court of the Republic of Latvia of 7 June 2012 in Case No. 2011-19-01. Available in English at http://www.satv.tiesa.gov.lv/wp-content/uploads/2011/11/2011-19-01_Spriedums ENG.pdf [last viewed August 28, 2016].

3. Dissenting opinion of Constitutional Court Justice Kaspars Balodis of 21 June 2012 in Case No. 2011-19-01 "On Compliance of Para. 4 of Section 6 (2) of Law on the Rights of Landowners to Compensation for Restrictions on Economic Activities in Specially Protected Nature Territories and Microreserves with the First Sentence of Article 91 and Article 105 of the Satversme of the Republic of Latvia”. Available in Latvian at http:// www.satv.tiesa.gov.lv/wp-content/uploads/2016/02/2011-19-01_Atseviskas_domas. pdf [last viewed August 28, 2016].

4. On Compliance of Para. 6 and Para. 7 of 30 March 2012 Cabinet of Ministers Regulation No. 311 "Provisions Regarding Number of Members of the Board of State or Local Government Capital Companies and Remuneration of a Member of the Council or the Board, a Representative of a Local Government Shareholder and the Chief Employee" with Section 96 (2) of Law On State and Local Government Capital Shares and Companies and Article 107 of the Satversme of the Republic of Latvia. The decision of the Constitutional Court of the Republic of Latvia of 8 November 2012 in Case No. 2012-14-03. Press-release available in English at http://www.satv.tiesa.gov.lv/en/ press-release/the-constitutional-court-terminates-judicial-proceedings-in-the-case-onestablishing-remuneration-in-state-capital-companies/ [last viewed August 30, 2016].

5. On Compliance of Para. 4.3 and Para. 4.4 of the Binding Regulations of 8 July 2008 of the Riga City Council No. 125 "On Taking Care of Riga City Territory and Maintenance of Buildings" with Article 105 of the Satversme of the Republic of Latvia. Judgement of the Constitutional Court of the Republic of Latvia of 6 November 2014 in Case No. 2013-20-03. Press-release available in English at http://www.satv.tiesa.gov.lv/en/press-release/the-provisions-in-the-bindingregulation-of-riga-city-council-which-define-the-owners-obligation-to-take-care-of-theterritory-adjacent-to-his-or-her-property-insofar-the-legal-regulation-does-not-e/ [last viewed August 28, 2016].

6. On Compliance of Section 2 of the Law of 25 September 2014 "Amendments to Insolvency Law" and the Law of 30 October 2014 "Amendments to Law on Prevention of Conflict of 
Interest in Activities of Public Officials" with Article 1 and the First Sentence of Article 106 of the Satversme of the Republic of Latvia. Judgement of the Constitutional Court of the Republic of Latvia of 21 December 2015 in Case No. 2015-03-01. Judgement available in English http://www.satv.tiesa.gov.lv/wp-content/uploads/2015/01/2015-03-01 Spriedums_ENG.pdf [last viewed August 30, 2016].

7. On Compliance of Section $5^{1}$ of Maintenance Guarantee Fund Law with Article 96 of the Satversme of the Republic of Latvia. Judgement of the Constitutional Court of the Republic of Latvia of 16 June 2016 in Case No. 2015-18-01. Press-release available in English at http:// www.satv.tiesa.gov.lv/en/press-release/the-norm-on-publishing-the-data-of-debtors-ofmaintenance-payments-complies-with-the-satversme-with-regard-to-debtors-fundamentalrights-but-places-disporportional-restrictions-upon-children/ [last viewed August 29, 2016].

8. Dissenting Opinion of Constitutional Court Justices Kaspars Balodis, Daiga Rezevska and Ineta Ziemele of 17 June 2016 in Case No. 2015-18-01 "On Compliance of Section $5^{1}$ of Maintenance Guarantee Fund Law with Article 96 of the Satversme of the Republic of Latvia”. Available in Latvian at http://www.satv.tiesa.gov.lv/wp-content/ uploads/2015/07/2015-18-01_Atseviskas_domas.pdf [last viewed August 29, 2016]. 
Carlo Amatucci, Dr. iur.

University of Naples Federico II, Italy

\title{
LOCAL AUTHORITIES, CREDIT DERIVATIVES AND ART. 117, 119 OF THE ITALIAN CONSTITUTION
}

\begin{abstract}
Summary
Financial derivatives are the most complex instruments conceived by financial engineering. In the past forty years, an increasing number of local governments - on both sides of the Atlantic - entered into derivatives transactions, such as the swap contracts, to lower expected borrowing costs. In the USA, Germany, France, Italy and other EU countries, derivative contracts were written in ways that obscured the underlying economics, generating huge losses, which created large problems in local governments. In Italy, the introduction, during the 1990s, of fiscal austerity and market-oriented reforms, in line with the EMU and the Stability and Growth Pact, and the devolution of fiscal and administrative authority, caused a reduction of fund transfers from the central state to local government level. The process of decentralization granted local authorities a greater autonomy in the administration of their finances and the possibility to use bonds and derivatives. The recurring, inappropriate use of derivatives by banks and intermediaries (for speculative rather than for hedging purposes), the passive role of unsophisticated municipalities - interesting that the Milan Court of Appeal ruled in 2014 to subvert the first degree sentence, which found several managers, officers and banks guilty - and the need to prevent them from postponing the financial burden of debt forward in time, has driven the Italian Parliament to restrict derivative transactions, firstly, limiting the scope only to debt restructuring, and eventually - by prohibiting new transactions to local governments. In the light on the last section of Art. 119 and Art. 117 (lett. e), the Constitutional Court (Decision No. 52/2010) declared that the law was constitutionally legitimate.
\end{abstract}

Keywords: Italian local authorities, credit derivatives, interest rate swaps, complexity, opacity, improper use, Milan derivatives misselling, Italian Stability Law of 2014, Constitutional Court Sentence of 2010, savings and financial markets (Art. 117), power to indebt (Art. 119), risky investment, exclusive competence of central government.

\section{Credit derivatives and local authorities}

Derivatives are contracts between counterparties to take certain actions based on the performance of some other, underlying security. They are complex financial contracts, in which one party pays another party, if 'something' should happen in the future. The "something" that can be quantified and verified, becomes the basis of a derivative contract. In particular, credit derivatives are financial instruments, whose payoffs are linked, in some way, to a change in credit quality of an issuer or issuers. The derivatives market is the world's largest market, but is still relatively regulated. It has grown from virtually nothing two decades ago to the range of $\$ 630$ trillion of notional amount of outstanding contracts in 2014. The largely unregulated credit derivates market has been cited as a cause of the collapse of the housing market 
and resulting credit crunch, which has caused harm to the economy and the lives of millions by destroying trillions of dollars in global wealth. Commentators have judged credit derivatives good or evil: some have praised them for enabling banks to hedge credit risks, while others have warned of hidden dangers and systemic risks. Institutions have both saved and lost fortunes using credit derivatives.

In 2007, Frank Partnoy and David Skeel ${ }^{1}$ noted that until a decade before the transfer and pricing of credit was straightforward. The typical credit relationship was between an individual or corporate manager and the lending officer of a bank, and the typical credit instrument was a loan.

In 2011 Lynn Stout, ${ }^{2}$ investigating the origins of the 2008 financial crisis, defined derivative contracts as probabilistic bets on future events. They can be used to hedge, which reduces risk, but they also provide attractive vehicles for speculation that increases risk. But the hedging inevitably implies complexity. As Stephen Schwarcz ${ }^{3}$ wrote in the wake of the crisis: "Complexity in financial markets does not necessarily arise for complexity's sake, nor from a desire to obfuscate. Rather, it arises in response to demand by investors for securities that meet their investment criteria and their appetite for ever higher yields, in order to facilitate the transfer and trading of risk to those who prefer to hold it, promoting efficiency". And this is one of the main goals of a financial derivative.

Both in the US and Europe ${ }^{4}$ local governments used interest rate swaps to convert interest rate basis from floating to fixed or fixed to floating. An interest rate swap (IRS) is a sophisticated complex financial instrument that only experts with an access to market data and appropriate training and experience can truly understand, price and analyse. It is an agreement between two parties to exchange one stream of interest payments for another over a set period of time.

Local governments were particularly keen on using interest rate swaps to convert interest rate basis to manage liabilities, and (ideally) enable issuers to lower their costs of borrowing. IRS were typically used to optimize the costs by restructuring the debt position. Such debt restructuring aimed to save part of financial resources that were previously used to service debt, therefore generating greater liquidity in a municipal budget.

1 The promise and perils of credit derivatives. Available at http://ssrn.com/abstract=929747 [last viewed October 30, 2015]. Individuals, small businesses, and large public corporations used credit instruments that were virtually identical in form and substance. Today, these practices continue for many individuals and small businesses. But for most public companies, the credit markets are no longer so simple. The typical credit relationship today is between sophisticated risk managers. Companies increasingly turn to hybrid instruments and derivatives in their financings.

2 Derivatives and the legal origins of 2008 credit crisis. Harvard Business Law Review, 2011, Vol. 1, p. 1.

3 Regulating Complexity in Financial Markets, Wash. U. L. Rev. 2009, Vol. 87, p. 211. Schwarcz believes that "Complexity is the greatest challenge to $21^{\text {st }}$ Century financial regulation, having the potential to impair markets and investments in several interrelated ways. [....] Complexity impairs disclosure; it obscures the ability of market participants to see and judge consequences; and it makes financial markets more inclined to financial contagion and also more inclined to fraud".

4 Dodd R., Municipal bombs, Financial \& Development, 2010, p. 33; Geckler P. M., Municipal derivatives use and the suitability doctrine, Wash. U.J. Urb. \& Contemp. L., 1996, v. 49, p. 285. 
Interest rate swaps are traded over the counter. The lack of a formal trading system for these derivatives can increase counterparty risk - essentially, an information failure caused by lack of transparency as to counterparty financial condition.

Many supposedly sound transactions were riskier than local governments believed. Deals usually involved unsophisticated local governments using derivatives traded between two parties, rather than on an organized exchange or through a central clearing counterparty. From the Mediterranean to the Pacific coast of the U.S., officials in government, public agencies, and non-profit institutions lost billions of dollars because of transactions they did not grasp.

In 2013, Harvard University lost 345.3 million USD, terminating interest-rate swaps, bringing its cost of unwinding debt derivatives since 2008 to more than 1.25 billion USD. Jefferson County, Alabama, went bankrupt in 2011 because of interest rate swaps it bought to hedge a portfolio of variable-rate bonds. Swaps and other complex, unregulated derivatives can become what Warren Buffett famously called "financial weapons of mass destruction".

\section{The Italian local authorities}

In Italy, the introduction of fiscal austerity and market-oriented reforms during the 1990s, in line with the EMU and the Stability and Growth Pact, as well as the devolution of fiscal and administrative authority, caused a reduction of fund transfers from the central state to local government level. The process of decentralization granted local authorities a greater autonomy in the administration of their finances and the possibility to use bonds and derivatives. ${ }^{5}$

The use of derivatives by Italian local authorities - regions, provinces and cities dates back to 1994 with the termination - by Law No. 724 of 23 December 1994 of the obligation for them to access to credit through the public body of Cassa Depositi e Prestiti. The law granted provinces and municipalities the right to issue bonds in order to finance their investments. Local authorities were attracted to the interest rate swaps because they saw them as an opportunity to borrow at rates lower than prevailing market rates. They would swap their existing fixed-rate lending for a variable rate with the investment banks. In a period of low rates this meant that local authorities could find their borrowing costs shrunk. However, as interest rates rose, local authorities would find themselves on the losing side of their bet with the banks, as the amount they owed increased.

In other words, hundreds of local governments, which had entered opaque and risky derivatives deals that turned sour, got locked into deals - and future payments - that they had scarcely understood or expected.

The number of local authorities using derivative instruments, almost always interest rate swaps, grew from 349 to 669 between the end of 2005 and the end of

5 Capriglione F., The Use of 'Derivatives' by Italian Local Authorities in Public Finance Management. Still an Issue. Available at https://ssrn.com/abstract=2392709 or http://dx.doi.org/10.2139/ ssrn.2392709 [last viewed March 8, 2017]. 
2007 , before falling to 474 at the end of 2008. At the beginning of 2009 the local entities using them with counterparties operating in Italy numbered 496, including 13 regions, 28 provinces and 440 municipalities. The national value grew rapidly, rising from about 0.1 billion EUR at the end of 2000 to about 33 billion EUR at the end of 2006.

The negative market values, which approximate the amount local authorities would have to pay to the intermediaries, if the outstanding operations closed at the reporting date, grew from about 2 million EUR at the end of 2000 to nearly 1.1 billion EUR in 2009. The largest exposure was that of the municipalities ( 0.6 billion EUR), followed by the regions ( 0.4 billion EUR) and the provinces ( 0.1 billion EUR).

There were three main problems with local governments' use of financial derivatives:

1. The great complexity of the contracts;

2. Their accounting opacity (the future obligations do not appear in the governments' accounts);

3. The possibility of improper use (for instance, to obtain liquidity).

However, the lesson learned in Italy was that many local governments were unable to understand the maths of complex finance risks. The lack of information affecting the local authorities (due to the asymmetries notoriously characterizing the markets' operations) prevented them from acquiring the knowledge necessary to carry out activities qualified by sophisticated technicalities, with the result of performing them in the ways that were not in line with the regulatory provisions adopted to protect the public interest. Furthermore, in those years, the interpretations of the Italian law turned out in a series of violations - the spending power of local governments was virtually unlimited and budget deficits and extra-budget liabilities were generated, which led to the misuse of derivatives for obtaining immediate resources in exchange of larger debt burdens in the future.

Only in 2007 the Stability Law laid down an obligation for local authorities to submit all the underwritten contracts to the Department of Treasury, so that preventive control measures could be taken prior to the conclusion of said contracts.

In 2008, the Stability Law established rules providing the duty of a note to the accounts, in which budget commitments and obligations were reported. For the first time, these operations were entered into the accounts, indicating the markto-market value, the inflows and outflows generated from the transaction date, the projected cash flows for the next three years, and a report on the operation performance.

\section{The Milan derivatives misselling}

The case relates to a swap contract signed by the city of Milan council, when it issued a 1.68 billion EUR, 30-year bond in 2005, in order to restructure previous indebtedness. The city of Milan decided to enter, simultaneously, into a swap transaction with the banks, which acted as arrangers of the bond and as swap counterparties to the swap transactions. The Criminal Court held that the transaction 
did not satisfy the "cost-effectiveness test" required by Art. 41 of the Law of 28 December 2001, No. 448 (the "Art. 41 Test"), which authorised public entities, upon satisfaction of certain conditions, to enter into swap transactions. It took the view that by entering into the swaps the banks had defrauded the city of Milan as they had concluded financial transactions in violation of the principle of good faith. Banks and managers were convicted. The trial was the first of its kind in Italy.

On June 3, 2014, the Appeal Court ${ }^{6}$ upheld the verdict. According to the judges, city employees had been negligent, since they should have arranged an adequate professional structure (even through external resources) able to evaluate the overall consequences of the deal. They should not have completely relied on the information duties of the banks' officers. They could have recruited independent professionals in order to face the negotiations on an equal ground. Instead, the lack of knowledge and competence - inexcusable for a large municipality like Milan -induced to believe that the so-called initial implicit costs were absent, while in reality these costs were hidden and they implied a loss of about 52 million euro. Therefore, the convenience test was negligently erroneous.

The Court of Appeal heavily criticized the inadequacy and the unpreparedness of the City managers and officers. At one point of the 503 pages' sentence, judges wrote that, considering the pecunia publica they were managing, the civil servants should not have relied on the invisible hand of Adam Smith and should have been in no doubt that bank's job is profit making.

Following the case law of the Accounting Courts, the criminal judges passed a sentence that when the local government does not have an internal expertise in financial matters, it has to be counselled by independent and appropriate external consulting.

\section{The civil settlement}

The City of Milan, during the first degree suit, reached a settlement relating to the dispute with the banks. Under the terms of the 455 million EUR settlement deal, the banks would unwind the transactions and pay to the city the current markto-market of the swaps with a substantial discount. In exchange, the city agreed to release certain seized assets and drop claims for damages in the civil suit it had brought. The city also consented to withdraw as a plaintiff in the related criminal suit, although that case was continuing in the court. The banks did not admit any responsibility in connection with their fees as a part of the settlement.

6 Danusso G. M., Il contenzioso sui derivati dopo la sentenza della Corte d'Appello di Milano, Riv. dir. impr., 2015, v. 1, p. 127. 


\section{The Italian Stability Law of 2014 and the end of the story}

The Italian Stability Law of 2014 provided that Italian regions and local authorities:

(a) are permanently prohibited from entering into contracts relating to derivative financial instruments; and

(b) have to place new limits on their recourse to indebtedness.

In particular, they are prohibited from:

(a) entering into contracts relating to derivative financial instruments;

(b) re-negotiating existing derivative contracts;

(c) entering into financing contracts, which include components of derivative.

\section{Conclusions}

Actually, the principle of a deep contrast of Articles 117 and 119 of the Italian Constitution with the local authorities' power of entering in derivative contracts dates back to 2010, when the Constitutional Court ruled on a 2008 Law (d.l. No. 112/2008), which for the first time and temporarily prohibited such option. The Court (decision No. 52/2010 ${ }^{7}$ ) declared that the law was constitutionally legitimate since, according to Art. 117 (lett. e), the central government has an exclusive competence "to protect savings and in matters of financial markets".

The court believed that the policy maker was correct when it temporarily banned the derivatives, considering the highly risky nature of such instruments, whose recourse could not be qualified as "investment" according to Art. 119, which gives local authorities an ordinary power to indebt, but no more than that.

Additionally, the court made clear that financial derivatives expose local authorities to market risks not initially computable and not easy to be forecasted at the time of the closing contract. Therefore, the state regulation aimed at protecting market and public savings, also making safe the finances of local authorities, considered local authorities as the weak part of the deal.

A convincing interpretation of the Italian Constitution which, recognizing implicit and great limits to local authorities (as history confirms based on many critical grounds), opted for a strict exclusion of their power to operate in financial matters.

\section{BIBLIOGRAPHY}

1. Capriglione F., The Use of 'Derivatives' by Italian Local Authorities in Public Finance Management. Still an Issue. Available at https://ssrn.com/abstract=2392709 or http:// dx.doi.org/10.2139/ssrn.2392709 [last viewed October 20, 2015].

2. Judgment of the Italian Constitutional Court, Case No. 52/2010, Giur. it., 2010, 10.

7 Giur. it., 2010, 10. 
3. Danusso G. M., Il contenzioso sui derivati dopo la sentenza della Corte d'Appello di Milano, Riv. dir. impr., 2015, v. 1, p. 127.

4. Dodd R., Municipal bombs, Financial \& Development, 2010, p. 33.

5. Geckler P. M., Municipal derivatives use and the suitability doctrine, Wash. U. J. Urb. \& Contemp. L., 1996, v. 49, p. 285.

6. Partnoy F., Skeel D., The promise and perils of credit derivatives. Available at http://ssrn. com/abstract $=929747$ [last viewed October 30, 2015].

7. Schwarcz S., Regulating Complexity in Financial Markets, Wash. U. L. Rev. 2009, Vol. 87, p. 211.

8. Stout L., Derivatives and the legal origins of 2008 credit crisis, Harvard Business Law Review, 2011, Vol. 1, p. 1. 
Inese Libina-Egnere, Dr. iur.

University of Latvia, Latvia

\title{
PROPERTY RIGHTS, EXPROPRIATION OF REAL ESTATE FOR PUBLIC NEEDS, AND BALANCING OF THE MORTGAGE CREDITOR'S AND REAL ESTATE OWNER'S INTERESTS IN THE PROCESS OF EXPROPRIATION
}

\begin{abstract}
Summary
On 1 June 2016, amendments to the Law "On Expropriation of Real Estate for Public Needs" came into force, resulting in the mortgage creditor involvement procedures being fixed in the expropriation process to provide for informing the creditor about the necessity of expropriation in each case and to involve the creditor in the compensation distribution process.

Articles 105 of the Constitution of the Republic of Latvia provides comprehensive guarantees of property rights, and the content of rights to property includes all financially assessable rights, including the right of pledge. Consequently, in cases when expropriation is in public interest, for the sake of preserving the principle that the owner of the real estate is the main interest protection subject, who has the right to a fair compensation set by the relevant institution, it has to be taken into account that, according to Article 105 of the Constitution of Latvia, the creditor has the right to property secured by public mortgage.
\end{abstract}

Keywords: mortgage creditor, property rights, public needs, expropriation.

\section{Introduction}

On 14 April 2016, the Saeima adopted amendments to the Law "On Expropriation of Real Estate for Public Needs", which came into force on 1 June 2016, by which the mortgage creditor involvement procedures are fixed in the expropriation process, in each case informing the creditor about the necessity of expropriation, as well as the involvement of the creditor in the compensation distribution process.

The aim of the Law "On Expropriation of Real Estate for Public Needs" (hereinafter referred to as the Law) is to establish transparent, effective, and fair procedures for expropriating real estate for public needs ${ }^{1}$.

According to the Law, in cases of both voluntary and coercive expropriation of real estate, the owner of the real estate in question has the right to receive a fair compensation based on identical criteria, thus ensuring equal legal treatment of the owner in both cases. Moreover, it is acknowledged that "the abuse or misuse

Law on the Expropriation of Real Estate for Public Needs. Law of the Republic of Latvia. Latvijas Vēstnesis, 2010, Nr. 174. 
of expropriation power can pose significant risks to land tenure security, human rights, and livelihoods." ${ }^{2}$ Still, if the expropriation is lawful, "most expropriation regimes provide for the compensation of the loss suffered by the holder of the expropriated property rights." ${ }^{3}$ However, in cases where the real estate is subject to mortgage lien, the owner of the real estate is not the only party, whose property rights are affected.

\section{Property rights of mortgage creditor in the process of expropriation of real estate for public needs}

Before the amendments of 1 June 2016, in case of coerced expropriation of real estate, Section 16 of the Law stipulated that, upon corroborating the ownership rights to a real estate in the Land Register, the real estate shall be transferred to the ownership of the state or municipality uninhibited by any encumbrances or burdens arising from any kind of obligations or liabilities (including all liabilities, pledge rights, endorsements regarding the securing of a claim, insolvency endorsements, restrictions imposed by the persons in charge of proceedings, encumbrances accepted upon acquiring the real estate, as well as rent, lease, sustenance and inheritance contracts), which the institution has not explicitly assumed as its own encumbrances or burdens.

According to Section 1278 of the Civil Law, ${ }^{4}$ a pledge right is a right to the property of another person on the basis of which the property secures the claim of a creditor, so that the creditor is able to receive from the property a payment for such claim. Besides, a pledgee, who has not been satisfied by the debtor within the provided time-frame, may resort to the pledged property for satisfaction and, for this purpose, take all the necessary steps for its sale. According to Section 1286 of the Civil Law, a pledge right shall remain in effect until the full satisfaction of the creditor, for whom, after a partial payment is made, the pledge therefore also secures the yet unpaid part of the debt. At the same time, Article 105 of the Constitution of the Republic of Latvia ${ }^{5}$ stipulates that "Everyone has the right to own property. Property shall not be used contrary to the interests of the public. Property rights may be restricted only in accordance with law. Expropriation of property for public purposes shall be allowed only in exceptional cases on the basis of a specific law and in return for fair compensation".

2 Tagliarino N. K. Introduction. Encroaching on Land and Livelihoods: How National Expropriation Laws Measure Up Against International Standards. World Resources Institute, 2016, 6. pp. Available at http://www.wri.org/publication/encroaching-on-land-and-livelihoods [last viewed October 6, 2016].

3 Hoops B. Governance Problem I: Unspecific Expropriation Acts. The Public Purpose Requirement in Expropriation Law: A (Potentially) Rich Source of Safeguards against Arbitrary Expropriation. Washington DC: Paper prepared for presentation at the "2016 World Bank Conference on Land and Poverty", 2016. Available at https://www.conftool.com/landandpoverty2016/index. php?page=browseSessions\&form_session=209 [last viewed October 6, 2016].

4 Civil Law. Part Three. Property Law. Law of the Republic of Latvia. Valdíbas Vēstnesis, 1937, Nr. 44.

5 Constitution of the Republic of Latvia. Latvijas Vēstnesis, 1993, Nr. 43. 
Legal literature argues that the most important property rights protected under Article 105 of the Constitution are the civil property rights covered in Section 927-1129 of the Civil Law. However, Article 105 of the Constitution protects not only the property rights incorporated in the Civil Law, but also other rights and intangible assets. The content of rights to property includes all financially assessable rights, including the right of pledge. ${ }^{6}$ Even the Constitutional Court of the Republic of Latvia has recognised that Article 105 of the Constitution provides for comprehensive guarantees of economic rights which extend beyond property rights. In this context, the concept of "property rights" includes all economic rights which the lawful owner may exercise to their benefit at their own discretion. Therefore, property rights also include the right to enter economically beneficial contracts. Likewise, a variety of claims can be regarded as property, especially claims that can be brought to action based on irrefutable legal grounds. Anticipated income is also deemed to constitute property, given that the income has been already earned or subject to a claim that can be reasonably satisfied. ${ }^{7}$ The Constitutional Court has indicated that "property" may be constituted by either "existing property" or assets, including claims, regarding which property rights can be legally substantiated and acquired by a person. ${ }^{8}$

Thus, in cases of expropriation of real estate for public needs, the property rights of the secured creditor are also guaranteed under Article 105 of the Constitution of the Republic of Latvia, since the property is secured by a public mortgage.

Although expropriation of real estate does not explicitly void the property rights of the mortgage creditor, since the claim rights secured by the pledged real estate remain intact, the former wording of the Law stipulated that the real estate is transferred into the state or municipal ownership free of the right of pledge, while failing to stipulate the procedures for duly informing the mortgage creditor or properly engaging the creditor in the expropriation process, thus limiting the mortgage creditor's

6 Balodis R. Satversmes 105. panta komentārs. Latvijas Republikas Satversmes komentāri: VIII nodaḷa: cilvēka pamattiesības. (Commentaries on the Articles 105. Commentaries on the Constitution of the Republic of Latvia: fundamental rights). Author collective with head of mission Ringolds Balodis (Rìga: Latvijas Vēstnesis, 2011), 466. pp.

7 Judgement of the Constitutional Court of the Republic of Latvia of 13 October 2015 in case No. 2014-36-01 "On the compliance with the Articles 105 of the Constitution of the Republic of Latvia of Section 8.1 of the Law on Control of Aid for Commercial Activity”. Available at: http:// likumi.lv/ta/id/277160-par-komercdarbibas-atbalsta-kontroles-likuma-8-panta-pirmas-dalasatbilstibu-latvijas-republikas-satversmes-105-pantam [last viewed June 9, 2016].

See also: Judgement of the Constitutional Court of the Republic of Latvia of 3 July 2015 in Case No. 2014-12-01 "On the compliance with Article 105 of the Constitution of the Republic of Latvia of Section 3.1, 3.2, 4.1 and 5 of the Subsidised Electricity Tax Law”. Available at http://likumi.lv/ ta/id/275141-par-subsidetas-elektroenergijas-nodokla-likuma-3-panta-1-un-2-punkta-4-panta-1punkta-un-5-panta-atbilstibu-latvijas-republikas [last viewed June 9, 2016].

8 Judgement of the Constitutional Court of the Republic of Latvia of 12 February 2016 in Case No. 2015-13-03 "On the compliance with Article 105 of the Constitution of the Republic of Latvia of the first sentence of Paragraph 24 of binding regulation No. 211 of 19 February 2013 of the Riga City Council "On municipal changes for the use and maintenance of municipal infrastructure in Riga”. Available at http://m.likumi.lv/doc.php?id=280294 [last viewed June 9, 2016]. 
property rights in a way that allows for situations where a mortgage creditor may lose their collateral against which mortgage loan is issued.

\section{Necessity of a new legal regulation}

Whenever only a part of real estate was expropriated, these provisions mostly did not create any problems, since the mortgage creditor was able to retain their collateral on the remaining part of the real estate that remains in the ownership of the original owner. However, in cases where the entire real estate was expropriated either voluntarily or coercively, and where the real estate served as the only collateral, the law did not provide for explicit protection of the mortgage creditor in terms of receiving timely notice about the expropriation process, engagement of the mortgage creditor in the expropriation process, or, in case of voluntary expropriation, procedures for deleting the entry about the right of pledge. ${ }^{9}$

Although the Law did not stipulate the mortgage creditor's involvement in the expropriation of real estate, in practice the institutions in charge of expropriation were open for cooperation and reached out to the mortgage creditor whenever their involvement was deemed necessary. The authors of the draft law indicated that, in cases of voluntary expropriation of real estate, there had not been noteworthy problems in reaching an agreement with the mortgage creditor regarding the deletion of the entry about the right of pledge; however, the protection of the mortgage creditors' interests may become topical in future large-scale projects such as "Rail Baltica". 10

The issue of the necessity for a legal framework to protection of mortgage creditors' interests became urgent during the $11^{\text {th }}$ convocation of the Saeima, when the legislature was working on the draft laws addressing the expropriation of two real estates for public needs - "Novadnieki" and "Cel̦maļi” in Vārve municipality in order to implement a civil aviation runway infrastructure development project of national significance. The relevant mortgage creditor objected to the discharge of encumbrance, but the wording of the Law at the time did not provide for a clear procedure to be adhered to in such situations. Legal provisions solely required the transferable real estate to be free of any encumbrances and burdens. The Legal Affairs Committee of the Saeima then discussed potential approaches to ensure the protection of the mortgage creditor's interests in the specific case of expropriation of real estate. It was proposed that the mortgage be substituted with a financial collateral in the meaning of the Financial Collateral Law or that the involved parties conclude a tripartite escrow agreement. However, both proposals exhibited considerable drawbacks; namely, either the rights of the real estate owner would be disproportionally restricted, or the state or municipal institutions would be

9 Initial Impact Assessment (annotation) of draft law Amendments of the Law on the Expropriation of Real Estate for Public Needs. Available at http://titania.saeima.lv/LIVS12/saeimalivs12.nsf/0/ F11D9E1D58BA9348C2257EE70036DC12?OpenDocument [last viewed June 9, 2016].

10 Ibid. 
excessively interfering with the mutual obligations of two independent parties. ${ }^{11}$ Therefore, the Legal Affairs Committee of the Saeima tasked the Ministry of Justice with elaborating proposals that would offer a universal solution to expropriation of real estate encumbered with mortgage for public good rather than finding ad hoc solutions for each specific case.

It must be pointed out that the Law "On Coercive Expropriation of Real Estate for State or Public Needs", ${ }^{12}$ which regulated the coercive expropriation of real estate up to 2011, when it was substituted with the Law "On Expropriation of Real Estate for Public Needs", included provisions on the involvement of the creditor in coercive expropriation of real estate. For instance, it was stipulated that, in cases where the expropriating institution estimates the value of the relevant real estate as lower than the outstanding mortgage debt, the mortgage creditor shall be included in the appraisal process. Likewise, it provided for the mortgage creditor to take part in the relevant court hearings pertaining to the case in question. Furthermore, it was stipulated that the part of the compensation earmarked for the mortgage creditor shall be payable to the state budget and then transferred to the owner or mortgage creditor upon their request, whereas in cases where the real estate is encumbered with a mortgage debt, which exceeds its appraisal, the creditors are entitled to request the debtor to repay the share of the debt, which remains outstanding because it has not been substituted with a real estate of equivalent value, unless the mortgage contract provides that the debtor's liability shall be limited solely to the pledged real estate.

These regulations, of course, preclude mortgage creditor concerns that their rights may be infringed upon in the process of expropriating real estate for public needs. However, we must bear in mind that, first and foremost, expropriation of real estate for public needs restricts the rights and interests of the owner of the property; that is why the owner is the main entity to be protected within this legislation. The Legal Affairs Committee of the Saeima took into consideration the fact that the previous law did not sufficiently protect the owner of the real estate, as it provided that compensation was issued to the mortgage creditors instead of the real estate owner. Improved protection of the interests of the real estate owner was one of the reasons for drafting the new Law. ${ }^{13}$ The principle that compensation for expropriated real estate is issued to the actual owner may be of paramount importance in cases when the expropriated property is the individual's only place of residence. That is, if the compensation for expropriated real estate were to be issued to the mortgage creditor or paid into an escrow account, thus denying the owner the possibility to use these funds, the individual could be placed in a situation where it is not possible for them to purchase a new place of residence.

11 Audio recording of the 25 September 2013 meeting of the Legal Affairs Committee of the $11^{\text {th }}$ Saeima.

12 For the Expropriation of Property for State and Public needs. Law of the Republic of Latvia. Ziņotājs, 1992, 39. (Lapsed legacy 1 January 2011).

13 Audio recording of the 25 September 2013 meeting of the Legal Affairs Committee of the $11^{\text {th }}$ Saeima. 
For example, the corresponding legislation in Estonia is the Immovables Expropriation Act. Therein, under the Section 20 it is provided that there is a right to transfer a mortgage encumbering an immovable to be expropriated to another immovable in the ownership of the expropriating authority, if the interests of the mortgagee are not harmed in any way. ${ }^{14}$ Secondly, the Section 20 states that, if an immovable to be expropriated is replaced by another immovable by agreement of the parties, the mortgagee has the right to demand the transfer of the mortgage to the replaced immovable. ${ }^{15}$ Furthermore, Section 40 (3) of the Immovables Expropriation Act provides that the creditor has the right to file a claim for payment against the expropriation payment, if the demand for recognition of a claim by the creditor does not exceed six months. ${ }^{16}$

\section{Balancing the interests of the secured creditor and the owner of the real estate in the process of expropriation of real estate for public needs}

The aim of the amendments, which took force on 1 June 2016, was to balance public interests with the interests of the real estate owner and those of the mortgage creditor.

It is crucial that the legislation retains the real estate owner as the main interest protection subject, granting owners the right to the compensation set by the relevant institution, whilst also stipulating that, in cases of expropriation of real estate for public needs, the interests of the person for whom a pledge right has been established are also considered. ${ }^{17}$

The regulations have been drafted so as to minimise their impact on the obligations existing between the owner and the mortgage creditor, including the stipulation that expropriation of real estate for public needs cannot in itself be a reason to demand early settlement of the obligations secured with the relevant property or to deem these obligations as violated. This principle is in line with Section 1320 of the Civil Law, which stipulates that as long as the payment term is not due, a pledgee may not sell the pledge; moreover, if they do sell it, they shall compensate for all losses and expenditures caused to the debtor resulting thereby.

In cases of expropriation of real estate for public needs, the mortgage creditor's interests are respected by two mechanisms: the creditor is informed about the expropriation of the real estate and is involved in the process of distributing the compensation set by the relevant institution.

14 Immovables Expropriation Act. Law of the Republic of Estonia. (1995). Section 20 (1). Available at https://www.riigiteataja.ee/en/eli/504112013002/consolide [last viewed October 6, 2016].

15 Ibid., Section 20 (2).

16 Ibid., Section 40 (3).

17 Law on the Expropriation of Real Estate for Public Needs. Law of the Republic of Latvia. Latvijas Vēstnesis, 2010, 174. Article $7 .^{1}$ 
The Law provides that the notice about the expropriation of real estate for public needs and the compensation set is sent to both the real estate owner and the person for whom the pledge right has been established on the property. Thus, the mortgage creditor is informed from the very beginning of the expropriation process and can therefore take any action necessary for safeguarding their interests. Furthermore, the Law also stipulates that the institution informs the mortgage creditor of having sent the real estate owner a request to conclude a contract on the voluntary expropriation of their real estate. ${ }^{18}$

In regard to the payment of compensation, the Law provides the real estate owner and the mortgage creditor with an option to agree on the distribution of the compensation set by the relevant institution in the case of both voluntary and coercive expropriation of real estate. Such an agreement shall be made known to the institution, indicating the portion of the compensation set by the institution that is to be paid to the real estate owner and the amount payable to the mortgage creditor. In this case, the amount paid to the mortgage creditor shall be used for the early settlement of obligations without changing the settlement conditions, unless both parties have agreed otherwise. ${ }^{19}$ The Law also states that the institution shall pay the compensation by a non-cash transaction; based on an agreement with the real estate owner and if a pledge right has been established on the property, upon the approval of the mortgage creditor, the institution may also offer another real estate property of equal value, or pay a part of the compensation in money and a part - by providing another real estate property. ${ }^{20}$

If the real estate owner and the mortgage creditor are unable to agree on the distribution of the compensation set by the relevant institution, then a portion of the compensation constituting the market value of the real estate is deposited into the deposit account of a sworn bailiff for a term of 3 years with the possibility of withdrawal only in the cases and order stipulated by law. The aim of thus depositing the compensation is to protect the interests of the mortgage creditor by maintaining the mortgage creditor's status and ensuring that the amount deposited in the sworn bailiff's deposit account serves as collateral (substituting the pledge right) should the obligations to the mortgage issuer not be fulfilled. ${ }^{21}$ Since neither the former real estate owner, nor the creditor can unilaterally access the compensation deposited with the bailiff, except in the cases stipulated by law, it was necessary to set a reasonable term, for which the compensation is deposited, so as to motivate the former real estate owner and the mortgage creditor to agree on the distribution of the deposited compensation. At the meetings of the Legal Affairs Committee of

18 Law on the Expropriation of Real Estate for Public Needs. Law of the Republic of Latvia. Latvijas Vēstnesis, 2010, 174. Article 11 part 2. ${ }^{1}$ and Article 18, part 1.

19 Ibid., Article 11 part 4-7.

20 Ibid., Article 12.

${ }^{21}$ Initial Impact Assessment (annotation) of draft law Amendments of the Law on the Expropriation of Real Estate for Public Needs. Available at http://titania.saeima.lv/LIVS12/saeimalivs12.nsf/0/ F11D9E1D58BA9348C2257EE70036DC12? OpenDocument [last viewed June 9, 2016]. 
the Saeima, ${ }^{22}$ the Ministry of Justice advocated for the initial proposal of a 6-year term, mainly focusing on protecting the former real estate owner, because during the deposit period the owners may retain their obligations unaltered, the creditor may not request early settlement, and there is enough time to reach an agreement with the creditor regarding the revision of the obligations. On the other hand, the Legal Bureau of the Saeima pointed out that by setting an extensively long term for the deposit, the state would, in effect, be interfering in the private dealings of natural persons. The Bureau also remarked that the money paid into the sworn bailiff's deposit account is not released for the duration of this period and is therefore not in circulation. It was, furthermore, pointed out that 3 years is a sufficiently long period for solving all disputes, even if they pass through all three instances of court. The representative of sworn bailiffs also expressed the opinion that the depositing of the compensation ought to be only an exceptional measure used in cases when a voluntary agreement as to which party shall receive the compensation cannot be reached. That is why the money needs to be secured for a specific period, giving the parties time to resolve their dispute. In the bailiffs' opinion, the depositing of the compensation does not constitute collection, nor withholding of the funds; rather, they are kept safe until the parties come to an agreement, all the while removing this responsibility from the expropriating institution. The representative of the Association of Latvian Commercial Banks also noted that resolving the issue through negotiations is in the interests of both parties.

Thus, the Law does not preclude the possibility to release the compensation from the bailiff's deposit account prior to the end of the 3-year term. The real estate owner and the mortgage creditor can still agree on the distribution of the compensation set by the relevant institution and inform the sworn bailiff of the agreement reached. The bailiff shall also release the compensation from the deposit account prior to the end of the term based on a document of execution, dividing the compensation according to the order set out in the Civil Procedure Law regarding distribution of funds obtained from the sale of real estate encumbered by a pledge. The Law also regulates cases, when an insolvency procedure has been announced for the former real estate owner. In such a case, the compensation deposited with the sworn bailiff is turned over to the insolvency administrator, who acts in accordance with the Insolvency Law. It is stipulated that the discharge of the pledge right in the cases stated in the Law does not, in itself, affect the insolvency-procedure-related rights of the person for whom the pledge right on the real estate had been established, while this person acts as a secured creditor, according to the principle of preservation of rights enshrined in Section 6 of the Insolvency Law. ${ }^{23}$

At the beginning of the final year of the deposit term, the sworn bailiff shall send to the declared place of residence or the legal address of the former real estate owner and the person for whom the pledge right on the real estate had been established

22 Protocol of the meeting of 30 March 2016 of the Legal Affairs Committee of the $12^{\text {th }}$ Saeima of the Republic of Latvia.

23 Law on the Expropriation of Real Estate for Public Needs. Law of the Republic of Latvia. Latvijas Vēstnesis, 2010, Nr. 174. 
an invitation to agree on the distribution of the compensation and submit a notice thereof. The sworn bailiff also informs them that as of the last year of the deposit term, the legal restriction to request early settlement of the obligations secured by the relevant real estate is lifted for the person for whom the pledge right on the real estate had been established. ${ }^{24}$ The authors of the amendments point out that the aim of this regulation is to strike a fair balance between the interests of the former real estate owner and the mortgage creditor, because the Law provides them with an opportunity to agree on the distribution of the compensation set by the relevant institution, thus ensuring that the future relationship between the two parties is not infringed upon. ${ }^{25}$ However, if the compensation deposited with the bailiff has not been paid out by the end of the 3-year term, then the sworn bailiff shall release the deposited compensation or its remainder to the former real estate owner.

Furthermore, the Law now requires that, upon the corroboration in the Land Register of ownership rights to real estate expropriated on the basis of a contract, the pledge right and corresponding prohibition notice are removed without the consent of the person for whom the pledge right on the real estate had been established. ${ }^{26}$ Thus, the regulation is clarified by laying down that the real estate passes into the state or municipal ownership free of all encumbrances and burdens.

\section{Conclusions}

The Constitution of the Republic of Latvia stipulates that everyone has the right to one's own property. The Constitutional Court of the Republic of Latvia has repeatedly recognised that the concept "of property rights" includes all the economic rights, which the lawful owner may exercise to their benefit at their own discretion. Therefore, property rights also include the right to enter into economically beneficial contracts.

Although expropriation of real estate does not explicitly void the property rights of the mortgage creditor, since the claim rights secured by the pledged real estate remain intact, before the amendments of 1 June 2016, in case of coerced expropriation of real estate, Section 16 of the Law stipulated that the real estate is transferred into the state or municipal ownership free of the right of pledge. However, at the same time, Section 16 failed to define the procedures for duly informing the mortgage creditor or properly engaging the creditor in the expropriation process, limiting

${ }^{24}$ Law on the Expropriation of Real Estate for Public Needs. Law of the Republic of Latvia. Latvijas Vēstnesis, 2010, Nr. 174.

25 Likumprojekta "Grozījumi Sabiedrības vajadzībām nepieciešamā nekustamā īpašuma atsavināšanas likumā” sākotnējās ietekmes novērtējuma ziņojums (anotācija) (Initial Impact Assessment (annotation) of draft law Amendments of the Law on the Expropriation of Real Estate for Public Needs). Available at http://titania.saeima.lv/LIVS12/saeimalivs12.nsf/0/F11D9E1D58BA9348C 2257EE70036DC12?OpenDocument [last viewed June 9, 2016].

26 Sabiedrības vajadzībām nepieciešamā nekustamā īpašuma atsavināšanas likums (Law on the Expropriation of Real Estate for Public Needs). (14 October 2010). Law of the Republic of Latvia. Article 12. ${ }^{1}$ Available at http://likumi.lv/doc.php?id=220517 [last viewed June 9, 2016]. 
the mortgage creditor's property rights in a way that allows for situations, where a mortgage creditor may lose the collateral, against which a mortgage loan was issued. Furthermore, the Law failed to provide a clear procedure outlining the actions in case when, in the process of expropriation, the relevant mortgage creditor objected to the discharge of encumbrance, $-\mathrm{a}$ frequent situation in practice. Therefore, there was a need to create a new legal regulation, which would balance the interests of the secured creditor and the owner of the real estate in the process of expropriation of real estate for public needs.

With the amendments, which entered into force on 1 June 2016, the owner of the real estate remained the main interest protection subject and was granted the right to the compensation set by the relevant institution, whilst also stipulating that the interests of the person for whom a pledge right has been established are also considered.

In cases of expropriation of real estate for public needs, the respect of mortgage creditor's interests are ensured by two mechanisms: the creditor is informed about the expropriation of the real estate and is involved in the process of distributing the compensation set by the relevant institution.

\section{BIBLIOGRAPHY}

\section{Literature}

1. Balodis, K. et al. Satversmes 105. panta komentārs. Latvijas Republikas Satversmes komentāri. VIII nodaļa. Cilvēka pamattiesības. [Comments on Article 105 of the Constitution. Comments on the Constitution of the Republic of Latvia. Chapter VIII. Fundamental Human Rights]. Latvijas Vēstnesis, 2011, 466.

2. Hoops B. Governance Problem I: Unspecific Expropriation Acts. The Public Purpose Requirement in Expropriation Law: A (Potentially) Rich Source of Safeguards against Arbitrary Expropriation. Washington DC: Paper prepared for presentation at the "2016 World Bank Confference on Land and Poverty", 2016. Available at https://www.conftool.com/ landandpoverty2016/index.php?page=browseSessions\&form_session $=209 \quad[$ last viewed October 6, 2016].

3. Tagliarino N. K. Encroaching on Land and Livelihoods: How National Expropriation Laws Measure Up Against International Standards. World Resources Institute, 2016.

\section{Legislative acts}

1. Constitution of the Republic of Latvia. Latvijas Vēstnesis, Nr. 43, 1993.

2. Civil Law. Part Three. Property Law. Law of the Republic of Latvia. 1937. Valdības Vēstnesis, Nr. 44, 1937.

3. Law on the Expropriation of Real Estate for Public Needs. Law of the Republic of Latvia. Latvijas Vēstnesis, Nr. 174, 2010.

4. Immovables Expropriation Act. Law of the Republic of Estonia. 1995. Available at https:// www.riigiteataja.ee/en/eli/504112013002/consolide [last viewed October 6, 2016]. 


\section{Legal practice}

1. Judgement of the Constitutional Court of the Republic of Latvia of 12 February 2016 in Case No. 2015-13-03 "On the compliance with Article 105 of the Constitution of the Republic of Latvia of the first sentence of Paragraph 24 of binding regulation No. 211 of 19 February 2013 of the Riga City Council "On municipal charges for the use and maintenance of municipal infrastructure in Riga”.

2. Judgement of the Constitutional Court of the Republic of Latvia of 13 October 2015 in Case No. 2014-36-01 "On the compliance with Article 105 of the Constitution of the Republic of Latvia of Section 8.1 of the Law on Control of Aid for Commercial Activity".

3. Judgement of the Constitutional Court of the Republic of Latvia of 3 July 2015 in case No. 2014-12-01 "On the compliance with Article 105 of the Constitution of the Republic of Latvia of Section 3.1, 3.2, 4.1 and 5 of the Subsidised Electricity Tax Law".

\section{Other sources}

1. Initial Impact Assessment (annotation) of draft law Amendments to the Law on the Expropriation of Real Estate for Public Needs.

2. Protocol of the meeting of 30 March 2016 of the Legal Affairs Committee of the $12^{\text {th }}$ Saeima of the Republic of Latvia.

3. Audio recording of the 25 September 2013 meeting of the Legal Affairs Committee of the $11^{\text {th }}$ Saeima. 
Eduardo Zampella, Dr. iur.

University of Naples Federico II, Italy

\title{
OVER-INDEBTEDNESS CRISES SETTLEMENT AGREEMENTS AND THE CONSTITUTIONAL PROTECTION OF THE RIGHTS OF CITIZENS AND BUSINESS ENTERPRISES IN ITALY
}

\begin{abstract}
Summary
The paper aims to illustrate in broad lines a new legal instrument of over-indebtedness crisis settlement agreements, which was introduced in 2012 and further amended several times, since it does not only affect business entrepreneurs, but also non-fallible entrepreneurs who are not subject to failure, the so-called "sub-threshold" entrepreneurs, like farmers, professionals and consumers. All these subjects have multiple economic relationships. The Italian Constitution protects the freedom of economic initiatives of both private citizens and entrepreneurs. However, the economic crises of entrepreneurs and private citizens are differently regulated compared to bankruptcy and an individual forced execution.

Law No. 3, 27 June 2012, and the draft of a Delegated Law on business crises, following Commission Recommendation 2014/135/EU, 12 March 2014 on a new approach to business failure and insolvency and EU Regulation No. 2015/848, 20 May 2015 on cross-border insolvency proceedings of the EU Commission, add to the traditional legal instrument of bankruptcy three new procedures which are applicable to no-bankruptcy subjects, whether they be entrepreneurs or not.

The Delegated Law will introduce a comprehensive reform of bankruptcy and other proceedings. However, it will still take a long way and thus it will only be mentioned in this paper.

Law No. 3/2012 introduces a new concept of "over-indebtedness", which is a necessary prerequisite for both an entrepreneur and a non-entrepreneur to be admitted to insolvency proceedings that are distinct from the "state of insolvency", such as an entrepreneur's inability to fulfil his or her obligations.

In the light of these principles, the current discipline of "over-indebtedness crisis settlement agreement", which was introduced for non-entrepreneurs by Law No. 3/2012 and amended several times, is illustrated in broad lines to shed light on some problematic related issues.
\end{abstract}

Keywords: settlement of over-indebtedness crisis, over-indebtedness crisis settlement agreements, Crisis Settlement Body, Rordorf Ministerial Commission, constitutional protection of the rights of citizens and business enterprises.

\section{New regulatory frontiers}

The 2008 financial crisis expanded from the U.S.A. to Italy and Europe and became a global crisis. As a result, new legal instruments appeared necessary to face the crisis, since the traditional legal instruments of bankruptcy and other insolvency 
proceedings, ${ }^{1}$ based on the traditional legal concept of insolvency, appeared to be increasingly inadequate.

Innovative legal institutions were rapidly introduced in the U.S.A. followed by regulations surpassing and limiting the traditional notion of insolvency in France, Germany, Great Britain, Spain and other EU countries. Italy also faced the need to overcome the financial crisis and by Law No. 3, 27 January 2012 introduced an overindebtedness crisis settlement procedure with new principles and a new discipline.

The EU, which directs and encourages the Member States to introduce a new approach to business failure and insolvency, has enacted Recommendation No. 2014/135/EU, 12 March 2014, ${ }^{2}$ and Regulation (EU) No. 2015/848, 20 May 2015, on cross-border insolvency proceedings. ${ }^{3}$

\section{Over-indebtedness crisis settlement}

The creditor of a no-bankruptcy entrepreneur, like a professional or consumer, who is not subject to bankruptcy, was allowed to act only by instigating an individual executive action for the satisfaction of his or her own credit. The legislator has added, to the procedures disciplined by the Bankruptcy Law for the business entrepreneur, an over-indebtedness crisis settlement procedure for the "civil" debtor. This new legal instrument surpasses and replaces the traditional instrument of an individual executive action, and pursues the goal of "discharge", that is, liberation from the entire outstanding debt.

The concept of "over-indebtedness" is completely new in Italy and represents the overcoming of the classical notion of insolvency. Over-indebtedness and Insolvency are two different notions. Over-indebtedness is defined by Law No. 3/2012, Article 6, paragraph 2 a), amended by Decree Law No. 179/2012, as a "situation of persistent imbalance between the obligations assumed and liquid assets to meet them, which determines the major difficulties to fulfil obligations, or the incapacity to perform them regularly". Insolvency, instead, is defined by Royal Decree No. 267, 19 March 1942, Article 5, paragraph 2, (the so-called Bankruptcy Law), as a series of "failures or other external circumstances, which demonstrate that the debtor is no longer able to regularly meet his or her own obligations". The notion of "discharge" has been introduced with the reform of Bankruptcy Law 2006, Art. 142, in order to enable the commercial entrepreneur to resume his or her business. This, however, is an absolutely new concept for a no-bankruptcy entrepreneur and a nonentrepreneur which allows a debtor to free himself or herself of all previous debts and start from zero again (the so-called "fresh start"). The subjects who can use the new procedure are entrepreneurs that are not subject to bankruptcy, professionals, consumers, and anyone who is in a serious debt crisis and is no longer able to fulfil his or her own obligations.

Royal Decree No. 262, 16 March 1942, amended by Legislative Decree No. 5, 9 January, 2006.

Official Journal of the European Union, 57 (L 74), 2014.

Official Journal of the European Union, 58 (L 141), 2015. 
It is a new, mixed insolvency procedure, whose characteristics can be identified, as follows: 1) it starts with the debtor's initiative; 2) it requires an obligatory intervention of the Crisis Settlement Body; 3) it is subject to control and validation of the competent Court. This procedure is similar to arrangements with creditors and debt-restructuring agreements, regulated by Article 160 et seq. and Article 182-bis of the Bankruptcy Law, but is more streamlined and rapid as concerns its performance.

\section{Law No. 3, 27 January 2012, and further modifications}

The rulemaking process has been very troublesome. As a matter of fact, the original Decree Law, No. 212, 22.12.2011, did not become Law; the following Law, No. 3, 27.01.2012, has been repeatedly amended by Decree Law No. 179 "Growth Decree-bis", 18.10.2012, converted into Law No. 221/2012, and by Decree Law No. 83, 27.06.2015, converted into Law No. 132, 08.08.2015. Currently, Draft Law No. 3671-bis, which delegates the Government to implement the reform of the disciplines of business failure crisis and insolvency, has been drafted by the Rordorf Commission and passed by the Council of Ministers on 14.01.2016 (the so-called Delegated Rordorf Law), and is currently under examination of the Parliamentary Committees and the Parliament.

Law No. 3, 27 January 2012, with its further modifications, introduces three new procedures:

1) Over-indebtedness crisis settlement agreements, regulated by Articles 6 to 12,13 and 14, which are accessed through a plan proposed by the debtor and accepted by $60 \%$ of the creditors.

2) The Consumers' plan, regulated by Articles 6 to8, 12-bis and 12-ter, 13, 14-bis, for non-guilty or non-culpable consumers who present a plan prepared by the debtor. The Consumers' plan does not require the creditors' approval and is validated by the Court.

3) The assets liquidation process, regulated by Articles 14-ter et seq., implements a compulsory liquidation of all the debtor's assets through a simplified procedure.

The first two procedures allow taking assets whole or in part; the third one, instead, ensures the liquidation of assets. This paper only focuses on the first procedure.

\section{Constitutional protection and adaptation to the Constitutional principles}

The new procedure is a further implementation of the Constitutional principle of equality of citizens expressed in Article 3 of the Italian Constitution "All citizens have equal social dignity and are equal before the law", thus granting to non-entrepreneurs and entrepreneurs not subject to bankruptcy a legal instrument to face the state of crisis, just like business entrepreneurs can rely on an arrangement with their 
creditors and a debt-restructuring agreement. The new procedure also represents an adjustment and favors a broader application of the Constitutional principle of freedom of economic, individual, professional and business enterprise, expressed in Article 41, paragraph 1 of the Italian Constitution "Private economic enterprise is free", and paragraph 3 "The law shall provide the appropriate programs and controls so that ... it may be directed and coordinated towards social ends", which finds its realization and juridical guardianship in the Civil Code, in the disciplines of freedom of contract and freedom of enterprise. ${ }^{4}$

\section{The Ministerial Commission, the so-called Rordorf Commission}

The Ministerial Commission, chaired by Professor Rordorf, appointed by Ministerial Decree No. 28/01/2015, has drafted the first and the second version and then a Delegated Law bill for the reform of insolvency proceedings, approved by the Council of Ministers on 01.11.2016, submitted to the Italian Parliament and currently under the examination of the Justice Commission of the Chamber of Deputies. The deadline for submitting amendments was 21.11.2016. The Parliamentary approval, which was due within October 2016, still seems a long way ahead. Because of an uncertain future for this legislative text, the numerous and substantial changes to this legal instrument, which might be introduced with the Parliamentary approval of the Delegated Law and subsequent enactment of the Delegated Decrees, are not discussed in this paper. At present, in fact, apart from only a few semi-official drafts and a Delegated Law Scheme approved by the Cabinet, there is no single coherent document. Thus, we prefer not to discuss mere hypotheses hoping that the Italian Parliament will complete its work into a comprehensive law that may be applicable in all insolvency proceedings.

\section{Over-indebtedness crisis and a procedure of over-indebtedness crisis settlement agreements}

No-bankruptcy entrepreneurs, like farmers, ${ }^{5}$ professionals, consumers and any other debtor that is not subject to other insolvency proceedings can access this procedure. ${ }^{6}$ The business activity continues to be practiced and the assets are kept on the whole or in part. It can only be instigated by the debtor, nor as an initiative of the creditors or of the Court, i.e. ex officio. It is currently regulated by Law No. 3, 28.01.2012, as amended by Decree Law No. 179, 18.10.2012, converted into Law No. 221/2012 and Decree Law No. 83, 27.06.2015, converted into Law No. 132, 08.08.2015. It appears to be modelled on the scheme of the deal with creditors, recently reformed,

Civil Code, Art. 1322 and Art. 2082.

5 With Article 7, paragraph 2-bis, introduced later, by Decree Law No. 179, 18.10.2012, converted into Law No. 221, 17.12.2013, Art. 18, paragraph 1, letter e), No. 2, the procedure has been expressly extended to farmers.

6 The same applies to another procedure, the Consumers' Plan. 
Art. 160 et seq., and on the debt-restructuring agreements, recently introduced by the reform of the Bankruptcy Law, Art. 182-bis. There are many analogies, especially with the deal with creditors on specific points of the procedure. ${ }^{7}$ It seems that the legislator has intended to provide a no-bankruptcy debtor with the same opportunities for debt resolution and economic recovery as previously offered only to a commercial entrepreneur. ${ }^{8}$

The long and minutely articulated procedure, which is currently in force, is briefly illustrated here without tackling the numerous issues that concern specific points in it. The objective condition is the state of "over-indebtedness" of a non-fallible debtor (Art. 6, paragraph 2, letter a), Law No. 3/2012, modified by Decree Law No. 179/2012), namely, the debtor's assets' situation, which may consist either in a state of insolvency, as an incapacity to regularly and normally fulfil one's own duty, or in a financial crisis, as significant difficulties to fulfil one's own obligations. The subjective condition is that the debtor would not be subject to bankruptcy or other insolvency proceedings. Only the debtor, not the creditors nor the Court ex officio, may propose to the Court a demand for the resolution of the crisis, through recourse to a specific Crisis Settlement Body and only once every five years.

\section{Over-indebtedness crisis settlement agreement}

The including a farmer in a condition of over-indebtedness, who is not subject to other insolvency procedures (Art. 7, paragraph 2-bis), as well as a "sub-threshold" commercial entrepreneur, a professional, a "consumer", who has assumed obligations exclusively for purposes unrelated to business or professional activities, drafts an agreement proposal as a form of debtrestructuring and satisfaction of the creditors. It is a benefit granted to "civil" debtors, which leads to their discharge, allowing them to permanently and completely free themselves of all residual economic commitments. The proposal has an ample content, reduced or deferred payment of debts or a transfer of the assets to a manager, who sells them and distributes the profit to the creditors. The proposed agreement may take the form of: remission agreement, when the creditors give up part of their claims; dilatory agreement in payments; mixed agreement with elements of the previous ones; agreement of assignment of future credits; agreement of the creditors' division into classes, each with a differentiated treatment. The debtor, regardless of the type of the proposal, retains full access to his or her assets. The proposed agreement contains the mode of payment, deadlines, reference to any compliance guarantees. ${ }^{9}$

Campobasso G. F. Diritto commerciale. III, Series $5^{\text {nd }}$ edition. Torino, UTET, 2014, p. 479, et seq.

8 Pisani Massamorile A. (ed.). La crisi del soggetto non fallibile. Torino. G. Giappichelli, 2016. p. 158, et seq. This source analyzes single aspects and similarities among the crisis caused by overindebtedness, the deal with the creditors and the debt-restructuring agreement, which can be useful for a more detailed study.

9 Giorgi V. Misure per facilitare la gestione delle crisi aziendali ed accordi di ristrutturazione del debito. In: Le Nuove Leggi Civile Commentate. Padova. CEDAM, 2013, p. 1205 et seq. 
Undistrainable credits, (i.e. food, salaries, severance indemnities, etc.), are excluded from the proposal. They must be paid in full and the credits provided with privilege, pledge or mortgage must be satisfied according to the general rules regulating the goods or the rights upon which a hearing of pre-emption is initiated. If the proposal provides for the continuation of the activity of an enterprise, an extension up to one year from the moment of such claims' approval (Art. 8, paragraph 4 ) is also offered to the non-entrepreneur, the professional or the consumer. It is not possible to propose a reduction of payment but only a delay (Articles 7, paragraph 1 ), for fees payable to the EU, VAT and unpaid withholding taxes. The proposal for an agreement is not submitted by the debtor, but by the Crisis Settlement Body, which evaluates the plan, ascertaining its feasibility, verifying the veracity of the proposed data and attachments, and ensuring its implementation after approval. Crisis Settlement Bodies may be established by the public sector entities fulfilling the necessary independence and qualification requirements (Art. 15). The proposal must be deposited with a competent Court (Art. 9) and a copy must be submitted to financial offices. If the debtor's income and assets are not sufficient, other incomes or assets can be given as a guarantee by third parties, who must sign the proposal together with the debtor, who may also be a "consumer"10 (Art. 8, paragraph 2), thereby becoming a party to the agreement. The proposal to the Crisis Settlement Body must be accompanied by the declaration on the feasibility of the plan and appropriate documentation.

The proposal cannot be submitted if the debtor: 1) has instigated a procedure of crisis resolution or liquidation of assets within the previous five years; 2) when the debtor has undergone, for reasons attributable to him, a measure of cancellation or resolution of a previous crisis settlement agreement or revocation, or termination of the effects of a previous plan of the consumer; 3 ) when the debtor has provided insufficient documentation to verify his or her economic and financial situation (Art. 7, paragraph 2).

The Single Judge Court alone and with a proceeding in the Council Chamber (Article 10, paragraph 6) ${ }^{11} 11$ carries out a preliminary examination of the application to verify the existence of the admissibility requirements, completeness of the documentation and compliance of the content of the proposal with the legal requirements. If it establishes any irregularities, a peremptory deadline may be granted not exceeding fifteen days to amend the proposal and submit new documents. At this first stage, the Court cannot enter into the convenience of the Agreement, but only exert a legal control. An assessment of the Agreement is possible only when a number of creditors have disputed its validation. Conversely, the Court cannot but endorse the detailed report of the Crisis Settlement Body on the "supposed convenience" of the proposal.

10 "Consumer", as defined by the Articles 6, paragraph 2, letter. b), is anyone for whose benefit a specific procedure, the Consumers' Plan, has been introduced, with the first amendments to the Law No. 3/2012. In order to approve the Consumer's Plan, approval of the creditors is not necessary, only validation of the Court is required.

11 Full exposure and analytical procedure is contained in Campobasso G. F., Diritto commerciale. III, cit. pp. 479-486. Reference should be made to it for a more detailed study. 
Once this preliminary examination has been completed, the Court opens the procedure with a decree, or rejects the application. Both Proposal and Decree are subject to publication according to the forms established by the Court and recorded in the Commercial Register, if the debtor is an entrepreneur. They are also transcribed in securities and real estate registers, if transfer of the goods to the third parties is admitted (Art.10, paragraph 2).

The doctrine has raised the problem of the nature of the agreement. Article 11, paragraph 4, states that the agreement "does not cause novation of obligations, unless otherwise provided." The text is consistent with Article. 1230, paragraph 2, of the Civil Code in terms of obligations. If it is the will of the parties to determine the novation, one can easily deduce its nature as of a private law agreement, determined by the meeting of the will of the proposer-debtor and his or her creditors. ${ }^{12}$

\section{Effects and execution of the agreement}

Starting from the opening of the procedure and until its approval, the same effects as those of pre-emption arrangements are achieved, at least in part, for the debtor and the creditors (Art. 160 et seq. of Bankruptcy Law), as expressly referred to by law.

In the haste of legislature, there is no reference to any other effects of the arrangement. However, the corresponding discipline of Articles 55-64 of the Bankruptcy Law could be applied by analogy where compatible to those not referred to. ${ }^{13}$ The debtor may dispose of its assets only to implement the acts of ordinary administration; meanwhile, for the acts of extraordinary administration he or she must request the authorization of the Court, under the penalty of ineffectiveness (Art. 10, paragraph 3-bis).

Insolvency creditors may not, under the penalty of nullity, start or continue individual enforcement actions, except for the holders of the undistrainable credits, conservative seizure, purchase the rights on the assets of the proponent. Prescription and decline are suspended (Art. 10, paragraph 2, letter C, and paragraph 4), as well as, conventional and legal interests, except for privileged credits or the ones guaranteed by pledge or mortgage (Art. 14-ter, paragraph 7). The Decree of opening the procedure is equalled by the attachment placed on the goods - object of the plan, in favor of the insolvency creditors (Art. 10, paragraph 5). The credits taken during the course of the crisis settlement procedure are considered pre-deductible and are satisfied in preference to others. (Art. 13, paragraph 4-bis). Creditors with posterior titles are regarded as insolvency creditors and cannot attack the assets of the debtor for the entire course of the procedure (Art. 12, paragraph 3).

12 Cerri F., Contenuto della proposta e del piano del consumatore, from Di Marzio F., Macario F., Terrabova G. (eds.). La nuova composizione della crisi da sovraindebitamento, Milano, 2013, p. 407.

13 Pisani Massamormile A., op. cit., p. 160. 


\section{Approval, validation and execution}

The Court, with the opening Decree, fixes the hearing in order to verify whether the agreement has been reached. The Crisis Settlement Body informs every creditor about it (Art. 10, paragraph 1)..$^{14}$ The creditors may send a statement of consent to the proposal to the Crisis Settlement Body up to ten days before the hearing. Failing that date, tacit consent is presumed to exist (Art. 11, paragraph 1, as amended by Decree Law No. 179/2012). Thus, the creditor's silence regarding the proposal is equivalent to its acceptance, as in the arrangements with creditors. The hearing, according to Art. 10, paragraph 3, confers an autonomous power of intervention upon the Court, unlikely from the case concerning the admissibility of the proposal, only if it recognizes "initiatives or acts in fraud of creditors", revoking the admission decree regarding the case. ${ }^{15}$ Outside of this hypothetical situation, it appears that the Court has no direct power to influence the process and the agreement. The agreement may be amended when the execution has become impossible for the reasons not attributable to the debtor; the debtor may propose, through the Crisis Settlement Body, a modification of the original plan, which has the value of a newly proposed agreement.

The agreement is considered approved by the creditors representing at least sixty percent of the credits, regardless of any division of the creditors into classes (Art. 11, paragraph 2). The categories of the creditors who are excluded from voting in the arrangements with creditors have no right to vote. If the required majority of the creditors has approved the agreement, the stage of validation is opened and held before a competent Court. The Crisis Settlement Body prepares a specific report and sends it, together with the text of the agreement, to the creditors, who may raise objections within ten days. Then, the Crisis Settlement Body sends the report, with any objections and the final certification on the feasibility of the plan to the Court (Art. 12, paragraph 1).

The Court verifies the achievement of the majority, the suitability of the plan to ensure full payment of the undistrainable credits, VAT, EU, Withholding tax, the existence of the eligibility requirements already verified, the regularity of the proceedings, and approves the agreement, without considering the convenience of the agreement for the creditors, unless there are any objections by dissenting creditors. However, the Court can also approve the agreement, if it considers the agreement more convenient for the liquidation of the assets. The approval suspends

individual enforcement actions.

The Approval Decree must be taken within six months and is subject to publication, as well as the Decree of Admission. The approved agreement is mandatory for all insolvency creditors, that is to say, prior to the time the Decree of Admission was published (Art. 12, paragraph 3). The agreement does not prejudice the rights of

${ }^{14}$ For a detailed study of the procedural stages, consult please: Guglielmucci, L. Diritto fallimentare. Series $6^{\text {th }}$ edition. Torino, Giappichelli G., 2014, p. 407 et seq.

15 Cerri F. op. cit., 29. 
creditors against joint debtors, guarantors and obligors in an order of regress, in respect to whom the benefit of discharge is not applied.

The approved agreement is then executed by the debtor, who performs the prescribed payments or, if assets are to be sold, this is carried out by a judicial liquidator appointed by the Court, or by the Crisis Settlement Body. The Court may suspend the enforcement acts of the agreement in the presence of serious reasons (Articles 13, paragraph 3). Holders of undistrainable credits are entitled to a full payment.

\section{Revocation, cancellation, termination}

This aspect is only briefly mentioned to ensure completeness of the review. ${ }^{16}$ The agreement may be revoked even ex officio when it is apparent that the acts committed are directed to deceive the creditors (Art. 11, paragraph 5). The agreement can be cancelled on request of each creditor, by an appeal lodged within six months since the discovery of the facts and not more than two years since the last instance, when the debtor has wilfully or with gross negligence, increased or reduced the passive, withdrawn or disguised a significant part of the business activities or wilfully simulated nonexistent activities. No other grounds for cancellation are admitted (Art. 14, paragraph 1).

The agreement may be rescinded by law 1) when the debtor does not, within ninety days from the due date, fully complete the stipulated payments due to public authorities and social security bodies (Art. 11, paragraph 5); 2) for non-payment of undistrainable credits, EU taxes, VAT, Withholding taxes, with regard to which it is not allowed to propose a partial fulfilment, ascertained by the Court (Art. 12, paragraph 4$) ; 3$ ) when the declaration of failure of the proponent debtor intervenes (Art. 12, comma 5)..$^{17}$

Another reason for the agreement revocation, i.e. ex officio, already mentioned, is when it is apparent that the committed acts were intended to deceive the creditors, even before the homologation (Art. 11, paragraph 5). The judicial resolution is disposed by the Court upon request of a creditor, in case of a failure to carry out the obligations assumed with the agreement, or if the promised guarantees were not constituted (Art 14, paragraph 2).

\section{Conclusions}

This is a brief illustration of current over-indebtedness crises settlement agreements and the regulation, currently in force, characterized by a complex and cumbersome procedural process that actually makes the new legal instrument expensive and difficult to apply. The Public bill contains numerous and significant changes to streamline the jumbled system and make it more transparent. However, the period

16 Campobasso G. F., op. cit., p. 482 et seq.

17 Guglielmucci L. op. cit., p. 409. 
for the approval of such a complex reform of the insolvency proceedings appears to be still long and uncertain.

Looking forward to a new and organic legislation based on unitary principles and concepts for all types of insolvency proceedings, we envisage a general and extensive simplification of the current framework, a redefinition of the assumptions of discharge, a reduction of the costs, which are significant today, which would make the procedure effectively applicable to all debtors, non-fallible entrepreneurs, nonentrepreneurs, professionals, consumers, with a real adequacy to a current global economic system and European regulation, similar to the legislation already in force in many other countries.

The guiding principles of the newly introduced legal instruments, however, remain valid and innovative in the solutions adopted, which should be improved and harmonized with further European legislation. Nonetheless, they still have the worth of considering human and social aspects, and not solely entrepreneurial aspects in solving crises, and of focusing on the individual's reasons rather than only upon those of the creditors.

\section{BIBLIOGRAPHY}

\section{Literature}

1. Campobasso G. F. Diritto Commerciale, $5^{\text {th }}$ edition. Torino. UTET, 2014.

2. Cerri F. Contenuto della proposta e del piano del consumatore. La "nuova" composizione della crisi da sovraindebitamento, Di Marzio F., Macario F., Terranova G. (eds.). Milano, 2013.

3. Giorgi V. Misure per facilitare la gestione delle crisi aziendali ed accordi di ristrutturazione del debito. Le Nuove Leggi Civile Commentate. Padova. CEDAM, 2013, p. 1201 et seq.

4. Di Marzio F., Macario F., Terranova G. (eds.). La "nuova" composizione della crisi da sovraindebitamento, Milano, 2013.

5. Guglielmucci L. Diritto fallimentare. $6^{\text {th }}$ edition. Torino. Giappichelli, 2014.

6. Pisani Massamormile A. (ed.). La crisi del soggetto non fallibile. Torino, Giappichelli, 2016.

\section{Legislative acts}

1. Regulation (EU) 2015/848 of the European Parliament and of the Council of 20 May 2015 on insolvency proceedings. Official Journal of the European Union, 58 (L 141), 2015.

\section{Other sources}

1. Commission Recommendation n. 2014/135/EU of 12 March 2014 on a new approach to business failure and insolvency. Official Journal of the European Union, 57 (L 74), 2014.

2. Commissione Ministeriale, Report and outline of the Bill No. 3671 - bis Delega al Governo per la riforma delle discipline della crisi di impresa e dell'insolvenza" (Commissione Rordorf), approved by the Council of Ministers 14.01.2016 (so-called Delegated Law Rordorf), Roma, 2016. 


\section{SECTION 5}

\section{INTERACTION BETWEEN INTERNATIONAL LAW AND CONSTITUTIONAL VALUES}


Klara Drlickova, Dr. iur.

Masaryk University, Czech Republic

\title{
PUBLIC POLICY UNDER \\ THE ARTICLE V(2)(B) OF THE NEW YORK CONVENTION AS AN INSTRUMENT PROTECTING CONSTITUTIONAL VALUES ${ }^{1}$
}

\begin{abstract}
Summary
The aim of this paper is to analyse public policy under the Article $\mathrm{V}(2)(\mathrm{b})$ of the New York Convention as an instrument protecting the right to a fair trial. The core part of the paper is based on the analysis of selected case law of national courts applying the New York Convention. Firstly, the concept of public policy under Article the $\mathrm{V}(2)(\mathrm{b})$ and the principles of its interpretation are analysed in general. In this part, the standard of international public policy is explained. The standard of international public policy does not represent an international or supranational standard. It is still the standard based on national law which is applicable to foreign arbitral awards. Secondly, the right to a fair trial within the context of public policy is assessed. This part is mainly based on the selected case law of national courts. Concerning the right to a fair trial, most of the courts use the standard of international public policy. The national courts generally acknowledge that the right to an independent and impartial arbitrator, as well as the right to present one's case (with the exception of the lack of reasoning in the award) form part of (international) public policy within the meaning of the Article $\mathrm{V}(2)(\mathrm{b})$. However, the threshold for finding the violation of (international) public policy is high.
\end{abstract}

Keywords: New York Convention; public policy; international public policy; right to a fair trial; independence and impartiality of arbitrators; right to present one's case.

\section{Introduction}

For the success of international commercial arbitration, the recognition and enforcement ("recognition") of awards is of paramount importance. At present, there is an international policy favouring recognition of awards. This is mainly the result of the rules contained in the (New York) Convention on the Recognition and Enforcement of Foreign Arbitral Awards² ("Convention").

The obligation of national courts to recognise foreign arbitral awards as provided in Article III of the Convention is subject to limited exceptions. Inter alia, the court may refuse recognition if the recognition of an award violates that state's public policy

This paper is created within the project supported by the Grant Agency of the Czech Republic GA15-08182S The Role of Public Interests in International Commercial and Investment Arbitration.

2 Convention on the Recognition and Enforcement of Foreign Arbitral Awards (New York, 1958). Available at http://www.uncitral.org/uncitral/en/uncitral_texts/arbitration/NYConvention.html [last viewed May 22, 2016]. 
(Article $\mathrm{V}(2)(\mathrm{b}))$. The text of the provision refers to the public policy of the state of recognition. Thus, it seems that the states are enabled to apply their national standards of public policy, which can vary from jurisdiction to jurisdiction.

It is generally assumed that public policy of states incorporate their constitutional rights, ${ }^{3}$ including the right to a fair trial. The question arises, whether the right to a fair trial is regarded as a part of public policy within the meaning of the Article $V(2)(b)$ and, if so, to what extent. Each state has its own definition of the right to a fair trial, which can vary for court proceedings and arbitration. The aim of this paper is to analyse public policy under the Article $\mathrm{V}(2)(\mathrm{b})$ of the Convention as an instrument protecting the right to a fair trial. The paper will have the following structure. Firstly, the concept of public policy under the Article $\mathrm{V}(2)(\mathrm{b})$ will be analysed in general. Secondly, the right to a fair trial within the context of public policy will be assessed. This part will be based on the selected case law of national courts applying the Convention. ${ }^{4}$ The main aim of the analysis is to identify what "standard" of the public policy national courts apply, if the right to a fair trial is regarded as a part of public policy and what threshold is required for the violation of public policy under the Article V(2)(b).

\section{Public policy under the Article $\mathrm{V}(2)(\mathrm{b})$ in general}

Article $\mathrm{V}(2)$ contains two grounds for refusal of recognition of foreign arbitral awards. Both of them may be examined by national courts ex officio, i.e. from their own motion. The burden of proof rests, however, on the party against whom an award is invoked. ${ }^{5}$

Public policy is a traditional institute of Private International Law. The biggest problem of this institute is its precise definition. Theory and practice generally agree that public policy reflects the moral, social, economic or legal values so important that they must be protected under all circumstances and without exceptions. The purpose of public policy is to protect the fundamental principles of society. ${ }^{6}$

3 Kronke H., Nacimiento P. Recognition and Enforcement of Foreign Arbitral Awards: A Global Commentary on the New York Convention. The Hague: Kluwer Law International, 2010, p. 366.

4 It is practically impossible to include all the relevant cases on this issue. The paper reflects the case law of the European countries that are either frequent seats of arbitration (e.g. France, Switzerland) or in which foreign arbitral awards are regularly enforced (e.g. Germany). All the cases were taken from Yearbooks Commercial Arbitration. In the footnotes, the shortened version of citation will be used. The full citation can be found in the bibliography.

5 Kronke H., Nacimiento P. Recognition and Enforcement of Foreign Arbitral Awards: A Global Commentary on the New York Convention. The Hague: Kluwer Law International, 2010, p. 348; Kurkela S. M., Turunen A. Due Process in International Commercial Arbitration. $2^{\text {nd }}$ edition. New York: Oxford University Press, 2010, p. 18; Born G. B. International Commercial Arbitration. $2^{\text {nd }}$ edition. Alphen aan den Rijn: Kluwer Law International, 2014, p. 3651.

6 Shaleva V. The Public Policy Exception to the Recognition and Enforcement of Arbitral Awards in the Theory and Jurisprudence of the Central and East European States and Russia. Arbitration International, 2003, Vol. 19, No. 1, pp. 67-68; Born G. B. International Commercial Arbitration. $2^{\text {nd }}$ edition. Alphen aan den Rijn: Kluwer Law International, 2014, p. 3648. 
The Article $\mathrm{V}(2)(\mathrm{b})$ does not provide any definition of public policy. Instead, it refers to the public policy of the country in which the recognition is sought. It is thus up to that state to define what constitutes the public policy in its jurisdiction. ${ }^{7}$ Therefore, it is inevitable that the content of public policy may vary from country to country. ${ }^{8}$ This raises the risk of inconsistent and contradictory decisions, ${ }^{9}$ failing to comply with the objective of the Convention. ${ }^{10}$ Consequently, legislatures, courts and scholars have tried to internationalize national standard of public policy. Several different conceptions have been adopted, however, only the standard of international public policy is widely accepted. ${ }^{11}$ International public policy is essentially national and is understood as a public policy of enforcement state with respect to international matters. ${ }^{12}$ The content of public policy is defined by the law of the enforcement state, but the Convention's objectives place international constraints on it. Consequently, public policy defence has to be construed narrowly and serves as an exceptional instrument. ${ }^{13}$ It should include only the fundamental policies of a state, which are expressed in constitutional, legislative or judicial instruments. ${ }^{14}$ The conception of international public policy was also confirmed by the International Law Association ("ILA") it its Final ILA Report on Public Policy as a Bar to Enforcement of International Arbitral Awards ("ILA Report"). ${ }^{15}$

Balthasar S. (ed.). International Commercial Arbitration. München: C. H. Beck, 2016, p. 143; Wolff R. (ed.) New York Convention: Convention on the Recognition and Enforcement of Foreign Arbitral Awards of 10 June 1958 Commentary. München: C. H. Beck, 2012, p. 407.

8 Wolff R. (ed.). New York Convention: Convention on the Recognition and Enforcement of Foreign Arbitral Awards of 10 June 1958 Commentary. München: C. H. Beck, 2012, p. 407; Born G. B. International Commercial Arbitration. $2^{\text {nd }}$ edition. Alphen aan den Rijn: Kluwer Law International, 2014, p. 3654.

9 Wolff R. (ed.). New York Convention: Convention on the Recognition and Enforcement of Foreign Arbitral Awards of 10 June 1958 Commentary. München: C. H. Beck, 2012, pp. 403 and 405.

10 Born G. B. International Commercial Arbitration. $2^{\text {nd }}$ edition. Alphen aan den Rijn: Kluwer Law International, 2014, p. 3655.

11 Other conceptions are: transnational or truly international public policy where the standard is derived from international sources and the national public policy in conformity with international sources. Both these standards try to replace the national standard with an international or supranational standard. This is, however, irreconcilable with the wording of Article $\mathrm{V}(2)(\mathrm{b})$. For details, see Wolff R. (ed.). New York Convention: Convention on the Recognition and Enforcement of Foreign Arbitral Awards of 10 June 1958 Commentary. München: C. H. Beck, 2012, p. 408; Born G. B. International Commercial Arbitration. $2^{\text {nd }}$ edition. Alphen aan den Rijn: Kluwer Law International, 2014, pp. 3657-3658.

12 Born G. B. International Commercial Arbitration. $2^{\text {nd }}$ edition. Alphen aan den Rijn: Kluwer Law International, 2014, p. 3659.

13 Ibid., p. 3663.

${ }_{14}$ Kronke H., Nacimiento P. Recognition and Enforcement of Foreign Arbitral Awards: A Global Commentary on the New York Convention. The Hague: Kluwer Law International, 2010, p. 366; Balthasar S. (ed.). International Commercial Arbitration. München: C. H. Beck, 2016, p. 144; van den Berg A. J. The New York Arbitration Convention of 1958. Towards a Uniform Judicial Interpretation. The Hague: T. M. C. Asser Institute, 1981, p. 360; Born G. B. International Commercial Arbitration. $2^{\text {nd }}$ edition. Alphen aan den Rijn: Kluwer Law International, 2014, p. 3663.

15 For the whole ILA Report see Mayer P., Sheppard A. Final ILA Report on Public Policy as a Bar to Enforcement of International Arbitral Awards. Arbitration International. 2003, Vol. 19, No. 2, pp. $249-263$. 


\section{Right to a fair trial under the Convention}

Concerning the right to a fair trial, there is an overlap between the Article $\mathrm{V}(2)(\mathrm{b})$ and the Article $\mathrm{V}(1)(\mathrm{b})$. If the right to a fair trial was only covered by the Article (1)(b), a court would not have a possibility to refuse the recognition on its own motion, if it found that there was a violation of the right to a fair trial. ${ }^{16}$ Under the majority opinion, the Article $\mathrm{V}(1)$ (b) does not have such an effect. Violation of the right to a fair trial can be assessed under both Article $\mathrm{V}(1)(\mathrm{b})$ and $\mathrm{V}(2)(\mathrm{b}){ }^{17}$

\subsection{Case law of national courts}

Within the context of public policy, the national courts in the analysed case law assessed the right to an independent and impartial tribunal and the right to present one's case including the right to be heard, the principle of equal treatment and the right to obtain a reasoned decision.

When determining the content of public policy, the courts referred to the fundamental or basic principles or values of a legal order, ${ }^{18}$ state's basic principles of social and economic life, ${ }^{19}$ understanding of justice, ${ }^{20}$ foundations of public and economic life ${ }^{21}$ or fundamental state, moral, social, judicial or economic concepts. ${ }^{22}$ The courts also stated that a public policy defence had a more limited scope in the context of recognition of foreign arbitral awards. ${ }^{23}$ In other words, they distinguished between domestic and international public policy, when assessing the right to a fair trial. ${ }^{24}$ The courts acknowledged that the threshold for the violation international public policy is

${ }^{16}$ van den Berg A. J. The New York Arbitration Convention of 1958. Towards a Uniform Judicial Interpretation. The Hague: T.M.C. Asser Institute, 1981, p. 300.

17 van den Berg A. J. The New York Arbitration Convention of 1958. Towards a Uniform Judicial Interpretation. The Hague: T.M.C. Asser Institute, 1981, p. 300; Lew J. D. M., Mistelis L. A., Kröll S. M. Comparative International Commercial Arbitration. The Hague: Kluwer Law International, 2003, p. 711; Kurkela S. M., Turunen A. Due Process in International Commercial Arbitration. $2^{\text {nd }}$ edition. New York: Oxford University Press, 2010, p. 21; Poudret J. F., Besson S. Comparative Law of International Arbitration. $2^{\text {nd }}$ edition. London: Sweet \& Maxwell, 2007, p. 858. For different opinion see Born G. B. International Commercial Arbitration. $2^{\text {nd }}$ edition. Alphen aan den Rijn: Kluwer Law International, 2014, p. 3688.

18 Decision of Corte di Appello di Venezia, Italy, Case: S.A., Pando Compania Naviera v. S.a.S. Filmo; Decision of Oberlandesgericht Hamm, Germany, Case No. 25 Sch 09/08; Decision of Corte di Appello di Milano, Italy, Case: Impianti SpA vs. B.M.A.A.B. and Sons International Contracting Company WLL; Decision of Oberlandesgericht Stuttgart, Germany, Case No. 5 U 89/98; Decision of Cour de Justice Genève, Switzerland, Case: Léopold Lazarus Ltd. vs. Chrome Ressources S.A.; Decision of Bezirksgericht Zurich, Switzerland, Case: Italian party vs. Swiss company; Decision of Hanseatisches Oberlandesgericht Bremen, Germany of 30 September 1999.

19 Decision of Oberlandesgericht Celle, Germany, Case No. 8 Sch 06/06.

20 Decision of Camera di Esecuzione e Fallimenti Canton Tessin, Switzerland, Case: AG vs. C.C. SA.

21 Decision of Bundesgerichtshof, Germany of 14 April 1988.

22 Decision of Areios Pagos, Greece, Case No. 1006.

23 Decision of Camera di Esecuzione e Fallimenti Canton Tessin, Switzerland, Case: AG vs. C.C. SA; Decision of Cour de Justice Genève, Switzerland, Case: Léopold Lazarus Ltd. vs. Chrome Ressources S.A.; Decision of Oberlandesgericht Celle, Germany, Case No. 8 Sch 15/05.

${ }^{24}$ Decision of Corte di Appello di Venezia, Italy, Case: S.A. Pando Compania Naviera vs. S.a.S. Filmo; Decision of Hanseatisches Oberlandesgericht Bremen, Germany of 30 September 1999. 
high. For example, the courts required a grave defect in the arbitration proceedings that affected the state's basic principles, ${ }^{25}$ manifest contrast with justice, ${ }^{26}$ evident irreconcilability with basic principles of law $^{27}$ or breach in an unacceptable manner. ${ }^{28}$

Few courts expressly referred to their constitutional provisions providing for the right to a fair trial. They concluded that public policy demanded compliance with the fundamental rules of procedure deriving from the constitution such as the right to a fair trial including the right to be heard and arbitrator's independence and impartiality. ${ }^{29}$ At the same time, it followed from this case law that the specific characteristics of arbitration and specifically those of international arbitration must have been taken into account. ${ }^{30}$ Several courts only referred to their public policy in general without any closer definition or they generally referred to their basic principles. Nevertheless, even in these cases, the high threshold for the violation of public policy was visible. ${ }^{31}$ In any case, the national courts approved that not all mandatory rules of domestic procedure were covered by public policy. ${ }^{32}$

It follows from the analysed case law that the courts referred to the public policy of their own country, which is in line with the provision of Article $V(2)(b)$. Not all the courts expressly used or mentioned the concept of international public policy. However, they, at least implicitly, employed the limited scope of public policy towards foreign arbitral awards.

25 Decision of Oberlandesgericht Celle, Germany, Case No. 8 Sch 06/06; Decision of Hanseatisches Oberlandesgericht Bremen, Germany of 30 September 1999; Decision of Bundesgerichtshof, Germany of 14 April 1988.

26 Decision of Camera di Esecuzione e Fallimenti Canton Tessin, Switzerland, AG vs. C.C. SA.

27 Decision of Oberlandesgericht Hamm, Germany, Case No. 25 Sch 09/08.

28 Decision of Bezirksbericht Zurich, Switzerland, Case: Italian party vs. Swiss company.

29 See, e.g. Decision of Tribunal Fédéral, Switzerland, Case: X SA vs. Y.; Decision of Superior Court of Justice of Catalonia, Spain, Case No. 46/2013, Sierra-Affinity, LLC vs. Wide Pictures, S.L.; Decision of Tribunal Supremo, Spain, Case: Precious Stone Shipping Limited vs. Querqus Alimentaria, SL.; Decision of Tribunal Supremo, Spain, Case: Gaststättenbetriebs GmbH vs. Almendrera Industrial Catalana, SA (ALICSA); Decision of Oberlandesgericht München, Germany of 28 November 2005; Decision of Oberlandesgericht München, Germany, Case No. 34 Sch 10/11; Decision of Corte di Appello di Genova, Italy, Case: Exfinos Shipping Co. Ltd. Vs. Rawi Shipping Lines Ltd.

30 See e.g. Decision of Tribunal Fédéral, Switzerland, Case: X SA vs. Y.; Decision of Tribunal Supremo, Spain, Case: Precious Stone Shipping Limited vs. Querqus Alimentaria, SL.; Decision of Oberlandesgericht München, Germany, Case No. 34 Sch 10/11; Decision of Corte di Appello di Genova, Italy, Case: Exfinos Shipping Co. Ltd. vs. Rawi Shipping Lines Ltd.

31 Decision of Cour de Cassation, France, Case: Excelsior Film TV, srl. vs. UGC-PH; Decision of Gerechtshof Amsterdam, Netherlands, Case: G.W.L Kersten \& Co. B.V. vs. Société Commerciale Raoul-Duval et Cie; Decision of Kammgericht Berlin, Germany, Case No. 20 Sch 02/08; Decision of Rechtbank Rotterdam, Netherlands, Case: Catz International B.V. vs. Gilan Trading KFT; Decision of Oberlandesgericht Thüringen, Germany, Case No. 4 Sch 01/03; Decision of Oberlandesgericht Düsseldorf, Germany, Case No. I-4 Sch 10/09; Decision of Oberlandesgericht Karlsruhe, Germany of 14 September 2007, Case No. 9 Sch 02/07; Decision of Rechtbank Arnhem, Netherlands of 27 September 2012, Case: Bayeti Farm Enterprises Limited vs. Cooperatie TGS U.A. and Hatch Tech B.V.

32 Decision of Oberlandesgericht Celle, Germany, Case No. 8 Sch 06/06; Decision of Oberlandesgericht Stuttgart, Germany, Case No. 5 U 89/98; Decision of Oberlandesgerich München, Germany, Case No. 34 Sch 7/12; Poudret, J.F., Besson, S. Comparative Law of International Arbitration. $2^{\text {nd }}$ edition. London: Sweet \& Maxwell, 2007, p. 857. 


\subsubsection{Independence and impartiality of arbitrators}

The national courts have generally acknowledged that the right to an independent and impartial arbitrator forms part of public policy within the meaning of the Article V(2)(b). However, the threshold for finding the violation of (international) public policy is high. The national courts in most cases required that the alleged bias had to be proven. To meet the burden of proof, the defendant must prove facts that indicate bias. ${ }^{33}$ The courts also mostly required that the partiality had an actual impact on an arbitral award. ${ }^{34}$ Moreover, courts often required that the objection of bias must have been raised first in the country of origin of the award. Only if it was impossible to raise this objection, or the objection was raised unsuccessfully, could the enforcement courts examine, whether an award violates public policy. ${ }^{35}$

Various facts have arisen in the process of arguing that the arbitrator or the arbitral tribunal was not impartial, e.g. a claimant's counsel and an arbitrator practised before the same court, ${ }^{36}$ a counsel accompanied an arbitrator's daughter to a social event, ${ }^{37}$ an arbitrator was a member of an association, of which two companies related to the party were also a member, ${ }^{38}$ one of the arbitrators spoke at a conference either financed or co-organised by the claimant's counsel, ${ }^{39}$ nationality of all three arbitrators was the same as the nationality of one of the parties. ${ }^{40}$ None of these situations led to a violation of international public policy. On the other hand, the situation, in which arbitrator appointed by the claimant rendered an award as the sole arbitrator and at the same time had acted on behalf of the claimant previous to the arbitration, violated the public policy. ${ }^{41}$ The same was true in the situation, in which the same arbitrator was appointed by the same party in parallel arbitrations and the arbitrator

33 Kronke H., Nacimiento P. Recognition and Enforcement of Foreign Arbitral Awards: A Global Commentary on the New York Convention. The Hague: Kluwer Law International, 2010, p. 371; e. g. Decision of Superior Court of Justice of Catalonia, Spain of 25 March 2013, Case No. 46/2013, Sierra-Affinity, LLC vs. Wide Pictures, S.L.; Decision of Tribunal Fédéral, Switzerland of 28 July 2010, Case: X SA vs. Y.; Decision of Oberlandesgericht Karlsruhe, Germany, Case No. 9 Sch 02/07; Decision of Camera di Esecuzione e Fallimenti Canton Tessin, Switzerland, Case: AG vs. C.C. SA.; Decision of Corte di Appello di Milano, Italy, Case: Impianti SpA vs. B.M.A.A.B. and Sons International Contracting Company WLL.

34 Wolff R. (ed.). New York Convention: Convention on the Recognition and Enforcement of Foreign Arbitral Awards of 10 June 1958 Commentary. München: C. H. Beck, 2012, p. 421; Decision of Oberlandesgericht Hamm, Germany, Case No. 25 Sch 09/08; Decision of Oberlandesgericht Celle, Germany, Case No. 8 Sch 06/06; Decision of Superior Court of Justice of Catalonia, Spain, Case No. 46/2013, Sierra-Affinity, LLC vs. Wide Pictures, S.L.

35 Wolff R. (ed.). New York Convention: Convention on the Recognition and Enforcement of Foreign Arbitral Awards of 10 June 1958 Commentary. München: C. H. Beck, 2012, p. 420; Decision of Bundesgerichtshof, Germany of 1 February 2001; Decision of Camera di Esecuzione e Fallimenti Canton Tessin, Switzerland, Case: AG vs. C.C. SA.

36 Decision of Tribunal Fédéral, Switzerland, Case: X SA vs. Y.

37 Ibid.

38 Decision of Oberlandesgericht Celle, Germany, Case No. 8 Sch 06/06.

39 Decision of Oberlandesgericht Hamm, Germany, Case No. 25 Sch 09/08.

40 Decision of Oberlandesgerich Karlsruhe, Germany, Case No. 9 Sch 02/07.

${ }_{41}$ Decision of Oberlandesgericht Stuttgart, Germany, Case No. 5 U 89/98. 
conveyed erroneous information to the second panel, which influenced the tribunal's decision on jurisdiction. ${ }^{42}$

\subsubsection{The right to present one's case}

Similarly, as to the right to an impartial arbitrator, the national courts have generally acknowledged that the right to present one's case forms a part of public policy within the meaning of the Article $\mathrm{V}(2)(\mathrm{b}) .{ }^{43}$ The key element of the right to present one's case is the right to be heard. The violation of this right would generally render the award unenforceable for the violation of public policy. ${ }^{44}$ However, it is again apparent that the threshold for the violation of public policy is high. The courts require the defendant to prove that his right to be heard has been violated. ${ }^{45}$ Moreover, the violation has to be material and real, ${ }^{46}$ and appears clearly from the decision. ${ }^{47}$ The actual result of an award must be in conflict with public policy. ${ }^{48}$

The right to be heard comprises the right of the parties to present their arguments and their right to submit supporting evidence. However, the courts found that the public policy was not violated, if the parties had been given the opportunity to present their arguments and submit evidence. ${ }^{49}$ The sole fact that the tribunal refused a request to carry out an oral hearing does not violate the right to be heard, if the defendant had the opportunity to fully present its arguments in writing. ${ }^{50}$ The fact that a party did not participate in the arbitral proceeding or did not attend the hearing itself, does not lead to the violation of the right to be heard. If the party had an opportunity to participate, its right to be heard was not violated. ${ }^{51}$

The right to be heard also comprises the arbitral tribunal's obligation to consider parties' submission. This does not, however, mean that the tribunal has to deal with each single argument. It must be possible to assume that the tribunal was aware of

42 Decision of Cour de Cassation, France, Case: Excelsior Film TV, srl. vs. UGC-PH.

43 Wolff R. (ed.). New York Convention: Convention on the Recognition and Enforcement of Foreign Arbitral Awards of 10 June 1958 Commentary. München: C. H. Beck, 2012, p. 422.

44 Kronke H., Nacimiento P. Recognition and Enforcement of Foreign Arbitral Awards: A Global Commentary on the New York Convention. The Hague: Kluwer Law International, 2010, p. 387.

45 Decision of Bezirksgericht Zurich, Switzerland, Case: Italian party vs. Swiss company; Decision of Oberlandesgericht Celle, Germany, Case No. 8 Sch 15/05.

46 Decision of Tribunal Supremo, Spain, Case: Gaststättenbetriebs GmbH vs. Almendrera Industrial Catalana, SA (ALICSA).

47 Decision of Oberlandesgericht München, Germanyy Case No. 34 Sch 10/11.

48 Decision of Oberlandesgericht München, Germany of 28 November 2005.

49 Decision of Tribunal Supremo, Spain, Case: Precious Stone Shipping Limited vs. Querqus Alimentaria, SL; Decision of Tribunal Supremo, Spain, Case: Centrotex, S.A. vs. Agencia Gestora de Negocios, S.A.; Decision of Oberlandesgericht Celle, Germany, Case No. 8 Sch 15/05; Decision of Areios Pagos, Greece, Case No. 1006; Decision of the Kammgericht Berlin, Germany, Case No. 20 Sch 02/08; Decision of Oberlandesgericht Frankfurt am Main, Germany, Case No. 26 Sch 03/09; Decision of Rechtbank Rotterdam, Netherlands, Case: Catz International B.V. vs. Gilan Trading KFT.

50 Decision of Oberlandesgericht Frankfurt am Main, Germany, Case No. 26 Sch O3/09.

51 Decision of Oberlandesgerich München, Germany, Case No. 34 Sch 7/12; Decision of Rechtbank Amsterdam, Netherlands, Case: V/O Tractorexport vs. Dimpex Trading B.V.; Decision of Landgericht Bremen, Germany 8 June 1967; Decision of Landgericht Zweibrücken, Germany of 11 January 1978. 
parties' agreement. ${ }^{52}$ There would be a violation of public policy, if it appears clearly from the decision that this was not the case in respect of a point that could not be disregarded and was of fundamental importance to the argument of the parties. ${ }^{53}$ The arbitral tribunal must examine the evidence offered. However, no violation of public policy can be inferred from a failure to provide reasons for refusing a request for evidence, where the arbitral tribunal does not completely pass the request for evidence over in silence, but deals with it at least briefly. ${ }^{54}$

The tribunal also has the duty to communicate party's statements, documents and other information to the other party, as well as expert reports to the parties. If the tribunal does not communicate to the defendant a claimant's document containing certain facts, as well as a legal argument, the right to be heard is violated. ${ }^{55}$

Lack of reasons in an arbitral award was raised on the public policy grounds in quite many cases. Although the particularities of the cases differ, the courts have concluded that the lack of reasoning in foreign arbitral award itself does not violate the (international) public policy under Article $\mathrm{V}(2)(\mathrm{b})$. The courts have come to this conclusion even in case where the reasoning would be required for domestic awards. ${ }^{56}$

\subsubsection{Article 6(1) of the ECHR}

All the states that are reflected in this paper, are Contracting States to the Convention for the Protection of Human Rights and Fundamental Freedoms ${ }^{57}$ ("ECHR"). Article 6(1) of the ECHR establishes the basic procedural rights and ensures a fair trial. ${ }^{58}$ The question arises, whether the Contracting States have to apply Article 6(1) on the public policy grounds of Article $\mathrm{V}(2)(\mathrm{b})$ of the Convention. This question is a part of a larger discussion about the applicability of Article 6(1) of the ECHR to international commercial arbitration. In these days, it is not possible to leave the relationship between Article 6(1) and arbitration untouched. Both theory and case law of the European Court of Human Rights suggest that it is necessary

52 Decision of Oberlandesgericht München, Germany, Case No. 34 Sch 10/11; Decision of Oberlandesgericht Frankfurt am Main, Germany, Case No. 26 Sch O3/09.

53 Decision of Oberlandesgericht München, Germany, Case No. 34 Sch 10/11.

54 Ibid.

55 Decision of Gerechtshof Amsterdam, Netherlands, Case: G.W.L Kersten \& Co. B.V. vs. Société Commerciale Raoul-Duval et Cie.

56 Decision of Corte di Appello di Firenze, Italy, Case: Tradax Export vs. S.p.a. Carapelli; Decision of Corte di Appello di Genova, Italy, Case: Exfinos Shipping Co. Ltd. vs. Rawi Shipping Lines Ltd; Decision of Areios Pagos, Greece, Case: Greek company vs. Foreign company; Decision of Court of Appeal of Athens, Greece of 1984; Decision of Hanseatisches Oberlandesgericht Bremen, Germany of 30 September 1999; Decision of Oberlandesgericht Thüringen, Germany, Case No. 4 Sch 01/03; Decision of Oberlandesgericht Düsseldorf, Germany, Case No. Sch 10/09; Decision of Rechtbank Arnhem, Netherlands, Case: Bayeti Farm Enterprises Limited vs. Cooperatie TGS U.A. and Hatch Tech B.V.

57 Convention for the Protection of Human Rights and Fundamental Freedoms (Rome, 1950). Available at http://www.echr.coe.int/Documents/Convention_ENG.pdf [last viewed November 5, 2016].

58 Besson S. Arbitration and Human Rights. ASA Bulletin. 2006, Vol. 24, No. 3, p. 396. 
to analyse this relationship. In the past, three main arguments have been raised against the application of Article 6(1) of the ECHR to arbitration. All of them seem to be overcome. ${ }^{59}$

From Article 1 and 6(1) of the ECHR follows that the Contracting States shall secure to everyone within their jurisdiction a fair and public hearing within a reasonable time by an independent and impartial tribunal established by law. It is the obligation of result. ${ }^{60}$ This obligation cannot be exhausted by creating judicial system and by ensuring that court proceedings correspond to Article 6(1). The rights established by Article 6(1) must be ensured also to those who choose arbitration. Consequently, the Contracting States shall enact legal regulation that secure the respect for rights guaranteed by Article 6(1) in arbitration and they should refuse to recognise or enforce an arbitral award that contradicts Article 6(1). ${ }^{61}$ It does not, however, mean that every breach would result in the refusal. It can be deduced from the case law of the European Court of Human Rights that the recognition of an arbitral award does not have to be refused because the parties have not enjoyed all the rights guaranteed by Article 6(1). ${ }^{62}$ The courts should have taken into account the nature of arbitration proceeding and the possible waiver of rights enshrined in Article 6(1) ${ }^{63}$

In conclusion, the Contracting States to the ECHR shall, in principle, apply Article 6(1) of the ECHR, when applying Article V(2)(b) of the Convention. If the court recognised an award that clearly contradicted Article 6(1), the State would be responsible under the ECHR. However, the restrictive approach employed by

59 See Besson S. Arbitration and Human Rights. ASA Bulletin. 2006, Vol. 24, No. 3, pp. 400-402. For overview of these arguments, see also Drličková K. Aplikace článku 6 odst. 1 Úmluvy o ochraně lidských práv a základních svobod v rozhodčím řízení. In: Čičkánová D., Hapčová I., Mičátek V. (eds.). Bratislavské právnické fórum 2015. Bratislava: Univerzita Komenského v Bratislave, Právnická fakulta, 2015, pp. 593-602.

${ }^{60}$ Jaksic A. Arbitration and Human Rights. Frankfurt am Main: Peter Lang GmbH, 2002, p. 106.

${ }_{61}$ Besson S. Arbitration and Human Rights. ASA Bulletin. 2006, Vol. 24, No. 3, p. 404.

62 Decision of the European Commission of Human Rights of 27 November 1996, Case: Nordström-Janzon and Nordström-Lehtinen v. the Netherlands, Application No. 20101/95. In: HUDOC. Available http://hudoc.echr.coe.int/eng\#\{\%22appno\%22:[\%2228101/95\%22],\%22i temid\%22:[\%22001-3400\%22]\} [viewed 2016. 05 November]; Judgment of the European Court of Human Rights of 23 February 1999, Case: Suovaniemi and others v. Finland, Application No. 31737/96. In: HUDOC. Available http://hudoc.echr.coe.int/eng\#\{\%22fulltext\%22:[\%223173 7/96\%22],\%22itemid\%22:[\%22001-4942\%22]\} [viewed 2016. 05 November].

${ }_{63}$ For detailed analysis of the relationship between Article 6(1) and arbitration, see e.g. Jaksic A. Arbitration and Human Rights. Frankfurt am Main: Peter Lang GmbH, 2002; Besson S. Arbitration and Human Rights. ASA Bulletin. 2006, Vol. 24, No. 3, pp. 395-416; Jaksic A. Procedural Guarantees of Human Rights in Arbitration Proceedings. Journal of International Arbitration. 2007, Vol. 24, No. 2, pp. 159-172; Bělohlávek A. J. Arbitration from Perspective of Right to Legal Protection and Right to Court Proceedings (the Right to Have One's Case Dealt with by a Court): Significance of Autonomy and Scope of Right to Fair Trial. In: Bělohlávek A. J., Rozehnalová N. (eds.). Czech and Central European Yearbook of Arbitration. The Relationship between Constitutional Values, Human Rights and Arbitration, 2011. New York: JurisNet, LLC, 2011, pp. 47-70; Drličková K. Aplikace článku 6 odst. 1 Úmluvy o ochraně lidských práv a základních svobod v rozhodčím řízení. In: Čičkánová D., Hapčová I., Mičátek V. (eds.). Bratislavské právnické fórum 2015. Bratislava: Univerzita Komenského v Bratislave, Právnická fakulta, 2015, pp. 593-602. 
national courts within the context of Article $\mathrm{V}(2)(\mathrm{b})$ of the Convention seems to be compatible with Article 6(1) of the ECHR. ${ }^{64}$

\section{Conclusion}

Public policy as grounds for refusal of recognition can be examined by national courts ex officio. The burden of proof rests, however, on the party against whom an award is invoked. The Article $\mathrm{V}(2)(\mathrm{b})$ does not provide any autonomous definition of public policy. Instead, it refers to the public policy of the country, in which the recognition is sought. It is, thus, up to that state to define, what constitutes public policy in its jurisdiction. It is clear from the wording of the Article $\mathrm{V}(2)(\mathrm{b})$ that only a national standard of public policy is compatible with the text of this provision. However, at present, the standard of international public policy has become widespread. The standard of international public policy does not represent an international or supranational standard. It is still the standard based on national law, which is applicable to foreign arbitral awards. The national courts are forced to determine the contents of their international public policy, restrictively.

Concerning the right to a fair trial, most of the courts in the analysed cases used the standard of international public policy. The national courts generally acknowledged that the right to an independent and impartial arbitrator, as well as the right to present one's case (with the exception of the lack of reasoning in the award) formed a part of (international) public policy within the meaning of the Article V(2)(b). However, the threshold for finding the breach of (international) public policy was high. Only the most serious and flagrant violations of this right amounted to the violation of international public policy within the meaning of Article V(2)(b).

\section{BIBLIOGRAPHY}

\section{Literature}

1. Balthasar S. (ed.). International Commercial Arbitration. München: C. H. Beck, 2016, 701 p.

2. Bělohlávek A. J. Arbitration from Perspective of Right to Legal Protection and Right to Court Proceedings (the Right to Have One's Case Dealt with by a Court): Significance of Autonomy and Scope of Right to Fair Trial. In: Bělohlávek A. J., Rozehnalová N. (eds.). Czech and Central European Yearbook of Arbitration. The Relationship between Constitutional Values, Human Rights and Arbitration 2011. New York: JurisNet, LLC, 2011, pp. 47-70.

3. Besson S. Arbitration and Human Rights. ASA Bulletin. 2006, Vol. 24, No. 3, pp. 395-416.

${ }^{64}$ The author of this paper is fully aware that most of the states reflected in this paper are Member States of European Union. Therefore, a reference to so-called European public policy should be made. However, according to the opinion of the author, the discussions on the European public policy are mostly relevant for the substantive public policy, thus, this issue is not analysed in detail in this paper. 
4. Blackaby N., Partasides C. Redfern and Hunter on International Arbitration. $6^{\text {th }}$ edition. New York: Oxford University Press, 2015, 859 p.

5. Born, G. B. International Commercial Arbitration. $2^{\text {nd }}$ edition. Alphen aan den Rijn: Kluwer Law International, 2014, $4260 \mathrm{p}$.

6. Drličková K. Aplikace článku 6 odst. 1 Úmluvy o ochraně lidských práv a základních svobod v rozhodčím řízení. In: Čičkánová D., Hapčová I., Mičátek V. (eds.). Bratislavské právnické fórum 2015. Bratislava: Univerzita Komenského v Bratislave, Právnická fakulta, 2015. pp. 593-602.

7. Jaksic A. Arbitration and Human Rights. Frankfurt am Main: Peter Lang GmbH, 2002, 370 p.

8. Jaksic A. Procedural Guarantees of Human Rights in Arbitration Proceedings. Journal of International Arbitration. 2007, Vol. 24, No. 2, pp. 159-172.

9. Kronke H., Nacimiento P. Recognition and Enforcement of Foreign Arbitral Awards: A Global Commentary on the New York Convention. The Hague: Kluwer Law International, 2010, $617 \mathrm{p}$.

10. Kurkela S. M., Turunen A. Due Process in International Commercial Arbitration. $2^{\text {nd }}$ edition. New York: Oxford University Press, 2010, 555 p.

11. Lew J. D. M., Mistelis L. A., Kröll S. M. Comparative International Commercial Arbitration. The Hague: Kluwer Law International, 2003, 953 p.

12. Mayer P., Sheppard A. Final ILA Report on Public Policy as a Bar to Enforcement of International Arbitral Awards. Arbitration International. 2003, Vol. 19, No. 2, pp. 249-263.

13. Poudret J. F., Besson S. Comparative Law of International Arbitration. $2^{\text {nd }}$ edition. London: Sweet \& Maxwell, 2007, 952 p.

14. Shaleva V. The Public Policy Exception to the Recognition and Enforcement of Arbitral Awards in the Theory and Jurisprudence of the Central and East European States and Russia. Arbitration International, 2003, Vol. 19, No. 1, pp. 67-93.

15. van den Berg A. J. The New York Arbitration Convention of 1958. Towards a Uniform Judicial Interpretation. The Hague: T.M.C. Asser Institute, 1981, 466 p.

16. Wolff R. (ed.). New York Convention: Convention on the Recognition and Enforcement of Foreign Arbitral Awards of 10 June 1958 Commentary. München: C. H. Beck, 2012, 612 p.

\section{Legislative acts}

1. Convention for the Protection of Human Rights and Fundamental Freedoms (Rome, 1950). Available at http://www.echr.coe.int/Documents/Convention_ENG.pdf [last viewed November 5, 2016].

2. Convention on the Recognition and Enforcement of Foreign Arbitral Awards (New York, 1958). Available at http://www.uncitral.org/uncitral/en/uncitral_texts/arbitration/ NYConvention.html [last viewed May 22, 2016].

\section{Legal practice}

\section{European Court of Human Rights}

1. Decision of the European Commission of Human Rights of 27 November 1996, Case: Nordström-Janzon and Nordström-Lehtinen v. the Netherlands, Application No. 20101/95. In: HUDOC. Available athttp://hudoc.echr.coe.int/eng\#\{\%22appno\%22:[\%2228101/95\% 22],\%22itemid\%22:[\%22001-3400\%22]\} [last viewed November 5, 2016]. 
2. Judgment of the European Court of Human Rights of 23 February 1999, Case: Suovaniemi and others v. Finnland, Application No. 31737/96. In: HUDOC. Available ar http://hudoc.echr. coe.int/eng\#\{\%22fulltext\%22:[\%2231737/96\%22],\%22itemid\%22:[\%22001-4942\%22]\} [last viewed November 5, 2016].

\section{France}

3. Decision of Cour de Cassation, France of 24 March 1998, Case: Excelsior Film TV, srl. vs. UGC-PH. In: van den Berg, A.J. (ed.). Yearbook Commercial Arbitration. Vol. XXIV. The Hague: Kluwer Law International, 1999, pp. 643-644.

\section{Germany}

4. Decision of Landgericht Bremen, Germany 8 June 1967. In: Sanders P. (ed.). Yearbook Commercial Arbitration. Vol. II. The Hague: Kluwer Law International, 1977, p. 234.

5. Decision ofLandgerichtZweibrücken, Germany of 11January 1978.In:Sanders P.(ed.).Yearbook Commercial Arbitration. Vol. IV. The Hague: Kluwer Law International, 1979, pp. 262-263.

6. Decision of Bundesgerichtshof, Germany of 14 April 1988. In: van den Berg A.J. (ed.). Yearbook Commercial Arbitration. Vol. XV. The Hague: Kluwer Law International, 1990, pp. 450-454.

7. Decision of Hanseatisches Oberlandesgericht Bremen, Germany of 30 September 1999. In: van den Berg A. J. (ed.). Yearbook Commercial Arbitration. Vol. XXXI. The Hague: Kluwer Law International, 2006, pp. 640-651.

8. Decision of Oberlandesgericht Stuttgart, Germany of 18 October 1999, Case No. 5 U 89/98. In: van den Berg A.J. (ed.). Yearbook Commercial Arbitration. Vol. XXIX. The Hague: Kluwer Law International, 2004, pp. 700-714.

9. Decision of Bundesgerichtshof, Germany of 1 February 2001. In: van den Berg A. J. (ed.). Yearbook Commercial Arbitration. Vol. XXIX. The Hague: Kluwer Law International, 2004, pp. $708-714$.

10. Decision of Oberlandesgericht Thüringen, Germany of 10 March 2004, Case No. 4 Sch 01/03. In: van den Berg A. J. (ed.). Yearbook Commercial Arbitration. Vol. XXYIII. The Hague: Kluwer Law International, 2008, pp. 495-499.

11. Decision of Oberlandesgericht München, Germany of 28 November 2005. YCA XXXI, 2006, pp. $722-728$

12. Decision of Oberlandesgericht Celle, Germany of 14 December 2006, Case No. 8 Sch 15/05. In: van den Berg A. J. (ed.). Yearbook Commercial Arbitration. Vol. XXII. The Hague: Kluwer Law International, 2007, pp. 372-382.

13. Decision of Oberlandesgericht Celle, Germany of 31 May 2007, No. 8 Sch 06/06. In: van den Berg A. J. (ed.). Yearbook Commercial Arbitration. Vol. XXXIII. The Hague: Kluwer Law International, 2008, pp. 524-533.

14. Decision of Oberlandesgerich Karlsruhe, Germany of 14 September 2007, Case No. 9 Sch 02/07. In: van den Berg A. J. (ed.). Yearbook Commercial Arbitration. Vol. XXXIII. The Hague: Kluwer Law International, 2008, pp. 541-548.

15. Decision of Kammgericht Berlin, Germany of 17 April 2008, Case No. 20 Sch 02/08. In van den Berg, A. J. (ed.). Yearbook Commercial Arbitration. Vol. XXXIV. The Hague: Kluwer Law International, 2009, pp. 510-515. 
16. Decision of Oberlandesgericht Hamm, Germany of 28 November 2008, Case No. 25 Sch 09/08. In: van den Berg A. J. (ed.). Yearbook Commercial Arbitration. Vol. XXXIV. The Hague: Kluwer Law International, 2009, pp. 536-544.

17. Decision of Oberlandesgericht Frankfurt am Main, Germany of 12 October 2009, Case No. 26 Sch O3/09. In: van den Berg A. J. (ed.). Yearbook Commercial Arbitration. Vol. XXXV. The Hague: Kluwer Law International, 2010, pp. 377-380.

18. Decision of Oberlandesgerich Düsseldorf, Germany of 15 December 2009, Case No. I-4 Sch 10/09. In: van den Berg A. J. (ed.). Yearbook Commercial Arbitration. Vol. XXXV. The Hague: Kluwer Law International, 2010, pp. 386-388.

19. Decision of Oberlandesgericht München, Germany of 14 November 2011, Case No. 34 Sch 10/11. In: van den Berg A. J. (ed.). Yearbook Commercial Arbitration. Vol. XXXVII. The Hague: Kluwer Law International, 2012, pp. 231-233.

20. Decision of Oberlandesgerich München, Germany of 21 June 2012, No. 34 Sch 7/12. In: van den Berg A. J. (ed.). Yearbook Commercial Arbitration. Vol. XXXIX. The Hague: Kluwer Law International, 2014, pp. 392-393.

\section{Greece}

21. Decision of Court of Appeal of Athens, Greece of 1984. In: van den Berg A. J. (ed.). Yearbook Commercial Arbitration. Vol. XIV. The Hague: Kluwer Law International, 1989, p. 637.

22. Decision of Areios Pagos, Greece of 1986, Case: Greek company vs. Foreign company. In: van den Berg A. J. (ed.). Yearbook Commercial Arbitration. Vol. XIV. The Hague: Kluwer Law International, 1989, p. 640.

23. Decision of Areios Pagos, Greece of 2007, No. 1006. In: van den Berg A. J. (ed.). Yearbook Commercial Arbitration. Vol. XXXIII. The Hague: Kluwer Law International, 2008, pp. 565-566.

\section{Italy}

24. Decision of Corte di Appelo di Venezia, Italy of 21 May 1976, Case: S.A., Pando Compania Naviera v. S.a.S. Filmo, In: Sanders P. (ed.). Yearbook Commercial Arbitration. Vol. III. The Hague: Kluwer Law International, 1978, p. 277.

25. Decision of Corte di Appello di Firenze, Italy of 22 October 1976, Case: Tradax Export vs. S.p.a. Carapelli, In: Sanders P. (ed.). Yearbook Commercial Arbitration. Vol. III. The Hague: Kluwer Law International, 1978, pp. 279-280.

26. Decision of Corte di Appello di Genova, Italy of 2 May 1980, Case: Exfinos Shipping Co. Ltd. vs. Rawi Shipping Lines Ltd. In: Sanders P. (ed.). Yearbook Commercial Arbitration. Vol. VIII. The Hague: Kluwer Law International, 1983, pp. 381-382.

27. Decision of Corte di Appelo di Milano, Italy of 29 April 2009, Case: Impianti SpA vs. B.M.A.A.B. and Sons International Contracting Company WLL. In: van den Berg A. J. (ed.). Yearbook Commercial Arbitration. Vol. XXXV. The Hague: Kluwer Law International, Vol. 2010, pp. 415-417.

\section{Netherlands}

28. Decision of Rechtbank Amsterdam, Netherlands of 24 April 1991, Case: V/O Tractorexport vs. Dimpex Trading B.V. In: van den Berg A. J. (ed.). Yearbook Commercial Arbitration. Vol. XVII. The Hague: Kluwer Law International, 1992, pp. 572-575. 
29. Decision of Gerechtshof Amsterdam, Netherlands of 16 July 1992, Case: G.W.L Kersten \& Co. B.V. vs. Société Commerciale Raoul-Duval et Cie. In: van den Berg A. J. (ed.). Yearbook Commercial Arbitration. Vol. XIX. The Hague: Kluwer Law International, 1994, pp. 708-709.

30. Decision of Rechtbank Rotterdam, Netherlands of 20 December 2011, Case: Catz International B.V. vs. Gilan Trading KFT. In: van den Berg A. J. (ed.). Yearbook Commercial Arbitration. Vol. XXXVII. The Hague: Kluwer Law International, 2011, pp. 217-273.

31. Decision of Rechtbank Arnhem, Netherlands of 27 September 2012, Case: Bayeti Farm Enterprises Limited vs. Cooperatie TGS U.A. and Hatch Tech B.V. In: van den Berg A. J. (ed.). Yearbook Commercial Arbitration. Vol. XXXVIII. The Hague: Kluwer Law International, 2013, pp. 431-433.

\section{Spain}

32. Decision of Tribunal Supremo, Spain of 28 November 2000, Case: Precious Stone Shipping Limited vs. Querqus Alimentaria, SL. In: van den Berg A. J. (ed.). Yearbook Commercial Arbitration. Vol. XXXII. The Hague: Kluwer Law International, 2007, pp. 540-549.

33. Decision of Tribunal Supremo, Spain of 13 November 2001, Case: Centrotex, S.A. vs. Agencia Gestora de Negocios, S.A. In: van den Berg A. J. (ed.). Yearbook Commercial Arbitration. Vol. XXXI. The Hague: Kluwer Law International, 2006, pp. 834-845.

34. Decision of Tribunal Supremo, Spain of 27 January 2004, Case: Gaststättenbetriebs GmbH vs. Almendrera Industrial Catalana, SA (ALICSA). In: van den Berg A. J. (ed.). Yearbook Commercial Arbitration. Vol. XXXII. The Hague: Kluwer Law International, 2007, pp. 597-602.

35. Decision of Superior Court of Justice of Catalonia, Spain of 25 March 2013, Case No. 46/2013, Sierra-Affinity, LLC vs. Wide Pictures, S.L. In: van den Berg A. J. (ed.). Yearbook Commercial Arbitration. Vol. XXXVIII. The Hague: Kluwer Law International, 2013, pp. 465-467.

\section{Switzerland}

36. Obergericht Basel, Switzerland of 3 June 1971, Case: Dutch seller v. Swiss buyer, In: Sanders P. (ed.). Yearbook Commercial Arbitration. Vol. IV. The Hague: Kluwer Law International, 1979, pp. 309-310.

37. Decision of Cour de Justice Genève, Switzerland of 17 September 1976, Case: Léopold Lazarus Ltd. vs. Chrome Ressources S.A. In: Sanders P. (ed.). Yearbook Commercial Arbitration. Vol. IV. The Hague: Kluwer Law International, 1979, pp. 311-313.

38. Decision of Camera di Esecuzione e Fallimenti Canton Tessin, Switzerland of 19 June 1990, Case: AG vs. C.C. SA. In: van den Berg A. J. (ed.). Yearbook Commercial Arbitration. Vol. XX. The Hague: Kluwer Law International, 1995, pp. 762-765.

39. Decision of Bezirksgericht Zurich, Switzerland of 14 February 2003, Case: Italian party vs. Swiss company. In: van den Berg A. J. (ed.). Yearbook Commercial Arbitration. Vol. XXIX. The Hague: Kluwer Law International, 2004, pp. 819-833.

40. Decision of Tribunal Fédéral, Switzerland of 28 July 2010, Case: X SA vs. Y. In: van den Berg A. J. (ed.). Yearbook Commercial Arbitration. Vol. XXXVI. The Hague: Kluwer Law International, 2011, pp. 337-339. 
Inga Kacevska, Dr. iur

University of Latvia, MCIArb, Latvia

\title{
SCRUTINY OF THE ARBITRATION LAW'S RULES BY THE CONSTITUTIONAL COURT OF THE REPUBLIC OF LATVIA
}

\begin{abstract}
Summary
In 2004 and 2014, the Constitutional Court of the Republic of Latvia has rendered two very important judgments discussing the interrelation between the arbitration and the court of general jurisdiction. The aim of this article is to provide comparative analysis of those judgments and to suggest the necessary improvements for the arbitration law in Latvia as recommended also by the Constitutional Court, but disregarded by the legislator. For example, currently the assistance of the courts of the general jurisdiction in arbitration proceedings is not sufficient in Latvia.
\end{abstract}

Keywords: arbitration, courts assistance in arbitration procedure, Constitutional Court.

\section{Introduction}

In 2014, there were around 214 registered arbitration courts in Latvia. In order to reduce the number of arbitral institutions and to facilitate the trust of arbitration in the society, the Latvian legislator has adopted a new Law on Arbitration Courts that came into force as of 1 January $2015 .^{1}$ As the previous arbitration acts, the Law is not based on UNCITRAL Model Law on International Commercial Arbitration (hereinafter - UNCITRAL Model Law), ${ }^{2}$ thus, there is minimal assistance provided by the state courts in arbitration process. Namely, the state courts are not entitled to perform the functions referred to in Article 6 of the UNCITRAL Model Law, and inter alia set aside procedure is not available in Latvia.

Interaction between courts and arbitration, as well as the need for a wider scope of state courts' assistance in arbitration process have been an issue in practice and it is also reflected in the case law of the Constitutional Court (Satversmes tiesa) of Latvia. In order to better comprehend the notability of these judgments, firstly, author gives a short summary of the facts pertaining to the relevant Constitutional Court's cases, followed by the comparative analysis of the judgments and the impact of those judgments on the arbitration environment of Latvia.

Law on Arbitration Courts: Law of the Republic of Latvia. Latvijas Vēstnesis, 1 October 2014, No. 194.

2 UNCITRAL Model Law on International Commercial Arbitration with amendments 2006. U.N. Doc A/40/17, Annex I, 21 June 1985. 


\section{2004 case of the Constitutional Court ${ }^{3}$}

In the constitutional claim, Limited Liability Company "Asmers" argued that the dispute resolution in the arbitration court cannot be compared with a fair and open adjudication by an independent and impartial court of the general jurisdiction as guaranteed by the Constitution of the Republic of Latvia and the European Convention for the Protection of Human Rights and Fundamental Freedoms. ${ }^{5}$ Thus, an agreement, by which the party waives the right to settle the dispute outside the court, shall not be deemed valid. That is, in the view of "Asmers", the norm providing that a judge shall refuse to accept a statement of a claim and shall terminate proceedings even if "the parties have, in accordance with law, agreed to settle the dispute in an arbitration court" ${ }^{\prime \prime}$ has to be acknowledged as unconstitutional.

In this 2004 case, the Constitutional Court advised that arbitration courts did not belong to the judicial system and could not be considered within the scope of the term "the court." This was argued in the context of the Article 92 of the Constitution stating that "everyone has the right to defend their rights and lawful interests in fair court". Consequently, the rights to settle the dispute in the court of general jurisdiction are not absolute and the parties may waive this right by the signing the arbitration agreement. Basically, the Court confirmed a well-known fact that there were also other means of the dispute resolution than the litigation. Moreover, the courts shall respect the parties' autonomy to choose to settle the disputes outside the courts of general jurisdiction. The arbitration agreement often restricts a party's constitutional and human rights to a public hearing in a court of law. ${ }^{8}$

The constitutional complaint was rejected in the case at hand. However, despite the uncomplicatedness of the grounds of the constitutional complaint, the Constitutional Court gave a valuable contribution to the development of arbitration law in Latvia. For example, this judgment has been one of the most often cited, ${ }^{9}$ especially as concerns the state court's responsibility to assess the compliance

3 On the Compliance of Section 132 (Item 3 of the First Part) and Section 223 (Item 6) of the Civil Procedure Law with Article 92 of the Republic of Latvia Satversme (Constitution): Judgment of the Constitutional Court of the Republic of Latvia in Case No. 2004-10-01 dated 17 January 2005. Latvijas Vēstnesis, 18 January 2005, No. 9.

4 The Constitution (Satversme) of the Republic of Latvia: Law of the Republic of Latvia. Latvijas Vēstnesis, 1 July 1993, No. 43.

5 European Convention for the Protection of Human Rights and Fundamental Freedoms ETS 5, 213 U.N.T.S. 22.

6 See: Art 132(3) and 223(6) of the Civil Procedure Law: Law of the Republic of Latvia. Latvijas Vēstnesis, 3 November 1998, No. 326/330.

7 See: $₫ 5$ of the 2004 Judgment of the Constitutional Court.

8 Kurkela M., Turunen S. Due Process in International Commercial Arbitration. Oxford University Press, 2010, p. 43.

9 See inter alia: Judgment of Supreme Court of the Republic of Latvia in the Case No. SKC-143/2014, 2014; Judgment of Supreme Court of the Republic of Latvia in the Case No. SPC-38, 2012; Judgment of Supreme Court of the Republic of Latvia in the Case No.SPC-10/2008, 2008, etc. 
with due process in arbitral proceedings during the award's execution process. ${ }^{10}$ At that point of time, the average practitioners did not face very complicated problems arising out of arbitration law, thus, also the other possible assistance of the court in arbitration process was not as contemporary a topic in the judgment.

\section{2014 case of the Constitutional Court ${ }^{11}$}

Ten years later, the Constitutional Court again returned to the issue of the competence of the court and arbitration. In the main proceedings, "Hiponia"12 was the respondent in two arbitral procedures in one arbitral institution and the disputes raised from one commercial contract. "Hiponia" insisted that the claim in arbitral court is based on forged arbitration agreement, thus it was not valid. However, the arbitral institution denied the request posed by "Hiponia" for an expertise of the arbitration agreement. Latvian law does not provide for the court's assistance in taking evidence, thus "Hiponia" had no other procedural opportunity to prove this submission. Arbitration Institution made two awards against "Hiponia". However, in parallel with the arbitral proceedings, "Hiponia" requested the court of general jurisdiction to decide upon the validity of the arbitration clause. However, in all three instances the courts decided that they had no competence to decide the matter, as the Article 495 (1) of the Civil Procedure Law clearly stated: "an arbitration court determines the jurisdiction regarding the dispute, even if one of the parties contests the existence or the validity of this agreement." ${ }^{13}$ Viz., in the court practice this norm was interpreted in a way that arbitral tribunal had exclusive competence to decide on its jurisdiction and the court of general jurisdiction could not rule on the invalidity of the arbitration clause in any circumstances. This argument was based on the cited 2004 case of the Constitutional Court, providing that the state should execute the control on arbitrations only at the stage of compulsory execution of the award, not at any other moment. In opposite, it is the author's view that the contested norm of law did not prohibit the challenge of arbitration clause also in the court, however, the courts of the general jurisdiction interpreted this article straightforwardly to reduce the case load of the courts. The author's opinion can also be substantiated by the fact that the contested norm has not been changed even after this judgment of the Constitutional Court.

10 In $\$ 7$ of the Judgment the Constitutional Court stated: "the concept "fair trial" should be attributed also to the arbitration proceedings. In this regard, not only the lack but also doubt of independence and impartiality in the arbitral procedure shall be evaluated. For example, the structure of the arbitration court, previous relations of the arbitrators with the parties, as well as other factors may serve as the reason for such doubt".

11 On Compliance of Section 495(1) of the Civil Procedure Law with the first sentence in Article 92 of the Satversme of the Republic of Latvia. Judgment of the Constitutional Court of the Republic of Latvia in the Case No. 2014-09-01 dated 28 November 2014. Latvijas Vēstnesis, 1 December 2014, No. 238.

12 Previous name of the company: "Hipotēku bankas nekustamā īpašuma agentūra".

13 Civil Procedure Law: Law of the Republic of Latvia. Latvijas Vēstnesis, 3 November 1998, No. $326 / 330$. 
In the case at hand, the Constitutional Court decided that the internationally wellknown principle of the competence - competence does not exclude the possibility that the jurisdiction of an arbitration courts is examined by the court. ${ }^{14}$ Namely, the arbitral tribunal is the first to decide on its jurisdiction but not the last. Thus, the Constitutional Court recognized the contested norm as unconstitutional, insofar as it prohibits from contesting the jurisdiction of arbitral tribunal at a court of general jurisdiction.

As the new Law on Arbitration Courts were adopted at the time of deciding the case, and it contained the same clause as in the Civil Procedure Law, the Constitutional Court also indicated that the particular article is unconstitutional, since it does incorporate the strict, one-step competence - competence principle. It was specifically stressed in the Constitutional Court's judgment that, as concerns "Hiponia", this judgment was of retrospective force. Moreover, the "Hiponia" case was not the only one that landed in the Constitutional Court with similar factual grounds and issues. ${ }^{15}$

Taking into consideration the facts of the case, the Constitutional Court became the last judicial resort for "Hiponia" to challenge the arbitration agreement, therefore it can be concluded that there is a need for the broader scope of courts' of general jurisdiction assistance in arbitration process.

\section{Progressive case law of the Constitutional Court versus legislative reality}

The analyzed judgments of the Constitutional Court contributed to further interpretation of arbitration law in Latvia. Judgments complement each other, and in both cases the Court also examined the issues not covered by the constitutional claims but of importance at the time of deciding the case.

In both cases, the Constitutional Court has recognized that the UNCITRAL Model Law is a standard of arbitration used throughout the world. ${ }^{16}$ Indeed, it is suggested that "the reality is that any seat whose arbitral law is modeled on the UNCITRAL Model Law will likely have legislation which meets the most basic needs." ${ }^{17}$ Even though in the annotation of the new Law on Arbitration Courts it is suggested that the law is based on UNCITRAL Model Law, however, that is not the case in reality, as shown below.

14 See: $\$ 15.5$ of the 2014 Judgment of the Constitutional Court.

15 On Compliance of Section 495(1) of the Civil Procedure Law with the first sentence in Article 92 of the Satversme of the Republic of Latvia. Judgment of the Constitutional Court of the Republic of Latvia in the Case No. 2014-32-01 dated 6 February 2015. Latvijas Vēstnesis, 09 February 2015, No. 27.

16 See: $\$ 9.1$ of the 2004 Judgment of the Constitutional Court and $\$ 15.4$ of the 2014 Judgment of the Constitutional Court.

17 The London Centenary Principles. Chartered Institute of Arbitrators, 2015, $\$ 2$. 
The recently adopted London Centenary Principles ${ }^{18}$ of the Chartered Institute of Arbitrators propose that most likely in those countries, which have not adopted the UNCITRAL Model Law, the legislation framework cannot facilitate fair and just resolution of dispute through the arbitration..$^{19}$ In the author's view, the arbitration seat will be only effective, efficient, predictable and clear, if it provides the appropriate state court's support as set by the UNCITRAL Model Law. For example, currently in Latvia the state courts can grant interim measures but only before commencing the arbitral proceedings ${ }^{20}$ and the judge may issue the writ of execution when the compulsory execution of the arbitral award is requested. ${ }^{21}$ Now, as decided in 2014 case of the Constitutional Court, the courts can rule on the jurisdiction of the arbitral tribunal, but only after the tribunal has done so. No other forms of court's assistance are available under the Latvian law.

There is no set aside procedure available under Latvian arbitration law. This is unacceptable. In both judgments, the Constitutional Court suggested that the legislator shall introduce the set aside of the arbitral award in the law. However, the legislator has not responded to this call. And, indeed, such mechanism is necessary in order to supervise compliance with the fair trial principle in arbitral proceedings; even though it is not a review of the merits, therefore it cannot be considered as appeal. ${ }^{22}$ The purpose of challenging an award before a national court at the seat of arbitration is to have that court declare all, or part, of the award null and void. ${ }^{23}$

In Latvia this necessity was perfectly showed in abovementioned "Hiponia" case, when the respondent to the main arbitration proceedings had no remedy to challenge neither arbitration agreement nor arbitral award. In the case of 2004, the Constitutional Court made an interesting suggestion that " $[\mathrm{i}] \mathrm{n}$ accordance with the general principle, the state is not responsible for violations of the fundamental rights in arbitration court proceedings."24 Yet, further the Constitutional Court suggested that he state still had an obligation not to recognize the result of arbitral proceedings, in which the procedural rights had been violated and in contrast to the greatest number of states, in Latvia the law did not envisage the assistance by the state court in the arbitral proceedings, thus, the control of arbitration courts is concentrated on the stage of issuance of the writ of execution. ${ }^{25}$ However, it is only partially true because in 2014 case the arbitral award did not require a compulsory execution, namely, the award was declaratory and the losing party had no possibility

18 It is a set of ten principles for an effective and efficient seat for the conduct of international arbitration.

19 The London Centenary Principles. Chartered Institute of Arbitrators, 2015, $\$ 2$.

20 Civil Procedure Law: Law of the Republic of Latvia. Latvijas Vēstnesis, 3 November 1998, No. 326/330, Article 139.

${ }^{21}$ Ibid. Article 536.

22 See Article 34 of the UNCITRAL Model Law.

23 Blackaby N. et al. Redferrn and Hunter on International Arbitration. Kluwer Law International, 2015, p. 569.

$24 \$ 9.1$ of the 2004 Judgment of the Constitutional Court.

25 Ibid. 
to object to this award, consequently, the court also could not perform its control over the arbitral award.

It should be added that Latvia is a party to the European Convention on International Commercial Arbitration, ${ }^{26}$ which provides for the mechanism of set aside of the arbitral award. However, in the national law there are no corresponding norms that would allow the parties to use the Convention's mechanism and apply to challenge the arbitral award in the court. Thus, it can be concluded that Latvia does not fulfil the international treaty, to which it is a party.

In addition, currently, even if the enforcement of arbitral award is requested but not granted, the Civil Procedure Law does not state what happens with the arbitral award if the writ of execution is denied. ${ }^{27}$ Namely, if the law is read as it is, the award continues to be valid with power of res judicata because there is no mechanism that would allow to annul the award. Again, this confirms that there is the need for the set aside procedure.

During the procedure in the 2014 case of the Constitutional Court, the representatives of the Parliament (Saeima) argued that by granting a person the right to turn to a court to contest the jurisdiction of an arbitration tribunal would create additional workload to the courts. The Constitutional Court rejected this opinion, stressing that "this argument per se cannot serve as grounds for depriving a person substantially of his or rights. I.e., the aim chosen by the legislator - decreasing the workload of the courts of general jurisdiction, thus speeding up other legal proceedings - may not threaten such fundamental rights of a person that he or she has not voluntarily waived." This argument is different than expressed by the Court in the case of 2004, where it has been stated that the dispute settlement in arbitration shall be facilitated, as it reduces the excessive workload of the courts. ${ }^{28}$ And, indeed, in 2004 the courts received 7378 applications for the compulsory execution of the domestic arbitral awards, and this figure shows the approximate number of the cases heard by the arbitral tribunals. ${ }^{29}$ Therefore, admittedly, if any additional state assistance, including setting aside procedure, existed at that time, it would really overload the courts. However, currently the average number of cases settled by the arbitration has decreased to 979 in 2015, ${ }^{30}$ therefore, also from the practical point of view this argument has lost its validity.

Additionally, it is widely known that the quality of arbitration in the country depends on the educated and professional judges. The London principles provide that the basis for an effective, efficient and "safe" seat for the conduct of arbitration

26 European Convention on International Commercial Arbitration. 484 U.N.T.S. 364, 1961.

27 See Article 536 and 537 of the Civil Procedure Law. Civilprocesa likuma komentāri. III daḷa (61.-86. nodaḷa) (Prof. Torgāna K. red.), TNA, 2014, 165. lpp.

28 \$ 7.2 of the 2004 Judgment of the Constitutional Court, citing European Council Committee of Ministers Recommendation No. R(86)12 Measures to prevent and reduce the excessive workload in the courts, Council of Europe, 1987, p. 6

29 Approximate number because as explained above not all arbitral awards needs compulsory execution or they are recognized and executed abroad.

30 Statistics of Courts Information System for 2004, 2015. Available at https://tis.ta.gov.lv/ tisreal?Form=TIS_STAT_O\&topmenuid=0\&id=94 [last viewed August 22, 2016]. 
is an independent judiciary, competent, efficient, with an expertise in commercial arbitration and respectful of the parties' choice of arbitration as their method for settlement of their disputes. ${ }^{31}$ If the Latvian legislator will adopt UNCITRAL Model law, particular attention should be paid to education of the judiciary on arbitration law, which is the specific field of law.

\section{Conclusions}

The examined Constitutional Court's rulings are a valuable contribution to the development of arbitration law in Latvia. Both judgments of the Constitutional Court discussed above show that issues regarding the interaction between the court of the general jurisdiction and arbitration are topical in Latvia. Although the dimension of the problems differs from those in other countries because Latvia has not accepted the UNCITRAL Model Law but, speaking figuratively, it has invented a new bicycle and is now testing it. However, in author's view, the court's reasonable assistance should be available throughout the arbitration proceedings as provided by the UNCITRAL Model Law. Those notions should be introduced in Latvia to guarantee the fair arbitral procedure, to attract the international players to arbitrate and to make arbitration more predictable in Latvia. But it is rather naïve to hope that the legislator will adopt the UNCITRAL Model Law in the nearest future, however, the Law on Arbitration Courts should provide at least for the set aside of arbitral awards, especially because the Constitutional Court has advised the Parliament twice regarding this need.

\section{BIBLIOGRAPHY}

\section{Literature}

1. Kurkela M., Turunen S. Due Process in International Commercial Arbitration. Oxford University Press, 2010

2. Blackaby N. et al. Redfern and Hunter on International Arbitration. Kluwer Law International, 2015

3. Civilprocesa likuma komentāri. III dạ̦a (61.-86. nodaļa) (Prof. Torgāna K. red.), TNA, 2014

\section{Legislative acts}

1. The Constitution (Satversme) of the Republic of Latvia: Law of the Republic of Latvia. Latvijas Vēstnesis, 1 July 1993, No. 43

2. Law on Arbitration Courts: Law of the Republic of Latvia. Latvijas Vēstnesis, 1 October 2014, No. 194

3. UNCITRAL Model Law on International Commercial Arbitration with amendments 2006. U.N. Doc A/40/17, Annex I, 21 June 1985

31 The London Centenary Principles. Chartered Institute of Arbitrators, 2015, $\$ 2$. 
4. European Convention for the Protection of Human Rights and Fundamental Freedoms ETS 5, 213 U.N.T.S. 22.

5. Civil Procedure Law: Law of the Republic of Latvia. Latvijas Vēstnesis, 3 November 1998, No. 326/330.

6. European Convention on International Commercial Arbitration. 484 U.N.T.S. 364, 1961.

7. The London Centenary Principles. Chartered Institute of Arbitrators, 2015.

8. European Council Committee of Ministers Recommendation No. R(86)12 Measures to prevent and reduce the excessive workload in the courts, Council of Europe, 1987.

\section{Legal practice}

1. On the Compliance of Section 132 (Item 3 of the First Part) and Section 223 (Item 6) of the Civil Procedure Law with Article 92 of the Republic of Latvia Satversme (Constitution): Judgment of the Constitutional Court of the Republic of Latvia in Case No. 2004-10-01 dated 17 January 2005. Latvijas Vēstnesis, 18 January 2005, No. 9.

2. On Compliance of Section 495(1) of the Civil Procedure Law with the first sentence in Article 92 of the Satversme of the Republic of Latvia. Judgment of the Constitutional Court of the Republic of Latvia in the Case No. 2014-09-01 dated 28 November 2014. Latvijas Vēstnesis, 1 December 2014, No. 238.

3. On Compliance of Section 495(1) of the Civil Procedure Law with the first sentence in Article 92 of the Satversme of the Republic of Latvia. Judgment of the Constitutional Court of the Republic of Latvia in the Case No. 2014-32-01 dated 6 February 2015. Latvijas Vēstnesis, 09 February 2015, No. 27.

4. Judgment of Supreme Court of the Republic of Latvia in the Case No. SKC-143/2014, 2014.

5. Judgment of Supreme Court of the Republic of Latvia in the Case No. SPC-38, 2012.

6. Judgment of Supreme Court of the Republic of Latvia in the Case No. SPC-10/2008, 2008. 
Arnis Buka, Dr. iur.

University of Latvia, Latvia

Lolita Berzina, Dr. iur. cand.

University of Latvia, Latvia

\title{
APPLICATION OF THE EU DIRECTIVES IN THE LATVIAN COURTS: TENDENCIES AND CHALLENGES
}

\begin{abstract}
Summary
The paper focuses on directives as a very specific legal instrument of the European Union and their applicability in national courts. The particular emphasis is placed upon various Latvian courts and their case law in the application of the directives. Due to practical reasons, it is impossible to base such research on exhaustive statistical data, therefore authors try to use the most illustrative and topical examples from Latvian case law in order to crystallize general tendencies in the application of directives in Latvian courts and to indicate the most crucial challenges that Latvian courts are facing in this regard.
\end{abstract}

Keywords: European Union law, Latvian courts, directives, implementation, direct and indirect effect.

\section{Introduction}

Directives are a quite unique legal instrument that serves as a perfect sample of interaction between supranational and national levels of the European Union (hereinafter - EU) legal order. At the same time, the nature of directives and the rules regarding their application also might serve as an example of the complexity characteristic to the EU law, as confirmed by the large body of the Court of Justice of the EU (hereinafter - CJEU) case law in this area. So far, the legal doctrine has provided several in-depth studies dedicated to the nature of the directives and their specifics. ${ }^{1}$ Yet there is another aspect of the functioning of the directives - their application at the national level, in particular, by the national courts. This part of the functioning of directives has remained the hidden part of iceberg - practical and theoretical nuances that the national courts encounter in the process of applying directives in legal science has been touched upon only briefly (both at the EU ${ }^{2}$ and

See, e.g., Prechal S. Directives in EC Law, $2^{\text {nd }}$ edition. Oxford: Oxford University Press, 2005.

2 See, e.g., Summary report of a survey on the knowledge of EU law among Dutch and German judges "The court is not so sure about the law - national judges and EU law". Available at http:// legalresearchnetwork.eu/wp-content/uploads/2011/10/PaperTobiasNowakGroningen.doc [last viewed August 30, 2016]. 
at the Latvian ${ }^{3}$ level). At the same time, the role of the national courts in proper functioning of the EU law cannot be denied.

However, the ambition of the paper does not extend so far as to give a thorough analysis on the application of the directives in all cases when Latvian courts have done it or should have done it. As Latvian courts produce tens of thousands of judgments and decisions annually, conduct of such a research would be highly challenging due to the extensive amount of information and research difficulties. ${ }^{4}$ Instead, the paper focuses mostly on the judgments of the Latvian Supreme Court and, in particular, on those judgments that the court itself has pointed out as the most important and published. Furthermore, interviews with legal practitioners and judges have also been used as an additional source of information. Thus, the aim of the paper is to acknowledge and to generalize, within the limits of viable information, the most topical issues in regarding application of directives by the Latvian courts.

The structure of the paper reflects this aim and consists of two main parts. The first part briefly outlines the specific nature of directives in the EU law and the respective CJEU case law in that regard (well-known for the EU law specialists, yet necessary as a point of departure for further elaboration). The second, more extensive part of the paper shifts the focus to the Latvian courts by unfolding the differences between various courts and cases in the context of applying directives and by identifying the most topical particular issues in the context of directive application by the Latvian courts.

\section{Directives in the EU law}

The Article 288 of the Treaty on Functioning of the European Union (hereinafter TFEU) enlists the kinds of legal acts the EU institutions can adopt to exercise their competences. The third part of the Article refers specifically to directives and explains their role within the legal system of the EU: "A directive shall be binding, as to the result to be achieved, upon each Member State to which it is addressed, but shall leave to the national authorities the choice of form and methods."

3 On the application of EU law in Latvia in general see, e.g.: Žukova G. The application of EU law in Latvia. In: Łazowsk A. (ed.). The application of EU law in the new member states. The Hague: T.M.C. Asser Press, 2010, pp. 243-276 and more recent research: Kačevska I., Rudevska B., Buka A., Dambergs M., Fillers A. The Court of Justice of the European Union and the impact of its case law in the area of civil justice on national judicial and administrative authorities (Latvia, Hungary, Germany, Sweden and the United Kingdom). Riga: Ministry of Justice, 2015.

4 The huge range of practical problems connected with such task is also noticed by other legal scientists. For example, S. E. Strasser states that "receiving adequate and accurate information on just how Community law is being used by judges in the Member States may prove difficult" see Strasser, S. E. Evolution \& Effort: The Development of a Strategy of Docket Control for the European Court of Justice \& the Question of Preliminary References. Monnet Center Research paper. Available at www.jeanmonnetprogram.org/papers/95/9503ind.html [last viewed August 30, 2016]. 
In other words, directives are normative acts addressed to the Member States, which are then required to adopt the necessary national provisions to give effect to the policy objectives set out in the directive. ${ }^{5}$ Therefore, the choice of forms and methods to reach the goal set in the directives is left to the governments and institutions of Member States. Consequently, it can be said that the nature of the directives is a compromise between the binding law adopted by the EU singlehandedly, such as regulations, and the margin of appreciation of Member States. ${ }^{6}$ The reality at times, however, is somewhat different. The rules of the directives, especially in areas where the regulated matter is mainly technical, sometimes leave a quite narrow space for manoeuvres of Member States even regarding the forms and methods. Some authors attribute it to the EU's thirst for power, while others point towards the mistrust among the Member States themselves. ${ }^{7}$ Namely, almost all the Member States at some point have been found guilty of improper transposition or implementation of a directive. The more detailed the directive, the less space for margin of appreciation and consequently - for misapplication of the directive on behalf of Member States.

The CJEU has also dealt with improper transposition and/or implementation of the directives by the Member States. It has found that the national courts are in the best position to remedy a situation where a Member State has transposed a directive erroneously or has not done it at all. The CJEU has emphasized several duties of the courts of Member States in this regard.

Firstly, national courts are under obligation to apply the norms of the directive directly, if certain conditions are met. Those conditions include the general requirements that all EU law norms should be fulfilled in order to have a direct effect (norms should be precise, clear, unconditional and should not call for additional measures), as well as the specific preconditions regarding directives and their period of implementation. Namely, directives can be directly effective only when the Member State has not transposed the directive by the deadline. Additionally, the directives can be applied directly only in cases where respondent can be regarded as the state institution. ${ }^{8}$ Direct application of the directives against private parties is not permitted, although CJEU has allowed the so-called incidental direct effect of directives in cases where the state's failure to comply can be an incidental factor in a lawsuit against an individual. ${ }^{9}$

Situation is made even more complicated by additional developments of the CJEU case law that introduced concepts of indirect effect and state liability.

Barnard C., Peers S. (eds.). European Union Law. Oxford: Oxford University Press, 2014, p. 100.

Streinz R. Europarecht. 9. neu bearbeitete Auflage. Hemsbach: C. F. Müller, 2012, p. 165.

For Barnard C., Peers S. (eds.). European Union Law. Oxford: Oxford University Press, 2014, pp. $100-102$.

8 CJEU judgment of 4 December 1974 in Case No. 41/74 Van Duyn.

9 CJEU judgment of 30 April 1996 in Case No. C 194/94 CIA Security; See also Lackhoff K., Nyssens H. Direct Effect of Directives in Triangular Situations. European Law Review, 1998, No. 5, pp. 397-413. 
Indirect effect, in essence, means that "when national courts apply domestic law they are bound to interpret it, so far as possible, in the light of the wording and the purpose of the directive concerned in order to achieve the result sought by the directive and consequently comply with the third paragraph of Article 288 TFEU." ${ }^{10}$ Even though direct effect has been the subject of arguably more publications, it has been contended that the indirect effect has been deployed by national courts more often $^{11}$ - an impression that seems true in regard to Latvian courts, as well.

An aspect sometimes discussed as a part of indirect effect ${ }^{12}$ and sometimes seen as a separate issue ${ }^{13}$ is the question whether the states had any obligations arising from the directives also before the deadline of the transposition of a directive. On the one hand, the CJEU has ruled that "during the period prescribed for transposition of a directive, the Member States to which it is addressed must refrain from taking any measures liable seriously to compromise the attainment of the result prescribed by it” ${ }^{14}$ At the same time, the CJEU itself has taken the opposite side in several decisions noting that the Member States had not violated EU law by disregarding directives, which are yet to be implemented, ${ }^{15}$ thereby creating legal uncertainty in this regard. Finally, state liability, in turn, provides financial remedies, if the Member State fails to fulfil the EU law requirements. The conditions of the state liability are quite similar to the ones used to determine non-contractual (tortuous) liability: 1) a sufficiently serious wrong of a legal provision which was intended to confer rights on individuals, 2 ) damage and 3) causal link between the wrong and the damage. ${ }^{16}$

\section{Application tendencies: variations among different courts and cases}

Latvian court system consists of separate administrative courts, as well as courts of general jurisdiction that, in their turn, handle both civil and criminal cases. ${ }^{17}$ For the purposes of the paper, slightly different tendencies can be noted if one compares

10 CJEU judgment of 24 January 2012 in Case No. C-282/10, Dominguez, para. 24.

11 Chalmers D., Davies G., Monti G. European Union Law: Text and Materials. Third edition. Cambridge: Cambridge University Press, 2014, p. 316.

12 Schewe C., Buka A., Gailītis K., Srazdinš̌ G̦. Eiropas Savienības tiesības: I dal̦a, Institucionālās tiesības. Rìga: Tiesu namu aǵentūra, 2014, 248. - 250. lpp.

13 Chalmers D., Davies G., Monti G. European Union Law: Text and Materials. Third edition. Cambridge: Cambridge University Press, 2014, pp. 323-325.

14 CJEU judgment of 4 July 2006 in Case No. C-212/04 Adeneler, para. 122.

15 CJEU judgment of 10 May 2011 in Case No. C-147/08 Römer and CJEU judgment of 26 May 2011 in Case No. C-165/09 Stichting Natuur en Milieu and Others.

16 See e.g.: CJEU judgment of 19 November 1991 in joined Cases No. C-6/90 and C-9/90 Francovich ; CJEU judgment of 5 March 1996 in joined Cases No. C-46/93 and C-48/93 Brasserie du Pêcheur/ Factortame.

17 The Supreme Court and the Latvian Court System. Available at http://at.gov.lv/en/about-thesupreme-court/organization/the-supreme-court-and-the-latvian-court-system/ [last viewed August 30, 2016]. 
the application of directives in administrative, civil and criminal cases. Additional few remarks will be addressed towards Latvian Constitutional Court.

Yet, before turning to some tendencies that can be noted by dividing cases into administrative, civil and criminal, there are two preliminary remarks to be made. Firstly, it should be noted that the level in the hierarchy of courts also matters in the context of the application of directives. Since 1995, there have been three levels of courts in Latvia. The first level courts are the district (city) courts; the second level is the regional courts and the third level is the Supreme Court. ${ }^{18}$ In the context of the application of the directives, the distinction between lower courts and the Supreme Court is quite substantial in the terms of quality of the application as well as in terms of readiness to use the EU law in general. This is also verified by the fact that the vast majority of the requests for the preliminary rulings from Latvian courts is coming from the Latvian Supreme Court. ${ }^{19}$

Secondly, Latvia is a leading country in implementing the EU law - so far, during $12 \mathrm{EU}$ membership years there has been only a single case in the CJEU against Latvia under Article 258 TFEU for breaching the EU law obligations. ${ }^{20}$ As a consequence, it is fairly safe to presume that the vast majority of Latvian laws indeed are in conformity with the directives. This leads to the situation that parties of the case seldom can benefit from obvious contradictions between the directive and the Latvian law. And this, in turn, might be one of the factors why Latvian judges and other legal practitioners do not use directives too often.

\subsection{Administrative cases}

Administrative courts that adjudicate administrative cases have to deal with the EU directives most often. As can be seen from the areas in which the CJEU receives the most questions for the preliminary rulings, this tendency is similar throughout the entire EU. ${ }^{21}$ However, in Latvia the administrative courts are the ones leading the application of directives not only in quantity but in quality, as well. There are numerous judgments from the Supreme Administrative Court that have dealt with the application of the EU directives and usually the court has not only correctly

18 The Supreme Court and the Latvian Court System. Available at http://at.gov.lv/en/aboutthe-supreme-court/organization/the-supreme-court-and-the-latvian-court-system/ [last viewed August 30, 2016].

19 By the end of 201432 out of total 37 requests were made by the Latvian Supreme Court (the CJEU report provides incorrect data in this regard, most likely by counting Latvijas Augstākās tiesas Senäts (Senate of the Supreme Court of Latvia) as one of the lower courts) - see: Court of Justice of the European Union, Annual report 2014. Luxembourg, 2014. p. 118. Available at http://curia. europa.eu/jcms/upload/docs/application/pdf/2015-03/en_ra14.pdf [last viewed August 30, 2016].

20 Court of Justice of the European Union, Annual report 2014. Luxembourg, 2014, p. 118. Available at http://curia.europa.eu/jcms/upload/docs/application/pdf/2015-03/en_ra14.pdf [last viewed August 30, 2016].

21 See statistics on national courts that make references and on areas that the references are made on: Court of Justice of the European Union, Annual Report 2014. Luxembourg, 2014. Available at http://curia.europa.eu/jcms/upload/docs/application/pdf/2015-03/en_ra14.pdf [last viewed August 30, 2016]. 
applied the directives in question, but also connected them with the relevant CJEU case law and initiated the preliminary rulings procedure when necessary.

Even more, in some judgments the Supreme Administrative Court has deployed quite extensive argumentation not only regarding particular directives in question, but also elaborated on the explanation of general principles on how the directives should be used by Latvian courts. The best example of this is the case SKA-293/2010 regarding individuals, who have subjective right to lodge a complaint challenging the result of public procurement procedure. ${ }^{22}$ In this case, the applicant was "Biznesa augstskola Turiba", an educational establishment that did not receive the public procurement contract of the State Employment Agency to organize a training for the unemployed. The applicant challenged the legality of contract that the State Employment Agency concluded with another provider of educational services, who won the public procurement in question. However, Latvian law on public procurement at the time limited the admissibility of such challenges before administrative courts - the applicant had the burden of proof to show that its subjective rights and interests were violated by the public procurement procedure. As a result, the losing contenders in public procurement could not directly challenge in courts the contracts awarded to other contenders. The only possible route was to challenge the decision of the contract awarding authority (but not the contract itself), and in this case the very short ten-day time limit for this procedure had expired.

The courts of the first two instances dismissed the application as inadmissible. Yet, the Latvian Supreme Administrative Court found that the application should be admissible and based their argumentation to a large extent on the EU public procurement directives. The court argued that the concept of "subjective rights" in this case should be interpreted broadly, taking into account the definitions supplied by the EU directives. Even more, in this decision of the Supreme Administrative Court provided a genuinely detailed argumentation on the direct effect of directives, especially pointing out that the relations in question can be regarded as a case where the vertical direct effect of directives can be applied.

\subsection{Civil cases}

Compared to administrative cases, in civil cases the EU law-related case law can be found relatively seldom. Even more, a large part of that rare case law relates to international private law issues that are governed by the EU regulations and thus falls outside of the scope of present paper. ${ }^{23}$ Nonetheless, application of directives in civil

22 Judgment of the Administrative Department of the Supreme Court of the Republic of Latvia March 24, 2010 in the Case No. SKA-293/2010.

23 The analysis on various aspects of Latvian case law in that area can be found in a separate research: Kačevska I., Rudevska B., Buka A., Dambergs M., Fillers A. The Court of Justice of the European Union and the impact of its case law in the area of civil justice on national judicial and administrative authorities (Latvia, Hungary, Germany, Sweden and the United Kingdom). Riga: Ministry of Justice, 2015. 
cases is a fruitful ground for inquiries about the readiness of Latvian courts to deal with the complicated concept of indirect effect of the EU law.

As a general rule, Latvian courts in civil cases usually avoided express usage of the terms "direct effect" or "indirect effect", but instead just used directives in conjunction with the relevant Latvian law. ${ }^{24}$ However, recent judgment by the Latvian Supreme Court confirmed how confusing an application of those EU law concepts can be in practice.

The case originated with a civil claim by "Société des Produits Nestlé S.A." (hereinafter - "Nestle") against limited liability company named "Sara Lee Baltic" (hereinafter - "Sara Lee") regarding the use of the "Red cup" trademark registered by "Nestle". "Nestle" accused "Sara Lee" of illegal use of its trade mark and required it to pay compensation in the amount of 26716,44 lats (approximately 38014.29 euro), which would be the amount "Sara Lee" would pay "Nestle", if "Sara Lee" would have bought the right to use the trademark from "Nestle" (the so-called license fee).

After several judgments and appeals, the case was brought before the Chamber of Civil Cases of the Supreme Court (at that time the court of second instance). ${ }^{25}$ It stated that the Law on Trade Marks and Indications of Geographical Origin at the time of the dispute did not provide the license fee as a type of compensation to be paid in these kinds of cases. Although "Nestle" argued that the Directive 2004/48/EC provided for this kind of compensation, the Court argued that it is not applicable in this case. It based its argumentation on several arguably questionable findings. The one illustrating the aforementioned issue with the misunderstanding of the consequences of deadline of the transposition is the following: the Court stated that before the deadline of the transposition of the particular directive it could not create any legal effects whatsoever. The court did not mention neither direct nor indirect effect of the directives, but its argumentation in essence was devoted to proving that the direct effect was not present in this case.

Consequently, the Department of Civil Cases of the Supreme Court annulled the judgment. ${ }^{26}$ It pointed out that this is the case of indirect effect of directives and that the Law on Trade Marks and Indications of Geographical Origin had to be interpreted in the light of the particular directive as the deadline of the implementation of the directive had passed in the middle of period when "Sara Lee" misused the trade mark of "Nestle". The Court also added that when the legislation failed to implement a directive, the courts, when asked to interpret national law, must interpret it as far as possible in conformity with the substance and aim of the directive.

In this case, the directive in question was transposed in Latvian legislation approximately a year after the deadline of its transposition. The previously analyzed

24 See, e.g., Judgment of the Civil Department of the Supreme Court of the Republic of Latvia of 28 November 2012 in Case No. SKC-392/2012.

25 Judgment of the Chamber of Civil Cases of the Supreme Court of the Republic of Latvia of 16 October 2012 in Case No. C04292106

26 Judgment of the Civil Department of the Supreme Court of the Republic of Latvia of 9 December 2015 in Case No. SKC-96/2015. 
case serves as an example illustrating how a seemingly unimportant delay combined with at times misleading case law of the CJEU can lead to a particularly difficult situation for the involved parties, and, as can be concluded by the many decisions in the case and its length, present challenges for the judges, as well. It must be noted, however, that the Civil Department of the Supreme Court by referring to several rulings of the CJEU has solved the issue rather clearly.

\subsection{Criminal cases}

So far, the influence of the EU directives on Latvian case-law in criminal cases can be seen as marginal at best - it is really hard to find even an indirect mention of the directives in criminal cases. Moreover, in those few criminal cases that actually make references to the directives, it is easy to glimpse uncertainty and cautiousness with which the Latvian courts treat the EU law instruments, especially in older cases. For example, in case regarding the driving documents forgery, the Criminal Division of the Supreme Court just mentioned the existence of the directives on the registration of vehicles, but even did not bother to point out anything to characterise what those directives contain or how they relate to particular case. ${ }^{27}$ Additionally, there are several examples of some minor technical problems with the references to the EU law (e.g., some massively copied references to the CJEU case law from other sources, although this fault can be found in some civil and administrative cases, as well). In another criminal case, the court of the first instance confused the names of the EU law instruments and named the directives in question as regulations. ${ }^{28}$

Nonetheless, it is realistic to expect a dramatic increase of the role of the directives in criminal cases in nearest future due to the end of transitional period relating to EU criminal law measures adopted before the entry into force of the Lisbon Treaty and even more as the Lisbon treaty conferred notable increases in legislative power for the EU in criminal law matters. ${ }^{29}$ As a result, there are several post-Lisbon directives in the sphere of criminal law whose transposition periods have ended or are ending. Perhaps among the most important in this regard is the directive establishing minimum standards for the rights, support and protection of victims of crime (hereinafter - Victim Directive), ${ }^{30}$ which has already played a noticeable role in Latvian courts.

27 Judgment of the Criminal Department of the Supreme Court of the Republic of Latvia of 9 May 2013 in Case No. SKK-165/2013.

28 Reference to this judgment of the court of first instance can be found in the Judgment of the Criminal Department of the Supreme Court of the Republic of Latvia of 30 October 2014 in Case No. SKK-545/2014.

29 On this see, e.g., Craig P., de Burca G. EU Law. Text, Cases and Materials. $5^{\text {th }}$ edition. Oxford: Oxford University Press, 2011, pp. 940-946; Peers S. Childhood's End: EU criminal law in 2014. Available at http://eulawanalysis.blogspot.com/2014/12/childhoods-end-eu-criminal-law-in-2014. html [last viewed August 30, 2016].

30 Directive 2012/29/EU of the European Parliament and of the Council of 25 October 2012 establishing minimum standards on the rights, support and protection of victims of crime, and replacing Council Framework Decision 2001/220/JHA. OJ L 315, 14.11.2012, pp. 57-73. 
An eminent criminal case in the recent years is connected with one of the most tragic accidents in the history of Latvia. On November 23, 2013, a building housing supermarket "Maxima" collapsed in Riga and 54 people lost their lives in the tragedy. ${ }^{31} \mathrm{~A}$ criminal case was initiated after these tragic events. The first hearing in the case took place on December 8, 2015. To date, the court has not commenced hearing the substance of the case, but has dealt with the great amount of requests, including the requests of relatives of the deceased to be recognized as victims in the case.

Article 27 of the Victim Directive provides: "Member States shall bring into force the laws, regulations and administrative provisions necessary to comply with this Directive by 16 November 2015”. Inter alia, the directive recognises that the person who was living with the deceased person in a committed intimate relationship, in a joint household and on a stable and continuous basis and the dependants of the victim should be considered victims. ${ }^{32}$

One of the hearings in the "Maxima" case took place on March 1, 2016. A woman who had lived together with one of the deceased in the tragedy, asked the court hearing the case to be recognized as a victim. The court rejected the claim, ${ }^{33}$ as the Criminal Procedure Law in force at the time provided that only the surviving spouse, one of the ascending or descending relatives of the deceased, or the adopter or a collateral relative of the first degree of such deceased could be recognized as victims. The Victim Directive was transposed and the Criminal Procedure Law was amended on March 23, 2016.

This decision deserves severe critique. Apparently, it fails to notice that the deadline for transposition of the Victim Directive had already passed and therefore the national courts of the Member States are obliged to interpret national law within the light of the aim of the directive. Even more, the amendments of the Criminal Procedure $\mathrm{Law}^{34}$ were already available at the day of the decision indicating the wish of the legislator to comply with the Victim Directive.

\subsection{Latvian Constitutional Court}

Finally, the role of the EU directives in the judgments of the Latvian Constitutional Court also deserves a brief insight. Although so far the Latvian Constitutional Court has made no references to the CJEU in the preliminary rulings, nonetheless, as early as 2008 , in one of the judgments in the context of the interpretation of Latvian law

31 The events regarding the Maxima tragedy were reported by the media widely. See e.g. Latvia mourns victims of Riga supermarket collapse. BBC News, 23 November 2013. Available at http://www.bbc. com/news/world-europe-25058017 [last viewed August 30, 2016].

32 Directive 2012/29/EU of the European Parliament and of the Council of 25 October 2012 establishing minimum standards on the rights, support and protection of victims of crime, and replacing Council Framework Decision 2001/220/JHA. OJ L 315, 14.11.2012, pp. 57-73, Article 2.

33 The decision is not publicly available. Source of information: Interview with legal practitioner representing one of the parties Jevgenija Tverjanoviča - Bore (Riga, 15 March 2016), materials from the personal archive of A. Buka.

34 Grozījumi Kriminālprocesa likumā: LR likums. Latvijas Vēstnesis, 2016. 9. marts, Nr. 48. 
that was based on the implemented EU directive, the Latvian Constitutional Court affirmed readiness to make the reference in the preliminary ruling. Even more, the Latvian Constitutional court was one of the rare constitutional courts who expressly admitted that considering themselves as "court or tribunal of a Member State against whose decisions there is no judicial remedy under national law" within the meaning of the Article 267 (3) of the TFEU and, therefore, were subject to the obligation to make the reference to the CJEU. ${ }^{35}$

However, at the same time, the Latvian Constitutional Court is somewhat evasive in relation to the EU law and there are no judgments that would directly declare invalidity of the Latvian law only because it is not compatible with the directive or any other EU law instrument. In one of the recent cases, the Latvian Constitutional Court actually did that in substance, however, without expressly stating it. ${ }^{36}$

The case concerned the compliance of several provisions in the Regulation by the Cabinet of Ministers (hereinafter - Regulation) that establish the amount of insurance indemnity and the procedure for calculating it for non-material losses caused to a person with Constitution. It was brought to the Constitutional Court by the Civil Department of the Supreme Court, which considered that the amounts of insurance indemnity envisaged by the contested norms were incommensurably small. In a case before the Supreme Court, the claimant - a minor - had lost both parents in a road traffic accident. He had received the insurance indemnity for the loss of a breadwinner in the amount stipulated by the contested norm, i.e., 100 lats (approximately 142 euro) for each breadwinner, while the requested sum was 200000 lats (approximately 284575 euro). In the application to the Constitutional Court, the Supreme Court noted that a court of general jurisdiction could not, in the case of compulsory civil liability insurance of motor vehicle owners, set the amount of compensation for non-material losses from the insurer that would exceed the one defined in the contested norms, that is, the 200 lats the insurer had already paid.

Already the Supreme Court noted that the case also touches upon aspects of EU law. Namely, the Compulsory Civil Liability Insurance of Owners of Motor Vehicles Law (hereinafter - the OCTA Law), which delegated the Cabinet of Ministers to issue the contested Regulation, was also the law implementing several EU directives in the field. The aim of these directives was to harmonize the field of compulsory civil liability insurance and one of them set the minimum amount of the insurance indemnity to be paid in case of an accident.

The Constitutional Court concluded that the contested Regulations must comply with the norms of the OCTA Law, which implement the EU directives. Notably, it was not expressis verbis mentioned that the regulations must comply with

35 Judgment of the Constitutional Court of the Republic of Latvia of 2 June 2009 in Case No. 2008-47-01, para. 15.2. English translation available at http://www.satv.tiesa.gov.lv/ wp-content/uploads/2008/11/2008-47-01_Spriedums_ENG.pdf [last viewed August 30, 2016].

36 Judgment of the Constitutional Court of the Republic of Latvia of 29 December 2014 in Case No. 2014-06-03. 
the directives themselves, however, in the judgment the Constitutional Court analysed exactly that.

The Constitutional Court started by arguing that the Member States are obliged to transpose all the parts of any directive in their legal systems and that this duty falls upon both the legislative and executive powers of the states. Therefore, if the legislator has authorised the executive branch to regulate a particular field, as, in this case, the OCTA Law delegated the Cabinet of Ministers to determine the exact amounts of insurance indemnity to be paid in particular situations, also the executive branch had to comply with the directives in the field. Since the Constitutional Court found that the amount of insurance indemnity set by the contested Regulation was much smaller than the amount of insurance set by the aforementioned EU directives, it ruled that the Regulation is not compatible with OCTA Law.

The Constitutional Court might have several reasons, maybe even including rather political ones, not to openly analyse the national law's compliance with the EU law. Nevertheless, in the particular case the main reason could be quite simple. Namely, in its application to Constitutional Court the Supreme Court had not questioned the compatibility of the Regulation with the EU directives and the Constitutional Court was under limitations to act on its own notion.

\section{Conclusions}

The Latvian administrative courts apply directives more often, with a better argumentation and in well-grounded manner in comparison with the courts hearing civil and criminal cases. One of the possible reasons why Latvian administrative courts are more ready to work with the EU directives is that Latvian administrative courts were created as new, separate courts pretty much simultaneously with Latvia's accession to the EU, and from the very beginning these courts were composed from open-minded judges with a sufficient EU law knowledge.

High standards of Latvian government in implementing the directives leads to very few cases, were the direct effect of directives is used and reduces the necessity to make references to the directives in general. However, it must be noted that there is still a place for improvement in this regard also for the Latvian government, as in several occasions it has transposed directives belatedly, which is leading to complicated law-suits in Latvian courts.

Another slight ambiguity that stems from the judgments of Latvian courts is the tendency to magnify the importance of the transposition deadline. So far, Latvian courts have treated transposition date as a "set in stone" prerequisite for a directive to have any legal effect on private parties. As is explained in detail within the early parts of this paper, this is generally a correct reflection of the CJEU position. Yet problems here can arise in cases when Latvian legislator adopts national legal measures that contravene the aim of the directive and in such cases the directive can have the effect even before the transposition deadline. However, again referring to the outstanding performance by Latvian legislators in ensuring the compliance of the Latvian law 
with the EU law, such cases are a rarity and in the majority of them Latvian judiciary is able to adjudicate them correctly.

Finally, the analysis of Latvian case law in relation to directives found no examples where somebody had tried to claim state liability due to the damages that were caused by state failing to implement EU law. Again, the reference to highly successful implementation rate might be an answer here. Yet, at the same time, a total vacuum in this regard might be sending signals that Latvian procedural laws are setting overly high prerequisites for such claims and making them virtually impossible.

\section{BIBLIOGRAPHY}

\section{Literature}

1. Barnard C., Peers S. (eds.). European Union Law. Oxford: Oxford University Press, 2014, p. 100.

2. Chalmers D., Davies G., Monti G. European Union Law: Text and Materials. Third edition. Cambridge: Cambridge University Press, 2014.

3. Craig P., de Burca G. EU Law. Text, Cases and Materials. 5th edition. Oxford: Oxford University Press, 2011.

4. Kačevska I., Rudevska B., Buka A., Dambergs M., Fillers A. The Court of Justice of the European Union and the impact of its case law in the area of civil justice on national judicial and administrative authorities (Latvia, Hungary, Germany, Sweden and the United Kingdom). Rìga: Ministry of Justice, 2015.

5. Lackhoff K., Nyssens H. Direct Effect of Directives in Triangular Situations. European Law Review, 1998, No. 5.

6. Latvia mourns victims of Riga supermarket collapse. BBC News, 23 November 2013. Available at http://www.bbc.com/news/world-europe-25058017 [last viewed August 30, 2016].

7. Peers S. Childhood's End: EU criminal law in 2014. Available at http://eulawanalysis.blogspot. com/2014/12/childhoods-end-eu-criminal-law-in-2014.html [last viewed August 30, 2016].

8. Prechal S. Directives in EC Law $2^{\text {nd }}$ edition. Oxford: Oxford University Press, 2005.

9. Schewe C., Buka A., Gailītis K., Srazdiņ̌̌ G̦. Eiropas Savienības tiesības: I daļa, Institucionālās tiesības. Rìga: Tiesu namu ağentūra, 2014.

10. Strasser, S.E. Evolution \& Effort: The Development of a Strategy of Docket Control for the European Court of Justice \& the Question of Preliminary References. Monnet Center Research paper. Available at www.jeanmonnetprogram.org/papers/95/9503ind.html [last viewed August 30, 2016].

11. Streinz R. Europarecht. 9. neu bearbeitete Auflage. Hemsbach: C. F. Müller, 2012.

12. Žukova G. The application of EU law in Latvia. In: Łazowsk A. (ed.). The application of EU law in the new member states. Book. The Hague: T.M.C. Asser Press, 2010.

\section{Legislative acts}

1. Directive 2012/29/EU of the European Parliament and of the Council of 25 October 2012 establishing minimum standards on the rights, support and protection of victims of crime, and replacing Council Framework Decision 2001/220/JHA. OJ L 315, 14.11.2012, pp. 57-73.

2. Grozījumi Kriminālprocesa likumā: LR likums. Latvijas Vēstnesis, 2016. 9. marts, Nr. 48. 


\section{Legal practice}

1. CJEU judgment of 4 December 1974 in Case No. 41/74 Van Duyn.

2. CJEU judgment of 19 November 1991 in joined Cases No. C-6/90 and C-9/90 Francovich.

3. CJEU judgment of 5 March 1996 in joined Cases No. C-46/93 and C-48/93 Brasserie du Pêcheur/Factortame.

4. CJEU judgment of 30 April 1996 in Case No. C 194/94 CIA Security.

5. CJEU judgment of 4 July 2006 in Case No. C-212/04 Adeneler.

6. CJEU judgment of 10 May 2011 in Case No. C-147/08 Römer.

7. CJEU judgment of 26 May 2011 in Case No. C-165/09 Stichting Natuur en Milieu and Others.

8. CJEU judgment of 24 January 2012 in Case No. C-282/10, Dominguez.

9. Judgment of the Constitutional Court of the Republic of Latvia of 2 June 2009 in Case No. 2008-47-01.

10. Judgment of the Constitutional Court of the Republic of Latvia of 29 December 2014 in Case No. 2014-06-03.

11. Judgment of the Administrative Department of the Supreme Court of the Republic of Latvia of 24 March 2010 in the Case No. SKA-293/2010.

12. Judgment of the Civil Department of the Supreme Court of the Republic of Latvia of 28 November 2012 in Case No. SKC-392/2012.

13. Judgment of the Criminal Department of the Supreme Court of the Republic of Latvia of 9 May 2013 in Case No. SKK-165/2013.

14. Judgment of the Criminal Department of the Supreme Court of the Republic of Latvia of 30 October 2014 in Case No. SKK-545/2014.

15. Judgment of the Civil Department of the Supreme Court of the Republic of Latvia of 9 December 2015 in Case No. SKC-96/2015.

16. Judgment of the Chamber of civil cases of the Supreme Court of the Republic of Latvia of 16 October 2012 in Case No. C04292106.

\section{Other sources}

1. Court of Justice of the European Union, Annual report 2014. Luxembourg, 2014. Available at http://curia.europa.eu/jcms/upload/docs/application/pdf/2015-03/en_ra14.pdf [last viewed August 30, 2016].

2. Interview with legal practitioner representing one of the parties Jevgenija Tverjanoviča-Bore (Riga, 15 March 2016), materials from the personal archive of A. Buka.

3. Summary report of a survey on the knowledge of EU law among Dutch and German judges "The court is not so sure about the law - national judges and EU law". Available at http:// legalresearchnetwork.eu/wp-content/uploads/2011/10/PaperTobiasNowakGroningen.doc [last viewed August 30, 2016].

4. The Supreme Court and the Latvian Court System. Available at http://at.gov.lv/en/about-thesupreme-court/organization/the-supreme-court-and-the-latvian-court-system/ [last viewed August 30, 2016]. 
Christoph Schewe, Dr. iur.

University of Latvia, DAAD, Latvia/Germany

\title{
IS THE TIIP AN ASSAULT ON THE RULE OF LAW ?
}

\begin{abstract}
Summary
The latest generation of trade and investment agreements currently negotiated by the EU (TTIP and CETA) is frequently criticised as an "attack on democracy and the rule of law". At the same time, the negotiators claim the opposite - that TTIP is in line with the rule of law ${ }^{1}$ and would even promote respective standards. ${ }^{2}$ The paper intends to explain these contradictory statements, providing the relevant background information of the TIIP and further explores, in how far the statements are founded.

Accordingly, the paper firstly discusses how trade and investment agreements interact with national law before elaborating on the question what is to be understood under the term rule of law in this context. Subsequently, it identifies the main elements and effects associated with it, differentiating between the national and international levels. In the second step the paper examines the mechanism, through which trade agreements may contribute to enhancing the rule of law in the contracting states. The article concludes with the discussion, how far the elements of trade and investment agreements that are said to aim at securing the rule of law, correspond to the expectations to this principle. Here the paper highlights the potential conflict with other values, particularly with democratic decisions taken on a national level and the rule of law in the national state (Rechtsstaat).
\end{abstract}

Keywords: Trade and investment, international law, rule of law, Rechtsstaat, TTIP, CETA.

\section{Introduction}

A popular newspaper article published in DIE ZEIT in 2014 headed "TTIP ist ein Angriff auf Demokratie und Rechtsstaat" [TTIP is an attack on democracy and the rule of law]. ${ }^{3}$ The website of the European Commission, DG Trade, however, stated the opposite, claiming that TTIP would promote the rule of law. The present contribution will shed some light on these contradictory statements,

Karel De Gucht/European Commission, TTIP and the Investment Dimension: What is the State of Play? 24 June 2014, Press release. Available at http://europa.eu/rapid/press-release SPEECH-14-494_en.htm [last viewed September 12, 2016].

2 European Commission, European Commission Fires Starting Gun for EU-US Trade Talks, Press release, Brussels, 12 March 2013. Available at http://europa.eu/rapid/press-release_IP-13-224en. htm [last viewed September 12, 2016].

3 Pinzler P. Freihandelsabkommen: "TTIP ist ein Angriff auf Demokratie und Rechtsstaat", Interview with Klaus Staeck, Die Zeit, 14 May 2014. Available at http://www.zeit.de/wirtschaft/ 2014-05/interview-staeck; also see: Petra Pinzler, Wolfgang Uchatius und Kerstin Kohlenberg, Schattenjustiz: Im Namen des Geldes, DIE ZEIT No. 10/2014, 27. Februar 2014, available at http://www.zeit.de/2014/10/investitionsschutz-schiedsgericht-icsid-schattenjustiz [last viewed September 12, 2016]. 
explaining the relevant background of the TIIP and further examine, to what extent the statements are founded.

The debate on trade and investment agreements has to be seen in the context of the increasing juridification of international trade in the $20^{\text {th }}$ century, most prominently leading to the creation of the World Trade Organization (WTO) in 1995, which, counting 164 members, almost covers trade relations of the entire world. ${ }^{4}$ However, this almost universal membership makes amendments of the agreements difficult, but these might be necessary to keep the legal framework updated to the changing needs in the globalized and digitalized world. Despite the numerous demands to reform the WTO, the organization has not undergone any considerable changes since it was created in $1995 .{ }^{5}$ As a consequence, today one may observe that a number of its members engage with increasing commitment in the conclusion of trade and investment agreements. Several of them involve the European Union as a party, for example, the recent trade and association agreements (with Georgia, Moldova and the Ukraine), trade and investment agreements with Singapore and Vietnam and "Mega-Regionals" such as TTIP or CETA. Apart from the aim to foster trade relations, most of these recent trade and investment agreements have a trait in common - they claim to promote the rule of law by establishing a legal framework of binding substantive rules, which are secured by a dispute settlement mechanism.

Apart from the substantial interest of the relevant actors to further liberalize trade and to integrate further aspects that reflect their specific trade interests - the proponents highlight the overall benefits of the proposed agreements, which would bring a new "gold standard" to the existing trade agreements. ${ }^{6}$ This aspect also concerns the ambition to incorporate trade-related areas in these agreements that go beyond the WTO agreements. Moreover, with a view to the high degree of juridification of these agreements that comprise detailed rules on dispute settlement, the proponents claim that the new agreements will have a positive impact on the global rule of law, given that these standards would be adopted also by states, whose systems show deficits in this regard. Critics, however, suspect the opposite effect for national states and claim that these agreements would erode constitutional values, such as the rule of law and democracy. Subsequently, they regard, for instance, the proposed TTIP as an "Assault on Democracy and the Rule of Law".

4 According to John Jackson, some $90 \%$ of international law relates to international economic law, Jackson J. Global economics and international economic law, JIEL 1998, pp. 1-28 at 8.

5 Extensively on the history of the WTO see:

Van Grasstek, C. (2013). The History and the Future of the WTO, Geneva: WTO 2013. Available at https://www.wto.org/english/res_e/publications_e/historyandfuturewto_e.htm [last viewed 12.09.2016].

6 Robinson P. M., Dybvad K., Bäckström U. Financial Times 10 March 2014, The 'I' in TTIP will create a global gold standard. 2014. Available at http://www.ft.com/cms/s/0/be2a91c8-a5ff-11e3b9ed-00144feab7de.html\#axzz3eixUgOgV [last viewed September 12, 2016].

7 See above fn 1: Pinzler P. In: Die Zeit, “TTIP ist ein Angriff auf Demokratie und Rechtsstaat”, 15. May 2014. Available at http://www.zeit.de/wirtschaft/2014-05/interview-staeck [last viewed 12.09.2016], also Bode, T. (2015). TTIP, die Freihandelslüge, München: DVA. 
The contradicting assessments raise the questions, what is to be understood under the term "rule of law" in this context and what are the main elements and effects associated with it. Apparently, given that governance differs considerably on the national and international levels, one needs to differentiate between these two. Accordingly, the paper identifies and introduces the tools of international trade and investment agreements that aim at enhancing the rule of law. Subsequently, the paper examines the mechanism through which trade agreements may contribute to enhancing the rule of law in the contracting states. Finally, it will discuss the aspect, in how far the elements securing the rule of law correspond to the expectations to this principle, highlighting the potential conflict with other values, particularly with democratic decisions taken on a national level.

\section{Trade and investment agreements and the rule of law}

The attention that the media currently dedicates to trade and investment agreements may insinuate that they are a relatively new phenomenon. However, friendship and trade agreements have a long history and in their very beginnings go back to the $13^{\text {th }}$ century, when it comes to the agreements under the Hanseatic League (though the concept considerably differs with respect to the actors and the governing principles) or Trade and investment agreements concluded in the $17^{\text {th }}$ century. ${ }^{8}$ The concept of today's trade and investment agreements, however, differs from the most of these earlier agreements regarding their principal objective, as their main aim is to liberalize trade. By following this objective, they aim at generating welfare gains through trade, principally relying on Ricardo's concept of the comparative advantage. ${ }^{9}$ The concepts, accordingly, require their contracting parties to abstain from protective measures in the respective fields that form subject of the trade agreement. This trend basically started on two levels, firstly, globally, with the intent to create an International Trade Organization (ITO) that finally led to the signing of the General Agreement on Trade in Tariffs (GATT) in 1947 and secondly, regional trade agreements. Among the latter, the creation of the European Communities, notably the European Economic Community (EEC) are the best known. The initiation of these economic integration processes is no coincidence, but has to be seen in a historic context. Following the catastrophes of two world wars that at least partially were caused by international economic crises, international conferences strove to remedy the deficits by creating respective international organizations. The existence of trade agreements and respective international organizations thus manifests the widespread belief that trade agreements reduce international tensions and thus are beneficial for enhancing peace.

8 Tietje Chr. Die Beilegung internationalere Investitionsstreitigkeiten, In: Marauhn, Streitbeilegung, 47.

9 See, for instance, the WTO, Understanding the WTO: Basics, The case for open trade. Available at https://www.wto.org/english/thewto_e/whatis_e/tif_e/fact3_e.htm [last viewed September 12, 2016]. 
A few years later, in 1959, Germany and Pakistan signed the first modern bilateral investment treaty (BIT) aiming at the protection of private investments in the host states jurisdiction. Again, this type has historic forerunners, the concept, however, is a considerable modification and modernization of these frameworks and led to a new era of international protection of individual property rights. ${ }^{10}$ Slightly differing from trade agreements, the underlying concept of BITs aims at facilitating international investments, mostly capital streams/movements and establishments (notably, FDI). ${ }^{11}$ In order to achieve this aim, they strive at securing investments in foreign jurisdictions on an international level and under the regime of BITs, thus reducing risks, making investments more secure and predictable for investors. For the host state they seem to imply the prospect that they are supposed to bring the chance to foster development by incoming capital, technology and know-how.

The numbers of approx. 635 RTAs notified to the GATT/WTO ${ }^{12}$ and almost 3.000 BITs concluded worldwide ${ }^{13}$ suggest that both levels/types of economic agreements have been successful techniques for achieving the relevant aim. Trade and investment, however, frequently cannot be strictly separated from each other, given a close relation, causality, and interconnection leading to overlaps. Already the EEC thus incorporated protection mechanisms of both trade and investment via the four economic freedoms. Increasingly, trade agreements have become more comprehensive, and, today, as trade and investment agreements besides protecting trade also tend to incorporate investment chapters that aim at creating investment regimes, respectively, may even aim at replacing previously existing BITs. ${ }^{14}$

While the primary raison d'être of these agreements obviously is liberalizing trade, they simultaneously follow different, not necessarily subordinated objectives. In this regard the history of the European Communities (ECs) is rather instructive, particularly, the European Economic Community (EEC) -all three of which were vehicles for fostering peace in Europe. ${ }^{15}$ By aiming at increased integration in Europe, these ideas were accompanied and secured by an innovative and dynamic legal regime. Eventually, it was precisely this legal framework, which achieved European integration by law but, as illustrated by today's, Art. 2 TEU, made the EU an organization, which is far more than a mere trade agreement.

10 Tietje Chr. Die Beilegung internationalere Investitionsstreitigkeiten, in: Marahn, Streitbeilegung, 47 or Chester Brown, International Investment Agreements - History, Approaches, Schools. In: Bungenberg M., Griebel J., Hobe S. and Reinisch A. (eds.). International Investment Law, Nomos, 2015, pp. 153-185.

11 Schewe C. Die Beteiligung nichtstaatlicher Akteure in Streitschlichtungssystemen des internationalen Handels, Nomos 2008, pp. 96-104.

12 Available at https://www.wto.org/english/tratop_e/region_e/region_e.htm [last viewed September 12, 2016].

13 According to UNCTAD, there are currently 2953 BITs, of which 2322 are in force plus 362 Treaties with Investment Provisions of which 294 are in force. Available at http://investmentpolicyhub. unctad.org/IIA [last viewed September 12, 2016].

14 Schewe C. Die Beteiligung nichtstaatlicher Akteure in Streitschlichtungssystemen des internationalen Handels, Nomos 2008, pp. 52-54, overview at: 240.

15 Schuman R. The declaration of $9^{\text {th }}$ May 1950. Available at http://www.robert-schuman.eu/en/ declaration-of-9-may-1950 [last viewed September 12, 2016]. 
Even though having a much stronger focus on the economic orientation of the agreements, the latest generation of trade and investment agreements also advertises the non-economic aims of the agreements. ${ }^{16}$ The objective to set new global standards and enhance the rule of law in the partner country ${ }^{17}$ opens the question, what trade agreements understand under "the rule of law" and how trade and investment agreements may effectively contribute to fostering it in their contracting parties' jurisdictions. Furthermore, in the affirmative case that trade and investment agreements aim at enhancing the rule of law, it raises the question, if this may conflict with the rule of law on a national level, the Rechtsstaat.

\section{What is the rule of law/Rechtsstaat?}

While the national state used to be the traditional space for governance, the efficiency of this concept is being increasingly questioned. With regard to global challenges, for instance, environmental questions, climate change, terrorism or managing the cyber space, certain matters need to be addressed by the international community or at least by several states acting jointly. Accordingly, international organizations and agreements concluded for dealing with these issues increasingly bind states and thus bring repercussions for them and their national law. Both organizational levels the national and international - may be committed to the rule of law, however, they may overlap and stand in conflict with each other. This raises the question as to how far the concepts differ and if so, how to deal with potential conflicts.

\subsection{The Rechtsstaat-rule of law on the national level?}

Rather than using the term "rule of law", most European States, having civil law traditions, adhere to the concept of the Rechtsstaat ("state of law"). ${ }^{18}$ The wording of the notion insinuates its dominant function, to govern a state on the grounds of law and simultaneously, to make it subject to law. Indeed, Rechtsstaatlichkeit is one of the constitutional principles, which establishes that the state sets up und guarantees its legal order (Rechtsstaat in a formal sense [narrow understanding]). In general, it stipulates that all activities of public institutions are bound to the law. ${ }^{19}$ Some elements of this principle are explicitly mentioned, while other elements implied have developed over time. The most important elements are the separation of power and the guarantee of personal fundamental rights, but the principle also implies

16 Read the preamble of CETA, recitals 4-12. For instance recital 5: "Recognising the importance of international security, democracy, human rights and the rule of law for the development of international trade and economic cooperation;"

17 International Trade Administration (US Department of Commerce), Free Trade Agreements http://www.trade.gov/fta/ "Trade Agreements reduce barriers to U.S. exports, and protect U.S. interests and enhance the rule of law in the FTA partner country" [last viewed September 12, 2016].

18 Rechtsstaatlichkeit, l'État de droit, estado de derecho, stato di diritto, estado de dereito, tiesiska valsts (princips), õigusriik, dutch: rechtsstaat; Danish: retsstaten, Swedish: rättsstaten. This presentation is limited to the German concept of the Grundgesetz.

19 Art. 20 (3) GG. 
that the legislator is bound to the constitutional order and that the legislative and executive are both bound by laws and law (more precisely: Gesetz und Recht / likums un tiesibas). The principle, furthermore, comprises that the executive, in particular, administration must act legally, i.e. on the grounds of law (according to the principle of the legality of administration), and according to the principle of statutory reservation. The latter provides that the executive may only encroach on personal rights on the grounds of an existing legal basis. But also the acts providing an advantage for the addressee may require a legal basis, given that the advantage may simultaneously imply a disadvantage for somebody else. This is, for instance, the case regarding subsidies. Moreover, for the cases concerning "essential decisions" of the executive and encroaching on "principal normative matters, particularly in the exercise of fundamental rights", the Bundesverfassungsgericht requires for the legal basis to be enacted by parliament.

Notwithstanding conformity with these formal elements, it is conceivable that the substance of laws is unjust, i.e. that the application of laws does not correspond to what would be expected as justice. Accordingly, also in response to the experiences with the Third Reich, the narrow concept of the formal Rechtsstaatlichkeit was complemented by a wider understanding. This broader concept, substantive Rechtsstaatlichkeit (materielle Rechtsstaatlichkeit) aims at directing and limiting the potential content of public activities.

Additional aspects covered by the term Rechtsstaatlichkeit are the principle of proportionality, legal certainty and the protection of legitimate expectations but also the guarantee for the existence of effective legal protection. Finally, it comprises certain constitutional principles in criminal law and establishes the principle of state liability for illegal acts of public authorities.

Notwithstanding the use of similar terms in different states, the concepts may slightly differ as they are marked by the constitutional traditions and by the history of the respective states. ${ }^{20}$

\subsection{The rule of law in international trade and investment agreements}

Trade and investment agreements aim at liberalizing economic relations by removing barriers to trade and investments. ${ }^{21}$ Generally, the commercial actors have a strong interest in predictability and stability of the relevant legal framework. Accordingly, they have an interest that the relevant law is respected and, that the legal regimes provide efficient mechanisms for securing the agreements. Today, most of the trade

20 Pedro Cruz Villalón in von Bogdandy/ Cruz Villalón/Huber (Hg), Handbuch des Ius Publicum Europaeum, Band I, 2007, \$ 13, Para. 58.

21 The EU differs with regard to trade agreements (and also to its predecessor, the EEC), given that the fields governed are not limited to economic aspects but cover broad range of issues. It is also with regard to the potential effects of an increasingly powerful supranational Community, that made it necessary to integrate provisions that protect individuals from the EU's activities. Today, these are to be found among the values listed in Art. 2 TEU, which explicitly expresses that it is committed to the protection of fundamental rights. Accordingly, its Art. 2 TEU, which, inter alia, stipulates that the Union is based on the rule of law follows a comparable concept and content to that explained above. 
and investment agreements are binding to the contracting parties and have provisions on dispute settlement, which differ for trade ${ }^{22}$ and for investment ${ }^{23}$ disputes. Similar to the WTO, where decisions of the dispute settlement panels/the Appellate Body can be retaliated, ${ }^{24}$ the decisions of dispute settlement bodies of trade agreements also have - to a certain extent - become enforceable. ${ }^{25}$ The investment rules trade and investment agreements, however, go beyond this mechanism, applying the principle of BITs according to which awards of arbitrational tribunals are enforceable. ${ }^{26}$ Conformity of the contracting parties with these rules is in so far vital for the agreements, as failure might directly translate in distrust of the economic actors and potentially lead to the diversion of trade and investment streams.

Given that international trade agreements do not govern the relations in one state but within economic regions and taking into account that they are frequently drafted in the English language, when referring to the concept, trade and investment agreements rather use the term "rule of law".

\section{The impact of trade and investment agreements on national legal systems and the Rechtsstaat}

By ratifying the binding international trade and investment agreements, states commit themselves to adhering to the negotiated rules. Usually, these international agreements oblige contracting parties to liberalise markets and to remove barriers to trade. The effect of trade and investment agreements, however, differs according to the commitments made and with respect to the respective national legal order and the rank it attributes to international law. While the provisions of BITs are per se directly applicable for investors, this is not the case for trade agreements, which would require additional criteria and thus are, in practice, mediated by the home state of traders. ${ }^{28}$

\subsection{The impact on the rule of law}

With regard to the programmatic aim of trade and investment agreements, to enhance predictability and the rule of law, it appears contradictory that some consider TTIP as an "assault on the rule of law". As has been illustrated above, trade and investment agreements govern specific economic relations between states and try to achieve the rule of [the agreements'] law in these respective areas. The interest of foreign traders/investors in stable and predictable legal conditions frequently corresponds

22 See, for instance, CETA, Chapter 29.

23 See, for instance, CETA, Chapter 8.

24 So-called retaliation, see Article 22.2 DSU

25 See, for instance, CETA Art. 29.14.

26 See, for instance, CETA Art. 8.41

27 See, for instance, the preamble of CETA, recital 5.

${ }^{28}$ CETA and TTIP explicitly exclude direct applicability of trade provisions. 
with the relevant actors on a national level, however, it may also oppose other national interests. ${ }^{29}$ While trade and investment agreements are limited to the economic areas covered, this focus necessarily excludes other areas, which are, nevertheless, important for states and potentially also for the international community. Illustrative examples of the recent past are the conflicts with environmental or health concerns in the disputes on fracking, GMOs, nuclear energy etc. Evidently, these different interests need to be balanced, which, in practice, is a delicate process that often implies an assessment of interdisciplinary and international matters. Notwithstanding that, the mere fact that the agreements explicitly focus on trade and investment and not on health or the environment, may evoke the suspicion that agreements and their judiciary tend to be biased in favour of free trade.

This situation may thus stand in opposition to the legal assessment of national courts and national law. These have a much broader scope for their legal assessment ${ }^{30}$ and, consequently, may value the health of citizens higher than potential profits and losses of companies, and which stands in line with the respective national law. In extreme cases, judicators on both levels would have to pronounce their decisions according to the governing law, without having any room for discretion to resolving the conflict which raises the question as to which law prevails. With respect to the interest of effectively governing international challenges and the usually higher number of persons affected, at the first glance, there may be a tendency to assume that the interest of the international community should prevail over certain particular regional or national interests. This utilitarian approach has become visible in the EU, where EU law has primacy over national law and where decisions have been based on the community interest, which prevails over individual fundamental rights. ${ }^{31}$ While EU member states are even legally prevented from applying national legislation which infringes with EU law, ${ }^{32}$ this is different under international investment law. In case of infringements of investment law, ISDS awards generally do not oblige states to alter their legislation but (only) aim at compensating the investors that have suffered losses because a state did not act in conformity with the governing rules. Formally, there is no impact on national law, as it remains intact. Factually, however, economic constraints will urge the state to alter the relevant legislation in order to prevent similar future claims and the potential risk to pay high damages. Accordingly, it is indeed plausible that the public may conceive it as an "assault on the rule of law and democracy", if a state is factually forced to amend legislation ${ }^{33}$

29 Notwithstanding, it needs to be clarified that some actors may also have an interest in protectionist measures if they want to avoid competition. An illustrative example is the WTO case USA-Japan, which reflects the interests of the companies Kodak and Fuji, adopted by DSB on 22 April 1998, WT/DS 44/R.

30 The fact that all legal areas form as system is also considered as the "unity of the legal order" (Einheit der Rechtsordnung).

31 ECJ, (1970) Case No. 11/70 Internationale Handelsgesellschaft, para. 25.

32 Primacy of application (Anwendungsvorrang); in practice, however, they will amend respective legal acts. Similarly, recommendations of the disputes settlement panels/AB may oblige WTO members to bring the national in conformity with WTO.

33 Or to abstain from enacting respective legal acts for health protection, etc; an effect, which is called "regulatory chill". 
that is based on the democratic mandate. Even though the wording "assault" - which implies the intention of the drafters - insofar goes too far in its criticism, still, in essence, there may arise conflicts between the rule of law of trade and investment agreements and the national Rechtsstaaten, which cannot be easily solved.

\subsection{Reconciling the conflict}

With regard to the growing criticism of trade and investment agreements, the negotiators of the TIIP/CETA are under pressure to find solutions for the detected flaws. For the abovementioned collision between trade/investment and conflicting values and interests, this means, that, in order to adjudicate disputes, panellists and arbitrators need to have recourse to provisions securing legitimate concerns of the states. The most operational solution seems to be the insertion of "public policy" derogations into the agreements texts, which may justify the states' acts. While this solution protects the capacity of states to regulate, however, it may weaken the 'rule of law of trade and investment agreements' (following a narrow understanding) and thus undermine the confidence of traders and investors. Simultaneously, the mere insertion of a respective clause does not entirely eliminate the risk for states that international judiciary assesses public policy differently than the states' authorities. Notwithstanding these general concerns, courts and tribunals have illustrated that escape-clauses and derogations may be handled in practical ways. Despite frequent criticism, the case law of the ECJ/CJEU, also the decisions of the WTO settlement bodies may serve as examples, given their relevant long practice and experience. Similarly, the current debate contributed to modernizing and improving the conventional system of international investment law. Frequently, suggestions for amending the system refer to experiences in the field of trade, since certain instruments and techniques may be transferable (appeal instance, enhanced transparency, etc). ${ }^{34}$ The CETA, as the most recent example illustrates that the arguments of critics may be adopted in negotiations and finally become integrated in the texts of agreements. With regard to the persisting critique of the CETA, it remains to be seen, if it will be ratified and, if so, whether and how the provisions will be used according to the expectations.

\section{Conclusion}

In the $21^{\text {st }}$ century, trade and investment agreements have become an important instrument in the governance of international relations and for (partially) managing globalisation. Given that these trade rules quantitatively form a significant part of international rules, which are frequently subject to dispute settlement, they also

34 Gaukrodger D. and Gordon K. Investor-State Dispute Settlement: A Scoping Paper for the Investment Policy Community, OECD Working Papers on International Investment, 2012/03, OECD Publishing. Available at http://www.oecd.org/investment/investment-policy/WP-2012_3. pdf [last viewed September 12, 2016]. 
contribute to the evolution of international law. ${ }^{35}$ With regard to these two aspects, some consider that binding trade and investment agreements may contribute to the rule of law, not only within the agreement, but also beyond, in the contracting parties. Others, however, state, that the rules represent particularly the commercial interest of some economic actors and thus rather undermine the rule of law in states, as the rules are capable to overrule the conflicting rules of domestic law. Indeed, these concerns indicate that trade and investment agreements cover only one sector and thereby are susceptible to ignoring other values and interests, which domestic law would take into consideration. As long as the international law remains fragmented and does not bring together the different fields, one needs to imply escape clauses for states to protect these aspects of overriding interest. Admittedly, this may affect the effectiveness of the trade and investment agreements, but, nevertheless, it is necessary to reconcile the conflicting interests. It is the challenge for the negotiators of the agreements to find the right wording for the agreements' provisions, but also for the adjudication, to interpret these norms in a way that reflects the spirit of the agreement, but also corresponds to the interests of the parties and their national law and values.

\section{BIBLIOGRAPHY}

\section{Literature}

1. Bode T. TTIP, die Freihandelslüge, München: DVA, 2015.

2. Pedro Cruz Villalón in von Bogdandy/ Cruz Villalón/Huber (Hg), Handbuch des Ius Publicum Europaeum, Band I, 2007.

3. Gaukrodger D., and Gordon K. Investor-State Dispute Settlement: A Scoping Paper for the Investment Policy Community, OECD Working Papers on International Investment, 2012/03, OECD Publishing. Available at http://www.oecd.org/investment/investmentpolicy/WP-2012_3.pdf [last viewed September 12, 2016].

4. Jackson J. Global economics and international economic law, JIEL 1998, 1-28 at 8.

5. Mc Rae D., The contribution of International Trade law to the Development of International Law, Recuil des cours, Vol. 1, 1996, pp. 99-237.

6. Schewe C. Die Beteiligung nichtstaatlicher Akteure in Streitschlichtungssystemen des internationalen Handels, Nomos, 2008.

7. Van Grasstek C. The History and the Future of the WTO, Geneva: WTO, 2013. Available at https://www.wto.org/english/res_e/publications_e/historyandfuturewto_e.htm [last viewed September 12, 2016].

\section{Legislative acts}

1. Consolidated versions of the Treaty on European Union (TEU) and the Treaty on the Functioning of the European Union (TFEU) - Consolidated version of the Treaty on the Functioning of the European Union - Protocols - Annexes - Declarations annexed to

35 See already Mc Rae D. The Contribution of International Trade Law to the Development of International Law, Recuil des cours, Vol. 1, 1996, pp. 99-237. 
the Final Act of the Intergovernmental Conference, which adopted the Treaty of Lisbon, signed on 13 December 2007, Official Journal C 326, 26/10/2012, pp. 0001-0390.

\section{Legal practice}

1. ECJ, Case No. 11/70 Internationale Handelsgesellschaft, 1970. Available at http://curia.europa. eu/ [last viewed September 12, 2016].

2. WTO, Appellate Body, Kodak and Fuji, adopted by DSB on 22 April 1998, WT/DS 44/R.

\section{Other sources}

1. Pinzler P. Freihandelsabkommen: “TTIP ist ein Angriff auf Demokratie und Rechtsstaat", Interview with Klaus Staeck, Die Zeit, 14 May 2014. Available at http://www.zeit.de/ wirtschaft/2014-05/interview-staeck [last viewed September 12, 2016].

2. Pinzler P. Uchatius W. und Kohlenberg K. Schattenjustiz: Im Namen des Geldes, DIE ZEIT Nr. 10/2014, 27 Februar 2014. Available at http://www.zeit.de/2014/10/investitionsschutzschiedsgericht-icsid-schattenjustiz [last viewed September 12, 2016].

3. De Gucht K. European Commission TTIP and the Investment Dimension: What is the State of Play? 24 June 2014, Press release. Available at http://europa.eu/rapid/press-release SPEECH-14-494_en.htm [last viewed September 12, 2016].

4. Council of the European Union, Directives for the negotiation on the Transatlantic Trade and Investment Partnership between the European Union and the United States of America, document 11103/13 DCL 1, 17 June 2013. Available at http://data.consilium.europa.eu/ $\mathrm{doc} /$ document/ST-11103-2013-DCL-1/en/pdf [last viewed September 12, 2016].

5. European Commission indicating the CETA as recent trade agreement on the TTIPwebpage. Available at http://trade.ec.europa.eu/doclib/press/index.cfm?id=1230 [last viewed September 12, 2016].

6. European Commission, European Commission Fires Starting Gun for EU-US Trade Talks, Press release, Brussels, 12 March 2013. Available at http://europa.eu/rapid/press-release_IP13-224en.htm [last viewed September 12, 2016].

7. Robinson P. M., Dybvad K., Bäckström U. Financial Times 10 March 2014, The 'I' in TTIP will create a global gold standard. Available at http://www.ft.com/cms/s/0/be2a91c8-a5ff11e3-b9ed-00144feab7de.html\#axzz3eixUgOgV [last viewed September 12, 2016].

8. Schuman R. The declaration of $9^{\text {th }}$ May 1950. Available at http://www.robert-schuman.eu/ en/declaration-of-9-may-1950 [last viewed September 12, 2016].

9. WTO, Understanding the WTO: Basics, The case for open trade. Available at https://www. wto.org/english/thewto_e/whatis_e/tif_e/fact3_e.htm [last viewed September 12, 2016]. 
Kristine Dupate, Dr. iur., LL.M.

University of Latvia, Latvia

\title{
THE IMPACT OF THE INTERNATIONAL LAW ON THE CONCEPTS OF 'MARRIAGE' AND 'FAMILY' UNDER THE CONSTITUTION OF THE REPUBLIC OF LATVIA AND OBLIGATION OF THEIR SUPPORT AND PROTECTION
}

\begin{abstract}
Summary
No international agreement provides an explicit competence in the field of the family law, however, through the competences in other fields of law the international law has an implicit competence to define such concepts as 'marriage' and 'family'. Latvian national law is very conservative with regard to the forms of family, therefore international agreements with regard to some aspects introduce more modern understanding. However, it leads to fragmentation and certain inconsistencies. The article provides the overview on interaction between Latvian and international law relating the concept of 'family' and gives the analysis on the current state of national law and international legal obligations and their possible future interaction and development.
\end{abstract}

Keywords: the concepts, marriage, family, international law, the Constitution, national law, different content of the concepts, formal and functional definition, the needs of the society.

\section{Introduction}

Although no international agreement provides an explicit competence in the field of the family law, where the central concepts are 'marriage' and 'family', nevertheless, through the competences in other fields of law the international law has an implicit competence to define such concepts. Latvian national legal regulation regarding the concepts of 'marriage' and 'family' is very conservative and has not been developed considerably for decades, while international legal instruments recently have rapidly developed these concepts. As a result, different concepts operate in the fields of law under national competences and in the fields covered by international agreements. This situation leads to the fragmentation and inconsistent understanding of the concepts in question. The aim of this article is to describe the situation and provide an analysis on the current state of national and international legal regulation and their interaction in the light of the rapidly changing forms of families ${ }^{1}$ with a particular stress upon legal recognition and protection of the partnership between adults. The analysis provided regarding international law is restricted to the European Convention for the Protection of Human Rights and Fundamental

Roagna I. Protecting the right to respect for private and family life under the European Convention on Human Rights, Council of Europe human rights handbooks, Strasbourg, 2012, p. 27. 
Freedoms (further - ECHR) and the law of the European Union (hereinafter the EU law) as the main regional European international law instruments. This article will not analyse the concept of marriage and family from the perspective of private international law.

\section{The scope of application of national and international law}

Chapter 8 of the Constitution of the Republic of Latvia ${ }^{2}$ sets down the fundamental rights. The Constitution includes all three generations of the human rights - civil and political, economic, social and cultural rights as well as some third generation human rights. With regard to the concepts of 'marriage' and 'family', there are two relevant articles in the Constitution - Article 96 provides for the inviolability of private life, while Article 110 stipulates the state's obligation to protect and support a marriage and family. However, Article 89 of the Constitution obliges to provide and protect the human rights in accordance with the binding international agreements, therefore Latvia is under the obligation to comply with the binding international standards and has to interpret the Constitution and national law accordingly.

Under Article 1 of the ECHR, the states parties are under an obligation to ensure the human rights provided therein to everyone under their jurisdiction. Speaking about the concepts of 'marriage' and 'family', there are two main provisions Article 12 providing for the right to marry and Article 8 requiring the protection of family life. Such provisions may also interplay with other articles of the ECHR. ${ }^{3}$ The European Court of Human Rights (hereinafter - ECtHR) who is in charge of the 'observance of the engagements undertaken' by the states parties or, in other words, who provides the interpretation of the ECHR, has considerably extended the protective scope of the rights provided therein, including Article $8 .^{4} \mathrm{It}$, undoubtedly, has an impact on the national legal regulation and understanding of the concepts, especially, 'family' or 'family life'.

The EU (initially, European Economic Community) was founded with an aim to establish a common market, thus the competences of the EU are formally restricted to economic integration. ${ }^{5}$ However, even economic integration involves issues related to the concepts of family, for example, with regard to the free movement of the EU citizens. Therefore, the EU law to a certain extent and in the fields of its competence regulates the concepts in question. In addition, although only within the scope of the EU competence, the concepts of 'marriage' and 'family' and obligation to ensure

Latvijas Republikas Satversme, Official Gazette (Latvijas Vēstnesis) No. 43, 1 July 1993.

3 Roagna I. Protecting the right to respect for private and family life under the European Convention on Human Rights, Council of Europe human rights handbooks, Strasbourg, 2012, p. 24.

4 Roagna I. Protecting the right to respect for private and family life under the European Convention on Human Rights, Council of Europe human rights handbooks, Strasbourg, 2012, p. 7.

5 Craig P., Burca G. EU Law. Text, cases and materials, $5^{\text {th }}$ edition, Oxford University Press, Oxford, p. 6. 
and protect the right to marry and family life is also provided by the Charter of Fundamental Rights of the European Union (further - CFREU). ${ }^{6}$

\section{The definitions}

Article 110 of the Constitution itself provides only a definition of marriage, which could be only a union between man and woman. It does not specify explicitly anything with regard to the substance of the concept of 'family', therefore, it is a matter of the interpretation. So far, the Constitutional Court of Latvia, ${ }^{7}$ by referring to the ECtHR, has admitted that the concept of 'family' applies not only to the unions which are based on the marriage but also to the factual unions and that in providing protection and support to the families the social and biological reality prevails over legal presumption. ${ }^{8}$ However, so far the Constitutional court has made such conclusion only in cases relating parent and children relationship. ${ }^{9}$

Regarding adult partnership, Latvian national law recognizes only marriage and only between two persons of the opposite sex. ${ }^{10}$ The concept of family under national law is also defined very restrictively - Article 214 of the Civil Law provides that family in the narrow sense is composed of married spouses and their children, while they cohabit in the single household. Consequently, the partnership between adults must be based on marriage and only their common children are considered to be a part of the family under family law.

It follows that, in principle, Latvian national law defines the concept of family in a formal way, i.e., for the purposes of the recognition of family, legal presumption prevails over social reality.

The concept of family and also, to the certain extent, the concept of marriage is much broader under ECHR. Firstly, the ECtHR has held that 'family life' entails not only unions based on marriage but it "may encompass other de facto relationships". ${ }^{11}$ The existence of the 'family life' is dependent upon the real existence in practice of close personal ties. In order to establish if such close personal ties exist, the following considerations may be relevant, for example, whether a couple lives together, the length of the relationship, the level of commitment by having common children

6 Official Journal C 202/2, 7 June 2016.

7 The Constitutional Court Law (Satversmes tiesas likums), Official Gazette (Latvijas Vēstnesis) No. 103, 14 June 1996.

8 The decision in Case No. 2004-02-0106, Official Gazette No. 161, 12 October 2014, paragraph 14, by referring to the decisions of the ECtHR in Cases: Kroon and others v. the Netherlands (application No. 18535/91), paragraph 40 (27 October 1994), Marckx v. Belgium (application No. 6833/74), 13 June 1979; X, Y and Z v. the United Kingdom (application No. 21830/93), 22 April 1997; Keegan v. Ireland (application No. 16969/90), 26 May 1994.

9 See also decisions of the Constitutiona Court in Cases No. 2015-10-0, Official Gazette No. 231, 25 November 2015 and No. 2015-22-01, Official Gazette No. 123, 29 June 2016.

10 Article 35 of the Civil Law (Civillikums), Official Gazette No. 22, 10 June 1993.

11 The ECtHR decision in Case: X, Y and Z v. the United Kingdom (application No. 21830/93), 22 April 1997. 
or by other means. ${ }^{12}$ Recently, however, the ECtHR has overruled the former condition - cohabitation requirement, by stressing that there can be no basis for drawing the distinction between the couples who live together and those, who for professional and social reasons - do not, "because the fact of not cohabiting does not deprive the couples of the stability which brings them within the scope of family life" ${ }^{13}$

Secondly, the recognition of the family life between two adult partners does not depend on their sex, in particular, as the ECtHR has stressed that taking into account growing European consensus it would be artificial 'to maintain the view that, in contrast to different sex couple, a same-sex couple cannot enjoy 'family life' for the purposes of ECHR. ${ }^{14}$ Thus, the protection of family life under the ECtHR is equally applicable to heterosexual and homosexual couples, which was also reapproved in following decisions. ${ }^{15}$

Thirdly, according to ECtHR, the relationships, which may be considered as falling within the notion of 'family life' are not restricted only to married or unmarried partners, their children, but also between children and their grandparents; between siblings; between an uncle or aunt and his/her nephew or nieces, between adoptive/ foster parents and children. ${ }^{16}$

Fourthly, the ECtHR, by admitting that currently it cannot be concluded that Article 12 of the ECHR imposes an obligation on the states to open marriage to the same-sex couples, nevertheless, it "would no longer consider that the right to marry enshrined in Article 12 must in all circumstances be limited to marriage between to persons of the opposite sex." ${ }^{17}$

It follows that, under the ECHR, the concept of family and, to a certain extent, also marriage is understood broadly, as the ECtHR is a living instrument, which has to be interpreted according to the current realities. ${ }^{18}$ Consequently, the concept of 'family' under the ECHR is defined by the functional rather than formal definition.

The EU law defines the concept of 'family' and 'marriage' within its competence.

12 The ECtHR decision in Case: X, Y and Z v. the United Kingdom (application No. 21830/93), 22 April 1997.

13 The ECtHR decision in Case: Pajič v. Croatia (application No. 68453/13), 23 February 2016, paragraph 65; see also decision in Case: Vallianatos and others v. Greece (application Nos. 29381/09, 32684/09), 7 November 2013, paragraph 73.

14 The ECtHR decision in Case: Schalk and Kopf v. Austria (application No. 30141/04), 24 June 2010, paragraphs 93-94.

15 For example see the ECtHR decisions in Cases: Vallianatos and others v. Greece (application Nos. 29381/09, 32684/09), 7 November 2013, paragraphs 78 and 81; Oliari and others v. Italy (application No. 18766/11,36030/11), 21 July 2015, paragraph 165.

16 Roagna I. Protecting the right to respect for private and family life under the European Convention on Human Rights, Council of Europe human rights handbooks, Strasbourg, 2012, p. 28.

17 The EctHR decision in Case: Schalk and Kopf v. Austria (application No. 30141/04), 24 June 2010, paragraph 61; see also Oliari and others v. Italy (application No. 18766/11, 36030/11), 21 July 2015, paragraph 191.

18 See, for example, the the ECHR decision in Case: Christine Goodwin v. The United Kingdom (application No. 28957/95), 22 July 2002, paragraphs 74-75. 
First of all, Article 7 the CFREU $^{19}$ provides for the right to respect of the family life, reflecting, to a great extent, Article 8 of the ECHR, while Article 9 provides for the right to marry and to found a family. The latter article intentionally 'skips' the reference to two persons of opposite sex who may marry in order to reflect the fact that in number of the EU Member States marriage is open to the same-sex couples. ${ }^{20}$ However, as it is known, the CFREU has a limited scope of application, i. e., according to Article 51, the rights and obligations provided there in are binding only to the EU institutions and to the EU Member States, as far as they act within the competence of the EU. In addition, it is for the Member States to define the concept of 'marriage' and the right to found the family.

However, there are secondary EU legal acts providing for particular rights and obligations. Taking into account the competence of the EU, ${ }^{21}$ the concept of 'family' and 'marriage' is defined in certain fields.

Directive 2004/38/EC 22 regulating free movement of the EU citizens and their family members recognizes as the family members very extensive cycle of persons. Article 2(2) explicitly recognizes as the family members not only married spouses, but also contracted or registered partners (usually married or registered in other EU Member State). In addition, since Directive 2004/38/EC contains no right to exception for a Member State refusing recognition of a married spouse, same-sex marriages have to be recognized for the purposes of the free movement of the EU citizens in all Member States. Further, Article 2(2)(b) provides the right to a Member State refuse recognition of registered partnership, if a Member State itself has no legal recognition of such unions in their national law. However, the application of such exception is doubtful on the account of following considerations. If a Member State according to its national law does not recognize same-sex unions, it is, nevertheless, under an obligation to recognize same-sex spouses for the purposes of migration within the EU, thus, it would be illogical to refuse recognition of registered partners. In addition, Article 3(2)(b) of Directive 2004/38/EC requires a recognition of a partner outside marriage or registered partnership as a family member, if EU citizen may prove durable relationship with this partner. It follows, that if a couple is officially registered, then such fact itself proves the compliance with the relevant provision. Consequently, Directive 2004/38/EC provides the combination of both formal and functional definition of a family member concerning the partnership between adults.

19 Official Journal C 202/2, 7 June 2016.

20 Explanations relating to Charter of Fundamental Rights of the European Union, Official Journal C 303/17, 14 December 2007.

21 Treaty on European Union and Treaty on the Functioning of the European Union, consolidated version, Official Journal of the European Union, C 202, 7 June 2016.

22 Directive 2004/38/EC of the European Parliament and of the Council of 29 April 2004 on the right of citizens of the Union and their family members to move and reside freely within the territory of the Member States amending Regulation (EEC) No 1612/68 and repealing Directives 64/221/EEC, 68/360/EEC, 72/194/EEC, 73/148/EEC, 75/34/EEC, 75/35/EEC, 90/364/EEC, 90/365/EEC and 93/96/EEC (Text with EEA relevance), OJ L 158, 30.4.2004, pp. 77-123. 
The obligation of the recognition and provision of the rights to the unions outside the marriage may emerge also in the context of Directive 2000/78/EC, ${ }^{23}$ prohibiting discrimination in employment on several grounds, including sexual orientation. According to the interpretation given by the Court of Justice of European Union (hereinafter - the CJEU), collective agreements, employment agreement or another source of the rights may not treat married and unmarried couples differently, where a national law does not allow same-sex marriages and with regard to the benefits concerning which unmarried couples could be considered as being in comparable situation with married couples. ${ }^{24}$ Such rights have to be provided, even if a national family law provides different legal regimes for unmarried (or registered) couples and married couples. As the CJEU has stressed, in order to establish discrimination "it is required not that the situations be identical, but only that they be comparable, on the other hand, the assessment of that comparability must be carried out not in a global and abstract manner, by in a specific and concrete manner in the light of the benefit concerned." ${ }^{25}$ In the particular case the dispute was about the collective agreement providing the right to additional days of leave in case of marriage, but not for the case of the celebration of the registration of the partnership. It follows that under the EU law the concept of family is defined rather functionally, in addition, it, depending on the aim and the purposes of the rights in question, may recognize the obligation to equal treatment between married and unmarried couples.

Overall, it follows that European regional international law requires, within its competence, an application of functional recognition of the (factual) family, as opposed to the Latvian law, which recognizes only formal (legally established) family.

\section{International law concepts in Latvian law}

As it follows from the previous section, Latvia has numerous international obligations under international agreements, thus, Latvian law reflects them.

In order to provide protection of private and family life under Article 8 of the ECHR, Article 12 of the Criminal Procedure $\mathrm{Law}^{26}$ provides that a person may require to remove from a criminal procedure file the data not only regarding legally recognized relatives (like spouse, children, brother etc.), but also regarding the persons, with whom he/she resides together in a common household. Also Article 110 of the Criminal Procedure Law and Article 303 of the Criminal Law ${ }^{27}$ reflect obligations

23 Council Directive 2000/78/EC of 27 November 2000 establishing a general framework for equal treatment in employment and occupation, OJ L 303, 2.12.2000, pp. 16-22.

24 The CJEU decision in Case No. C-267/12, Frédéric Hay v. Crédit agricole mutuel de CharenteMaritime et des Deux-Sèvres.

25 The CJEU decision in Case No. C-267/12, Frédéric Hay v. Crédit agricole mutuel de CharenteMaritime et des Deux-Sèvres, paragraph 33.

26 Kriminālprocesa likums, Official Gazette (Latvijas Vēstnesis) No. 74, 11 May 2005.

27 Kriminällikums, Official Gazette (Latvijas Vēstnesis) No. 199/200, 8 July 1998. 
deriving from Articles 6 and 8 of the ECHR, in particular, the right not to testify regarding close family members.

To be prepared for the ratification of the Council of Europe Convention on preventing and combating violence against women and domestic violence, amendments $\mathrm{s}^{28}$ to the Civil Procedure Law ${ }^{29}$ were adopted, implementing temporary protection measures. ${ }^{30}$ Article $250^{44}$ of the said law recognizes not only the right of the legally recognized family members to apply for the protection order, but grants this right also to the factual family members, including persons residing in the common household, persons expecting a common child and persons who do not reside in the common household, but who have had personal and intimate relationship.

The EU Directive 2004/38/EC is implemented by the Cabinet of Ministers Regulation No. $675,^{31}$ thus Latvian legal acts to the purposes of the migration of the EU citizens and their family members recognizes as the family members not only married spouses and registered partners, but also factual partners, who can prove at least two years long existence of the relationship (point 4.2.), or a couple has a common child (point 37.5).

It follows, that Latvian legal acts in certain fields, where it is required by the international agreements, recognizes factual existence of a family instead of only formal legally recognized family. It leads to the situation, where the different concepts of 'marriage' and 'family' exist and function under Latvian legal system, resulting in legal fragmentation.

\section{The current Latvian national legal regulation in the light of international obligations}

As a result of the fragmented legal regulation of the concepts of 'marriage' and 'family' in Latvian legal system described above, different legal issues may arise. Taking into account the limited space of the article, only two examples will be discussed - one, because it is topical and important for the general society, other, because it demonstrates the level of controversy, where fragmented legal regulation may lead.

Latvian legislator has to take into account the recent ECtHR decision in case Oliari, in which the obligation to establish legal regime for the recognition of same-sex

28 Explanatory note to the Parliament of the Republic of Latvia to the draft law No. 616/Lp11, available in Latvian at http://titania.saeima.lv/LIVS11/SaeimaLIVS11.nsf/0/7B8AEA1CC9C858 8EC2257B35002E8BCE?OpenDocument\#b ] last viewed August 20, 2016].

29 Civilprocesa likums, Official Gazette (Latvijas Vēstnesis) No. 326/330, 3 November 1998.

30 Amendments Official Gazette (Latvijas Vēstnesis) No. 41, 26 February 2014.

31 The procedure on the immigration and residence of the EU citizens and their family members in Latvia (Kārtìba, kādā Savienības pilsoṇi un vinu ǵimenes locekl̦i iecelo un uzturas Latvijas Republikā): The Regulations of the Cabinet of Ministers No. 675, Official Gazette (Latvijas Vēstnesis) No. 141, 7 September 2011. 
relationship was established towards Italy. ${ }^{32}$ The ECtHR repeated that obligation to protect family life under Article 8 of the ECHR "may involve the adoption of measures designed to secure respect for private or family life even in the sphere of the relations of individuals between themselves". 33 The recognition of the same-sex partnership is also supported by the fact of growing European consensus, as well as indications set by the highest judicial authorities and general society in Italy. ${ }^{34}$ In the light of these findings, the parallels regarding Latvian factual context may be drawn. The statistical data over the last decade demonstrates a stable increase in the number of children born outside the wedlock, thus indicating the necessity for the legal recognition and regulation of unregistered partnerships. This finding is supported not only by recent studies ${ }^{35}$ but also by the decisions of the Supreme Court of Latvia. ${ }^{36}$ It follows, that the factual context in Latvia indicates the necessity for the legal recognition of other forms of family under national law in addition to marriage.

Other example worth mentioning concerns immigration law, in particular, controversies or reverse discrimination against Latvian citizens in comparison to the citizens of other EU Member States. Such situation exists due to the existence of two separate immigration regimes. The EU law has a competence regarding migration of the EU citizens in the so-called 'cross-border' situations, i.e., in cases, when an EU citizen has used his/her free movement and residence rights in the EU and has moved from one Member State to another. The legal regulation of immigration without 'cross-border' element still falls within the competence of the Member States. Taking into account this, in Latvia as in other EU Member States, there is one legal regime for the immigration and residence of the EU citizens and their family members, but another for the family members of Latvian citizens, who remain in Latvia. The first is regulated by Directive 2004/38/EC, which is implemented by the Cabinet of Ministers Regulation No. $675,{ }^{37}$ while the second - by the Immigration Law. ${ }^{38}$ The problem lies in the fact that Directive 2004/38/EC recognizes much broader

32 The EctHR decision in Case: Oliari and others v. Italy (application No. 18766/11, 36030/11), 21 July 2015.

33 The EctHR decision in Case: Oliari and others v. Italy (application No. 18766/11, 36030/11), 21 July 2015, paragraph 159.

34 The EctHR decision in Case: Oliari and others v. Italy (application No. 18766/11, 36030/11), 21 July 2015, paragraphs $178-179$.

35 Projektu un kvalitātes vadība "Pētijums par laulïbu nereǵistrēšanas problemātiku" (The research on the problems with regard to the low number of marriages), 2015, available in Latvian at http:// www.pkc.gov.lv/images/Gala_zi\%C5\%86ojums_19012016.pdf [last viewed August 20, 2016]; see also Zvērinātu advokātu bïrojs Eversheds, Bitāns, "Pētijums par vīrieša un sievietes nereǵistrētu partneattiecību tiesisko regulējumu Eiropā un Latvijā" (The research on problems with regard to unregistered partnership between man and woman in Europe and Latvia), 2008, available in Latvian at www.tm.gov.lv [last viewed August 22, 2016].

36 The decision of 1 February 2012 of the Senate of the Supreme Court in Case No. SCC-4/2012; see also decision of 3 May 2016 in Case No. SKA-763/2016.

37 The procedure on the immigration and residence of the EU citizens and their family members in Latvia (Kärtība, kādā Savienības pilsoñi un vinu gimenes locekḷi iecelo un uzturas Latvijas Republikā): The Regulations of the Cabinet of Ministers No. 675, Official Gazette (Latvijas Vēstnesis) No. 141, 7 September 2011.

38 Imigrācijas likums: the law, Official Gazette (Latvijas Vēstnesis) No. 169, 20 November 2002. 
cycle of persons as the family members than the Immigration Law. It leads to the situation where, for example, Lithuanian citizen may legally reside in Latvia with his/her unmarried partner - a third country national, because Directive 2004/38/ EC is applicable, while Latvian citizen has no possibility to invite for the residence in Latvia his/her unmarried partner, because the Immigration Law recognizes only a married spouse as a family member. It leads to a reverse situation, namely, that, with regard to residence rights, the citizens of other EU Member States in Latvia enjoy far more favourable rights than the local Latvian citizens wishing to establish family life with a foreign citizen without moving away from Latvia.

This example highlights the deficiency of the fragmented and, thus, inconsistent legal regulation of the concept of family.

It follows that soon not only factual circumstances but also international agreements may impose on Latvian legislator an obligation to review and modernise and harmonize the concept of 'family' in Latvian legal system.

\section{Conclusions}

1. International law has a considerable impact on developing the understanding of the concept of 'family' and 'marriage' as provided by the Constitution of the Republic of Latvia, and this is reflected in the case law of the Constitutional Court, Supreme Court and Latvian law implementing obligations deriving from international agreements.

2. In the fields not covered by the international obligations, the concepts of 'marriage' and 'family' are interpreted narrowly, i.e., in the fields under national competence they are narrower than in the fields regulated by international law.

3. Therefore, different concepts of 'family' and 'marriage' operate in Latvian legal system depending on the field of the law, i.e., the legal regulation is fragmented.

4. The main difference between definition of the concept of 'family' under national and international law is that Latvian national law recognizes only legally established ties, i.e., the forms of families, which are legally recognized, thus, the concept of 'family' is regulated by formal definition. On the other hand, international law defines the concept of 'family' in functional way, i.e., it recognizes the priority of biological and social reality over legal presumption, thus providing protection for many more forms of family and, consequently, many more persons.

5. Since the different fields of law in real life interact with each other, the existence of different content of the same concepts may lead to legal uncertainty and collision of the rights.

6. The statistics and researches in Latvia demonstrate rapid multiplication of the family forms outside the marriage, thus, the legal distinction between legally recognized and factual families under national legislation could be hardly justified not only in the light of trends under international law but also in line with the developments in contemporary Latvian society. 
7. This situation indicates that soon the factual circumstances and also international agreements might impose on Latvian legislator an obligation to review, modernise and harmonize the concept of 'family' in Latvian legal system.

\section{BIBLIOGRAPHY}

\section{Literature}

1. Roagna I. Protecting the right to respect for private and family life under the European Convention on Human Rights, Council of Europe human rights handbooks, Strasbourg, 2012, p. 27.

2. Craig P., Burca G. EU Law. Text, cases and materials, $5^{\text {th }}$ edition, Oxford University Press, Oxford, p. 6.

\section{Legislative acts}

\section{International legal sources}

\section{The European Union}

1. Charter of Fundamental Rights of the European Union, Official Journal C 202/2, 7 June 2016.

2. Council Directive $2000 / 78 / \mathrm{EC}$ of 27 November 2000 establishing a general framework for equal treatment in employment and occupation, OJ L 303, 2.12.2000, pp. 16-22.

3. Directive 2004/38/EC of the European Parliament and of the Council of 29 April 2004 on the right of citizens of the Union and their family members to move and reside freely within the territory of the Member States amending Regulation (EEC) No 1612/68 and repealing Directives 64/221/EEC, 68/360/EEC, 72/194/EEC, 73/148/EEC, 75/34/EEC, 75/35/ EEC, 90/364/EEC, 90/365/EEC and 93/96/EEC (Text with EEA relevance), OJ L 158, 30.4.2004, pp. 77-123.

4. Treaty on European Union and Treaty on the Functioning of the European Union, consolidated version, Official Journal of the European Union, C 202, 7 June 2016.

\section{The Council of Europe}

5. Council of Europe Convention on preventing and combating violence against women and domestic violence.

6. European Convention for the Protection of Human Rights and Fundamental Freedoms.

\section{National legal sources}

7. Latvijas Republikas Satversme, Official Gazette (Latvijas Vēstnesis) No. 43, 1 July 1993.

8. The Constitutional Court Law (Satversmes tiesas likums), Official Gazette (Latvijas Vēstnesis) No. 103, 14 June 1996.

9. The Civil Law (Civillikums), Official Gazette No. 22, 10 June 1993.

10. The Civil Procedure Law (Civilprocesa likums), Official Gazette (Latvijas Vēstnesis) No. 326/330, 3 November 1998.

11. The Criminal Procedure Law (Kriminālprocesa likums), Official Gazette (Latvijas Vèstnesis) No. 74, 11 May 2005.

12. The Criminallaw (Kriminällikums), Official Gazette (Latvijas Vēstnesis) No. 199/200, 8July 1998.

13. Immigration Law (Imigrācijas likums), Official Gazette (Latvijas Vēstnesis) No. 169, 20 November 2002. 
14. The procedure on the immigration and residence of the EU citizens and their family members in Latvia (Kärtība, kādā Savienības pilsoñi un vinu gimenes locekļi iecelo un uzturas Latvijas Republikā): The Regulations of the Cabinet of Ministers No. 675, Official Gazette (Latvijas Vēstnesis) No. 141, 7 September 2011.

\section{Legal practice}

1. The CJEU decision in Case No. C-267/12, Frédéric Hay v Crédit agricole mutuel de Charente-Maritime et des Deux-Sèvres.

2. The ECtHR decision in Case: $X, Y$ and $Z$ v. the United Kingdom (application No. 21830/93), 22 April 1997.

3. The ECtHR decision in Case Pajič v. Croatia (application No. 68453/13), 23 February 2016.

4. The ECtHR decision in Case Vallianatos and others v. Greece (application Nos. 29381/09, 32684/09), 7 November 2013.

5. The ECtHR decision in Case: Schalk and Kopf v. Austria (application No. 30141/04), 24 June 2010.

6. The ECtHR decision in Case: Oliari and others v. Italy (application No. 18766/11, 36030/11), 21 July 2015.

7. The ECHR decision in Case: Christine Goodwin v. The United Kingdom (application No. 28957/95), 22 July 2002.

8. The decision of the Constitutional Court of Latvia in Case No. 2015-22-01, Official Gazette No. 123, 29 June 2016.

9. The decisions of the Constitutional Court of Latvia in Case No. 2015-10-0, Official Gazette No. 231, 25 November 2015.

10. The decision of the Constitutional Court of Latvia in Case No. 2004-02-0106, Official Gazette No. 161, 12 October 2014.

11. The decision of 1 February 2012 of the Senate of the Supreme Court of Latvia in Case No. SCC-4/2012.

12. The decision of 3 May 2016 of the Senate of the Supreme Court of Latvia in Case No. SKA-763/2016.

\section{Other sources}

1. Explanations relating to Charter of Fundamental Rights of the European Union, Official Journal C 303/17, 14 December 2007.

2. Explanatory note to the Parliament of the Republic of Latvia to the draft law No.616/Lp11, available in Latvian at http://titania.saeima.lv/LIVS11/SaeimaLIVS11.nsf/0/7B8AEA1CC9 C8588EC2257B35002E8BCE?OpenDocument\#b [last viewed August 20, 2016].

3. Projektu un kvalitātes vadība "Pētijums par laulību nereǵistrēšanas problemātiku" (The research on the problems with regard to the low number of marriages), 2015, available in Latvian at http:// www.pkc.gov.lv/images/Gala_zi\%C5\%86ojums_19012016.pdf [last viewed August 20, 2016].

4. Zvērinātu advokātu birojs Eversheds, Bitāns. "Pētījums par vīrieša un sievietes nereǵistrētu partnerattiecību tiesisko regulējumu Eiropā un Latvijā” (The research on problems with regard to unregistered partnership between man and woman in Europe and Latvia), 2008, available in Latvian at www.tm.gov.lv [last viewed August 22, 2016]. 
Emese Szilagyi, Dr. iur. cand.

Hungarian Academy of Sciences, Centre for Social Sciences, Hungary

\title{
THE VALUE OF POLITICAL EQUALITY - COMPARING THE PRACTICES OF THE ECTHR AND THE SUPREME COURT OF THE UNITED STATES
}

\begin{abstract}
Summary
Two of the most important values of modern democracies are political equality and freedom of expression. In the narrowest sense, political equality is realized by the "one person - one vote" rule, but the principle means more than this: it also involves, that everybody must have a real opportunity to influence the outcome of the elections, and everybody must have the possibility to seek supporters. At the same time, members of the public are entitled to receive information about the rival arguments in order to be able to form a well-founded decision at the end of the campaign. This definition proves, that freedom of expression is also inevitable in order to ensure a fair decision-making process. In the current paper I examine how the constitutional principle of political equality is presented in different European international law documents and in the practice of the European Court of Human Rights (ECtHR). I hypothesize that we can speak about a clearly recognizable European approach towards campaign-financing and I examine whether this approach really prefers political equality, as opposed to the constitutional attitude of the Unites States, where freedom of expression prevails, when the two constitutional values collide.

Therefore, in the first part of my paper I elaborate the idea of the "Europeanisation" of norms on campaign financing, and I turn to the problems raised by these European good practices. Namely, I look at the attitude towards the collision of political equality and freedom of political speech. Then I shortly describe the relevant constitutional practice of the United States, which is often used as a sharp contrast. Finally, I review the Animal Defenders International decision of the ECtHR, which is widely heralded as the European victory of political equality. As a conclusion, I find questionable, whether a blanket ban on corporate campaign-spending, which was at stake in this particular case, can in fact foster the realization of political equality.
\end{abstract}

Keywords: political equality, political speech, campaign financing, freedom of expression, Animal Defenders International.

\section{Preliminary remarks: A European regime of campaign financing?}

In the current paper I examine how the constitutional principle of political equality is presented in different European international law documents and in the practice of the ECtHR. This aim is achieved through focusing on the issues of campaign financing, especially on the problems of campaign spending and political advertising. At the first glance, it seems that a distinct European approach towards the problem exists and it prefers political equality, as opposed to the approach of the Unites States, where freedom of expression prevails, when the two constitutional values collide. But a close examination of the relevant case law shows that this statement 
is not sufficiently convincing. Due to the limits of the current paper, I use the recent Animal Defenders International v. The United Kingdom decision, as a core example.

I propose a hypothesis that we can speak about a clearly recognizable European approach towards campaign financing. In the last decades, a process of "Europeanisation" could be witnessed, and this process is characterized by a set of soft and hard law documents, issued by different institutions and bodies of the Council of Europe $^{1}$ and the European Union (EU). ${ }^{2}$ The idea of interpreting these very diverse documents together might seem strange, but it is not unusual in the relevant literature.

Behind this approach we can find the consideration that the "European legal regime" does not exclusively refer to the legal system of the EU; the process of Europeanisation does not stop at the borders of the EU, and it has a very strong effect on the neighbouring countries. Thus, the dynamics of Europeanisation exceeds the narrow interpretation of the European integration. ${ }^{3}$ In many cases, the institutions of the EU closely cooperate with the institutions of the Council of Europe, which encourages the spread of the ideals regarding campaign financing. ${ }^{4}$ This interpretation of Europeanisation is closely related to the phenomenon, which can be described as the regional impact of states with strong democratic traditions. ${ }^{5}$ For instance, the democratic transition of the countries in Central Europe was not fostered solely by the EU, but by other regional forms of cooperation, too. ${ }^{6}$ I agree with Timus, who states that, however, the EU has the leading role in the story of the European integration, when it comes to the principles of political campaigns, the influence of the Council of Europe, and especially that of the Venice Commission cannot be neglected. ${ }^{7}$

Such as: Recommendation $\operatorname{Rec}(2003) 4$ of the Committee of Ministers to member states on common rules against corruption in the funding of political parties and electoral campaigns; Code of Good Practice in the Field of Political Parties by European Commission for Democracy Through Law (Venice Commission) CDL-AD(2009)002; Guidelines and Report on the Financing of Political Parties by the Venice Commission CDL-INF (2001)8; Opinion of the Prohibition of Financial Contributions to Political Parties From Foreign Sources adopted by the Venice Commission CDL-AD (2006)014.

2 See especially: Regulation (EC) No. 2004/2003 of the European Parliament and of the Council of 4 November 2003; Regulation (EC) No. 1524/2007 of the European Parliament and of the Council of 18 December 2007 amending Regulation (EC) No. 2004/2003 on the regulations governing political parties at European level and the rules regarding their funding; Commission Delegated Regulation (EU, Euratom) 2015/2401 of 2 October 2015 on the content and functioning of the Register of European political parties and foundations.

3 Van Biezen I. Molenaar F. The Europeanisation of Party Politics? Competing Regulatory Paradigms at the Supranational Level. West European Politics, 2012, 16 April, No. 3. p. 634.

4 Timus N. The Impact of Democracy Promotion in Party Financing in the East European Neighbourhood. European Integration Online Papers, 2010, No. 3. p. 6.

5 Whitehead L. Democratic Regions, Ostracism and Pariahs. In: Whitehead L. (ed.). The International Dimensions of Democratization: Europe and the Americas. Oxford - New York: Oxford University Press, 1996, pp. 395-396.

6 Pridham G. The European Union, democratic conditionality and transnational party linkages: The case of Eastern Europe. In: Grugel J. (ed.). Democracy without Borders. Transnationalization and conditionality in new democracies. London and New York: Routledge, 1999, pp. 59-60.

7 Walecki shares this approach: Walecki M. The Europeanization of Political Parties: Influencing the Regulations on Political Finance. EUI Working Papers, 2007, No. 29. p. 2. 


\section{The European "good practices" of campaign financing}

Thus, the various guidelines and recommendations issued by the different bodies of the Council of Europe, and the legal regulations of the European Union together construct a distinct set of rules. This can be expanded with the principles established by the practice of the ECtHR. ${ }^{8}$ These documents and the respective case law of the Court together construct the European "good practices" of campaign finance. The aim of these good practices is to ensure and favour the realisation of political equality. The collision of the idea of political equality and freedom of expression can be detected in connection with two issues: the problems of private contributions and campaign spending. Considering the limits of this paper, I choose to focus only on these proposals.

The problem of private financing is a controversial and complex one. Many European documents urge establishing financial caps on private donations and explicit prohibition on contributions from industrial or commercial corporations. ${ }^{9}$ The argumentation behind these solutions is to prevent the distorting influence of well-endowed interests in the political competition. According to this argument, money representing vested interest, especially corporate money can monopolize the "marketplace of ideas" and undermine the fair competition among the rival political forces. John Rawls described this phenomenon as a distortion of democracy, "a kind of regulated rivalry between economic classes and interest groups in which the outcome should properly depend on the ability and willingness of each to use its financial resources and skills, admittedly very unequal, to make its desires felt." ${ }^{10}$ But, at the same time, financial contributions may help strengthening the relationship between a political party or candidate and its electorate and, in addition, contributions can be understood as a form of expressing political support, thus, a way of expressing a political opinion. Hence, the question arises, whether these limitations are acceptable forms of restricting freedom of expression.

On the other hand, the documents on campaign financing often argue for limiting campaign spending in order to curb the importance of money in politics. Spending limits may be able to weaken the influence of money in politics, and eliminate the financial inequality among the competing parties. But limiting campaign spending may restrict freedom of political speech. These spending limits may narrow the freedom of candidates and parties to express their political programmes, hence narrow the chance for the voters to gather more information. Moreover, limits on spending by third parties (restrictions on parallel campaigns) may also burden the freedom of expression of private individuals who wish to support a particular party or candidate.

8 Van Biezen I. Molenaar F. The Europeanisation of Party Politics? Competing Regulatory Paradigms at the Supranational Level. West European Politics, 2012, 16 April, No. 3. pp. 639-641.

9 Van Biezen I. Financing political parties and election campaigns - Guidelines. Strasbourg: Council of Europe Publishing, 2003, p. 30.

10 Rawls J. Political Liberalism, Expanded Edition. New York: Columbia University Press, 2005, p. 361. 
All of the above-described measures share the same ultimate aim: to guarantee the idea of political equality. Political equality in this sense means more than the wellknown principle of "one person, one vote". It involves a consideration that everybody must have real opportunity to influence the outcome of the elections, and everybody must have the possibility to seek supporters. Simultaneously, members of the public are entitled to receive information about the rival arguments in order to be able to form a well-founded decision at the end of the campaign. ${ }^{11}$ These arguments highlight the crucial importance of the freedom of expression during campaign periods. Without this freedom, the fairness of political competition cannot be ensured. But all of these abovementioned values can evaporate, if well-endowed interests gain the opportunity to monopolize the "marketplace of ideas" and undermine the fair competition among the rival political viewpoints. But, while these limits aim to guarantee equality, they may restrict freedom of expression, as well. Therefore the real question is how to balance between these two competing principles.

It is often argued that the European and the so-called American approach offer different solutions to this problem. ${ }^{12}$ As the relevant manual published by the Council of Europe points out, the "European approach has been to accept restrictions to campaign expenditure on the grounds that freedom of expression does not entail the freedom to use wealth to get the less prosperous to listen to one's views. In addition, restrictions on campaign expenditures can be justified with a view to controlling the potentially disruptive role of money in politics." While European campaign finance is moving towards more restrictive regulation of campaign expenditure, this practice is in sharp contrast with the more permissive tradition in the United States, where spending by candidates is not limited (except for presidential candidates who voluntarily accept spending limits in exchange for public subsidies)."13

\section{Equality in the constitutional practice of the United States}

This myth of the so-called American approach, which so infamously prefers freedom of expression to the ideal of political equality, has its roots in the Buckley v. Valeo case. ${ }^{14}$ In Buckley, the Supreme Court examined the Federal Election Campaign Act and struck down the limits on campaign spending. While arguing for the unconstitutionality of the spending limits, the judges phrased the well-known anti-egalitarian argument, according to which "the ancillary governmental interest in equalizing the relative ability of individuals and groups to influence the outcome of elections serves to justify the ... expenditure ceiling. But the concept that

11 Dawood Y. Democracy, Power and The Supreme Court: Campaign Finance Reform in Comparative Context. International Journal of Constitutional Law, 2006, No. 2. p. 280.

12 The different attitudes are strongly highlighted by Jacob Rowbottom. Rowbottom J. Animal Defenders International: Speech, Spending, and a Change of Direction in Strasbourg. Journal of Media Law, 2013, No. 5. pp. 1-13.

13 Van Biezen I. Financing political parties and election campaigns - Guidelines. Strasbourg: Council of Europe Publishing, 2003, p. 29.

14 Decision of the Supreme Court of the United States, Case: Buckley v. Valeo, 424 US 1 (1976). 
government may restrict the speech of some elements of our society in order to enhance the relative voice of others is wholly foreign to the First Amendment..." But, as Ronald Dworkin highlighted, in the same decision the Court upheld the contribution limits, and "it can be justified only on the assumption that Congress has the power to limit the political activity of some people in order to safeguard the citizen equality of others." ${ }^{5}$

Other decisions of the U.S. Supreme Court underline even more expressly, how significant the ideal of political equality has became in its practice. Stellar example of this development is the Austin decision, ${ }^{16}$ in which the Court argued that a regulation, which banned campaign expenditures by profit-oriented corporations, could be justified, as it aimed at a "different type of corruption in the political arena: the corrosive and distorting effects of immense aggregations of wealth that are accumulated with the help of the corporate form."

A weak majority overturned this decision recently in the Citizens United case, ${ }^{17}$ stressing that "Austin interferes with the "open marketplace" of ideas protected by the First Amendment." This argument is based on the instrumentalist justification of freedom of expression. According to the justices, freedom of speech makes it possible for the voters to gather information about the different viewpoints of the candidates, thus, guarantees the possibility of well-informed decision-making. Therefore, any regulation which limits the quantity of available speech on the marketplace of ideas endangers the decision-making process. In this sense, even the ideas of corporations may prove valuable.

At the same time Justice Stevens in his concurring opinion stated that "the interests of nonresident corporations may be fundamentally adverse to the interests of local voters. Consequently, when corporations grab up the prime broadcasting slots on the eve of an election, they can flood the market with advocacy that bears "little or no correlation" to the ideas of natural persons or to any broader notion of the public good. The opinions of real people may be marginalized." Thus, those who argue for the ban on corporate spending, state that motivated corporate interests may be able to monopolize the marketplace of ideas, hence making it increasingly difficult for those with lesser financial resources to transmit their messages to the voters.

\section{ECtHR: in favour of political equality?}

The problem of campaign spending is also well-known in the case law of the ECtHR. The last time in the Animal Defenders International v. The United Kingdom case ${ }^{18}$

15 Dworkin R. Political Equality. In Dworkin R. Sovereign Virtue. The Theory and Practice of Equality. Cambridge - London: Harvard University Press, 2000, p. 373.

16 Decision of the Supreme Court of the United States, Case: Austin v. Michigan Chamber of Commerce, 494 US 652 (1990).

17 Decision of the Supreme Court of the United States, Case: Citizens United v. Federal Election Commission, 558 US 310 (2010).

18 Judgment of European Court of Human Rights, Case No. 48876/08 Animal Defenders International v. The United Kingdom. 
the Court examined the interference of a contracting state's, namely, the United Kingdom's law on political activity with Article 10 of the Convention. The facts of the case were, as follows, that a small civil organisation, an NGO, the Animal Defenders International, which had the aim of protecting the animals from abuse, intended to begin a campaign under the name of "My Mate is a Primate" and wished to broadcast a short (20 seconds) television ad as part of this campaign. The British broadcasting authority found, that the ADI's aims were "wholly or mainly political in nature" and prohibited the advertising under the Communications Act (enacted in 2003), which in its Article 321 prohibits broadcasting almost every form of political ads, not just within campaign periods but also beyond those periods, and not just by public broadcasting services but also by private broadcasters, in every kind of broadcast media. In brief, these rules can be considered as blanket ban on political advertising in broadcast media. The ultimate aim of the Act was to protect the integrity of the political debate in the society. Thereby, the legislator meant to prevent the distorting effect of huge amounts of money on the political decision-making process.

After the decision of the broadcasting authority, the Animal Defenders issued proceedings seeking a declaration of incompatibility under Section 4 of the Human Rights Act and stated that the full prohibition on paid political advertising on television and radio was incompatible with Article 10 of the Convention. The Animal Defenders argued that the full prohibition was too broadly defined and banned communication, which should be protected under the Convention, so the ban must have been considered as disproportionate. However, the British courts rejected the arguments of the NGO. In their decisions they stated that "the rationale for the prohibition was to preserve the integrity of the democratic process by ensuring that the broadcast media were not distorted by wealthy interests in favour of a certain political agenda"19 Baroness Hale, a member of the House of Lords added that "our democracy is based upon more than one person one vote. It is based on the view that each person has equal value." Consequently, the NGO started proceedings in the ECtHR against the United Kingdom.

A highly divided Court concluded that the norms in question did not interfere with Article 10 of the Convention. In its argumentation, the majority at first stated that the "essence of democracy is to allow diverse political programmes to be proposed and debated..." and that "situation whereby a powerful economic or political group in society is permitted to obtain a position of dominance over the audiovisual media ... undermines the fundamental role of freedom of expression in a democratic society". Based on these principles, the judges refused those arguments, which called into question the proportionality of the rules at stake, stating that the prohibition was circumscribed to address the precise risk of distortion the State wished to avoid and that the rules in question were "considered to go to the heart of the democratic

19 Judgment of European Court of Human Rights, Case: 48876/08 Animal Defenders International v. The United Kingdom [17]. 
process." ${ }^{20}$ Paraphrasing the Animal Defenders' argument that "the Government could have narrowed the scope of the prohibition to allow advertising by social advocacy groups outside of electoral periods", the Court accepted the conclusions of the British judges that a less restricting rule would raise the risk that wealthy bodies with political agendas were able to circumvent the norms with the help of social advocacy groups created for that particular purpose. The Court also remarked that the Contracting States should be allowed to consider their own democratic visions when they regulate such advertising activity.

\section{Conclusion}

This decision of the ECtHR was heralded as the instance in which the European judges avoided the very pitfall, which trapped their American colleagues, and as a European victory of political equality, ${ }^{21}$ while, in fact, they did nothing else but allowed a blanket ban on political speech - both during and outside campaign period. It is highly questionable, whether this approach could help to guarantee political equality. As I have already elaborated, political equality also ensures that everybody has a real opportunity to influence the outcome of the elections, or, wording it differently: everybody must have a real opportunity to spread his or her views regarding political questions. On the other hand, political equality means that everybody is entitled to receive information about the different, rival arguments in order to be able to form a considered decision at the end of the campaign. This blanket ban, which does not differentiate between corporations with deep pockets and small, single issue groups, surely does not foster the realization of political equality in this sense.

\section{BIBLIOGRAPHY}

\section{Literature}

1. Dawood Y. Democracy, Power and The Supreme Court: Campaign Finance Reform in Comparative Context. International Journal of Constitutional Law, 2006, No. 2, pp. 269-293.

2. Dworkin R. Political Equality. In Dworkin Ronald: Sovereign Virtue. The Theory and Practice of Equality. Cambridge - London: Harvard University Press, 2000.

3. Pridham G. The European Union, democratic conditionality and transnational party linkages: The case of Eastern Europe. In: Grugel Jean (ed.). Democracy without Borders. Transnationalization and conditionality in new democracies. London and New York: Routledge, 1999, pp. 59-75.

${ }^{20}$ Judgment of European Court of Human Rights, Case: 48876/08 Animal Defenders International v. The United Kingdom [117].

21 See the early comment by Jacob Rowbottom: "The decision in Animal Defenders International has come as a surprise to me, but - and many will disagree with me on this point - it is a pleasant surprise. It is one in which the Strasbourg Court has moved away from its earlier jurisprudence and emphasized the importance of insulating political debate from the inequalities in wealth." Jacob Rowbottom. Surprise ruling? Strasbourg upholds the ban on paid political ads on TV and Radio. Available at https://ukconstitutionallaw.org/2013/04/22/jacob-rowbottom-a-surprise-rulingstrasbourg-upholds-the-ban-on-paid-political-ads-on-tv-and-radio/ [last viewed August 28, 2016]. 
4. Rawls J. Political Liberalism, Expanded Edition. New York: Columbia University Press, 2005.

5. Rowbottom J. Animal Defenders International: Speech, Spending, and a Change of Direction in Strasbourg. Journal of Media Law, 2013, No. 5, pp. 1-13.

6. Timus N. The Impact of Democracy Promotion in Party Financing in the East European Neighbourhood. European Integration Online Papers, 2010, No. 3, pp. 1-27.

7. Van Biezen I. Molenaar Fransje: The Europeanisation of Party Politics? Competing Regulatory Paradigms at the Supranational Level. West European Politics, 2012, 16 April, No. 3, pp. 632-656.

8. Van Biezen I. Financing political parties and election campaigns - Guidelines. Strasbourg: Council of Europe Publishing, 2003.

9. Walecki M. The Europeanization of Political Parties: Influencing the Regulations on Political Finance. EUI Working Papers, 2007, No. 29, pp. 1-20.

10. Whitehead L. Democratic Regions, Ostracism and Pariahs. In: Whitehead Laurence (ed.). The International Dimensions of Democratization: Europe and the Americas. Oxford - New York: Oxford University Press, 1996.

\section{Legislative acts}

1. Code of Good Practice in the Field of Political Parties by European Commission for Democracy Through Law (Venice Commission) CDL-AD(2009)002.

2. Commission Delegated Regulation (EU, Euratom) 2015/2401 of 2 October 2015 on the content and functioning of the Register of European political parties and foundations.

3. Guidelines and Report on the Financing of Political Parties by the Venice Commission CDL-INF (2001)8.

4. Opinion of the Prohibition of Financial Contributions to Political Parties From Foreign Sources adopted by the Venice Commission CDL-AD (2006)014.

5. Recommendation $\operatorname{Rec}(2003) 4$ of the Committee of Ministers to member states on common rules against corruption in the funding of political parties and electoral campaigns.

6. Regulation (EC) No. 1524/2007 of the European Parliament and of the Council of 18 December 2007 amending Regulation (EC) No 2004/2003 on the regulations governing political parties at European level and the rules regarding their funding.

7. Regulation (EC) No. 2004/2003 of the European Parliament and of the Council of 4 November 2003.

\section{Legal practice}

1. Decision of the Supreme Court of the United States, Case: Austin v. Michigan Chamber of Commerce, 494 US 652 (1990).

2. Decision of the Supreme Court of the United States, Case: Buckley v. Valeo, 424 US 1 (1976).

3. Decision of the Supreme Court of the United States, Case No. Citizens United v. Federal Election Commission, 558 US 310 (2010).

4. Judgment of European Court of Human Rights, Case No. 48876/08 Animal Defenders International v. The United Kingdom.

\section{Other sources}

Rowbottom Jacob: Surprise ruling? Strasbourg upholds the ban on paid political ads on TV and Radio. Available at https://ukconstitutionallaw.org/2013/04/22/acob-rowbottom-asurprise-ruling-strasbourg-upholds-the-ban-on-paid-political-ads-on-tv-and-radio/ [last viewed August 28, 2016]. 
Janis Grasis, Dr. iur.

BA School of Business and Finance, Latvia

\title{
COMPLIANCE OF THE LATVIAN PERSONAL INCOME TAX SYSTEM TO PREAMBLE OF THE SATVERSME (CONSTITUTION) OF THE REPUBLIC OF LATVIA AND INTERNATIONAL OBLIGATIONS OF THE REPUBLIC OF LATVIA
}

\begin{abstract}
Summary
Preamble of the Satversme provides that "Latvia is a democratic, socially responsible and national state... solidarity, justice, honesty, work ethic and family are the foundations of a cohesive society." Preamble of the Satversme is the basis for legal actions by state in order to implement it in real life for improvement of people's welfare. Latvian personal income tax system discriminates persons with low income and employees in comparision with persons receiving income from capital. The author recommends to reform the existing flat-tax taxation system, to increase tax burden of persons, who receive their income from capital and to resume calculation of the minimum monthly amount of money required to live in Latvia.
\end{abstract}

Keywords: socially responsible, solidarity, social justice, progressive tax income.

The Constitutional Court of the Republic of Latvia on November 2, 2006 in the case No. 2006-07-01 already stated: "Latvian constitutional legislator has defined several social rights in Satversme. Therefore, legislator has determined that Latvia is socially responsible state, i. e., the state, which in its legislation, administration and administration of justice tries to achieve maximum social justice to the greatest extent possible. The purpose of the socially responsible state is to equate the most essential social distinctions in the society and to ensure adequate living standards for each group of the persons." By this decision, the Constitutional Court of the Republic of Latvia recognized that the principle of socially responsible state also works in Latvia. The term "socially responsible state" includes the following elements: the state is obliged to ensure a standartd of living worthy of human beings; this includes ensuring social assistance and basic services, as well as accessibility of educational services, health care, social care and access to cultural events; the state is obliged to protect people against social risks; the state is obliged to be concerned about social justice, including concern about equating social differences, protecting the impecunious and ensuring equal opportunities; the country residents must be linked with society,

"Par likuma "Grozījumi Valsts sociālo pabalstu likumā" 1. panta daḷas, ar kuru Valsts sociālo pabalstu likumā ieviests jauns 7. panta pirmās dal̦as 3. punkts, un 2. panta atbilstïbu Latvijas Republikas Satversmes 110. pantam": Latvijas Republikas Satversmes tiesas 2006. gada 2. novembra tiesas spriedums lietā Nr. 2006-07-01. Latvijas Vēstnesis, 2006. 7. novembris, Nr. 177. 
which means that people haves obligations vis-à-vis other people. ${ }^{2}$ In the practice of the Constitutional Court it was explained that "The principle of socially responsible state means that state is obliged to establish sustainable and balanced policies to ensure public welfare. The country must ensure a balance between its financial capabilities and not just personal rights in the social area, but also a need to ensure the welfare of entire society, creating legal regulations that are aimed at sustainable development of the country". ${ }^{3}$ As it is indicated also by Ringolds Balodis and Jānis Pleps, "Under conditions of economic decline, the criterion that is used to evaluate disputed norms in relation to constitutionality and overall legal principles is whether the solution chosen by legislator is socially responsible".

Latvian Parliament - Saeima adopted amendments to the Satversme (Constitution of the Republic of Latvia) introducing Preamble on June 19, 2014. The newly born Preamble reaffirms that "Latvia as democratic, socially responsible and national state is based on the rule of law and on respect for human dignity and freedom; ... Loyalty to Latvia, the Latvian language as the only official language, freedom, equality, solidarity, justice, honesty, work ethics and family are the foundations of a cohesive society." It means that terms like "socially responsible state", "solidarity" and "justice" must also be related to direct taxation issues. The Preamble of the Satversme prescribes the duties of the state in the Latvian legal system. As indicated by Jannis Pleps, "Particular state duties emerge from Preamble of the Satversme, which must be ensured with policies of the state, normative acts and financial support. Preamble of the Satversme is a basis for legal actions by state in order to implement it in real life for improvement of welfare for the people. ${ }^{6}$

Let us look have a brief look at the international obligations of the Republic of Latvia. International Covenant on Economic, Social and Cultural Rights from December 16, 1966 was ratified by the Supreme Council of Republic of Latvia on May 4, 1990; it entered into force on July 14, 1992 in Latvia. The Article 7 of this convention states that "The States Parties to the present Covenant recognize the right of everyone to the enjoyment of just and favourable conditions of work which ensure, in particular:

(a) Remuneration which provides all workers, as a minimum, with:

(i) Fair wages and equal remuneration for work of equal value without distinction of any kind, in particular women being guaranteed conditions of work not inferior to those enjoyed by men, with equal pay for equal work;

(ii) A decent living for themselves and their families in accordance with the provisions of the present Covenant;

(b) Safe and healthy working conditions;

2 Kovaļevska A. Sociāli atbildīgas valsts princips. Jurista vārds, 2008. 26. augustā. 10.-13. lpp.

3 Latvijas Republikas Satversmes tiesas 2010. gada 15. marta tiesas spriedums lietā Nr. 2009-44-01. Latvijas Republikas Satversmes tiesas spriedumi 2009. Rīga: Tiesu nama aǵentūra, 201.1

4 Balodis R. and Pleps J. Financial crisis and the Constitution in Latvia. In: Constitution in the Global Financial Crisis: A Comparative Analyses. London and New York: Routledge, 2013, p. 124.

5 Latvijas Republikas Satversme: LR likums. Latvijas Vēstnesis, 1993. 1. jūlijs, Nr. 43; attiecīgie grozijumi Latvijas Vēstnesis, 2014. 8. jūlijs, Nr. 131.

6 Pleps J. Satversmes ievada piemērošana. Jurista Vārds, 2014. 5. augustā, 4.-8.lpp. 
(c) Equal opportunity for everyone to be promoted in his employment to an appropriate higher level, subject to no considerations other than those of seniority and competence;

(d) Rest, leisure and reasonable limitation of working hours and periodic holidays with pay, as well as remuneration for public holidays".

Part 1 of the Article 11 of the International Covenant prescribes that "The States Parties to the present Covenant recognize the right of everyone to an adequate standard of living for himself and his family, including adequate food, clothing and housing, and to the continuous improvement of living conditions. The States Parties will take appropriate steps to ensure the realization of this right, recognizing to this effect the essential importance of international co-operation based on free consent." According to the academic teachings, the right of everyone to an adequate standard of living for himself or herself and the family is not limited to having adequate housing, food and clothing, but also encompasses being a full-fledged member of society able to fullfill one's basic needs. ${ }^{8}$ The Constitutional Court of the German Federal Republic (The First Senate) in its verdict of May 29, 1990 approved that "Personal income tax applies only to those incomes of the family, which are execeeding the minimum threshold for living expenses. The incomes below this threshold must be free from any income tax."

Latvian personal income tax system was created in the middle of 1990s and its main principles remained without significants changes since then. The Republic of Latvia still has the flat tax rate system since creation of the existing taxation system. It's rate has been varied from $26 \%$ until $23 \%$ shortly before preparing this publication.

Latvian Personal Income Tax (hereinafter - Tax) is a Tax, which is imposed on the income acquired by a natural person, and it consists of:

1) salary tax calculated from the income acquired by the employee and paid by the employer;

2) fixed income tax regarding income from economic activity;

3) tax for income from economic activity where it is not the object of the enterprise income tax, and tax from other sources of income;

4) tax for income from capital, including tax from an increase in capital;

5) licence fees for the performance of separate types of economic activities;

6) the parts of the micro-enterprise tax in accordance with the Micro-enterprise Tax Law;

International Covenaent on Economic, Social and Cultural Rights: international agreement. Available at http://www.ohchr.org/EN/ProfessionalInterest/Pages/CESCR.aspx [last viewed August 16, 2016].

8 Eide A. The Rights to an Adequate Standard of Living Including the Right to Food. In: Economic, Social and Cultural Rights. A Textbook. Dordrecht, Boston, London: Martinus Nijhoff Publishers, 2001, p. 133.

9 Citēts pēc: Lazdins J.Taisnīguma principa ievērošana iedzīvotāju ienākumu aplikšanā ar iedzīvotāju ienākuma nodokli. In: Latvijas Universitātes raksti, 2008, 740. sēj. 101. lpp. 
7) seasonal agricultural worker income tax..$^{10}$ The existing flat Tax rate to be paid from the annual taxable income is 23 per cent. The rate of Tax for income from capital, which is not an increase in capital, is 10 per cent; the rate of Tax for an increase in capital is 15 per cent. ${ }^{11}$ These tax rates show discrimination between employees, who are forced to pay a higher tax, and persons who receive their income from capital or an increase of capital. This contradicts the concept of the socially responsible state and principles of solidarity and justice indicated in the Preamble of the Satversme.

Another problem is related to the minimum consumer basket of goods and services and the minimum necessary amount of money in order to ensure it. Following the decision of the Cabinet of Ministers, Central Statistical Bureau does not calculate this amount since January $1,2014 .{ }^{12}$ This amount of money was calculated in accordance with outdated regulations from 1991. The latest calculated amount was 252 euro and 19 eurocents per month in December, 2013. Since this amount of money was calculated on the basis of a very old methodology, this amount does not correspond to the real necessary expenses of person per one month. During the fiscal year of 2016, Latvian government has established the minimum bruto salary - 370 euro. To start a calculation of neto amount after personal income tax and social contributions, the persons receive 272 euro and 24 eurocents. ${ }^{13}$ This is above the real minimum amount necessary for normal living conditions in 2016 in Latvia. Consequently, the government is taxing persons with a very low income contrary to the basic principles declared in the Preamble of Satversme and international obligations of the Republic of Latvia. According to the recent economical surveys, the average income per family was 425 lats $(604,72$ euros)for $90 \%$ of the Latvian population, whereas in case of the richest part of the society 3019 lats (4295,65 euros) or 7 times more. ${ }^{14}$ The Ombudsman of the Republic of Latvia J. Jansons has also emphasized that Latvia is not a socially responsible state, especially considering unfair salary; ${ }^{15}$ it was also indicated in his letter to the State President. ${ }^{16}$

10 Par iedzīvotāju ienākuma nodokli: LR likums. Latvijas Vēstnesis, 1995. 1. jūlijs Nr. 32.

11 Ibid.

12 Noteikumi par valsts statistiskās informācijas programmu 2014. gadam: MK noteikumi Nr. 1474. Latvijas Vēstnesis, 2013. 20. decembrī.

13 Available at http://www.vid.lv/algas-kalkulators.html [last viewed August 19, 2016].

${ }^{14}$ Litvins G. Sociāli atbildīga valsts un sabiedrība. Jurista vārds, 2012. 23. oktobrī, 2. lpp.

15 Tiesïbsargs: Latvija nav sociāli atbildīga valsts. Available at http://www.tvnet.lv/zinas/ viedokli/554941-tiesibsargs_latvija_nav_sociali_atbildiga_valsts [last viewed October 5, 2016].

16 Letter from Ombudsman to the State President No. 1-12/5, dated July 14, 2015. Available at http://www.tiesibsargs.lv/files/content/vestules/Vestule\%20Valsts\%20prezidentam Socialais\%20 taisnigums_14.07.2015.pdf [last viewed 05.10.2016]. 
The abovementioned unfair taxation system influences also the GINI index ${ }^{17}$ of Latvia, which was $35,5 \%$ in $2014^{18}$ - one of the highest between countries of the European Union Member States. According to the latest statistical data, 35000 of employees receiving not more than minimum salary. ${ }^{19}$

Many international experts have indicated this discrimination. For example, before Latvia entered Organization of Economical Cooperation and Developments (hereinafter - OECD), the OECD tax experts revised Latvian tax system, including the personal income tax. As they indicated, "The tax system is skewed toward labour taxes and is relatively regressive. In particular, it is characterised by a relatively high tax wedge for low-income earners which undermines their employability in formal. The labour tax wedge stems from high social security contributions ... plus the personal income flat tax (23\%)." ${ }^{20}$ Despite the recomendations of the OECD tax experts, on the way towards full membership in OECD, Latvian government and Saeima introduced a new tax - the Solidarity Tax. ${ }^{21}$ The total tax burden of employees was increased by this new tax starting from taxation year of 2016; unfortunately, this law does not affect the persons who receive income from capital or an increase of capital. Consequently, it is manifest that the existing personal income tax system does not correspond to the concept of socially responsible state, where the state tries to achieve the maximum social justice.

There has been a rather persisting discussion, whether to introduce a progressive tax system for personal income tax. ${ }^{22}$ Reviewing the taxation policy planning documents of the Republic of Latvia Ministry of Finance, for example "The purposes, main principles and the achievable results in years 2013-2016"23 (Ministry of Finance (2015), we could find the following:

1) one of the main purposes of Latvian taxation policy is fairness of the income tax system;

17 The Gini index measures the extent, to which the distribution of income (or, in some cases, consumption expenditure) among individuals or households within an economy deviates from a perfectly equal distribution. The Gini index measures the area between the Lorenz curve and the hypothetical line of absolute equality, expressed as a percentage of the maximum area under the line. A Gini index of zero represents perfect equality and 100 indicates perfect inequality.

18 Gini index in Europe. Available at http://www.pordata.pt/en/Europe/Gini+index+(percentage)1541 [last viewed October 5, 2016].

19 Minimālās algas saṇēmēju skaits nemainās - to saṇem 35000 strādājošo. Available at http:// financenet.tvnet.lv/zinas/605925-minimalas_algas_sanemeju_skaits_nemainas_to_sanem 35_000_stradajoso [last viewed August 25, 2016].

20 OECD Economic Surveys Latvia. OECD, February 2015, p. 21.

${ }^{21}$ Solidaritātes nodokḷa likums: LR likums. Latvijas Vēstnesis, 2015.18. decembris. Nr. 248.

22 Bojārs J., Grasis J. Necessity of Introduction of the Progressive Income Tax System: Case of Latvia. In: Economics, Cocial Sciences and Information management. Proceedings of the 2015 International Congress on Economics, Social Sciences and Information Management; CRC Press, 2015, pp. 85-91.

23 Ministry of Finance of the Republic of Latvia (2015). "The purposes, main principles and the achievable results in years 2013-2016". Available at http://www.fm.gov.lv/lv/sadalas/nodoklu politika/Nodoklu_politikas_merki_pamatprincipi_un_sasniedzamie_rezultati_2013_2016_ gadam/ [last viewed October $\overline{5}, 2016]$. 
2) since one of the main principles is the abovementioned horizontal fairness principle (flat tax rate for the same tax base), which contradicts the vertical fairness principle (amount of tax paid depends on the income level of the taxpayer). Ministry of Finance indicates that the vertical fairness principle is too costly for the taxpayers. It appears ridiculous in the period of information technologies;

3) one of the achievable results is the reduction of tax burden for the labourers and employees with children.

The ability-to-pay principle underpins the modern tax law systems. Already a few centuries back the economist Adam Smith wrote: "The subjects of every state ought to contribute towards the support of the government, as nearly as possible, in proportion to their respective abilities." ${ }^{24}$ It is not essential for a progressive income tax system to have a large number of income tax rates, nor even very high ones. If there are at least two rates, one of which can be the nil rate applicable below a minimum threshold, at which tax has to be paid, the system has some progressivity. Given that poor people will spend a higher proportion of their income on the necessities than the people with a higher income, there is a justification for progressivity and it is a concept embedded into the modern tax systems. This is sometimes referred to as principle of vertical equity. ${ }^{25}$

On June 15, 2016, the high-level working seminar of the representatives of the government, social and cooperation partners and the experts of the World Bank (WB), the Organisation for Economic Development and Co-operation (OECD) and the European Commission (EC) was held regarding Latvia's tax policy challenges in the medium term planning period. The representative of the Directorate General Taxation and Customs Union of the EC Milena Mathe, in her presentation, spoke of the tax policy challenges in the European Union Member States, and invited Latvia to continue measures for reducing tax burden placed upon the low income groups and strengthening the capacity of tax adminstration. All the experts expressed their view concerning necessary changes for Latvian taxation system and the need for solidarity tax reform. ${ }^{26}$

\section{Conclusions}

Personal income tax system of the Republic of Latvia must be reformed to become consistent with the Preamble of Satversme and international obligations of the Republic of Latvia. Personal income tax must be in accordance with abilityto-pay principle, which ensures solidarity and continuous improvement of living

24 Smith A. The Nature \& Causes of the Wealth of Nations, Book V, Ch. 11, Part II, 1776.

25 Freedman J. Ability to pay tax. In: The New Oxford Companion to Law. Oxford University Press, 2008, pp. 1154-1155.

26 Sustainability of Latvia's Tax Policy Discussed at a Seminar. Available at http://www.fm.gov.lv/ en/news/52864-sustainability-of-latvias-tax-policy-discussed-at-a-seminar [last viewed August 17, 2016]. 
conditions for persons with relative low income according to the Article 11 of the UN International Covenant on Economic, Social and Cultural Rights.

One of the possible reforms to make personal income tax system in the Republic of Latvia correspond to the status of a socially responsible state, as it is stated in the Preamble of Satversme, is to introduce a progressive taxation system. My proposal is to do this step by step in the following way:

1) as Latvian government had plans to reduce step by step personal income tax flat rate from $23 \%$ to $15 \%$, the introduction of the progressive income tax is comparatively simple: by establishing a threshold of, for example, 1500 euro per month (18 000 Euro per year), up to this threshold Latvian government would continue to reduce the income tax rate; for the income above 1500 per month to retain the existing flat rate at $23 \%$. Ultimately, there would be 2 tax rates: $15 \%$ and $23 \%$. To compare two employees, one earns 720 euro per month; another - 3000 euro monthly. If the income tax is reduced by $1 \%$ for both of them similarly, the gain of the first employee is 7.20 euro, but for the the second employee - 30 euro. It means that the person with a higher salary receives more benefits from the tax reduction. If there is a progressive tax system, the person with a higher income pays proportionally more.

2) simultaneously, as capitals gains tax for individuals is currently at the level of $10-15 \%$, an additional capital gains tax at the level of $8-13 \%$ could be established. It means that after introduction of the progressive income tax system, the richest residents of the country would pay $23 \%$ income tax from all their income, whether salary or capital gains.

The Cabinet of Ministers must elaborate new rules for calculating the necessary minimum amount of money required for living in Latvia. This amount of money must be free of any taxation, providing to any person in Latvia the minimum amount of money to ensure the very basic living standard conditions according to the Preamble of the Satversme and international obligations of the Republic of Latvia.

\section{Bibliography}

\section{Literature}

1. Balodis R. and Pleps J. Financial crisis and the Constitution in Latvia. In: Constitution in the Global Financial Crisis: A Comparative Analyses. London and New York: Routledge, 2013, p. 124.

2. Bojārs J., Grasis J. Necessity of Introduction of the Progressive Income Tax System: case of Latvia. In: Economics, Cocial Sciences and Information management. Proceedings of the 2015 International Congress on Economics, Social Sciences and Information Management. CRC Press, 2015, pp. 85-91.

3. Eide A. The Rights to an Adequate Standard of Living Including the Right to Food. In: Economic, Social and Cultural Rights. A Textbook. Dordrecht, Boston, London: Martinus Nijhoff Publishers, 2001, p. 133.

4. Freedman J. Ability to pay tax. In: The New Oxford Companion to Law. Oxford University Press, 2008, pp. 1154-1155. 
5. Ministry of Finance of the Republic of Latvia. "The purposes, main principles and the achievable results in years 2013-2016”. 2015. Available at http://www.fm.gov.lv/lv/ sadalas/nodoklu_politika/Nodoklu_politikas_merki_pamatprincipi_un_sasniedzamie _ rezultati_2013_2016_gadam/ [last viewed October 5, 2016].

6. Lazdiņš J. Taisnīguma principa ievērošana iedzīvotāju ienākumu aplikšanā ar iedzīvotāju ienākuma nodokli (Observance of the principle of Justice levying Personal Income Tax). In: Latvijas Universitātes raksti, 2008, 740. sēj. 101. lpp.

7. Litvins G. Sociāli atbildīga valsts un sabiedrība (Socially liable state and the society). Jurista vārds, 2012. 23. oktobrī, 2. lpp.

8. Koval̦evska A. Sociāli atbildīgas valsts princips(The principle of socially liable state). Jurista vārds, 2008. 26. augustā. 10.-13. lpp.

9. Pleps J. Satversmes ievada piemērošana (Application of the Preamble of the Satversme). Jurista Vārds, 2014. 5. augustā, 4.-8. lpp.

10. Smith A. The Nature \& Causes of the Wealth of Nations, Book V, Ch. 11, Part II, 1776.

\section{Legislative acts}

1. Noteikumi par valsts statistiskās informācijas programmu 2014. gadam: MK noteikumi Nr. 1474. Latvijas Vēstnesis, 2013. 20. decembrī.

2. Par iedzīvotāju ienākuma nodokli: LR likums. Latvijas Vēstnesis, 1995. 1. jūlijs, Nr. 32.

3. "Par likuma "Grozijjumi Valsts sociālo pabalstu likumā" 1. panta dạ̦as, ar kuru Valsts sociālo pabalstu likumā ieviests jauns 7. panta pirmās daļas 3. punkts, un 2. panta atbilstîbu Latvijas Republikas Satversmes 110. pantam": Latvijas Republikas Satversmes tiesas 2006. gada 2. novembra tiesas spriedums lietā Nr. 2006-07-01. Latvijas Vēstnesis, 2006. 7. novembris, Nr. 177.

4. Solidaritātes nodokḷa likums: LR likums. Latvijas Vēstnesis, 2015. 18. decembris. Nr. 248.

\section{Other sources}

1. Gini index in Europe. Available at http://www.pordata.pt/en/Europe/Gini+index+ (percentage)-1541 [last viewed October 5, 2016].

2. Minimālās algas saṇēmēju skaits nemainās - to saṇem 35000 strādājošo. (No changes in the amount of the receivers of minimum salary - it is still 35000 labourers). Available at http://financenet.tvnet.lv/zinas/605925-minimalas_algas_sanemeju_skaits_nemainas to_sanem_35_000_stradajoso [last viewed October 5, 2016]. International Covenant on Economic, Social and Cultural Rights. Available at http://www.ohchr.org/EN/ ProfessionalInterest/Pages/CESCR.aspx [last viewed October 5, 2016].

3. Letter from Ombudsman to the State President No. 1-12/5 dated July 14, 2015. Available at http://www.tiesibsargs.lv/files/content/vestules/Vestule\%20Valsts\%20prezidentam _ Socialais\%20taisnigums_14.07.2015.pdf [last viewed October 5, 2016].

4. OECD Economic Surveys Latvia. OECD, February 2015, p. 21.

5. Tiesībsargs: Latvija nav sociāli atbildīga valsts (Ombudsman: Latvia is not a socially liable state). Available at http://www.tvnet.lv/zinas/viedokli/554941-tiesibsargs_latvija_nav_ sociali_atbildiga_valsts [last viewed October 7, 2016]. 


\section{SECTION 6}

LEGAL PERSONS

AS PARTICIPANTS OF LEGAL

PROCEEDINGS AND THEIR

RIGHT TO A FAIR PROCEDURE 
Edvins Danovskis, Dr. iur.

University of Latvia, Latvia

\title{
THE CONCEPT OF FAULT IN LATVIAN ADMINISTRATIVE LAW
}

\begin{abstract}
Summary
The article outlines the concept of fault in the Latvian administrative law, namely, administrative offence law, competition law and finance law. The main argument of the article is that in the administrative law intent and negligence as forms of fault in the sense of mental attitude are irrelevant both theoretically and practically. Instead, the fault as a concept should be used to describe the link between a person and the delinquent activity or inactivity, including legally relevant facts that can exclude application of administrative liability.
\end{abstract}

Keywords: Fault, intent, negligence, administrative law, administrative liability, nulla poena sine culpa.

\section{Introduction}

Fines and other punishments imposed by the authorities and legal regulation thereof form a rather significant part of the Latvian administrative law. Although most of such fines are imposed for administrative offences regulated by the Code of Administrative Offences, ${ }^{1}$ application of some fines is also regulated by other laws. In a way they all belong to a wider sphere of legal regulation - so-called penal law - which is, of course, dominated by the criminal law. There are legal principles common for all penal law (for instance, non bis in idem), but there are also several differences. One of such differences is the concept of fault. Therefore, the purpose of this article is to outline the use and content of this notion in the administrative law (except disciplinary law of the public servants). This is particularly topical due to the fact that a new law on administrative offences ${ }^{2}$ is being prepared for adoption in the Parliament.

The main research method used in this article is analysis and comparison of the concept of fault in several branches of administrative law. Another methodological tool is a review of court judgments in administrative offence cases. This method is further explained in the article. This article is intended to give only conceptual conclusions of the notion of "fault" in the administrative law. A more detailed study is necessary to discover and develop elaborate and exhaustive list of conditions excluding a person from administrative liability.

Latvijas Administratīvo pārkāpumu kodekss. Ziṇotājs, 1984. 20. decembris, Nr. 51.

Administratīvo pārkāpumu procesa likums (likumprojekts). Available at http://titania.saeima.lv/ LIVS11/saeimalivs11.nsf/0/C09FFF1B23A17044C2257CDF0023B6DA?OpenDocument [last viewed August 30, 2016]. 


\section{Various meanings of the term "fault"}

The term "fault" is well known in many legal systems, although it is used in different intensity and even in different meanings. Perhaps the Latin term culpa is known in all European and Anglo-Saxon legal systems, but it is also true that there is no general agreement about what exactly this term comprises, for it is used in different meanings both in civil and criminal law. The English legal terminology uses the term "fault", whereas its synonym "guilt" is also used, though with a different meaning (the person is "guilty"/not "guilty"). In German Strafrecht there is a similar legal term - die Schuld. However, in the German legal language it is probably used less frequently than in the Russian legal system, where its linguistic analogue вина is regarded with an utmost importance in the criminal law. However, even within a single legal system the contents of this term can be ambiguous. This is also true of the Latvian legal system, where the term is used mainly in penal law (criminal law and administrative offence law).

The term "fault" in the Latvian legal system traditionally is used with utmost importance in the criminal law. In the criminal law, the fault is understood as a mental attitude of a person towards its illegal activity of inactivity and its material consequences (damage of property, harm, etc.). ${ }^{3}$ This explanation of the term is generally accepted and undisputed. ${ }^{4}$ In this sense, the fault is an element of the socalled "subjective part" of the criminal offence. In the theory of Latvian criminal law, four elements of a criminal offence (so-called "content of a criminal offence") must be established: object, objective part, subject and subjective part. This doctrinal approach to a criminal offence has been continued from the Soviet criminal law, where it has originally been introduced ${ }^{5}$ and is still widely used in the Russian theory of criminal law. ${ }^{6}$

However, the term "fault" is sometimes understood in a broader sense and comprises all legal facts necessary to conclude that a person has committed a criminal offence. ${ }^{7}$ In this sense, the term "fault" is used to express that a person is guilty and therefore criminally liable for the committed offence. This approach basically means that a person cannot be punished for what she has not done. Only in this sense the fault has some links with the presumption of innocence protected both constitutionally and in the European Convention of Human Rights. However, even the European Court of Human Rights has stated that the presumption of innocence in general does not demand intent or negligence (as a mental attitude) to be a precondition of liability: "[..] the Contracting States remain free [..] to define the constituent

3 Krastinš̌ U. Noziedzīga nodarījuma sastāvs un nodarījuma kvalifikācija. Teorētiskie aspekti. Rīga: Tiesu namu aǵentūra, 2014, p. 132.

4 Rozenbergs J. Vainas institūts krimināltiesībās un tā nozīme noziedzịgu nodarījumu kvalifikācijā. Promocijas darbs. Rīga: Latvijas Universitāte, 2012, pp. 20-21. Available at https://dspace.lu.lv/ dspace/bitstream/handle/7/5122/22890-Janis_Rozenbergs_2012.pdf? sequence $=1 \&$ isAllowed $=y$ [last viewed August 8, 2016].

5 Ibid., pp. 21-22.

6 Krastiņš U. Op.cit., p. 18.

7 Rozenbergs J. Op.cit. pp. 29-31; Krastiņš U. Op.cit., p. 133. 
elements of the resulting offence. In particular, and again in principle, the Contracting States may, under certain conditions, penalise a simple or objective fact as such, irrespective of whether it results from criminal intent or from negligence. Examples of such offences may be found in the laws of the Contracting States." 8 An analysis of the principle of nulla poena sine culpa in the practice of the European Court of Human Rights and the European Court of Justice also show that this principle is more related to procedural guarantees of the presumption of innocence than a principle of substantive penal law of a European level. ${ }^{9}$

Although historically administrative offence law in Latvia was drafted on the basis of the soviet criminal law and in many aspects legal principles of regulation of administrative offences (petty offence, ordnugswidrigkeiten) are similar to criminal law, the concept of fault in administrative law is significantly different from its understanding in the criminal law.

\section{The concept of fault in the administrative offence law}

In 1984, the Code of Administrative Offences was adopted. It was a considerable attempt by the soviet legal system to harmonize and codify the regulation of misdemeanour conduct. It should be noted that it was the first act of this kind, which set under one law both material and procedural rules regarding administrative offences. At that time, as well as today, it was evident that many of the principles governing criminal law should also be applied in relation to administrative offences. Therefore, general provisions on administrative offences in various aspects were similar or identical to the provisions contained in the Criminal Code of 1961. Part One of Article 9 of the Code of Administrative Offences states that "an administrative violation shall be acknowledged as an unlawful, blameable (committed with intent or through negligence) action or inaction [..]." The reference to the blame (fault) was identical to the one in the Criminal Code. Likewise, almost identical to the Criminal Code were the provisions contained in the Article 10 and 11, which defined intent and negligence. At that time, such approach seemed to be reasonable, because several offences (some of those offences who were committed only if material consequences (damage, etc.) were made) could be a result of negligence. Today, however, the concept of fault has transformed considerably and, curiously, without any alterations in the definition of the administrative offence.

In the 1990s, the Parliament quite rightly excluded from the Code of Administrative Offences all offences, which in their formulations contained material consequences, for instance, some kind of damage to property, etc. Today, nearly all the administrative offences are formal offences, that is, they are committed in the moment when an illegal activity or inactivity has been performed; no further material consequences

Judgment of the European Court of Human Rights of 7 October 1988 in Case Salabiaku v. France, para. 27.

9 See Panebianco G. The Nulla Poena Sine Culpa Principle in European Courts Case Law. In: Human Rights in European Criminal Law. New Developments in European Legislation and Case Law after the Lisbon Treaty. Springer, 2015, pp. 47-78. 
are needed in order to conclude that an offence has been committed. Most of the administrative offences provide administrative liability for non-compliance with law, regulations or bylaws. However, negligence as a form of fault is possible only with regard to those offences, which, in order to be committed, according to the formulation of the offence in the law, demand some material consequences, as well. Since in the Code of Administrative Offences today there are nearly no offences of this type, negligence as a form of fault has lost its importance. It is sometimes wrongly perceived in the praxis that negligence as a form of fault can also occur in formal offences. For instance, a person has been driving a car with an expired technical safety certificate and claims that he has been negligent and has forgotten that the safety certificate has expired. Such perception in the Latvian administrative offence law is wrong. Activity of a person - driving a car - can be committed only intently (if the person drives the car then he intends to do so, unless under some psychical condition). Even if a person has indeed forgotten to apply for a new safety certificate, this has no influence to the form of fault, for the mental attitude of a person as to whether her activity is legal or not is irrelevant, provided that the relevant legal regulations have been duly adopted and published. Legality of the activity or inactivity is an objective fact and it does not have any impact on the form of fault.

Another change that has proven to have a considerable impact on the concept of fault has resulted from the amendments to the Code of Administrative Offences of 17 June $1998,{ }^{10}$ which provided that administrative liability can also be applied to legal entities. Until that time, only natural persons were subjects of administrative liability. The amendments with regard to general possibility of applying administrative liability to legal entities stated, as follows: "In special cases provided for in this Code, legal persons shall be subject to liability for administrative violations." Since then, many formulations of offences have simply been amended with a reference that a legal person can also be punished for the offence. Hence, the same offence, for instance, failure to comply with safety standards for buildings, can be conducted by either natural persons or legal entities. According to the law, this means that the fault as a mental attitude towards an activity is a precondition to punish natural person, but in case of legal entities such precondition is neither possible nor needed. In practice, however, fault has no major significance even for natural persons.

Having examined all publicly available judgments in administrative offence cases of Regional Courts (Appellate Courts) of 2015, which mention word "negligence" (aiz neuzmanibas), only 65 of 777 judgments were selected by the search engine. ${ }^{11}$ From those 65 judgments only 6 judgments contained an analysis, whether the conduct of a natural person was carried out with intent or due to negligence. Only in three judgments it was wrongly concluded that the activity of a natural person can be carried out negligently. Therefore, neither in theory nor in practice there is a need to establish the form of fault. What matters in case of offence committed by a natural

10 Grozijumi Latvijas Administratīvo pārkāpumu kodeksā. Latvijas Vēstnesis. 1998. 8. jūlijs, Nr. 199/200.

11 The survey was made using the search engine. Available at https://manas.tiesas.lv/eTiesasMvc/ nolemumi [last viewed August 30, 2016]. 
person is the fact that a person who committed the offence was sane and that there were no other circumstances provided by the law that exclude liability.

While the law has not yet been properly modified, a new approach towards fault is offered by the legal scholarship. The fault should be understood as a legal term describing the link between the activity or inactivity and a person who commits those acts. In this sense the fault has two elements - objective element and subjective element. Objective element is the fact, that the activity or inactivity is attributable to a particular person. In this sense, the fault is understood in an everyday speech ("I am not guilty" /"it is not my fault" = "it was not I who committed the offence"). Subjective element describes the fact that the person was capable of understanding his behavior (sanity) and legally relevant facts, and that there are no other facts that exclude the possibility to punish the offender (force majeure, excusable mistake, etc.). ${ }^{12}$ There is no need to use the concept of fault in administrative offence law as a mental attitude towards the activity or inactivity and therefore to distinguish intent and negligence, because from the theoretical and, especially, practical point of view it is simply unnecessary.

In general, the standard for the subjective element of the fault should be the same both for natural persons and legal entities, because many administrative offences can be committed by both subjects and the standard of behavior prescribed by the legal regulations is identical for both natural persons and legal entities. This means that only such objective circumstances like force majeure or other conditions prescribed by the law may exclude the liability. However, in those offences where only natural persons are subjects, the scope of excuses can be wider. For instance, in certain situations the fact that a person has been or has not been aware of certain facts may still be relevant, if such facts point to circumstances that the person has had no objective option to avoid illegal activity. For instance, if a person drives a car and exceeds speed limit due to the sudden malfunction of the speedometer (the speedometer shows less speed) and he reasonably could not have been aware of the fact that he actually exceeded the speed limit, then such fact has a significance, since the person could not know that his activity at that moment was illegal. Therefore, the mental attitude of a natural person is important insomuch as the person has to be aware of legally relevant facts. In other cases, where legal entities can also be subjects of an offence, such excuses should have no significance, because the standard of behavior set by laws usually demand that a person operating in certain spheres must be aware of all legally relevant factors and failure to comply with those standards cannot exclude liability.

The reasonability of such an approach is more evident when turning to the liability imposed by government authorities on natural persons and legal entities in spheres like competition law, finance and tax law. Liability provided, for instance, in the Competition Law for breaches of competition regulations can be treated as administrative liability, but for formal reasons it is not an administrative offence (the offence is not listed in the Code of Administrative Offences).

12 Briede J., Danovskis E., Kovaļevska A. Administratīvās tiesības. Mācību grāmata. Rīga: Tiesu namu ağentūra, 2016, p. 213. 


\section{Fault in other areas of administrative law}

A notable example, which also illustrates the understanding of the fault in administrative law is the practice of the European Court of Justice in competition matters. Article 23 (1) and (2) of the Council Regulation No. 1/2003 of 16 December 2002 on the implementation of the rules on competition laid down in Articles 81 and 82 of the Treaty ${ }^{13}$ states that the Commission may by decision impose fines on undertakings and associations of undertakings where, either intentionally or negligently, they infringe certain competition rules. Formulation of intent and negligence might indicate that the Commission should prove that the breach was made either negligently or with intent. However, that is not the case. The practice of the European Court of Justice shows that words "intentionally or negligently" should be interpreted not as a particular precondition of liability, but rather stating that there is no need to pay attention to the subjective factors of the undertaking and explanations why the breach of rules has occurred.

The European Court of Justice has ruled that "in relation to the question whether an infringement has been committed intentionally or negligently and is, therefore, liable to be punished by a fine [..] it follows from the case-law of the Court that that condition is satisfied where the undertaking concerned cannot be unaware of the anticompetitive nature of its conduct, whether or not it is aware that it is infringing the competition rules of the Treaty." ${ }^{14}$ Wrongful perception of an undertaking that its behavior is legal is of no significance - "an undertaking which has infringed that provision may not escape imposition of a fine where the infringement has resulted from that undertaking erring as to the lawfulness of its conduct on account of the terms of legal advice given by a lawyer or of the terms of a decision of a national competition authority." ${ }^{15}$ Latvian Competition $\mathrm{Law}^{16}$ also contains no reference to the fault in either of its aspects. It simply defines what behavior is unlawful (actions, which restrict competition) and the fines that can be imposed. The issue of fault as a special precondition in competition cases in Latvia has not been relevant.

The same can be said about fines that are imposed on credit institutions by the Financial and Capital Market Commission. Chapter XV of The Law on Credit Institutions ${ }^{17}$ prescribes liability for many breaches of legal regulation and none of them mentions fault as a particular precondition. There is only one breach (submission of misleading information) that takes into consideration objective awareness of the person. However, even in this case the only legally relevant fact is that the credit institution has breached the normative provisions regulating its activities and that it had no legally legitimate excuses.

13 Council Regulation No. 1/2003 of 16 December 2002 on the implementation of the rules on competition laid down in Articles 81 and 82 of the Treaty. Official Journal. 2003. 4. January, L 001.

14 Judgment of the Grand Chamber of the European Court of Justice of 18 June 2013 in Case No. C-681/11 Shenker \& Co. AG et al., para. 37.

15 Ibid, para. 43.

16 Konkurences likums. Latvijas Vēstnesis. 2001. 23. oktobris, Nr. 151 (2538).

17 Kredītiestāžu likums. Latvijas Vēstnesis. 1995. 24. oktobris, Nr. 163 (446). 


\section{Conclusions}

1. In the Latvian administrative offence law the importance of fault as a mental attitude in the form of intent and negligence has gradually been diminished. This is mainly due to the fact that an administrative offence as a formal offence (material consequences is not a prerequisite of an offence) is illegal and punishable irrespective of the form of person's mental attitude towards the offence. The importance of fault as a mental attitude has been even more diminished since the introduction of administrative liability towards legal entities. In other areas of administrative law (competition and finance law) the notion of fault has no relevance, as well.

2. However, the fault as a legal notion in administrative offence law still should be used to describe the link between the activity or inactivity and a person who commits those acts. In this regard, the fault has two elements - objective and subjective one. The objective element is the fact that the activity or inactivity is attributable to a particular person. The subjective element is the fact that the person was capable of understanding his behavior (sanity) and that there are no other facts that exclude the possibility to punish the offender (force majeure, excusable mistake, etc.).

3. Fault should be understood not as a special and mandatory prerequisite of administrative liability but rather as a set of facts (absence of facts) that enables to conclude that the offence has been committed by a particular person and that there are no legally justifiable excuses that prevent administrative liability.

\section{BIBLIOGRAPHY}

\section{Literature}

1. Briede J., Danovskis E., Kovalı̧evska A. Administratīvās tiesības. Mācību grāmata. Rìga: Tiesu namu aǵentūra, 2016.

2. Krastiņš U. Noziedzīga nodarījuma sastāvs un nodarījuma kvalifikācija. Teorētiskie aspekti. Rīga: Tiesu namu aǵentūra, 2014.

3. Panebianco G. The Nulla Poena Sine Culpa Principle in European Courts Case Law. In: Human Rights in European Criminal Law. New Developments in European Legislation and Case Law after the Lisbon Treaty. Springer, 2015, pp. 47-78.

4. Rozenbergs J. Vainas institūts krimināltiesībās un tā nozīme noziedzīgu nodarījumu kvalifikācijā. Promocijas darbs. Rīga: Latvijas Universitāte, 2012, pp. 20-21. Available at https://dspace.lu.lv/dspace/bitstream/handle/7/5122/22890-Janis_Rozenbergs_2012. pdf? sequence $=1$ \&isAllowed $=y$ [last viewed August 8, 2016].

\section{Legislative acts}

1. Council Regulation No 1/2003 of 16 December 2002 on the implementation of the rules on competition laid down in Articles 81 and 82 of the Treaty. Official Journal. 2003. 4. January, L 001. 
2. Administratīvo pārkāpumu procesa likums (likumprojekts). Available at http://titania.saeima. lv/LIVS11/saeimalivs11.nsf/0/C09FFF1B23A17044C2257CDF0023B6DA?OpenDocume nt [last viewed August 30, 2016].

3. Grozījumi Latvijas Administratīvo pārkāpumu kodeksā. Latvijas Vēstnesis. 1998. 8. jūlijs, Nr. 199/200.

4. Konkurences likums. Latvijas Vēstnesis. 2001. 23. oktobris, Nr. 151 (2538).

5. Kredītiestāžu likums. Latvijas Vēstnesis. 1995. 24. oktobris, Nr. 163 (446).

6. Latvijas Administratīvo pārkāpumu kodekss. Ziṇotājs, 1984. 20. decembris, Nr. 51.

\section{Legal practice}

1. Judgment of the European Court of Human Rights of 7 October 1988 in case Salabiaku v. France.

2. Judgment of the Grand Chamber of the European Court of Justice of 18 June 2013 in case No. C-681/11 Shenker \& Co. AG et al. 
Vadim Mantrov, Dr. iur.

University of Latvia, Latvia

\title{
REGULATION OF RECOURSE CLAIM GROUNDS IN LATVIAN MOTOR INSURANCE LAW
}

\begin{abstract}
Summary
One of the most important, yet little studied aspects of Latvian motor insurance law relates to regulation of grounds for bringing a recourse claim by an insurer (a national insurers' bureau) and its critical evaluation. Recourse claim grounds in motor insurance law are subject to specific regulation considering special character of relationships arising from damage caused in the result of road traffic accidents and fulfilment of a motor insurance contract. At the same time, regulation of recourse claim grounds shall not become formalistic or unjustified, as this regulation should comply with the principle of justice as a general legal principle and the principle of effectiveness of EU motor insurance law. This article explores regulation of recourse claim grounds in Latvian motor insurance law by identifying recourse claim grounds that could be viewed as complying with those two principles and those who are not due to their formal and unjustified character. Since separate recourse claim grounds are considered formal and contrary to both of the above principles, the author, consequently, suggests solutions for elimination of these shortcomings by offering legislative proposals for Latvian motor insurance law.
\end{abstract}

Keywords: motor insurance law, recourse claim, recourse claim grounds, subrogation, public interest, principle of justice, principle of effectiveness.

\section{Introduction}

Regulation of recourse claim - or subrogation claim, as it is usually referred to in common law countries ${ }^{1}$ - is an important part of insurance law. ${ }^{2}$ Particularly, the list of recourse claim grounds and exceptions is an essential element of that regulation when an insurer may bring a recourse claim against a person liable for causing damage, which was the basis for providing insurance redress to an insured (victim,

1 See, for instance, the publications and respective pages cited in next two references. It should be taken into account, however, that subrogation is recognised in different continental European countries yet from the point of view of its different perception and regulation.

2 For general discussion of recourse (subrogation) claim in insurance law from the common law perspective, see, for instance, Jerry R. H., II, Richmond D. R. Understanding insurance law. Fourth ed. LexisNexis, 2007, pp. 676-708 (concerning USA); Clarke M. A., Burling J. M., Purves R. L. The Law of Insurance Contracts, Sixth edition. London: Informa, 2009, pp. 1021 et seq. or Merkin R. Colinvaux's Law of Insurance. $8^{\text {th }}$ ed. London: Sweet \& Maxwell, 2006, pp. 379-407 (concerning the UK); from the European perspective, see Basedow J., Birds J., Clarke M., Cousy H., Heiss H. (eds.). Principles of European Insurance Contract Law (PEICL). Munich: Sellier.European law publishers, 2009, pp. 255-260. For critical evaluation of subrogation from recent insurance law literature, see Merkin R., Steele J. Insurance and the Law of obligations. Oxford: Oxford University Press, 2013, pp. 97-137. 
beneficiary). ${ }^{3}$ At the same time, recourse claim grounds that could be invoked by insurers (or national insurers' bureaux), in motor insurance law is usually subject to special regulation, considering specifics of a motor insurance contract in conjunction with legal relationships arising from damage caused in the result of road traffic accidents.

Regulation of recourse claim grounds in Latvian motor insurance law is explored in limited extent so far. At the same time, Latvian legal scholars have discussed Latvian motor insurance law in general ${ }^{4}$ and considered recourse claim grounds in Latvian motor insurance law, ${ }^{5}$ yet critical evaluation of recourse claim grounds in Latvian motor insurance law has remained limited in its extent. ${ }^{6}$ Similarly, the competence of EU Member States to provide regulation of recourse claim grounds in EU motor insurance law is little studied in European legal literature.

The aim of this article is to explore regulation of recourse claim grounds specifically in Latvian motor insurance law in comparison with other EU Member States. Therefore, this article would continue the research of recourse (subrogation) claim regulation in Latvian insurance law, whose discussion in general was carried out previously by the author of these lines. ${ }^{7}$ The structure of this article is, as follows: at the beginning, two legal principles underlying regulation of recourse claim grounds would be explored, particularly the principle of justice being one of general legal principles and the principle of effectiveness being a specific principle of EU motor insurance law; afterwards, Latvian regulation of recourse claim grounds in motor insurance law would be examined in conjuncture with approaches of other EU Member States; and, finally, conclusions will be provided for eliminating shortcomings of the existing Latvian motor insurance law concerning regulation of recourse claim grounds.

Before turning to discussion of recourse claim grounds' regulation in conjunction with the approaches of other EU Member States, a reservation should be retained in relation to the use of the comparative method. Due to the scope of this article, the comparison of recourse claim grounds in different EU Member States in this article is limited only to these grounds themselves, at the same time, considering the existing differences between EU Member States concerning regulation of recourse claim grounds as such. On the one hand, there are EU Member States, which admit subrogation in their general law of obligations (either generally, like

3 For the twofold function of recourse (subrogation) claim, see Clarke M. Policies and Perceptions of Insurance: An Introduction to Insurance Law. Oxford: Clarendon Press, 1997, pp. 253-254; Jerry R. H., II, Richmond D. R. Understanding insurance law. Fourth ed. LexisNexis, 2007, pp. 678-679; Mehr I. R., Cammack E., Rose T. Principles of Insurance. Eighth edition. Homewood, Illinois: Richard D. Irwin, Inc., 1985, p. 141.

4 Torgāns K. Saistību tiesības. Mācību grāmata. R.: Tiesu namu aǵentūra, 2014, pp. 453-455.

5 Torgāns K. Saistību tiesības. Mācību grāmata. R.: Tiesu namu ağentūra, 2014, pp. 456-458.

6 Torgāns K. Regresa prasība OCTA apdrošināšanā. Grām.: Torgāns K. Civiltiesību, komerctiesību un civilprocesa aktualitātes. Raksti 1999.-2008. Kalvis Torgans. Current Topics on Civil, Commercial and Civilm Procedure. Selected articles 1999-2008. R.: Tiesu namu agentūra, 2009, pp. 567-583.

Mantrovs V. Regresa prasības regulējums Latvijas apdrošināšanas tiesībās. Grām.: Ārvalsts investīcijas: kad tiesības mijiedarbojas. Latvijas Universitātes 74. zinātniskās konferences rakstu krājums. R.: LU Akadēmiskais apgāds, 2016, pp. 408-419. 
in France, or as a special case of subrogation concerning insurance, as in Italy ${ }^{8}$; on the other, there are EU Member States like Latvia, Estonia or Germany, which do not recognise subrogation in their general law of obligations. ${ }^{9}$ Likewise, there are considerable differences for regulation of recourse claim in general among EU Member States. ${ }^{10}$ In addition, there are EU Member States, which provide exclusive lists of recourse claim grounds like Baltic States, as it will be discussed further, but there are also EU Member States like Spain, which do not have such an exclusive list, and even Member States, which do not have any statutory list of recourse claim grounds.

\section{Principles governing recourse claim grounds in motor insurance law}

Regulation of recourse claim grounds in Latvian (like in the case of other EU Member States) motor insurance law may be considered from the perspective of two principles: the principle of justice, which underlines the continental European legal system, being one of general legal principles, and the principle of effectiveness, which characterises the nature of EU motor insurance law.

\subsection{The principle of justice}

The aim of recourse claim in motor insurance law remains identical to the case of general regulation of insurance law. From the point of view of insurance economics, recourse claim could be explained in terms of distribution of losses among the members of entire society and diminution of losses by insurers. But, as far as regulation of recourse claim is covered, the necessity of ensuring justice is at the heart of regulation of recourse claim in insurance law in general and motor insurance law in particular. In this regard, one may refer to Ulpian, one of the most famous Ancient Rome lawyers, who, by referring to Celsius, wrote that ius est ars boni et aequi. ${ }^{11}$ Similarly, the Institutiones was based on the understanding that iuris prudentia est [..] iusti atque iniusti scientia. ${ }^{12}$ Therefore, it is not a coincidence that, by justifying recourse claim regulation either in general or particularly in motor insurance, insurance law commentators either referred to public interest ${ }^{13}$ or justice

8 Art. 1916 (1) Italian Civil Code, available at http://www.jus.unitn.it/cardozo/obiter_dictum/ codciv/ Codciv.htm [last viewed March 8, 2017]. For discussion of the right of subrogation in Italian insurance law, see Cerini D. Insurance Law in Italy. AH Alphen aan den Rijn: Kluwer Law International, 2012, pp. 100-101, 126-127.

9 Mantrovs V. Regresa prasības regulējums Latvijas apdrošināšanas tiesībās. Grām.: Ārvalsts investīcijas: kad tiesības mijiedarbojas. Latvijas Universitātes 74. zinātniskās konferences rakstu krājums. R.: LU Akadēmiskais apgāds, 2016, pp. 408-419.

10 Ibid.

11 D. $1,1,1$.

12 I. $1,1,1$.

13 Mehr I. R., Cammack E., Rose T. Principles of Insurance. Eighth edition. Homewood, Illinois: Richard D. Irwin, Inc., 1985, p. 141. 
as the cornerstone of recourse claim regulation. Indeed, as Prof. Robert H. Jerry, II and his co-author write, "subrogation is intended to work justice, and a just result is having the loss fall ultimately on the party legally responsible for it". "At the same time, the right of subrogation and, consequently, recourse claim grounds are linked with the good faith principle. If in Europe this link is presumed, then in common law it is one of requirements for exploitation of a right of subrogation: if in the case of the USA it is admitted expressis verbis ${ }^{15}$ then in case of the UK it is referred to acting "in good faith in proceeding against the third party" 16 as well as public policy serving as a substantiation, when the right of subrogation may be refused. ${ }^{17}$

\subsection{The principle of effectiveness}

Another principle - the principle of effectiveness - underlying regulation of recourse claim grounds comes from EU motor insurance law.

EU motor insurance law is neither fully approximated (coordinated) like other insurance law branches in particular and civil law branches in general, ${ }^{18}$ nor it is perceived as exhaustive in difference from certain directives in the field of EU consumer law. ${ }^{19}$ One of such fragmentarily approximated aspects in EU motor insurance law relates to recourse claim grounds to be employed by insurers (national insurers' bureaux) against persons who have caused damage as a result of road traffic accidents, which have taken place within the territory of EU Member States (as far as EU motor insurance law is concerned). Though fragmentary regulation of recourse claim (subrogation) is provided by EU motor insurance law, the list of recourse claim grounds are neither clearly nor exhaustively regulated.

Initially, EU motor insurance law did not provide any specific regulation in respect of recourse claim (subrogation) or its grounds. So, the First $\mathrm{MID}^{20}$ dealt with this issue neither in the initial nor its amended wording. Yet, already the First MID envisaged the principle of separateness in motor insurance being a type of civil liability insurance. The principle of separateness was undoubtedly provided by

${ }^{14}$ Jerry R. H., II, Richmond D.R. Understanding insurance law. Fourth ed. LexisNexis, 2007, pp. 679 (see also p. 680 concerning preconditions of subrogation claim yet solely from the American perspective).

15 Ibid., p. 680.

16 Merkin R. Colinvaux's Law of Insurance. $8^{\text {th }}$ ed. London: Sweet \& Maxwell, 2006, p. 379.

17 Clarke M. A., Burling J. M., Purves R. L. The Law of Insurance Contracts, Sixth edition. London: Informa, 2009, pp. 1050-1051.

18 For comprehensive discussion of regulation of civil (private) law at the level of EU law, see Bernitz U., Groussot Z., Schuylok F. General principles of European Union law and European private law. Alphen aan den Rijn, The Netherlands: Kluwer Law International, 2013.

19 For the concept of an exhaustive directive in EU consumer law, see, for instance, Micklitz H.-W., Reich N., Rott P. EU consumer law, $2^{\text {nd }}$ ed. Antwerpen, Portland: Intersentia, 2014.

20 Council Directive 72/166/EEC of 24 April 1972 on the approximation of the laws of Member States relating to insurance against civil liability in respect of the use of motor vehicles, and to the enforcement of the obligation to insure against such liability. OJ, L 103, 02.05.1972., pp. 1-4. English special edition, series I, Vol. 1972(II), pp. 360-362 [First MID]. 
Article 3 (1) of the First MID, and currently included in a corresponding provision ${ }^{21}$ in the currently effective CMID. ${ }^{22}$ EU Member States have not had free hands to legislate on civil liability regulation in respect of compensation of damage caused in road traffic accidents including regulation of recourse claim grounds. Specifically, EU Member States are bound by the principle of effectiveness of EU motor insurance law recognised and applied by the CJEU consistently since the decision in Ruiz Bernaldez case ${ }^{23}$ twenty years ago, i.e. in 1996.

However, an unresolved problem question still remains: how to apply that principle in specific situations, for instance, in relation to recourse claim grounds. So far, the CJEU has provided answers to different situations for application of the principle of separateness, however, no single situation has related to recourse claim grounds. Such a situation brings uncertainty about criteria for assessment of regulation of recourse claim grounds in national motor insurance law of EU Member States from the perspective of the principle of effectiveness of EU motor insurance law. Particularly, there could be occasions, when insured liable motor vehicle drivers are in the situation that insurers may claim their civil liability for causing a road traffic accident and, consequently, raise a recourse claim against them despite their insurance coverage. It must be emphasised that EU motor insurance law provides, among its aims, that regulation of motor insurance is "of special importance for European citizens, whether they are policyholders or victims of an accident" and "a major concern for insurance undertakings as it constitutes an important part of non-life insurance business in the Community". ${ }^{4}$ This aim is especially important in the case of recourse claim grounds, as it involves protection of interests of both insurers concerning their rights to invoke recourse claim grounds, on the one hand, and those insured, as well as other participants of road traffic, on the other, who may be faced with such claims and, therefore, are interested to escape or limit the recourse claim grounds.

When the Fourth $\mathrm{MID}^{25}$ was adopted, the first, yet incomplete and fragmentary, regulation on recourse claim appeared in EU motor insurance law. This regulation was left unchanged by the Fifth MID ${ }^{26}$, in particular its Article 5, and later codified in

${ }^{21}$ Art. 3 first and second subparagraphs, CMID.

22 Directive 2009/103/EC of the European Parliament and of the Council of 16 September 2009 relating to insurance against civil liability in respect of the use of motor vehicles, and the enforcement of the obligation to insure against such liability. OJ, L 263, 07.10.2009., pp. 11-31 [Codifying Motor Insurance Directive or CMID].

23 Case No. C-129/94 Criminal proceedings against Rafael Ruiz Bernáldez [1996] ECR I-01829 Ruiz Bernaldez.

24 CMID, preamble, para. 2.

25 Directive 2000/26/EC of the European Parliament and of the Council of 16 May 2000 on the approximation of the laws of the Member States relating to insurance against civil liability in respect of the use of motor vehicles and amending Council Directives 73/239/EEC and 88/357/ EEC (Fourth motor insurance Directive). OJ, L 181, 20.07.2000., pp. 65-74 [Fourth MID].

26 Directive 2005/14/EC of the European Parliament and of the Council of 11 May 2005 amending Council Directives 72/166/EEC, 84/5/EEC, 88/357/EEC and 90/232/EEC and Directive 2000/26/EC of the European Parliament and of the Council relating to insurance against civil liability in respect of the use of motor vehicles. OJ, L 149, 11.06.2005., pp. 14-21 [Fifth MID]. 
the un-amended wording by the CMID. Specifically, the Fourth MID, firstly, admitted the possibility of recourse claim in EU motor insurance law, which was an evident issue due to longstanding and extensive practice of recourse (subrogation) claim in EU Member States ${ }^{27}$ and, secondly, provided a limitation and a substantiation for a recourse claim to be brought by compensation bodies ${ }^{28}$ established by the Fourth MID itself. ${ }^{29}$

However, neither five motor insurance directives nor the CMID provides the list of recourse claim grounds to be used by insurers against liable persons, including liable motor vehicle drivers being completely un-harmonised issue except the application of the principle of effectiveness of EU motor insurance law and regulation of recourse claim in respect to compensation bodies. If this situation is compared, for instance, with the grounds on which insurance redress may be refused, then the situation in case of the latter is different. By being aware of different practices among EU (than EEC) Member States, the European legislator provided for a nonexhaustive list of such grounds in 1984, when the Second MID was adopted. These grounds were included in Article 2 (1) of the Second MID. ${ }^{30}$ All these grounds were based on an assumption that insurance redress shall be provided irrespectively of the conduct of victims, except if persons who voluntarily entered the vehicle, which caused the damage or injury, was stolen and they knew that. ${ }^{31}$ Otherwise, application of EU motor insurance law would become meaningless and ineffective, i.e., contrary to the principle of effectiveness, as it would not provide a sufficient protection to victims of road traffic accidents. ${ }^{32}$

Therefore, recourse claim grounds as provided by national law of EU Member States could not be formal, unjustifiably shifting burden of loss from an insurer or a national motor insurers' bureau to a liable insured motor vehicle driver or its owner. These criteria, consequently, should be used for evaluation of recourse claim grounds as provided in Latvian motor insurance law.

\section{The Latvian regulation of recourse claim grounds}

Regulation of recourse claim grounds in Latvian motor insurance law is provided by Article 41 of the Compulsory Civil Liability Insurance of Owners of Motor Vehicles $\mathrm{Act}^{33}$ (Latvian Motor Insurance Act). This regulation provides the exhaustive

27 Fourth MID, preamble, para. 27 (now CMID, preamble, para. 49).

28 Fourth MID, preamble, paras. 27-28, Art. 6 (2) (now CMID, preamble, paras. 49-50, Art. 24 (2).

29 Art. 6 Fourth MID (now Art. 24 CMID).

30 Now Art. 13 (1) CMID.

31 Art. 13 (1) third sub-paragraph CMID.

32 Cf. Case No. C-129/94 Criminal proceedings against Rafael Ruiz Bernáldez [1996] ECR I-01829 Ruiz Bernaldez, para. 19.

33 Sauszemes transportlīdzekḷu īpašnieku civiltiesiskās atbildības obligātās apdrošināšanas likums: LR likums. Latvijas Vēstnesis, 2004. 27. aprïlis, Nr. 65. English text available at http://www.vvc.gov.lv/ export/sites/default/docs/LRTA/Likumi/Compulsory_Civil_Liability_Insurance.doc [last viewed March 8, 2017]. 
list (numerus clausus) of claimants and defendants that may either bring or face a recourse claim and, in addition, the exhaustive list of grounds, which shall be employed as grounds for a recourse claim against each of defendants included in the former list. This regulation is considered as special law (lex specialis) in relation to general regulation of recourse claim ${ }^{34}$ included in regulation of insurance contracts (Articles 40 of the Latvian Insurance Contract $\mathrm{Act}^{35}$ ) and fully replaces the latter regulation in relation to recourse claim grounds. At the same time, this special regulation included in the former Act does not replace all the issues regulated under general regulation of recourse claim, for instance, the prescription period included in Article 40 (8) of the Latvian Insurance Contract Act) is not amended neither by Article 41 nor any other provision in the Latvian Motor Insurance Act. Consequently, as it was interpreted by Latvian courts, that prescription period applies to recourse claims brought on the grounds exhaustively provided by Article 41 of the Latvian Motor Insurance Act.

Similarly to the case of other EU Member States, a recourse claim may be brought either by an insurer who concluded a motor insurance contract and provided insurance redress to a victim of a road traffic accident or a Latvian motor insurers' bureau who supplied insurance redress to that victim, if a liable motor vehicle driver was either un-insured or un-identified. A recourse claim on certain grounds to be discussed below may be brought by an insurer or a national insurers' bureau against certain defendants, whose list is exhaustively and casuistically regulated: either against a liable motor vehicle driver; against a motor vehicle owner or - in the case of leasing - against a leasing taker; a road owner (manager); a person who caused damages with wilful intention; and against a merchant, who sells motor vehicles, if it allowed a motor vehicle to be involved in road traffic. These grounds will be discussed further by differentiating them from the point of view of a possible defendant.

Based on the discussion carried out in Chapter II above, regulation of recourse claim grounds laid down by Article 41 of the Latvian Motor Insurance Act is subject to the principle of justice and the principle of effectiveness. Considering specifics of a motor insurance contract and relationships arising from this contract in conjunction with liability arising from road traffic accidents, the operation force of both principles means that recourse claim grounds in motor insurance law should be linked with one of two situations:

1) increase of probability of occurrence of the risks insured either at the moment (such as intoxication, intent, inappropriate conditions of a motor vehicle) or after a road traffic accident (intoxication immediately after that accident); or

2) increase of the amount of damages resulting from the road traffic accident caused to the insurer (the national insurer' bureau) by illegal activity of

${ }^{34}$ For its discussion, see Mantrovs V. Regresa prasības regulējums Latvijas apdrošināšanas tiesībās. Grām.: Ārvalsts investīcijas: kad tiesības mijiedarbojas. Latvijas Universitātes 74. zinātniskās konferences rakstu krājums. R.: LU Akadēmiskais apgāds, 2016, pp. 408-419.

35 Par apdrošināšanas lịgumu: LR likums. Latvijas Vēstnesis, 1998. 30. jūnijs, Nr. 188/189. English text available at http://www.vvc.gov.lv/export/sites/default/docs/LRTA/Likumi/On_Insurance_ Contracts.doc [last viewed March 8, 2017]. 
a liable motor vehicle driver or its owner (lessee or, if applicable, another lawful user).

Recourse claim grounds will be considered further from both of these perspectives.

\subsection{Recourse claim grounds in recourse claims brought by an insurer}

\subsubsection{Recourse claim grounds against a liable motor vehicle driver}

A recourse claim against a liable motor vehicle driver may be brought, based on any of the five recourse claim grounds provided by Article 41 (1) (1) of the Latvian Motor Insurance Act, such as:

1) driving under intoxication;

2) driving without permit;

3) performing certain inappropriate activities after a road traffic accident such as leaving a road traffic accident scene, intoxication, or refusal to pass intoxication test;

4) failure either to submit an agreed statement in procedure prescribed by law ${ }^{36}$ or provide information about conditions of the road traffic accident to an insurer if the circumstances of the road traffic accident have been recorded by the state police;

5) causing damages by a wilful criminal offence.

This list of recourse claim grounds shows that any of these grounds could be invoked against every liable motor vehicle driver, if the respective conditions as provided in a particular recourse claim ground are satisfied.

Recourse claim grounds No. 1 to 3 are based on a link between conditions that could increase probability of occurrence of the insured risks, either because of the loss of care due to intoxication (recourse claim ground No. 1), possibility of such an intoxication (recourse claim ground No. 3) or a lack of opportunity to check the driving abilities (recourse claim ground No. 2). It is not, therefore, a coincidence that these recourse claim grounds are provided by national law of other EU Member States like Spain ${ }^{37}$ or Latvian neighbouring countries like Estonia ${ }^{38}$ and Lithuania. ${ }^{39}$

36 An agreed statement shall be submitted within 10 days after the day of the occurrence of the road traffic accident where the circumstances of the road traffic accident have been recorded using the agreed statement forms (Art. 36 (2) (2) Latvian Motor Insurance Act).

37 Art. 10 (a) and (c) Spanish Motor Insurance Act (Real Decreto Legislativo 8/2004, de 29 de octubre, por el que se aprueba el texto refundido de la Ley sobre responsabilidad civil y seguro en la circulación de vehículos a motor. Available at http://noticias.juridicas.com/base_datos/Privado/ rdleg8-2004.html [last viewed March 8, 2017].

38 Arts. 53 (1) (2) and (4), 53 (2) (3) - (4) Estonian Motor Insurance Act. Available at https://www. riigiteataja.ee/en/eli/506012015001/consolide [last viewed March 8, 2017].

39 Art. 22 (1) (1), (3) and (4) Lithuanian Act on Compulsory Insurance Against Civil Liability in Respect of the Use of Motor Vehicles [Lithuanian Motor Insurance Act]. Available at http://www. cab.lt/index.php/en/pages/view/?item_id=23 [last viewed March 8, 2017]. 
Likewise, on the basis of Article 151 of the Road Traffic Act $1988^{40}$ an UK insurer may exploit a recourse claim (right of recourse) against an insured, if the insurer shall fulfil the motor insurance contract despite contractual defences ${ }^{41}$ considering the fact that the right of subrogation precludes an action against the insured (coinsured)..$^{42}$ Similarly, Italian insurance law provides that the insured is responsible to the insurer of the injury caused to the right of subrogation. ${ }^{43}$

Therefore, one may not concur with the opinion that there are no indications in foreign insurance motor insurance law that a recourse claim is possible against an insured motor vehicle driver. ${ }^{44}$

Furthermore, the recourse claim ground No. 4 could be employed by an insurer only if a liable motor vehicle driver caused damages to the insurer due to his or her omission but not formally just based on the fact that he or she did not submit an agreed statement or other documents, whose content the insurer could find out independently. Such position would be in line with the national law of other EU Member States, for instance, Lithuanian motor insurance law, which allows a recourse claim on that ground only if such breach resulted in an increase of damage to the insurer through the fault of the motor vehicle driver; ${ }^{45}$ or within German motor insurance law, where the insurer may demand only additional amount to be paid due to that breach (in case of either intent or gross negligence). ${ }^{46}$

However, there is evidence that Latvian courts apply these recourse claim grounds formalistically, just on the basis of the fact that an agreed statement was not submitted to the insurer within 10 days from the moment of a road traffic accident ${ }^{47}$ Indeed, as far as Latvian court judgments available within the online anonymous Latvian court practice data base are discussed, Latvian courts satisfy a recourse claim brought on the basis of this recourse claim ground, if it is established that an agreed statement

40 Art. 151 (7) - (8) Road Traffic Act 1988. Available at http://www.legislation.gov.uk/ ukpga/1988/52/contents [last viewed March 8, 2017].

${ }^{41}$ For its discussion, see Clarke M. A., Burling J. M., Purves R. L. The Law of Insurance Contracts, Sixth edition. London: Informa, 2009; pp. 222-223; Merkin R. Colinvaux's Law of Insurance. $8^{\text {th }}$ ed. London: Sweet \& Maxwell, 2006, pp. 396-401.

42 Clarke M. A., Burling J. M., Purves R. L. The Law of Insurance Contracts, Sixth edition. London: Informa, 2009; pp. 1044-1050; Merkin R. Colinvaux's Law of Insurance. $8^{\text {th }}$ ed. London: Sweet \& Maxwell, 2006, pp. 800-801.

43 Art. 1916 (3) Italian Civil Code.

44 Torgāns K. Regresa prasība OCTA apdrošināšanā. Grām.: Torgāns K. Civiltiesību, komerctiesību un civilprocesa aktualitātes. Raksti 1999.-2008. Kalvis Torgans. Current Topics on Civil, Commercial and Civilm Procedure. Selected Articles 1999-2008. R.: Tiesu namu aǵentūra, 2009, 579 p.

45 Art. 22 (2) Lithuanian Motor Insurance Act.

46 Rümenapp M. Kraftfahrzeug-Haftpflichtversicherung, in K. Höra (Hrsg.) Münchener Anwaltshandbuch Versicherungsrecht. 3., überarbeitet und erweiterte Auflage. München: Verlag C.H. Beck, 2013, S. 691; Arbeitsgruppe Bedingungen der Kommission Kraftfahrt Betrieb (KKB). Allgemeine Bedingungen für die Kfz-Versicherung AKB 2008 - Stand 09.07.2008, E.6.6. Available at http://www.assurances.de/pdf/AKB.pdf [last viewed March 8, 2017].

47 Mantrovs V. ar Augstākās tiesas Judikatūras un zinātniski analīiskās nodaḷas informatìvo atbalstu. Augstākās tiesas Civillietu departamenta prakse sauszemes transportlīdzekḷu vadītāju civiltiesiskās atbildības obligāatās apdrošināšanas (OCTA) lietās. R., 2015, 43. lpp. Available at www.at.gov.lv [last viewed March 8, 2017]. 
was not submitted within the 10-day period to the insurer without carrying out any assessment of damage caused to the insurer by such an omission. ${ }^{48}$ Likewise, Latvian courts even refused any consideration of damage that could be caused to the insurer by that omission. For instance, a first instance court refused objections of the defendant - a liable motor vehicle driver - to consider whether any damage was caused to the insurer by failure to submit the agreed statement, indicating that a court should not take into account the preconditions of civil liability, if a recourse claim is brought on the basis of a special legal norm of the Latvian Motor Insurance Act. ${ }^{49}$ Yet, in one case a first instance court acted differently and questioned the possibility to invoke this recourse claim ground just on the basis of formal infringement, i.e. not submitting an agreed statement to the insurer within the prescribed 10 days period when no damage was made to the insurer by that omission. In this case, the first instance court refused the recourse claim brought by the insurer by indicating that an omission to submit an agreed statement "did not influence the adoption of the decision for making insurance payment". This first instance court judgment was annulled by the Civil Case Panel of the Supreme Court by stating that "a motor vehicle driver involved in a road traffic accident shall act so [i.e. he or she shall submit the agreed statement within 10 days - V.M.] as to ensure the insurer with timely information about occurrence of the insured event and ability to involve further in conducted actions". ${ }^{50}$ Therefore, the Supreme Court considered that a recourse claim could be brought on the basis of the discussed recourse claim ground No. 4, irrespectively of whether any damage is caused to the insurer due to non-submission of an agreed statement within the prescribed period of time or not.

Finally, the last recourse claim ground is applicable in wilful criminal offence cases, which are related to criminal liability and not civil liability, whereto the motor insurance adheres. Therefore, this ground is formal, as it provides for a punishment without any link with occurrence of the risks insured. This discussed recourse claim ground is similar to another recourse claim ground linked with an intent falling within civil liability to be discussed below in Section 3.1.3.

\subsubsection{Recourse claim grounds against a motor vehicle owner (a lessee)}

The Latvian Motor Insurance Act provides five recourse claim grounds, based on which an insurer may bring a recourse claim against a motor vehicle owner (a lessee), which are, as follows:

1) non-payment of insurance premium;

48 From recent court practice, it could be mentioned, for instance, Judgment of Riga Regional Court in Case No. C33396014 (not appealed, entered into force on 22 April 2015); Judgment of Zemgale Regional Court of 04 September 2015 in Case No. C31310614 (not appealed, entered into force on 04 September 2015).

49 Judgment of Valmiera district court of 14 April 2014 in Case No. C39102513 (not appealed, entered into force on 20 May 2014).

s0 Judgment of the Civil Case Panel of the Supreme Court of the Republic of Latvia of 31 August 2016 in Case No. SKC-299-16. 
2) failure to submit an agreed statement in accordance with that Act or failure to provide information regarding the circumstances of the road traffic accident to the insurer and the recovery of the loss from the driver of the motor vehicle is not possible;

3) failure to establish a particular motor vehicle driver if a motor vehicle driver has left the scene of a road traffic accident;

4) failure to undergo a State technical inspection on a condition that 'the loss caused in a road traffic accident is causally related to the technical condition of the motor vehicle';

5) failure to fit a motor vehicle with appropriate tyres.

As it could be seen from this list of recourse claim grounds, the last three grounds, as well as the second possibility in the second ground are related to increased probability that the insured risks could occur in accordance with a motor insurance contract, or difficulty with evaluation of damages to be compensated by an insurer. However, the first recourse claim ground and the first possibility in the second recourse claim ground are formalistic, as they are not related to the increase in the probability of the insured risk occurrence. Therefore, the latter two recourse claim grounds exceed the protection of legitimate interests of insurers and do not correspond to the principle of justice and the principle of effectiveness.

As regards non-payment of insurance premium as a recourse claim ground, as opposed to the situation in Latvia, the national law of other EU Member States, for instance, Estonian motor insurance law, tends to limit compensation to be recovered by using the maximum compensation sum that could be comparable with the amount of insurance premium itself ${ }^{\mathrm{f}}$ or, as it is in the case of Lithuania, limit reimbursement of compensation paid to a policyholder. ${ }^{52}$ Such an attitude of the Lithuanian and Estonian motor insurance law is justified, as it links compensation available to the insurer with the amount of insurance premium but not have formal character and, therefore, unjustifiable punishment of a motor vehicle owner (lessee) due to non-fulfilment of a motor insurance contract by failing to cover insurance premium. Similarly, in Spain, an insurer cannot bring a recourse claim against the insured, unless he or she is liable for damage caused to the insurer due to his or her acts or omissions, ${ }^{53}$ which obviously could not exceed the unpaid amount of insurance premium.

For the sake of truth, it should be noted that a similar situation concerning a recourse claim ground due to non-payment of insurance premium exists in Germany, ${ }^{54}$ as

51 Art. 53 (4) Estonian Motor Insurance Act.

52 Art. 11 (7) Lithuanian Motor Insurance Act.

53 Art. 10 (c) Spanish Motor Insurance Act in conjuncture with Art. 43 (2) Spanish Insurance Contract Act (Ley 50/1980, de 8 de octubre, de Contrato de Seguro. Available at http://noticias.juridicas. com/base_datos/Privado/150-1980.html [last viewed March 8, 2017]).

54 For regulation of recourse claim in German motor insurance law, see, for instance, Rümenapp M. Kraftfahrzeug-Haftpflichtversicherung, in K. Höra (Hrsg.) Münchener Anwaltshandbuch Versicherungsrecht. 3., überarbeitet und erweiterte Auflage. München: Verlag C.H. Beck, 2013, S. 690-692. 
in the case of the Latvian Motor Insurance Contract Act discussed above. Yet, in contrast to the Latvian regulation, such recourse claim ground in Germany is linked with peculiarities of German motor insurance law, which connects this recourse claim ground within the damage caused to the insurer by failure to pay insurance premium. Indeed, as the insurer may unilaterally suspend the force of the motor insurance contract due to the non-payment of insurance premium, it cannot use that failure of the policyholder as a justification for non-performance of the motor insurance contract. As victims shall be compensated on the basis of a motor insurance contract without possibility of the insurer to invoke any defence due to non-fulfilment of that contract by other party, i.e. the policyholder, this situation leads to causing damage to the insurer, who could otherwise decline the payment of insurance redress. ${ }^{55}$ At the same time, the Latvian situation is different from the German situation, as, in case of Latvia, the recourse claim ground due to failure to pay insurance premium is completely formal, considering that it is not related to the fact that the insurer is prohibited to use any contractual defences against the victim, as in the case of Germany, but in contrast to Germany, the insurer in Latvia may not unilaterally withdraw from a motor insurance contract due to non-payment of insurance premium, but may only claim the unpaid insurance premium from a policyholder. ${ }^{56}$ In practice, the exploitation of this recourse claim ground leads to obvious injustice and complete misapplication of the indemnity insurance principle in motor insurance cases in Latvia. So, in a recent case heard by Latvian courts, a regional court hearing that case at appeal established that the amount of unpaid insurance premium corresponds to 115,91 euro. However, by satisfying a recourse claim on the basis of the recourse claim ground due to non-payment of insurance premium, a regional court collected from the defendant 40 892,51 euro including the amount of previously paid insurance redress as damages, court expenses and even the unpaid amount of insurance premium. ${ }^{57}$ Therefore, the total amount collected from the owner of a motor vehicle in this case was more than 350 times higher than then amount of the insurance premium itself.

\subsubsection{Recourse claim grounds against other persons}

In the case of recourse claim grounds against persons other than a liable motor vehicle driver or its owner (lessee), the problems characterised above do not appear. If a person has caused damage with intent, civil liability of that person is presumed and, therefore, a recourse claim against such a person is justified. Such ground is available in national law of other EU Member States, yet it either applies to any person like in Lithuania, ${ }^{58}$ or it is limited to a motor vehicle driver, ${ }^{59}$ however, in

\footnotetext{
55 Ibid., S. 691; C. Wagner. Regressansprüche des Kfz-Haftpflichtversicherers. Neue Justiz, 2/2011, S. 45-50.

56 Art. 14 (5) - (6) Latvian Motor Insurance Act.

57 Judgment of Riga Regional Court of 14 December 2015 in Case No. C17147611 (not appealed).

58 Art. 22 (1) (5) Lithuanian Motor Insurance Act.

59 See, for instance, Art. 53 (1) (1) Estonian Motor Insurance Act.
} 
Latvia it applies to any person except the liable insured motor vehicle driver, as interpreted by the Supreme Court of the Republic of Latvia. ${ }^{60}$

A similar conclusion may be arrived at concerning a recourse claim ground against a road owner (manager) or a trading merchant, who is responsible for damage caused, yet such grounds are rarely found in motor insurance law. ${ }^{61}$ In other EU Member States, a recourse claim could be brought against any third party responsible for damage: if, for instance, in Spain it is clearly provided by motor insurance regulation, ${ }^{62}$ in France it arises from the general regulation of subrogation claim grounds. ${ }^{63}$

\subsection{Recourse claim grounds in recourse claims brought by the Latvian national insurers' bureau}

Article 41 (2)-(4) of the Latvian Motor Insurance Act provides different recourse claim grounds to be exploited solely by the Latvian national insurers' bureau. Two of these recourse claim grounds are the most important in practice with regard to persons who are responsible for damage caused as a result of road traffic accidents. Indeed, the Latvian national insurers' bureau may bring a recourse claim against a motor vehicle owner (a lessee or another lawful user), if a motor insurance contract was not concluded, or against a motor vehicle driver, if the motor vehicle was obtained by illegal methods. ${ }^{64}$ However, in the case of the latter recourse claim ground, the Latvian Motor Insurance Act does not explicitly provide that a recourse claim on such a ground could be brought only against a motor vehicle driver, who has obtained the motor vehicle by illegal methods and simultaneously has been liable for causing a road traffic accident, Latvian courts have been guided by that interpretation. ${ }^{65}$ Therefore, both of these grounds relate to the risks insured within a motor insurance contract and, therefore, are justifiable - this conclusion is also

60 Judgment of the Civil Case Panel of the Senate for the Supreme Court of the Republic of Latvia of 18 October 2006 in Case No. SKC-576/2006 (C15091705); Judgment of the Civil Case Panel of the Senate for the Supreme Court of the Republic of Latvia of 28 March 2007 in Case No. SKC-174; see also: Mantrovs V. ar Augstākās tiesas Judikatūras un zinātniski analītiskās nodaḷas informatīvo atbalstu. Augstākās tiesas Civillietu departamenta prakse sauszemes transportlīdzekḷu vadītāju civiltiesiskās atbildības obligātās apdrošināšanas (OCTA) lietās. R., 2015, 44. lpp. Available at www. at.gov.lv [last viewed March 8, 2017].

${ }^{61}$ Such recourse claim grounds are explicitly provided neither in Estonia nor in Lithuania.

62 Art. 10 (b) Spanish Motor Insurance Act.

${ }^{63}$ Art. 1251 (3) French Civil Code (French Civil Code, available at https://www.legifrance.gouv.fr/ content/download/1950/13681/version/3/file/Code_22.pdf [last viewed March 8, 2017]).

64 Art. 41 (2) (1) and (2) Latvian Motor Insurance Act.

${ }_{65}$ From recent court practice, it could be mentioned, for instance, Judgment of Riga city Latgale district court of 13 May 2016 in Case No. C29498515 (not appealed, entered into force on 03 June 2016); Judgment of Riga city Vidzeme district court of 09 May 2016 in Case No. C30607415 (initiation of appeal proceedings was rejected, entered into force on 01 June 2016); Judgment of Rezekne court of 11 February 2016 in Case No. C26140215 (appealed, sustained by appeal court). 
supported by national law of other EU Member States, for instance, Lithuania ${ }^{66}$ or Estonia $^{67}$, who also recognise such recourse claim grounds.

\section{Conclusions}

As regulation of recourse claim grounds shall comply with the principle of justice and shall not deprive effectiveness of EU motor insurance law, this regulation, as provided by Latvian motor insurance law, in some occasions, has come into conflict with these principles. Consequently, the regulation of recourse claim grounds included in the Latvian Motor Insurance Act should be revised and amended, as follows:

1) to abolish the recourse claim ground that enables a recourse claim against a motor vehicle driver, if damages are caused by a wilful criminal offence (Articles 41 (1) (1) (5) of the Latvian Motor Insurance Act);

2) to provide that the recourse claim ground against a motor vehicle driver based on failure either to submit an agreed statement in procedure prescribed by law or provide information about the conditions of the road traffic accident to an insurer is possible, if it increases probability of occurrence of the risks insured or caused damage to the insurer;

3 ) to provide that a recourse claim may be brought against any person including a liable insured motor vehicle driver that caused a road traffic accident with intent;

4) to introduce the maximum amount of a recourse claim, if a recourse claim against a motor vehicle owner (lessee) is brought based on the failure to pay the insurance premium.

Alternatively, regulation of recourse claim grounds included in the Latvian Motor Insurance Act may be interpreted by Latvian courts in the light of the above two principles reaching the same result as would be brought about by adoption of legislative proposals enumerated in the previous paragraph.

\section{BIBLIOGRAPHY}

\section{Literature}

1. Basedow J., Birds J., Clarke M., Cousy H., Heiss H. (eds.). Principles of European Insurance Contract Law (PEICL). Munich: sellier.european law publishers, 2009.

2. Bernitz U., Groussot Z., Schuylok F. General principles of European Union law and European private law. Alphen aan den Rijn, The Netherlands: Kluwer Law International, 2013.

3. Cerini D. Insurance Law in Italy. AH Alphen aan den Rijn: Kluwer Law International, 2012.

4. Clarke M. Policies and Perceptions of Insurance: An Introduction to Insurance Law. Oxford: Clarendon Press, 1997.

${ }^{66}$ Art. 21 (1) (3) Lithuanian Motor Insurance Act.

67 Art. 53 (1) (3) Estonian Motor Insurance Act. 
5. Clarke M. A., Burling J. M., Purves R. L. The Law of Insurance Contracts, $6^{\text {th }}$ ed. London: Informa, 2009.

6. Jerry R. H., II, Richmond D.R. Understanding insurance law. $4^{\text {th }}$ ed. LexisNexis, 2007.

7. Mantrovs V. Regresa prasības regulējums Latvijas apdrošināšanas tiesībās. Grām.: Ārvalsts investīcijas: kad tiesības mijiedarbojas. Latvijas Universitātes 74. zinātniskās konferences rakstu krājums. R.: LU Akadēmiskais apgāds, 2016, pp. 408-419.

8. Mantrovs V. ar Augstākās tiesas Judikatūras un zinātniski analītiskās nodalas informatīvo atbalstu. Augstākās tiesas Civillietu departamenta prakse sauszemes transportlīdzekḷu vadītāju civiltiesiskās atbildības obligātās apdrošināšanas (OCTA) lietās. R., 2015. Available at www. at.gov.lv [last viewed March 8, 2017].

9. Mehr I. R., Cammack E., Rose T. Principles of Insurance. $8^{\text {th }}$ ed. Homewood, Illinois: Richard D. Irwin, Inc., 1985.

10. Merkin R. Colinvaux's Law of Insurance. $8^{\text {th }}$ ed. London: Sweet \& Maxwell, 2006.

11. Merkin R., Steele J. Insurance and the Law of obligations. Oxford: Oxford University Press, 2013.

12. Micklitz H.-W., Reich N., Rott P. EU consumer law, $2^{\text {nd }}$ ed. Antwerpen, Portland: Intersentia, 2014.

13. Rümenapp M. Kraftfahrzeug-Haftpflichtversicherung, in K. Höra (Hrsg.) Münchener Anwaltshandbuch Versicherungsrecht. 3., überarbeitet und erweiterte Auflage. München: Verlag C. H. Beck, 2013.

14. Torgāns K. Saistību tiesības. Mācību grāmata. R.: Tiesu namu aǵentūra, 2014.

15. Torgāns K. Civiltiesību, komerctiesību un civilprocesa aktualitātes. Raksti 1999.-2008. Kalvis Torgans. Current Topics on Civil, Commercial and Civilm Procedure. Selected articles 1999-2008. R.: Tiesu namu aǵentūra, 2009.

16. Wagner C. Regressansprüche des Kfz-Haftpflichtversicherers. Neue Justiz, 2/2011, S. 45-50.

\section{Legislative acts}

1. Council Directive 72/166/EEC of 24 April 1972 on the approximation of the laws of Member States relating to insurance against civil liability in respect of the use of motor vehicles, and to the enforcement of the obligation to insure against such liability. OJ, L 103, 02.05.1972., pp. 1-4. English special edition, series I, Vol. 1972(II), pp. 360-362 [First MID].

2. Directive 2000/26/EC of the European Parliament and of the Council of 16 May 2000 on the approximation of the laws of the Member States relating to insurance against civil liability in respect of the use of motor vehicles and amending Council Directives 73/239/EEC and 88/357/EEC (Fourth motor insurance Directive). OJ, L 181, 20.07.2000., pp. 65-74 [Fourth MID].

3. Directive 2005/14/EC of the European Parliament and of the Council of 11 May 2005 amending Council Directives 72/166/EEC, 84/5/EEC, 88/357/EEC and 90/232/EEC and Directive 2000/26/EC of the European Parliament and of the Council relating to insurance against civil liability in respect of the use of motor vehicles. OJ, L 149, 11.06.2005., pp. 14-21 [Fifth MID].

4. Directive 2009/103/EC of the European Parliament and of the Council of 16 September 2009 relating to insurance against civil liability in respect of the use of motor vehicles, and the enforcement of the obligation to insure against such liability. OJ, L 263, 07.10.2009., pp. 11-31 [Codifying Motor Insurance Directive or CMID]. 
5. Par apdrošināšanas līgumu: LR likums. Latvijas Vēstnesis, 1998. 30. jūnijs, Nr. 188/189. Its English text available at http://www.vvc.gov.lv/export/sites/default/docs/LRTA/Likumi/ On_Insurance_Contracts.doc [last viewed March 8, 2017].

6. Sauszemes transportlīdzekḷu ipašnieku civiltiesiskās atbildības obligātās apdrošināšanas likums: LR likums. Latvijas Vēstnesis, 2004. 27. aprīlis, Nr. 65. English text available at http:// www.vvc.gov.lv/export/sites/default/docs/LRTA/Likumi/Compulsory_Civil_Liability_ Insurance.doc [last viewed March 8, 2017].

7. Arbeitsgruppe Bedingungen der Kommission Kraftfahrt Betrieb (KKB). Allgemeine Bedingungen für die Kfz-Versicherung AKB 2008 - Stand 09.07.2008. Available at http:// www.assurances.de/pdf/AKB.pdf [last viewed March 8, 2017].

8. Estonian Motor Insurance Act.Available at https://www.riigiteataja.ee/en/eli/506012015001/ consolide [last viewed March 8, 2017].

9. French Civil Code. Available at https://www.legifrance.gouv.fr/content/download/1950/ 13681/version/3/file/Code_22.pdf.

10. Italian Civil Code. Available at http://www.jus.unitn.it/cardozo/obiter_dictum/codciv/ Codciv.htm.

11. Lithuanian Act on Compulsory Insurance Against Civil Liability in Respect of the Use of Motor Vehicles [Lithuanian Motor Insurance Act]. Available at http://www.cab.lt/index. $\mathrm{php} / \mathrm{en} / \mathrm{pages} / \mathrm{view} /$ ?item_id=23. \[last viewed March 8, 2017].

12. Road Traffic Act 1988. Available at http://www.legislation.gov.uk/ukpga/1988/52/contents.

13. Spanish Motor Insurance Act (Real Decreto Legislativo 8/2004, de 29 de octubre, por el que se aprueba el texto refundido de la Ley sobre responsabilidad civil y seguro en la circulación de vehículos a motor. Available at http://noticias.juridicas.com/base_datos/Privado/ rdleg8-2004.html [last viewed March 8, 2017]).

14. Spanish Insurance Contract Act (Ley 50/1980, de 8 de octubre, de Contrato de Seguro. Available at http://noticias.juridicas.com/base_datos/Privado/150-1980.html [last viewed March 8, 2017]).

\section{Legal practice}

1. Case No. C-129/94 Criminal proceedings against Rafael Ruiz Bernáldez [1996] ECR I-01829 - Ruiz Bernaldez.

2. Judgment of the Civil Case Panel of the Supreme Court of the Republic of Latvia of 31 August 2016 in Case No. SKC-299-16.

3. Judgment of the Civil Case Panel of the Senate for the Supreme Court of the Republic of Latvia of 28 March 2007 in Case No. SKC-174.

4. Judgment of the Civil Case Panel of the Senate for the Supreme Court of the Republic of Latvia of 18 October 2006 in Case No. SKC-576/2006 (C15091705).

5. Judgment of Riga Regional Court in Case No. C33396014.

6. Judgment of Riga Regional Court of 14 December 2015 in Case No. C17147611.

7. Judgment of Zemgale Regional Court of 04 September 2015 in Case No. C31310614.

8. Judgment of Riga City Latgale District Court of 13 May 2016 in Case No. C29498515.

9. Judgment of Riga City Vidzeme District Court of 09 May 2016 in Case No. C30607415.

10. Judgment of Rezekne Court of 11 February 2016 in Case No. C26140215.

11. Judgment of Valmiera District Court of 14 April 2014 in Case No. C39102513. 
Constitutional Values in Contemporary Legal Space II, 2017

University of Latvia Press

Aspazijas bulv. 5, Riga, Latvia 